\title{
Watershed Characteristics and Water-Quality Trends and Loads in 12 Watersheds in Gwinnett County, Georgia
}

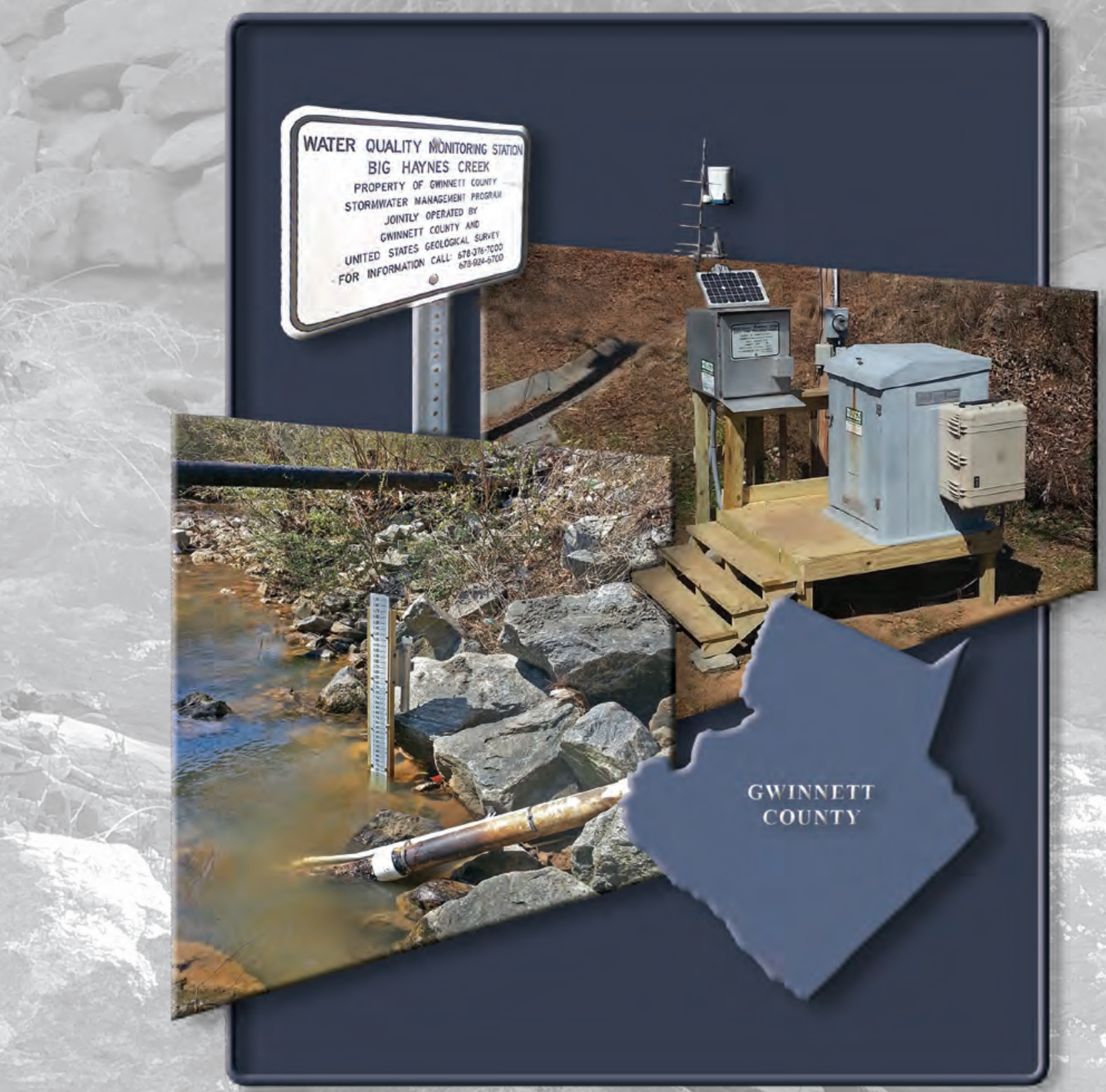

Scientific Investigations Report 2014-5141

U.S. Department of the Interior U.S. Geological Survey 
Cover photographs. Foreground left, staff gage and pipe. The staff gage is an outside measuring point used to confirm/compare with the electronic recording equipment. The water-quality monitor and tubing for the automatic sampler are inside the pipe (by Jonathan Evans, USGS).

Foreground right, gage house and shelter. Inside the metal gage house (left) are the DCP, bubbler, and wiring and recording devices for measuring stage, rainfall, water temperature, specific conductance, and turbidity. The blue shelter (right) is the housing for the electrical components for the gaging station. The refrigerated automatic sampler and controller are inside the shelter (by Jonathan Evans, USGS).

Background, banks and channel of Crooked Creek near Norcross, Georgia (background and sign photographs by Kerry Caslow, USGS). 


\section{Watershed Characteristics and Water-Quality Trends and Loads in 12 Watersheds in Gwinnett County, Georgia}

By John K. Joiner, Brent T. Aulenbach, and Mark N. Landers

Prepared in cooperation with Gwinnett County Department of Water Resources

Scientific Investigations Report 2014-5141 


\title{
U.S. Department of the Interior SALLY JEWELL, Secretary
}

\section{U.S. Geological Survey \\ Suzette M. Kimball, Acting Director}

\author{
U.S. Geological Survey, Reston, Virginia: 2014
}

For more information on the USGS - the Federal source for science about the Earth, its natural and living resources, natural hazards, and the environment-visit http://www.usgs.gov or call 1-888-ASK-USGS.

For an overview of USGS information products, including maps, imagery, and publications, visit http://WwW.usgs.gov/pubprod

To order this and other USGS information products, visit http://store.usgs.gov

Any use of trade, firm, or product names is for descriptive purposes only and does not imply endorsement by the U.S. Government.

Although this information product, for the most part, is in the public domain, it also may contain copyrighted materials as noted in the text. Permission to reproduce copyrighted items must be secured from the copyright owner.

Suggested citation:

Joiner, J.K., Aulenbach, B.T., and Landers, M.N., 2014, Watershed characteristics and water-quality trends and loads in 12 watersheds in Gwinnett County, Georgia: U.S. Geological Survey Scientific Investigations Report 2014-5141, 79 p., http://dx.doi.org/10.3133/sir20145141.

ISSN 2328-031X (print) ISSN 2328-0328 (online) ISBN 978-1-4113-3815-9 


\section{Contents}

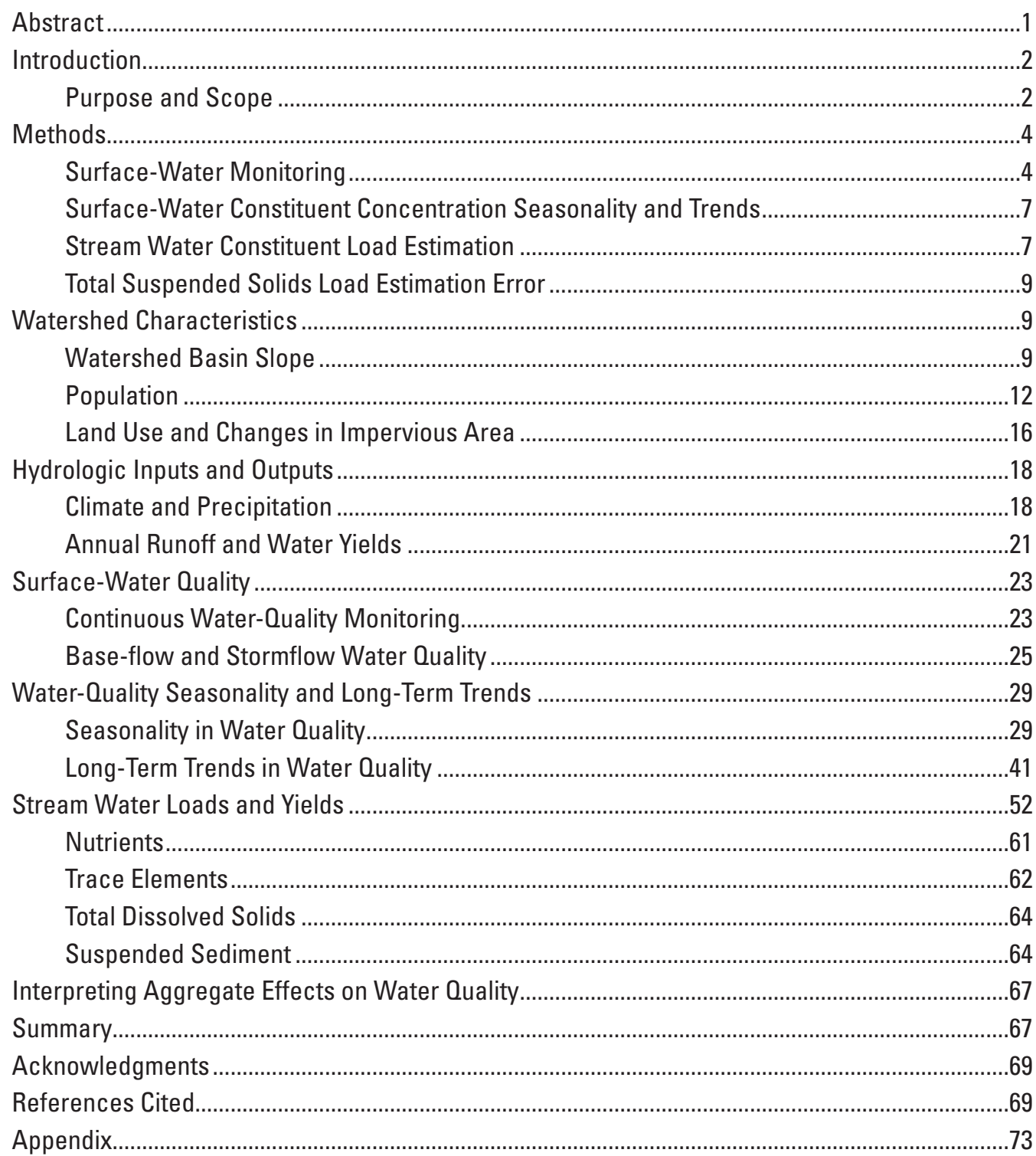

\section{Figures}

1. Map showing location of the study area showing the 12 monitored watersheds and the monitoring stations, Gwinnett County, Georgia....................................................

2. Photographs showing multiparameter monitoring station at North Fork Peachtree Creek at Graves Road, near Doraville, Georgia ................................................................

3. Map showing land-surface altitude for Gwinnett County, Georgia ...............................10

4. Map showing land-surface slope for Gwinnett County, Georgia .....................................11

5. Graph showing average basin slope of the 12 monitored watersheds in Gwinnett

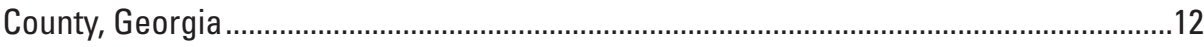

6. Map showing population density for Gwinnett County, Georgia, 2009 ............................13 
7-12. Graphs showing -

7. Population density for the 12 monitored watersheds in Gwinnett County, Georgia, 2009...

8. Total population by year and population growth for Gwinnett County, Georgia, 1996-2013.

9. Percentage of watershed impervious area from transportation and building land cover for 12 monitored watersheds in Gwinnett County, Georgia, 2009.

10. Watershed impervious area as related to high-density land use and population density for 12 monitored watersheds in Gwinnett County, Georgia, 2009.

11. Percentage of impervious area in 12 monitored watersheds in Gwinnett County, Georgia

12. Spatially averaged annual precipitation totals for each of the 12 monitored watersheds in Gwinnett County, Georgia, and the countywide average

13. Contour map showing the average annual precipitation for Gwinnett County,

Georgia, and the 12 monitored watersheds.

14-16. Graphs showing-

14. Annual runoff totals and annual water yields for each of the 12 monitoring stations in Gwinnett County, Georgia

15. Dilution effects of specific conductance and discharge at station 02336030, North Fork Peachtree Creek near Doraville, Georgia, January 5-7, 2009. .23

16. Turbidity in relation to suspended-sediment concentration, total zinc, and total suspended solids at station 02207120 Yellow River near Lithonia, Georgia.

17. Boxplots of concentrations for specific conductance, turbidity, total nitrite plus nitrate, total ammonia plus organic nitrogen, total nitrogen, total phosphorus, dissolved phosphorus, total organic carbon, total lead, total zinc, total dissolved solids, total suspended solids, and, suspended sediment at 12 monitored watersheds in Gwinnett County, Georgia

18-38. Graphs showing-

18. Concentrations of total suspended solids and suspended-sediment concentrations for 380 storm samples collected in watersheds in Gwinnett County, Georgia

19. Seasonal patterns in stormflow total nitrogen flow-adjusted residual concentrations for the 12 monitored watersheds in Gwinnett County, Georgia

20. Seasonal patterns in stormflow total phosphorus flow-adjusted residual concentrations for the 12 monitored watersheds in Gwinnett County, Georgia...

21. Seasonal patterns in stormflow total dissolved solids flow-adjusted residual concentrations for the 12 monitored watersheds in Gwinnett County, Georgia

22. Seasonal patterns in stormflow total suspended solids flow-adjusted residual concentrations for the 12 monitored watersheds in Gwinnett County, Georgia

23. Seasonal patterns in stormflow total zinc flow-adjusted residual concentrations for the 12 monitored watersheds in Gwinnett County, Georgia. 
24. Trends in stormflow total nitrogen flow- and seasonally adjusted residual concentrations for the 12 monitored watersheds in

Gwinnett County, Georgia.

25. Trends in stormflow total phosphorus flow- and seasonally adjusted residual concentrations for the 12 monitored watersheds in

Gwinnett County, Georgia

26. Trends in stormflow total dissolved solids flow- and seasonally adjusted residual concentrations for the 12 monitored watersheds in

Gwinnett County, Georgia

27. Trends in stormflow total suspended solids flow- and seasonally adjusted residual concentrations for the 12 monitored watersheds in

Gwinnett County, Georgia

28. Trends in stormflow total zinc flow- and seasonally adjusted residual concentrations for the 12 monitored watersheds in Gwinnett County, Georgia

29. Total suspended solids in relation to discharge for base-flow and stormflow conditions for samples collected at station 02208150, Alcovy River near Grayson, Georgia, 1997-2009.

30. Average annual yields for total nitrite plus nitrate and total nitrogen, and annual runoff in Gwinnett County, Georgia, water years 2004-09.

31. Average annual total nitrogen and total nitrite plus nitrate yields for 12 monitored watersheds in Gwinnett County, Georgia, water years 2004-09 ........61

32. Average annual total and dissolved phosphorus yields for 12 monitored watersheds in Gwinnett County, Georgia, water years 2004-09.

33. Average annual total organic carbon yields for 12 monitored watersheds in Gwinnett County, Georgia, water years 2004-09.

34. Average annual total lead and zinc yields for 12 monitored watersheds in Gwinnett County, Georgia, water years 2004-09.

35. Average annual total dissolved solids yields for 12 monitored watersheds in Gwinnett County, Georgia, water years 2004-09.

36. Annual total suspended solids yield and runoff at the Alcovy River, Gwinnett County, Georgia, water years 2004-09.

37. Average annual total suspended solids yields for 12 monitored watersheds in Gwinnett County, Georgia, water years 2004-09.

38. Average annual total suspended solids and suspended-sediment concentration yields for 12 monitored watersheds in Gwinnett County, Georgia, water years $2004-09$

\section{Tables}

1. Twelve U.S. Geological Survey water-quantity and water-quality monitoring stations included in the watershed characteristics and water-quality trends study in Gwinnett County, Georgia, including dates established and drainage areas for each station.

2. Water-quality constituents analyzed for samples collected in streams in Gwinnett County, Georgia, units of measures, and detection limit

3. Land use and watershed characteristics for $\mathbf{1 2}$ watersheds in Gwinnett County, Georgia, 2009 
4. Water-quality constituent trends and statistical significance for stormflow samples in 12 monitored watersheds in Gwinnett County, Georgia..

5. Examples of characteristics of regression models used to compute loads of total zinc for the 12 monitored watersheds in Gwinnett County, Georgia.

6. Water year 2004 runoff and constituent yields for each of the 12 monitored watersheds in Gwinnett County, Georgia .55

7. Water year 2005 runoff and constituent yields for each of the 12 monitored watersheds in Gwinnett County, Georgia. 56

8. Water year 2006 runoff and constituent yields for each of the 12 monitored watersheds in Gwinnett County, Georgia. 57

9. Water year 2007 runoff and constituent yields for each of the 12 monitored watersheds in Gwinnett County, Georgia

10. Water year 2008 runoff and constituent yields for each of the 12 monitored watersheds in Gwinnett County, Georgia.

11. Water year 2009 runoff and constituent yields for each of the 12 monitored watersheds in Gwinnett County, Georgia

1-1. Statistical summary for selected constituents, Yellow River at Georgia 124 near Lithonia, Georgia, station number 02207120.

1-2. Statistical summary for selected constituents, No Business Creek at Lee Road, below Snellville, Georgia, station number 02207185

1-3. Statistical summary for selected constituents, Big Haynes Creek at Lenora Road, near Loganville, Georgia, station number 02207385.

1-4. Statistical summary for selected constituents, Brushy Fork Creek at Beaver Road, near Loganville, Georgia, station number 02207400

1-5. Statistical summary for selected constituents, Alcovy River at New Hope Road, near Grayson, Georgia, station number 02208150.

1-6. Statistical summary for selected constituents, Wheeler Creek at Bill Cheek Road, near Auburn, Georgia, station number 02217274

1-7. Statistical summary for selected constituents, Apalachee River at Fence Road, near Dacula, Georgia, station number 02218565

1-8. Statistical summary for selected constituents, Richland Creek at Suwanee Dam Road, near Buford, Georgia, station number 02334480

1-9. Statistical summary for selected constituents, Level Creek at Suwanee Dam Road, near Suwanee, Georgia, station number 02334578.

1-10. Statistical summary for selected constituents, Suwanee Creek at Suwanee, Georgia, station number 02334885

1-11. Statistical summary for selected constituents, Crooked Creek near Norcross, Georgia, station number 02335350 .

1-12. Statistical summary for selected constituents, North Fork Peachtree Creek at Graves Road, near Doraville, Georgia, station number 02336030 


\section{Conversion Factors}

Inch/Pound to SI

\begin{tabular}{|c|c|c|}
\hline Multiply & By & To obtain \\
\hline \multicolumn{3}{|c|}{ Length } \\
\hline inch (in.) & 2.54 & centimeter $(\mathrm{cm})$ \\
\hline inch (in.) & 25.4 & millimeter $(\mathrm{mm})$ \\
\hline foot $(\mathrm{ft})$ & 0.3048 & meter $(\mathrm{m})$ \\
\hline mile (mi) & 1.609 & kilometer $(\mathrm{km})$ \\
\hline \multicolumn{3}{|c|}{ Area } \\
\hline acre & 0.4047 & hectare (ha) \\
\hline acre & 0.004047 & square kilometer $\left(\mathrm{km}^{2}\right)$ \\
\hline square mile $\left(\mathrm{mi}^{2}\right)$ & 259.0 & hectare (ha) \\
\hline square mile $\left(\mathrm{mi}^{2}\right)$ & 2.590 & square kilometer $\left(\mathrm{km}^{2}\right)$ \\
\hline \multicolumn{3}{|c|}{ Flow rate } \\
\hline inch per hour (in/h) & 0.0254 & meter per hour $(\mathrm{m} / \mathrm{h})$ \\
\hline inch per year (in/yr) & 25.4 & millimeter per year $(\mathrm{mm} / \mathrm{yr})$ \\
\hline \multicolumn{3}{|c|}{ Mass } \\
\hline pound, avoirdupois (lb) & 0.4536 & kilogram $(\mathrm{kg})$ \\
\hline
\end{tabular}

Temperature in degrees Celsius $\left({ }^{\circ} \mathrm{C}\right)$ may be converted to degrees Fahrenheit $\left({ }^{\circ} \mathrm{F}\right)$ as follows:

$$
{ }^{\circ} \mathrm{F}=\left(1.8 \times{ }^{\circ} \mathrm{C}\right)+32
$$

Temperature in degrees Fahrenheit $\left({ }^{\circ} \mathrm{F}\right)$ may be converted to degrees Celsius $\left({ }^{\circ} \mathrm{C}\right)$ as follows:

$$
{ }^{\circ} \mathrm{C}=\left({ }^{\circ} \mathrm{F}-32\right) / 1.8
$$

Vertical coordinate information is referenced to the North American Vertical Datum of 1988 (NAVD 88).

Altitude, as used in this report, refers to distance above the vertical datum.

Specific conductance is given in microsiemens per centimeter at 25 degrees Celsius $(\mu \mathrm{S} / \mathrm{cm}$ at $\left.25^{\circ} \mathrm{C}\right)$.

Concentrations of chemical constituents in water are given either in milligrams per liter ( $\mathrm{mg} / \mathrm{L}$ ) or micrograms per liter $(\mu \mathrm{g} / \mathrm{L})$. 


\section{Abbreviations}

$\begin{array}{ll}\text { AMLE } & \text { adjusted maximum likelihood estimates } \\ \text { BMP } & \text { best management practices } \\ \text { C } & \text { carbon } \\ \text { DP } & \text { dissolved phosphorus } \\ \text { EWI } & \text { equal-width increment } \\ \text { TKN } & \text { total Kjeldahl nitrogen } \\ \text { TP } & \text { total phosphorus } \\ \text { LOWESS } & \text { locally weighted regression and smoothing scatterplots } \\ \text { LTTM } & \text { Long-Term Trend Monitoring } \\ \text { MNGWPD } & \text { Metropolitan North Georgia Water Planning District } \\ \text { N } & \text { nitrogen } \\ \text { NO }{ }_{2}+\text { NO }_{3} & \text { nitrite plus nitrate } \\ \text { NPDES } & \text { National Pollutant Discharge Elimination System } \\ \text { P } & \text { phosphorus } \\ \text { Pb } & \text { total lead } \\ \text { SC } & \text { specific conductance } \\ \text { SE } & \text { standard error } \\ \text { SEP } & \text { standard error of the prediction } \\ \text { SSC } & \text { suspended-sediment concentration } \\ \text { TDS } & \text { total dissolved solids } \\ \text { TMDL } & \text { total maximum daily load } \\ \text { TN } & \text { total nitrogen } \\ \text { TOC } & \text { total organic carbon } \\ \text { TSS } & \text { total suspended solids } \\ \text { USGS } & \text { U.S. Geological Survey } \\ \text { WY } & \text { water year } \\ \text { Zn } & \\ & \text { total zinc } \\ & \end{array}$




\title{
Watershed Characteristics and Water-Quality Trends and Loads in 12 Watersheds in Gwinnett County, Georgia
}

\author{
By John K. Joiner, Brent T. Aulenbach, and Mark N. Landers
}

\section{Abstract}

The U.S. Geological Survey, in cooperation with Gwinnett County Department of Water Resources, established a Long-Term Trend Monitoring (LTTM) program in 1996. The LTTM program is a comprehensive, long-term, water-quantity and water-quality monitoring program designed to document and analyze the hydrologic and water-quality conditions of selected watersheds of Gwinnett County, Georgia. Waterquality monitoring initially began in six watersheds and was expanded to another six watersheds in 2001.

As part of the LTTM program, streamflow, precipitation, water temperature, specific conductance, and turbidity were measured continuously at the 12 watershed monitoring stations for water years ${ }^{1}$ 2004-09. In addition, discrete waterquality samples were collected seasonally from May through October (summer) and November through April (winter), including one base-flow and three stormflow event composite samples, during the study period. Samples were analyzed for nutrients (nitrogen and phosphorus), total organic carbon, trace elements (total lead and total zinc), total dissolved solids, and total suspended sediment (total suspended solids and suspended-sediment concentrations). The sampling scheme was designed to identify variations in water quality both hydrologically and seasonally.

The 12 watersheds were characterized for basin slope, population density, land use for 2009 , and the percentage of impervious area from 2000 to 2009. Precipitation in water years 2004-09 was about 18 percent below average, and the county experienced exceptional drought conditions and below average runoff in water years 2007 and 2008. Watershed water yields, the percentage of precipitation that results in runoff, typically are lower in low precipitation years and are higher for watersheds with the highest percentages of impervious areas.

A comparison of base-flow and stormflow water-quality samples indicates that turbidity and concentrations of total ammonia plus organic nitrogen, total nitrogen, total phosphorus, total organic carbon, total lead, total zinc, total suspended

\footnotetext{
${ }^{1}$ A water year is the period from October 1 to September 30 and is designated by the year in which the period ends.
}

solids, and suspended-sediment concentrations increased with increasing discharge at all watersheds. Specific conductance, however, decreased during stormflow at all watersheds, and total dissolved solids concentrations decreased during stormflow at a few of the watersheds. Total suspended solids and suspended-sediment concentrations typically were two orders of magnitude higher in stormflow samples, turbidities were about 1.5 orders of magnitude higher, total phosphorus and total zinc were about one order of magnitude higher, and total ammonia plus organic nitrogen, total nitrogen, total organic carbon, and total lead were about twofold higher than in base-flow samples.

Seasonal patterns and long-term trends in flow-adjusted water-quality concentrations were identified for five representative constituents - total nitrogen, total phosphorus, total zinc, total dissolved solids, and total suspended solids. Seasonal patterns for all five constituents were fairly similar, with higher concentrations in the summer and lower concentrations in the winter. Significant linear long-term trends in stormflow composite concentrations were identified for 36 of the 60 constituent-watershed combinations ( 5 constituents multiplied by 12 watersheds) for the period of record through water year 2011. Significant trends typically were decreasing for total nitrogen, total phosphorus, total suspended solids, and total zinc and increasing for total dissolved solids. Total dissolved solids and total suspended solids trends had the largest magnitude changes per year.

Stream water loads were estimated for 10 water-quality constituents. These estimates represent the cumulative effects of watershed characteristics, hydrologic processes, biogeochemical processes, climatic variability, and human influences on watershed water quality. Yields, in load per unit area, were used to compare loads from watersheds with different sizes. A load estimation approach developed for the Gwinnett County LTTM program that incorporates storm-event composited samples was used with some minor modifications. This approach employs the commonly used regression-model method. Concentrations were modeled as a function of discharge, time, season, and turbidity to improve model predictions and reduce errors in load estimates. Total suspended solids annual loads have been identified in Gwinnett County's Watershed Protection Plan for target performance criterion. 
The amount of annual runoff is the primary factor in determining the amount of annual constituent loads. Below average runoff during water years 2004-09, especially during water years $2006-08$, resulted in corresponding below average loads. Variations in constituent yields between watersheds appeared to be related to various watershed characteristics. Suspended sediment (total suspended solids and suspendedsediment concentrations) along with constituents transported predominately in solid phase (total phosphorus, total organic carbon, total lead, and total zinc) and total dissolved solids typically had higher yields from watersheds that had high percentages of impervious areas or high basin slope. High total nitrogen yields were also associated with watersheds with high percentages of impervious areas. Low total nitrogen, total suspended solids, total lead, and total zinc yields appear to be associated with watersheds that have a low percentage of high-density development. Total suspended solids yields were lower in drought years, water years $2007-08$, from the combined effects of less runoff and the result of fewer, lower magnitude storms, which likely resulted in less surface erosion and lower stream sediment transport.

\section{Introduction}

Watershed surface-water quantity and water quality reflect and integrate the effects of watershed characteristics, inputs (for example, precipitation and dry deposition), hydrologic and biogeochemical processes, climatic variability (such as droughts and floods), and human influences. Changes in land use alter complex interactions that affect many processes within a watershed (MacDonald, 2000). Urbanization, with its associated increases in impervious area, can have a great effect on stream hydrology by (1) decreasing rainfall infiltration and groundwater recharge rates, resulting in lower stream base flow, and (2) increasing storm runoff, peak discharges, and flood flows (Leopold, 1968). Urbanization and the resulting hydrologic response can affect surface-water quality by increasing surface erosion, sediment transport, and pollutant loadings and by altering stream-channel stability. Best management practices (BMPs; for example, stormwater detention ponds, diversion structures, and stream buffers) and other erosion controls frequently are implemented to mitigate the effects of urbanization on stream hydrology and minimize sediment transport in urbanized areas. Monitoring specific water-quality constituents allows for the identification of trends and the computation of loads and yields to help attribute changes in water quality to natural variations as opposed to those related to changes in land use and watershed management strategies.

The U.S. Geological Survey (USGS), in cooperation with Gwinnett County Department of Water Resources, established a comprehensive Long-Term Trend Monitoring (LTTM) program in 1996 to monitor, analyze, and quantify the magnitudes of pollutants and the effects of urbanization on six watersheds. In 2001, six additional watersheds were added to the LTTM program (fig. 1). These 12 watersheds were continuously monitored during water years (WYs)
2004-09 for water level (stage), discharge, precipitation, and water-quality properties (water temperature, specific conductance [SC], and turbidity). Three stormflow-composited samples and one base-flow sample were collected in both summer (May-October) and winter (November-April) of each year; samples were analyzed for nutrients, trace metals, total dissolved solids, and total suspended sediment (total suspended solids and suspended-sediment concentration). The sampling scheme was designed to identify variations in water quality both hydrologically and seasonally.

The primary purpose of the monitoring program is to collect and interpret consistent, high-quality water-quantity and water-quality data. Watershed managers can use these data to make informed management decisions in order to maintain the designated uses of streams, protect aquatic habitats, and optimize the effectiveness of water-management practices (BMPs). Intensive, long-term monitoring of watershed characteristics, streamflow, and stream quality are essential to quantifying the impacts of specific land uses, point-source and nonpoint-source discharges, and management processes on surface water (water quantity, flow characteristics, and water quality). The LTTM program also fulfills requirements outlined in the Gwinnett County Watershed Protection Plan as well as requirements for the National Pollutant Discharge Elimination System (NPDES) permit and the Metropolitan North Georgia Water Planning District (MNGWPD).

\section{Purpose and Scope}

The purpose of this report is to summarize and analyze the hydrologic, water-quality, and land-use data collected as part of Gwinnett County's LTTM program for 12 watersheds for the 6-year period WYs 2004-09. This report is an update to, and continuation of, the report by Landers and others (2007) that presented and analyzed data for the original six watersheds for WYs 1996-2003. The specific goals of this report are to:

- Expand the watershed characterization reported in Landers and others (2007) to include the additional six watersheds added to the LTTM program;

- Discuss changes and trends in population, land use, and impervious area;

- Report annual hydrologic inputs and outputs (precipitation and runoff);

- Summarize water-quality data through WY 2009;

- Determine trends for five representative water-quality constituents (total nitrogen, total phosphorus, total dissolved solids, total suspended solids, and total zinc) for the period of record through WY 2011, and;

- Provide annual load and yield estimates for 10 constituents (total nitrite plus nitrate, total nitrogen, total phosphorus, dissolved phosphorus, total organic carbon, total lead, total zinc, total dissolved solids, total suspended solids, and suspended sediment) for WYs 2004-09. 

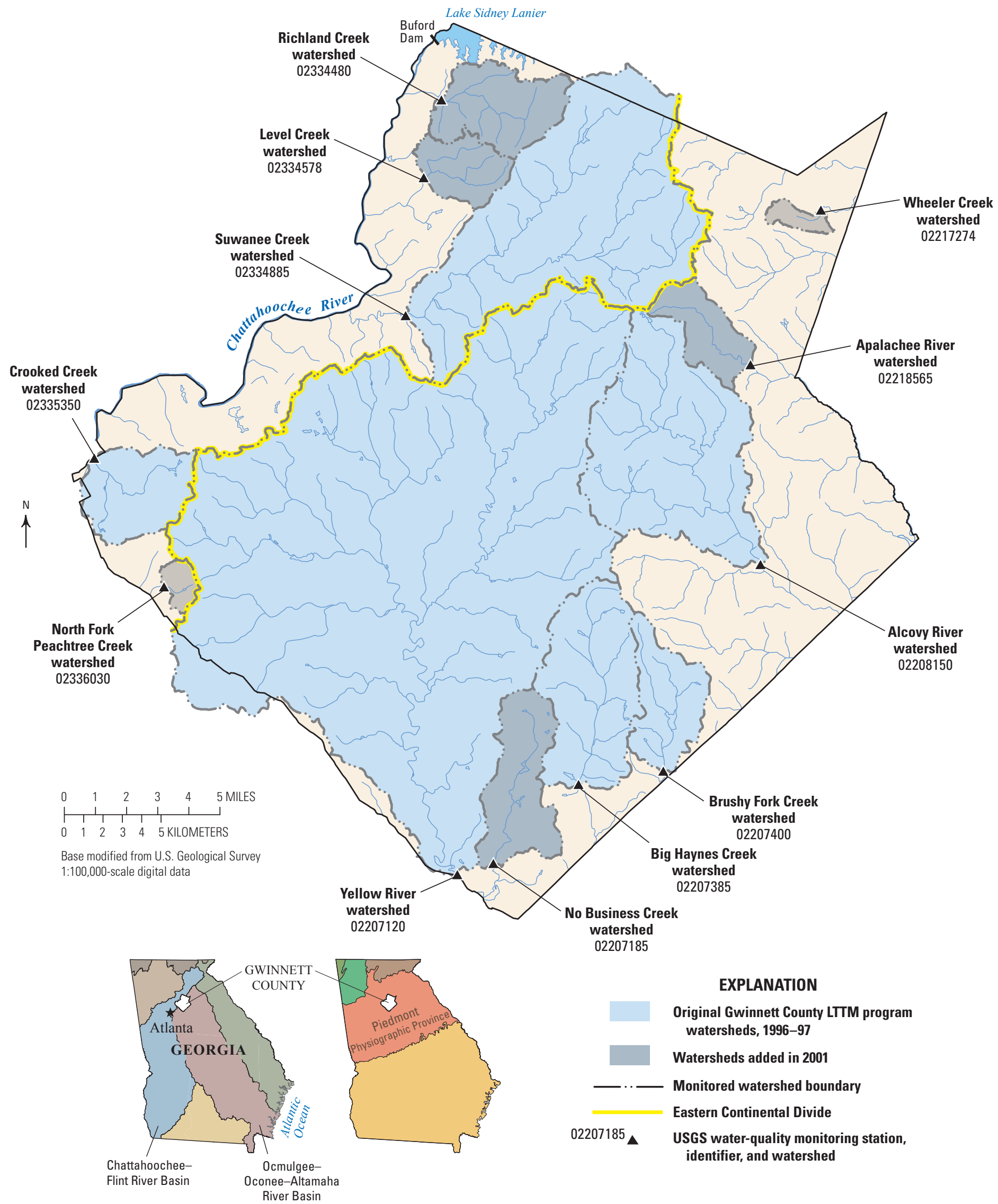

\section{EXPLANATION}

Original Gwinnett County LTTM program watersheds, 1996-97

Watersheds added in 2001

Monitored watershed boundary

Eastern Continental Divide

USGS water-quality monitoring station, identifier, and watershed

Figure 1. Location of the study area showing the 12 monitored watersheds and the monitoring stations, Gwinnett County, Georgia. 


\section{Methods}

Twelve watersheds in Gwinnett County, Georgia, were monitored for stage, discharge, precipitation, and continuous water-quality properties as part of the LTTM program. Samples were collected during base-flow and stormflow events and were analyzed for 12 water-quality constituents. Seasonal patterns and long-term trends were identified in a representative subset of water-quality constituents in both base-flow and stormflow samples. Stream water loads were estimated for 10 water-quality constituents.

\section{Surface-Water Monitoring}

The Gwinnett County LTTM program consists of 12 watersheds monitored at their outlets for stage (water level), discharge, precipitation, and continuous water-quality constituents. Surface water-quality samples were collected seasonally during base-flow conditions and stormflow events at each watershed gaging station. The samples were analyzed for 12 selected constituents, including field properties, nutrients, trace metals, suspended sediment, and total dissolved solids. Initially, six watersheds were monitored when the LTTM program started in 1996: (1) Brushy Fork Creek, (2) Alcovy River, (3) Big Haynes Creek, (4) Suwanee Creek, (5) Yellow River, and (6) Crooked Creek Basins. In 2001, six additional watersheds were added to the LTTM program: (7) No Business Creek, (8) Wheeler Creek, (9) Apalachee River, (10) Richland Creek, (11) Level Creek, and (12) North Fork Peachtree Creek Basins (table 1). Program watersheds were selected to ensure diverse basin characteristics and land use for evaluating streamflow quantity and quality characteristics, while ensuring an appropriate spatial coverage of the county. The selected watersheds have variable water-quality attainment status (whether or not water-quality standards are met) and contain a diverse amount of point-source discharges. The specific monitoring station locations were determined on the basis of the suitability for hydrologic instrumentation and personnel safety.

The LTTM program follows standard USGS protocols for measuring stage, making streamflow measurements, and computing discharge (Rantz and others, 1982a, 1982b). Stage is recorded every 15 -minutes to the nearest 0.01 foot and is routinely verified to an outside reference gage. This reference gage is periodically checked with surveying levels and other established reference marks to verify the gage datum. Discharge measurements are made over a wide range of hydrologic conditions to develop a stage-discharge relation at each monitoring station used to compute discharge from the stage measurements. Discharge measurements were regularly made in order to continually refine the stage-discharge relation and to account for any temporal changes in the relation due to changes in the shape of the streambed. Discharge for periods of missing or unreliable stage data were estimated from relations in hydrograph data between the station with the missing data and from nearby basins having similar characteristics (Rantz, 1982b).

Precipitation was measured at each station and was recorded at 15-minute intervals, using self-calibrating tipping bucket rain gages that measure precipitation in 0.01 -inch increments. The rain gages were routinely cleaned and calibrated as outlined in the Surface-Water Quality-Assurance Plan for the USGS Georgia Water Science Center (Gotvald, 2010).

Table 1. Twelve U.S. Geological Survey (USGS) water-quantity and water-quality monitoring stations included in the watershed characteristics and water-quality trends study in Gwinnett County, Georgia, including dates established and drainage areas for each station.

\begin{tabular}{cllc}
\hline $\begin{array}{c}\text { USGS station } \\
\text { number }\end{array}$ & \multicolumn{1}{c}{ Station name } & Date established & $\begin{array}{c}\text { Drainage area } \\
\text { (square miles) }\end{array}$ \\
\hline 02207120 & Yellow River at GA Hwy 124 near Lithonia, GA & April 1996 & 162 \\
02207185 & No Business Creek at Lee Road, below Snellville, GA & March 2001 & 10.1 \\
\hline 02207385 & Big Haynes Creek at Lenora Road, near Snellville, GA & June 1996 & 17.3 \\
\hline 02207400 & Brushy Fork Creek at Beaver Road near Loganville, GA & June 1996 & 8.15 \\
\hline 02208150 & Alcovy River at New Hope Road, near Grayson, GA & June 1997 & 30.8 \\
\hline 02217274 & Wheeler Creek at Bill Cheek Road, near Auburn, GA & June 2001 & 1.31 \\
\hline 02218565 & Apalachee River at Fence Road, near Dacula, GA & July 2001 & 5.68 \\
\hline 02334480 & Richland Creek at Suwanee Dam Road, near Buford, GA & May 2001 & 9.34 \\
\hline 02334578 & Level Creek at Suwanee Dam Road, near Suwanee, GA & May 2001 & 5.04 \\
\hline 02334885 & Suwanee Creek at Suwanee, GA & September 1996 & 47 \\
\hline 02335350 & Crooked Creek near Norcross, GA & March 1996 & 8.89 \\
02336030 & North Fork Peachtree Creek at Graves Road, near Doraville, GA & June 2001 & 1.42 \\
\hline
\end{tabular}


Continuous water-quality monitors were deployed at each monitoring station to measure water temperature, SC, and turbidity at 15 -minute intervals. These water-quality monitors typically are cleaned and their calibration checked every 2 weeks and more frequently following hydrologic events or after observing abnormal readings, which could be associated with point sources or nonpoint sources of pollution. These water-quality monitors are maintained, and their corresponding sensor records are checked using the quality-assurance and quality-control procedures outlined in Wagner and others (2006).

All continuously monitored data (stage, precipitation, and water quality) are transmitted hourly by way of satellite communication and are made available to the public at the USGS Web site as values and time-series plots, which can be accessed at http://waterdata.usgs.gov/ga/nwis/ current/?type $=$ flow\&group_key=basin_cd. Due to public interest in receiving the data in near real-time during periods of extreme runoff, each station is designed to send emergency transmissions every 15 minutes during these periods. These transmissions occur when rainfall intensities exceed 2 inches per hour or when there are large rates of change in stage, as determined from thresholds defined for each station. The real-time data combined with the USGS WaterAlert tool (http://maps.waterdata.usgs.gov/mapper/wateralert/) can be used as a flood warning system for emergency managers and the public. A typical multiparameter stream monitoring station is shown in figure 2 .

Two discrete base-flow samples and six stormflow samples were collected each year at each of the 12 stations for water-quality analyses. The year is divided into two seasons, summer (May through October) and winter (November through April), with one base-flow sample and three stormflow samples collected during each season. Base-flow samples were collected using a USGS DH-81 manual sampler, using depth integrated, equal-width-increment (EWI) integrating techniques to ensure a representative sample as outlined in the National Field Manual for the Collection of Water-Quality Data (U.S. Geological Survey, variously dated). Base-flow samples were collected after no more than 0.1 inch of precipitation had fallen during the previous 72 hours. During base-flow sampling, a water-quality "sonde" was used to concurrently measure the field properties of $\mathrm{pH}$, turbidity, $\mathrm{SC}$, water temperature, and dissolved oxygen in accordance with the Watershed Protection Plan for Gwinnett County (Gwinnett County Department of Public Utilities, 2000).

Stormflow samples were collected using automatic samplers that pump water from a designated point in the stream. The sampler is programmed to begin sampling when precipitation and (or) stage thresholds are reached, and a sample is collected each time a specified volume of water flows by the station. These samples are composited into a

Figure 2. Multiparameter monitoring station at North Fork Peachtree Creek at Graves Road, near Doraville, Georgia. (USGS station number 02336030; photographs by Jonathan Evans, USGS)
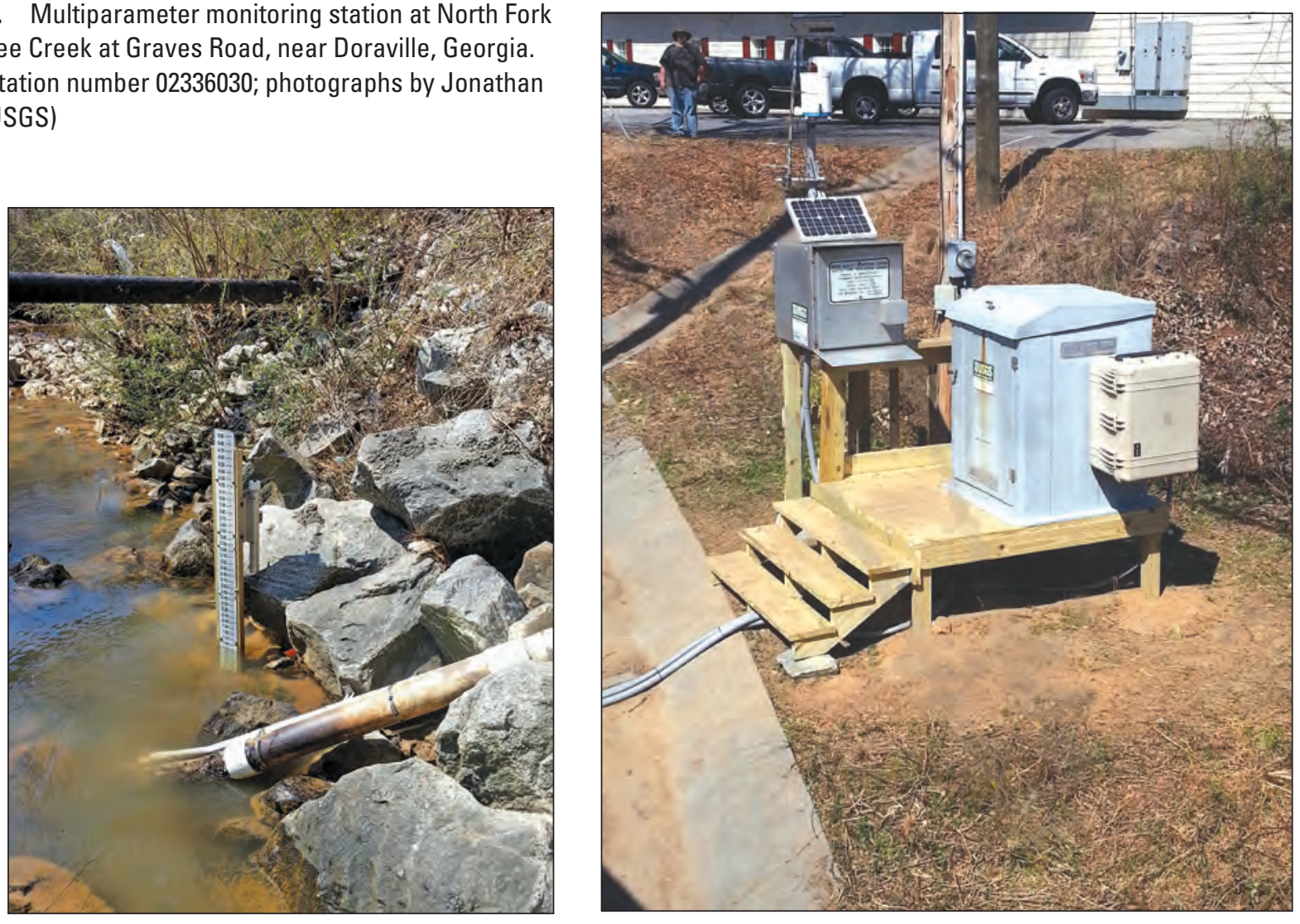
single discharge-weighted event sample for water-quality analysis, which is assumed to be representative of the constituent concentration variations that occur during an event. All stormflow samples are collected in accordance with the applicable wastewater permits and Watershed Protection Plan for Gwinnett County (Gwinnett County Department of Public Utilities, 2000). Stormflow samples are required to be collected during an event in which a minimum of 0.3 inch of precipitation occurs. Additionally, a minimum of 72 hours is required between each event to ensure that the events are discrete and that the measured water-quality properties are associated with the sampled event.

The automatic sampler tubing and intake are cleaned and prepared prior to each sampling event. The programmed volume at which each sample is collected is set in accordance with the anticipated magnitude of the approaching storm. The samples are refrigerated in the automatic sampler at about 4 degrees Celsius and are retrieved from the sampler within 24 hours of the end of an event. Sampler cleaning and maintenance procedures are further documented in the USGS Georgia Water Science Center quality-assurance plan (S.J. Lawrence, U.S. Geological Survey, written commun., April 6, 2010). Because automatic samplers collect samples from a single point in the stream cross section, periodic concurrent EWI and automatic samples are collected. These samples are independently analyzed and compared to ensure that the automatic point sample is representative of the entire stream cross section.
Base-flow and stormflow samples were processed and preserved following USGS field methods (U.S. Geological Survey, variously dated) and were analyzed for 10 constituents: nutrients (total nitrite plus nitrate $\left[\mathrm{NO}_{2}+\mathrm{NO}_{3}\right]$, total ammonia plus organic nitrogen [total Kjeldahl nitrogen, TKN], total phosphorus [TP], dissolved phosphorus [DP], and total organic carbon $[\mathrm{TOC}]$ ); trace metals (total lead $[\mathrm{Pb}]$ and total zinc $[\mathrm{Zn}])$; total dissolved solids (TDS); and sediment concentrations (total suspended solids [TSS] and suspended sediment [SSC]) in USGS laboratories in Lakewood, Colorado; Atlanta, Georgia; and other USGS-approved laboratories. Total nitrogen (TN) was calculated as the sum of $\mathrm{NO}_{2}+\mathrm{NO}_{3}$ and TKN. Units of measurement and laboratory detection limits for each constituent are listed in table 2. The detection limits for some constituents have changed over time due to changes in approved laboratory methods. The detection limits listed in table 2 reflect the analytical methods used during the 2004-09 water years discussed in this report. Several constituents that were included in the 1996-2003 period of this study have been discontinued as of 2004: total cadmium, total chromium, total copper, biological oxygen demand, and chemical oxygen demand. Field water-quality blank and replicate samples were collected in compliance with USGS protocols (U.S. Geological Survey, 2006); laboratory analyses include an extensive quality-control and quality-assurance program.

The amount of suspended sediment in water was determined in this study using two different laboratory analytical methods - SSC and TSS. The SSC analytical method

Table 2. Water-quality constituents analyzed for samples collected in streams in Gwinnett County, Georgia, units of measures, and detection limit.

$\left[\mu \mathrm{S} / \mathrm{cm}\right.$, microsiemens per centimeter; ${ }^{\circ} \mathrm{C}$, degrees Celsius; FNU, formazin nephelometric units; $\mathrm{mg} / \mathrm{L}$, milligrams per liter; N, nitrogen; P, phosphorus; C, carbon; $\mu \mathrm{g} / \mathrm{L}$, micrograms per liter; na, not applicable]

\begin{tabular}{lclc}
\hline \multicolumn{1}{c}{ Constituent } & $\begin{array}{c}\text { Constituent } \\
\text { abbreviation }\end{array}$ & Units & $\begin{array}{c}\text { Laboratory } \\
\text { detection } \\
\text { limit }\end{array}$ \\
\hline Specific conductance & $\mathrm{SC}$ & $\mu \mathrm{S} / \mathrm{cm}$ at $25^{\circ} \mathrm{C}$ & na \\
\hline Turbidity ${ }^{1}$ & $\mathrm{na}$ & $\mathrm{FNU}$ & na \\
\hline Total nitrite plus nitrate & $\mathrm{NO}_{2}+\mathrm{NO}_{3}$ & $\mathrm{mg} / \mathrm{L}$ as N & 0.019 \\
\hline Total ammonia plus organic nitrogen & $\mathrm{TKN}$ & $\mathrm{mg} / \mathrm{L}$ as N & 0.25 \\
\hline Total nitrogen & $\mathrm{TN}$ & $\mathrm{mg} / \mathrm{L}$ as N & Calculated \\
\hline Total phosphorus & $\mathrm{TP}$ & $\mathrm{mg} / \mathrm{L}$ as $\mathrm{P}$ & 0.02 \\
\hline Dissolved phosphorus & $\mathrm{DP}$ & $\mathrm{mg} / \mathrm{L}$ as $\mathrm{P}$ & 0.02 \\
\hline Total organic carbon & $\mathrm{TOC}$ & $\mathrm{mg} / \mathrm{L}$ as C & 1.0 \\
\hline Total lead & $\mathrm{Pb}$ & $\mu \mathrm{g} / \mathrm{L}$ & 1.0 \\
\hline Total zinc & $\mathrm{Zn}$ & $\mu \mathrm{g} / \mathrm{L}$ & 2.0 \\
\hline Total dissolved solids & $\mathrm{TDS}$ & $\mathrm{mg} / \mathrm{L}$ & 1.0 \\
\hline Total suspended solids & $\mathrm{TSS}$ & $\mathrm{mg} / \mathrm{L}$ & 1.0 \\
\hline Suspended sediment & $\mathrm{SSC}$ & $\mathrm{mg} / \mathrm{L}$ & 1.0 \\
\hline
\end{tabular}

${ }^{1}$ Turbidity measured by monochrome near infrared light emitting diode (LED), 780-900 nanometers, detection angle $90 \pm 2.5$ degrees, in formazin nephelometric units (FNU). 
measures the dry weight of the sediment in an entire sample of a known volume, and the TSS method involves measuring the dry weight of sediment in a subsample of the available sample volume, rather than the entire sample (Landers, 2013). Annual yield of TSS is the primary performance criterion for suspended sediment in Gwinnett County's Watershed Protection Plan (Gwinnett County Department of Public Utilities, 2000).

\section{Surface-Water Constituent Concentration Seasonality and Trends}

Analysis of long-term trends often requires a decade or more of monitoring because natural variability can obscure trends, there can be a lag time between watershed changes and water-quality effects, and effects from multiple activities within a watershed can offset each other (Landers and others, 2007). Water quality varies in response to many natural processes, such as changes in discharge, seasonal biogeochemical processes, and climatic variations, which makes it difficult to attribute cause to changes in water quality. It is therefore imperative to remove the effects of natural variation from water- quality data in order to determine trends that may be the result of human influences; for example, many water-quality constituents vary strongly with discharge, which can easily obscure smaller, underlying variations, making it important to remove the effects of discharge on water quality. For long-term trends, the effects of seasonal variability on water quality are less of an issue because of the relatively short-term, recurring nature.

Trend analysis is performed on water-quality concentrations rather than load estimates because it is easier to remove the effects of climatic variability on concentrations and because predefined formulations for seasonality and long-term trend terms in the load estimates may alter the conceptualization of any patterns and trends. To remove the effects of discharge on water-quality concentrations, the evaluations of trend and seasonality are performed on the residual concentrations to a linear regression of log-transformed concentration as a function of log-transformed discharge (Hirsch and others, 1991) for each constituent/station combination. Residuals are defined as the observed concentration minus the predicted concentration. For the long-term trend analysis, concentrations are also seasonally adjusted. Although the effects of discharge are removed, climatic effects may not necessarily be fully accounted. For example, in a drought, the flow-adjusted residual concentrations would compensate for the systematically lower discharges, but the concentration-discharge relation may also be altered by drought conditions, resulting in additional unexplained variance in water quality. It can also be difficult to parse out whether a change in the concentrationdischarge relation over time is the result of climatic variability or human influences.

Seasonal patterns and long-term trends in water quality were analyzed for five representative constituents - TN and TP (representing nitrogen and phosphorus nutrients), TDS (representing dissolved constituents), TSS (representing suspended sediment), and $\mathrm{Zn}$ (representing trace elements). Although most results presented in this report are for the period of record through WY 2009, the seasonal pattern and long-term trend analysis was for the period of record through WY 2011. Extending this analysis minimizes the effects of an unusual year on seasonality and improves the chances of detecting long-term trends.

Seasonal variations in water-quality concentrations can be the result of both natural variations - such as seasonal variability in base flow, the types of weather systems (storms), and biogeochemical processes - and human influences attributed to seasonal practices, such as construction, agriculture, and fertilizer application. To examine seasonal variability, flow-adjusted residual concentrations were plotted in logarithmic space in relation to month and then a smoothed line known as locally weighted regression and smoothing scatterplots (LOWESS; Cleveland, 1979) was fitted to the residual concentrations so that the seasonal pattern could easily be discerned.

Long-term trends were determined separately for base-flow and stormflow samples. The significance of a linear fit of the flow-adjusted and seasonally adjusted residual concentrations with time is used to determine the presence of a trend ( $p$-value less than or equal to 0.10$)$. If a significant trend is determined, a linear trend line was fitted to the residual concentrations in logarithmic space to better illustrate the trend in water quality. Logarithmic space was used because the regression model was based on log-transformed concentration and using logarithmic space made it easier to compare the slope of the trend of different water-quality constituents.

\section{Stream Water Constituent Load Estimation}

Stream water constituent load, often referred to as mass flux, is the mass of chemical solutes or sediment transported at a point in a stream during a specific period. Load serves as an integrated measure of all processes within the watershed that affect water quality (for example, Semkin and others, 1994). With increased emphasis on watershed-based strategies for the control of nonpoint-source pollutants, reliable, temporal measures of loads are needed to address whether water quality is improving or degrading within a reasonably short period of time. In the United States, stream reaches that do not meet U.S. Environmental Protection Agency water-quality standards (U.S. Environmental Protection Agency, 2000a) are subject to waste-load allocation schemes that are based on the total maximum daily load (TMDL). A TMDL is defined as the maximum amount of a pollutant that a water body can receive and still meet water-quality standards (U.S. Environmental Protection Agency, 2000b). Load is highly dependent on the amount of runoff; hence, large watersheds typically will transport high loads. To better compare load from different sized watersheds, load is divided by the watershed area to determine yield, which is the load per unit area. 
Stream water constituent load $(L)$ is the product of constituent concentration $(C)$ and discharge $(Q)$ integrated over time $(t)$ :

$$
L=\int C(t) Q(t) d t
$$

Load estimation using the integral in equation 1 requires a continuous record of both concentration and discharge. Although discharge can readily be measured in a nearly continuous manner, constituent concentration typically is measured less frequently because of the effort and expense of collecting and analyzing samples for water quality. Therefore, various techniques have been developed to estimate loads using discrete concentration observations. These methods can be categorized into four classes: (1) averaging methods, (2) period-weighted approaches (for example, Likens and others, 1977; Larson and others, 1995), (3) regression-model methods, and (4) ratio estimators (for example, Dann and others, 1986; Preston and others, 1989). In the current study, a regression-model (or rating-curve) method is used to estimate loads. In this approach, $C(t)$ is estimated continuously using a regression model that relates concentration to a continuously measured variable, such as discharge and day of year (Johnson, 1979; Crawford, 1991; Cohn and others, 1992), thus enabling a direct calculation of equation 1. The concentration model predicts the average concentration response for the set conditions, such as discharge and season.

Regression-models and load estimates were developed and estimated using the USGS LOAD ESTimator software (LOADEST; Runkel and others, 2004), using the adjusted maximum likelihood estimates (AMLE) algorithm (Cohn and others, 1989, 1992). This algorithm applies a correction factor to account for retransformation bias of a logarithmic model transformed back to linear space (Ferguson, 1986) and can appropriately handle censored water-quality data - concentrations that are below the analytical detection limit. The TIBCO Spotfire S+ statistical software version of LOADEST software was used in this analysis.

Stormflow samples for the Gwinnett LTTM program generally are collected as storm composites. Composite samples are hydrodynamically different than discrete samples; hence, Landers and others (2007) developed an alternative regression method that can be used to estimate loads separately for base-flow and stormflow conditions in order to apply the different modeled concentration discharge relations to the appropriate flow regime. In this method, separate concentration models are fit between concentration and instantaneous discharge for base-flow samples and between average event concentration and average event discharge for the stormflow samples. An analysis was done for each watershed to determine the optimal time-step to use for stormflow load estimation. LOADEST can estimate loads at time intervals as short as 1 hour. The fitted time-step is related to the average duration of storms sampled for each watershed. The time-step is longer for larger watersheds because of the integration of runoff over a larger area with varied and longer travel times to the watershed outlet as well as the attenuation of the storm hydrograph as the runoff travels downstream, which reduces peak flows and spreads out the hydrograph over time. A graphical hydrograph separation was then performed using the HYdrograph SEParation (HYSEP) software developed by the USGS (Sloto and Crouse, 1996) to determine whether each time interval represented base-flow or stormflow conditions. The loads were then estimated using both the base-flow and stormflow concentration models, and the loads were compiled for each time interval, depending on the hydrograph separation.

For this update of the Gwinnett County LTTM program watershed loads for WYs 2004-09, two changes in approach have been made to the Landers and others (2007) method. First, instead of building two separate base-flow and stormflow concentration models, a single model was fit with a base-flow/ stormflow variable to indicate whether sampling conditions were base flow $(=0)$ or stormflow $(=1)$. This approach forced the model parameters to be the same for both flow regimes (for example, same concentration-discharge slope, same seasonality variations) with the exception of an offset as determined by the multiplier of the base-flow/stormflow parameter. This combining of models expedited the model-building step while still fitting the base-flow and stormflow samples. Second, the hydrograph separation was based on levels of turbidity or discharge instead of the dynamics of the hydrograph, which requires a hydrograph separation. For the streams in this study, turbidities greater than 20 formazin nephelometric units (FNU) were determined to be indicative of stormflow; therefore, conditions were determined as stormflow when turbidity from the continuous water-quality sensor was greater than or equal to this $20 \mathrm{FNU}$ threshold. If turbidity data were missing, then discharge was used to determine stormflow conditions - stormflow occurred when discharge was greater than the average of the 50th and the 75th percentiles of discharge for that watershed. Both of these changes appear to have little effect on the estimated loads, because a comparison of loads made using both approaches for WY 2003 indicated that the values were similar.

The regression models used for load estimation had the form of logarithm of concentration as a function of logarithm of discharge and discharge-squared, seasonal sine and cosine functions, long-term time and time-squared terms, and the logarithm of turbidity (from the continuous water-quality sensors). If a model parameter was not significant ( $p$-value $>0.05$ ), the parameter was excluded from the regression model to avoid overparameterization by excluding variables that did not explain much variation in the concentrations. Models were calibrated for the entire period of record for each watershed through WY 2009. The addition of the parameter logarithm of turbidity to the concentration models was started in WY 2004 and was not included in the WY 1998-2003 load presented in Landers and others (2007). The inclusion of turbidity improved the models by increasing the amount of variation in concentrations that the models explained, likely because turbidity can be a surrogate for suspended sediment and other constituents in the water. Because of maintenance and difficulties in measuring water quality using continuous sensors, there are inevitable 
gaps in the data record. Hence, a second concentration relation without turbidity was modeled to use as a fallback for periods where the turbidity record was missing. A residual analysis was performed to check for outlier concentrations that would affect the fit of the concentration relation, and these outliers were removed so they would not affect model predictions. Loads were estimated for all of the constituents in table 2 except for $\mathrm{SC}$ and turbidity, which are not direct measures of concentration, and TKN, which is used to calculate TN. TSS loads for 2004-09 are updated from those reported in Landers (2013).

\section{Total Suspended Solids Load Estimation Error}

Errors in the estimates for TSS annual loads are calculated because of the importance of TSS as a target performance criterion in the Gwinnett County Watershed Protection Plan. There are many sources of errors, including streamflow measurements, water-quality sample representativeness, laboratory analytical measurements, and load estimation modeling. Horowitz (2003) indicated that suspended-sediment load errors of $\leq \pm 15-20$ percent should be considered relatively accurate for small to large rivers and for quarterly to greater timeframes.

LOADEST calculates both the standard error (SE) and the standard error of the prediction (SEP) of the mean load estimate. The SE represents the variability attributed to parameter uncertainty of the model calibration, while the SEP also includes the effects of random error. Therefore, SEP tends to be larger than SE, but SEP provides a better estimate of the errors between the load estimates and the actual loads. SEP calculations assume that the errors are independent in time (no serial correlation), as serial correlation can result in SEPs underestimating the actual uncertainty in the load estimates (Aulenbach, 2013). The size of error for any given year depends on the actual streamflow and turbidity observed for that year.

In this report, errors are based on the SEP and are expressed as 95th percent lower and upper confidence intervals. The percentage of the confidence interval represents the percentage of load estimates that are expected to reliably be within that confidence interval. The errors are assumed to follow a normal probability distribution, and as load models were created in logarithmic space, the upper 95th percent confidence interval will be larger than the lower 95th percent confidence interval. Landers and others (2007) previously reported LTTM program watershed load errors as SEs, which represent the error within \pm one standard deviation of the mean and a confidence interval of about 68.3 percent; whereas the 95th percent confidence interval represents the error within \pm 1.96 standard deviations. Hence, the reported range of 95 th percent confidence intervals will be almost twice as large as the reported range of SEs. This difference needs to be accounted for when comparing the errors between this report and Landers and others (2007).

LOADEST provides estimates of the 95th percent confidence intervals on an annual basis. Error estimates are complicated by the fact that loads are estimated using two models - one that includes turbidity and one that does not. The annual error in loads of the combined models was estimated by weighting the annual errors of the two models by the fraction of annual runoff each of the models contribute to the annual load. The lower $\left(C I_{95 \% \text { Lower }}\right)$ and upper $\left(C I_{95 \% \text { Upper }}\right)$ 95th percent confidence intervals are estimated using equations 2 and 3, respectively.

$$
\begin{aligned}
& C I_{95 \% \text { Lower }}=L_{\text {Total }}-\left[\left(L_{T Q}-C I_{95 \% \text { Lower }(T Q)}\right) * R F_{T Q}\right. \\
& \left.+\left(L_{Q}-C I_{95 \% \text { Lower }(Q)}\right) * R F_{Q}\right]
\end{aligned}
$$

$$
\begin{aligned}
& C I_{95 \% \text { Upper }}=L_{\text {Total }}+\left(C I_{95 \% \text { Upper(TQ) }}-L_{T Q}\right) * R F_{T Q} \\
& +\left(C I_{Q 95 \% \text { Upper }(Q)}-L_{Q}\right) * R F_{Q}
\end{aligned}
$$

where $L_{\text {Total }}$ is the total annual load; $L$ is annual load; $R F$ is the annual runoff fraction for that model's load; and $T Q$ and $Q$ represent the turbidity-flow and flow-only models, respectively. Confidence intervals for yields were then calculated from the load estimate confidence intervals.

\section{Watershed Characteristics}

Gwinnett County is located in north-central Georgia, about 15 miles northeast of Atlanta (fig. 1). The county, which encompasses about 436 square miles, is located in the Piedmont physiographic province. The geology of the county is a mixture of complex and varied metamorphic rocks (U.S. Geological Survey, 2014).

Gwinnett County is composed predominantly of headwater streams that drain into one of three major rivers: the Chattahoochee, the Ocmulgee, and the Oconee. The Eastern Continental Divide, which separates drainages that flow into the Gulf of Mexico from those that flow into the Atlantic Ocean, runs approximately northeast-southwest across the northwestern portion of the county. Five study watersheds (Richland Creek, Level Creek, Suwanee Creek, Crooked Creek and North Fork Peachtree Creek) are northwest of the divide and lie within the Apalachicola-Chattahoochee-Flint River Basin, which flows into the Gulf of Mexico. The remaining seven study watersheds (Yellow River, Alcovy River, Big Haynes Creek, Brushy Fork Creek, No Business Creek, Wheeler Creek, and Apalachee River) lie within the AltamahaOcmulgee-Oconee River Basin, which flows into the Atlantic Ocean (fig. 3).

\section{Watershed Basin Slope}

Landers and others (2007) showed that basin slope has a direct effect on stream hydrology and water quality in Gwinnett County. Altitudes in Gwinnett County range from 720 to 1,290 feet above North American Vertical Datum of 1988 (NAVD 88; fig. 4). Land-surface slope across Gwinnett 


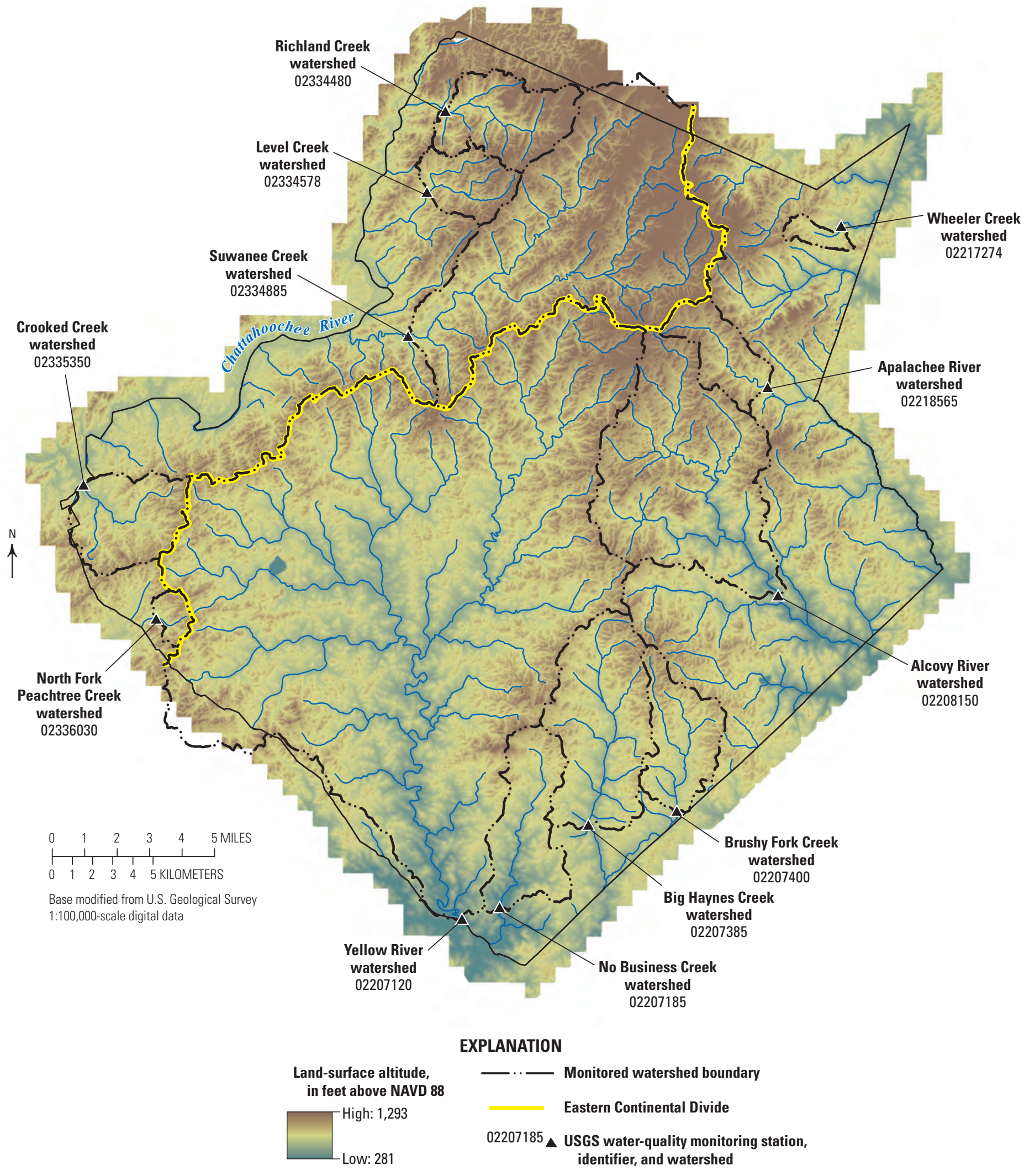

Figure 3. Land-surface altitude for Gwinnett County, Georgia. [Altitude data from aerial light detection and ranging (lidar; laser-radar) survey from Gwinnett County Department of Public Utilities, unpub. data, 2009] 


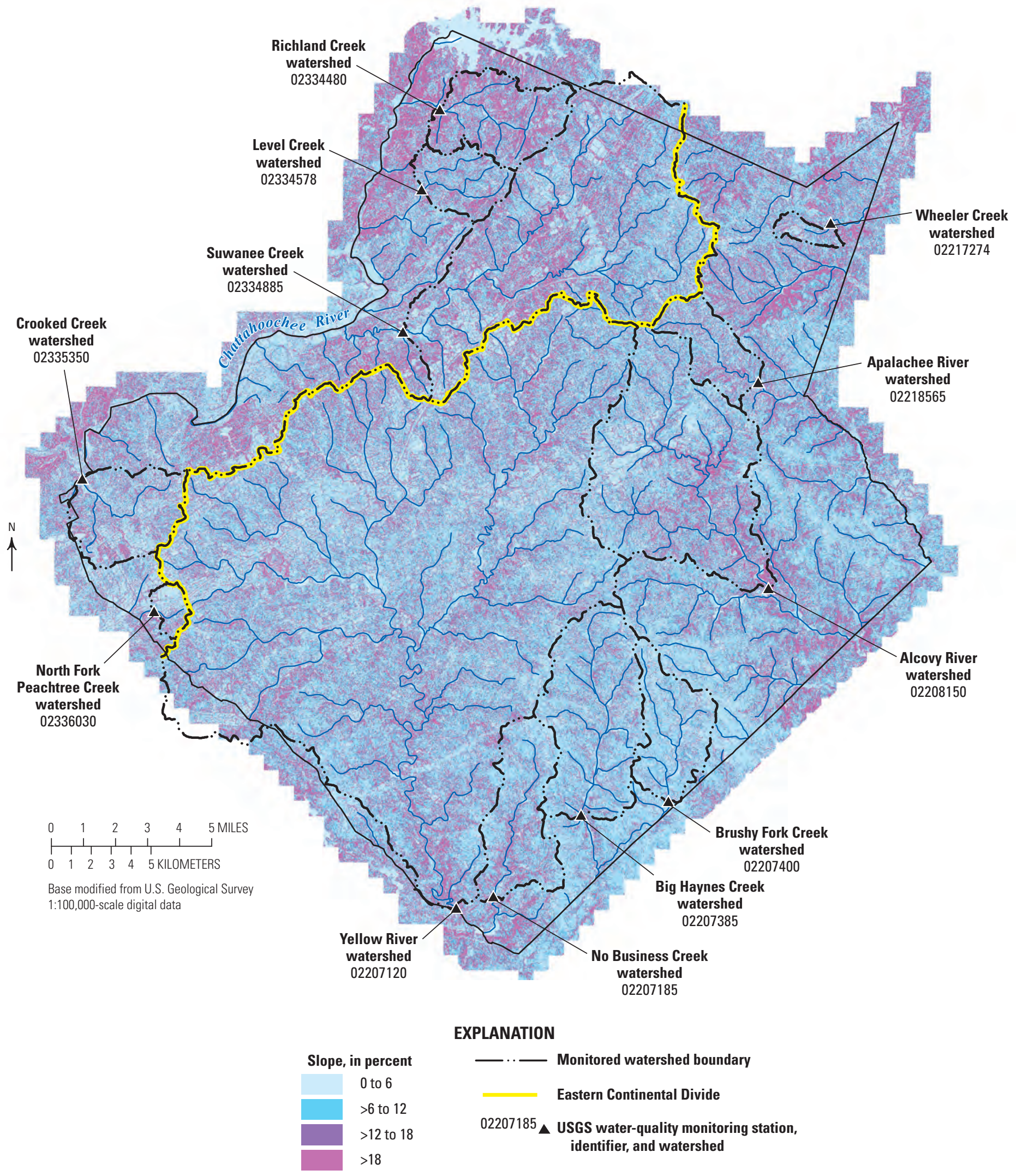

Figure 4. Land-surface slope for Gwinnett County, Georgia. [Derived from altitude data from Gwinnett County Department of Public Utilities, unpub. data, 2009] 
County ranges to greater than 18 percent; the higher slopes generally are in the northern portion of the county within the Apalachicola-Chattahoochee-Flint River Basin (fig. 4). The average basin slope of the 12 LTTM program watersheds is 9.0 percent, with the Richland Creek watershed having the steepest slope of 13.8 percent and the Brushy Fork Creek watershed having the shallowest slope of 5.3 percent (fig. 5). The assessment of basin slope for the 12 watersheds is consistent with the initial determination from Landers and others (2007) for the initial six watersheds in the LTTM program.

\section{Population}

Gwinnett County is a densely populated, suburban county of the Atlanta metropolitan area. Gwinnett County has undergone rapid population growth from about 1980 to 2010, and land use has changed from what was once predominantly agriculture and forest to a highly developed area. Both land-use changes and population growth can make watershed management more challenging, because increases in impervious areas typically are associated with increased storm runoff and decreased base flow, and population growth increases the demands on the water supply and for wastewater treatment.
The population density in Gwinnett County in 2009 was about 789,000, about 1,840 people per square mile (fig. 6); whereas, the national average in 2010 was about 87.4 people per square mile (U.S. Census Bureau, 2011). The population density is greater in the western portion of the county and along the major roadways. Average watershed population densities in 2009 ranged from about 880 people per square mile in the Wheeler Creek watershed to about 4,200 people per square mile in the North Fork Peachtree Creek watershed (fig. 7).

Population in Gwinnett County increased by about 195,000 people from 1996 to 2003 (the 7-year period reported by Landers and others [2007]), a 41 percent increase (fig. 8). From 2003 to 2009 (the 6-year period summarized in this report), the population increased by about 113,000 (a 17 percent increase from 2003). The rate of population growth decreased from about 27,900 people per year from 1996 to 2003 to about 18,900 people per year from 2003 to 2009 . Annual county population estimates are from a combination of data from the U.S. Census Bureau (U.S. Census Bureau, 2004, 2011) and Gwinnett County State of the County annual reports (Gwinnett County, Georgia, 2004, 2005, 2006, 2007, 2008, 2009, 2010, 2012, 2013, 2014).

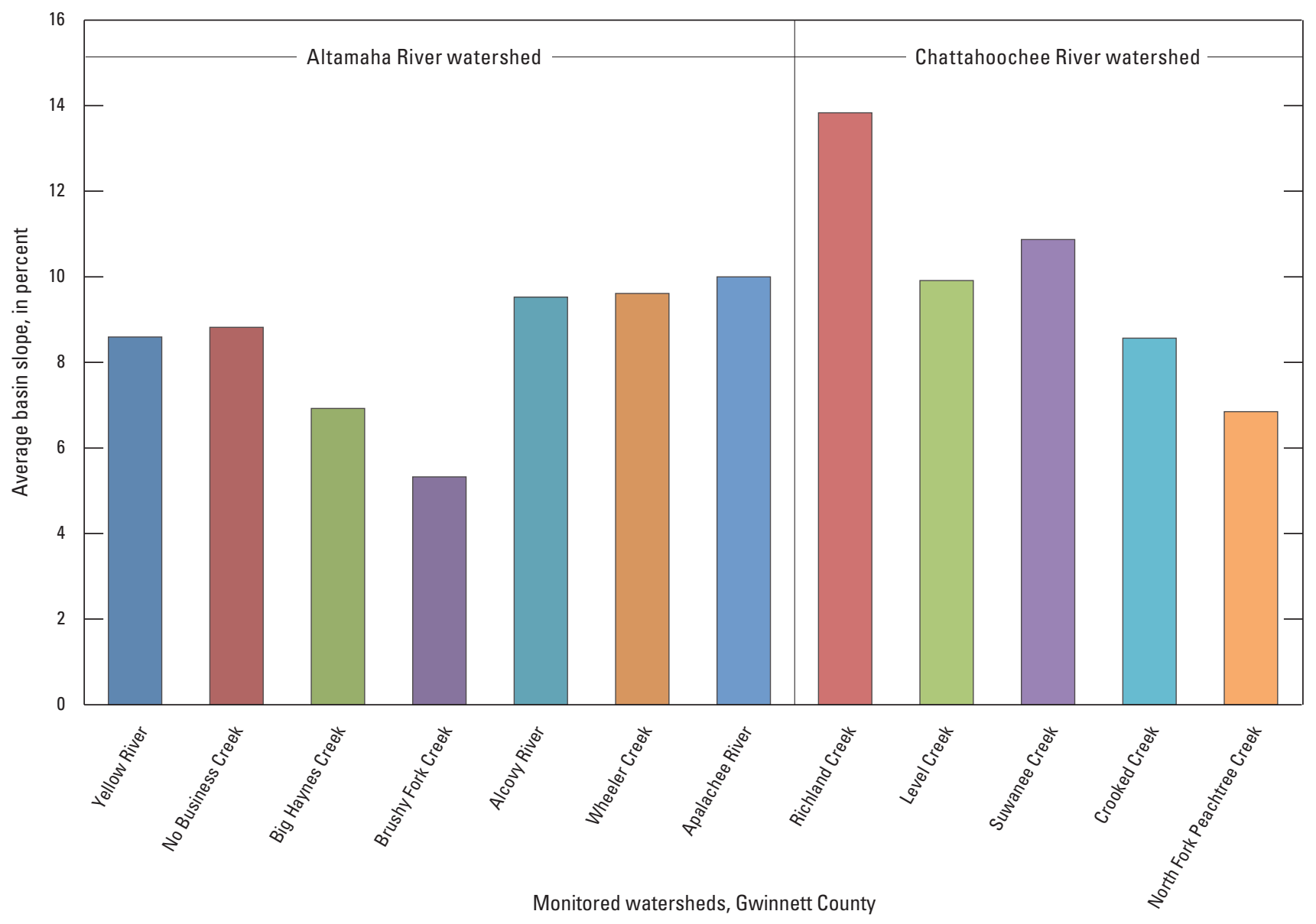

Figure 5. Average basin slope of the 12 monitored watersheds in Gwinnett County, Georgia. [Derived from altitude data from Gwinnett County Department of Public Utilities, unpub. data, 2009] 


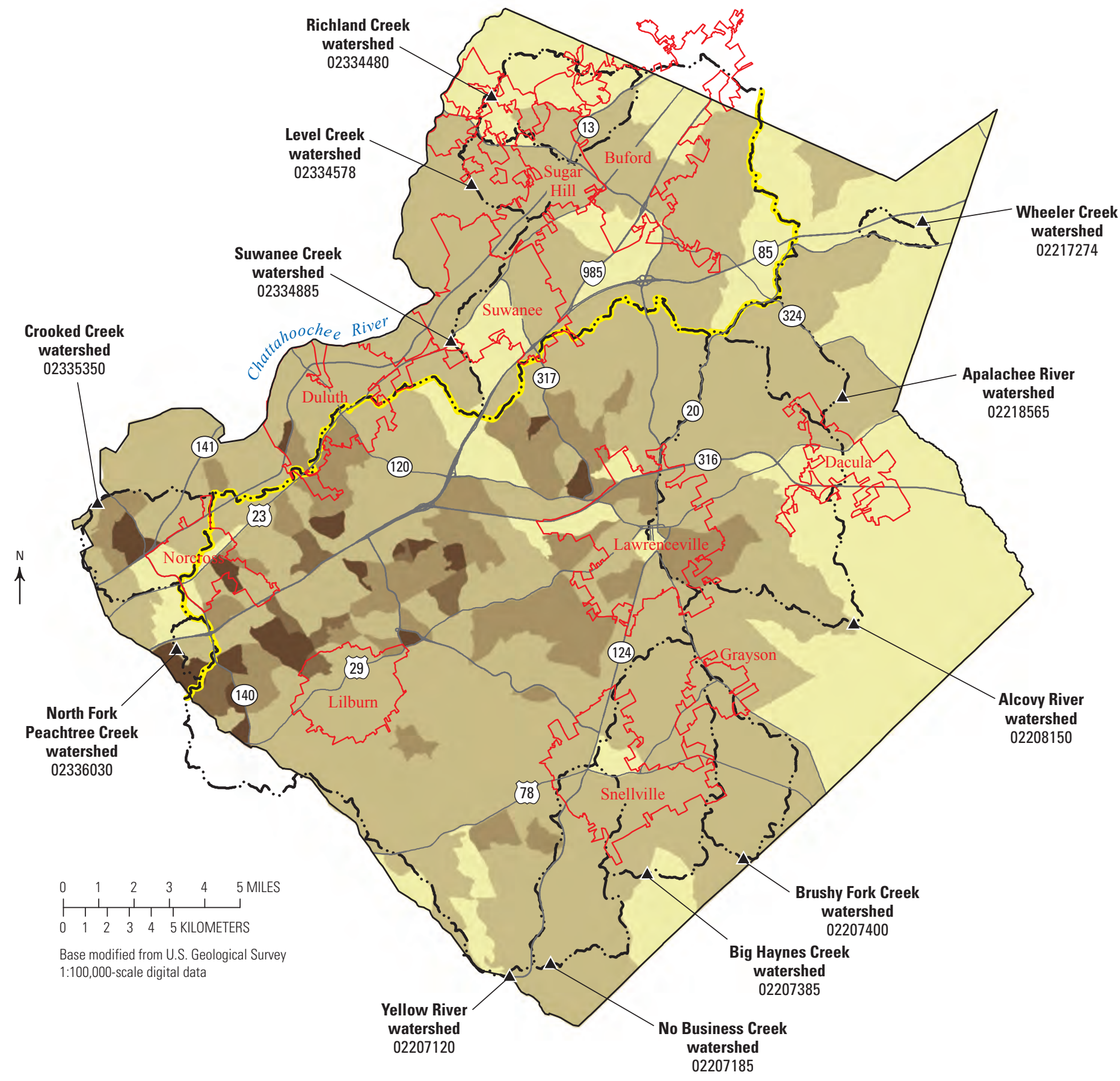

EXPLANATION

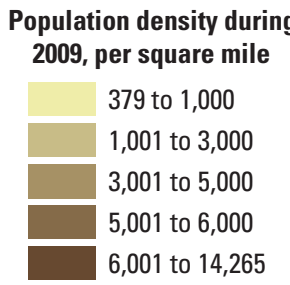

Figure 6. Population density for Gwinnett County, Georgia, 2009. [Data from American community survey 5-year estimates of 2006-10 block group data, U.S. Census Bureau, 2012] 


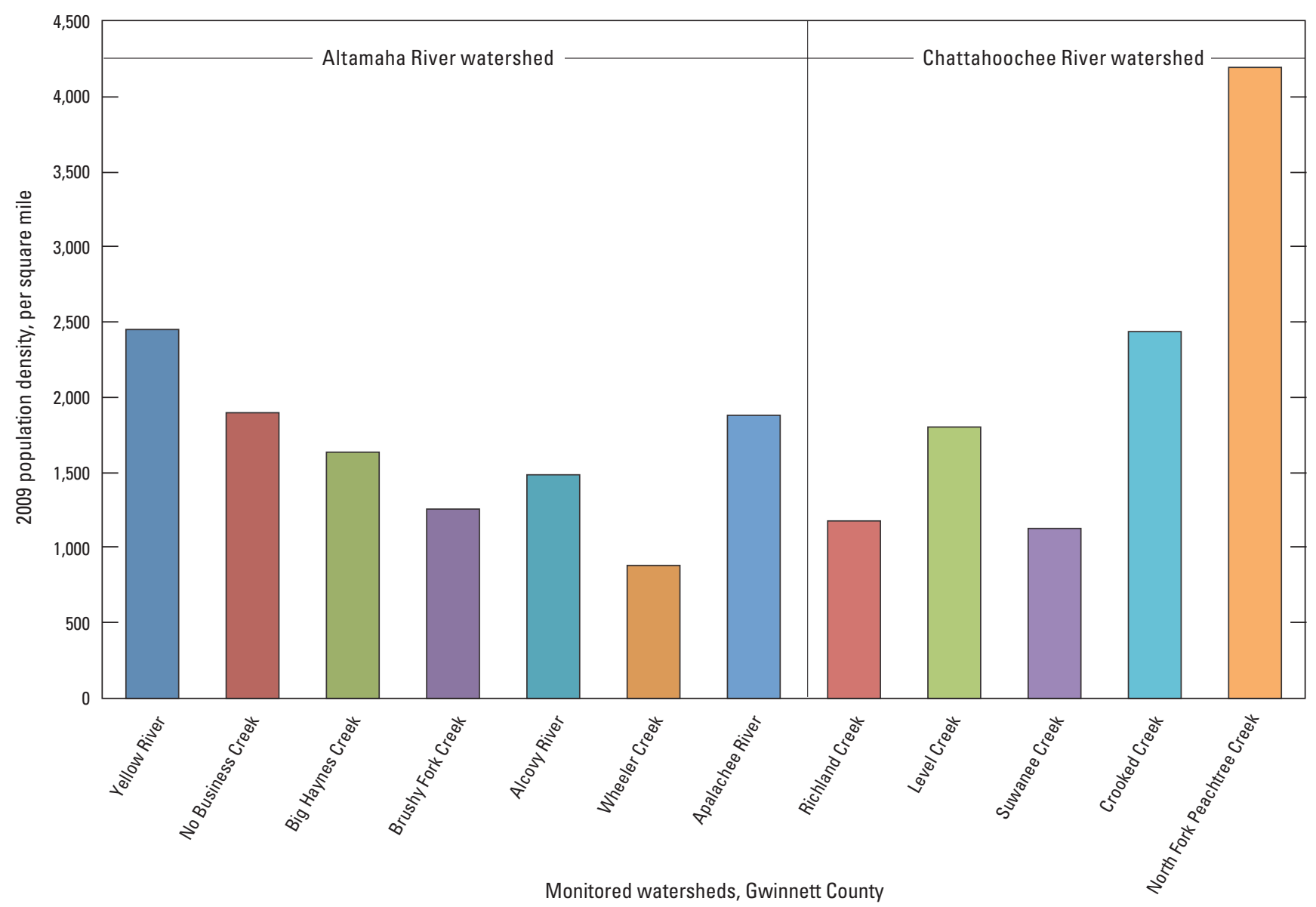

Figure 7. Population density for the 12 monitored watersheds in Gwinnett County, Georgia, 2009. [Derived from American community survey 5-year estimates of 2006-10 block group data, U.S. Census Bureau, 2012] 

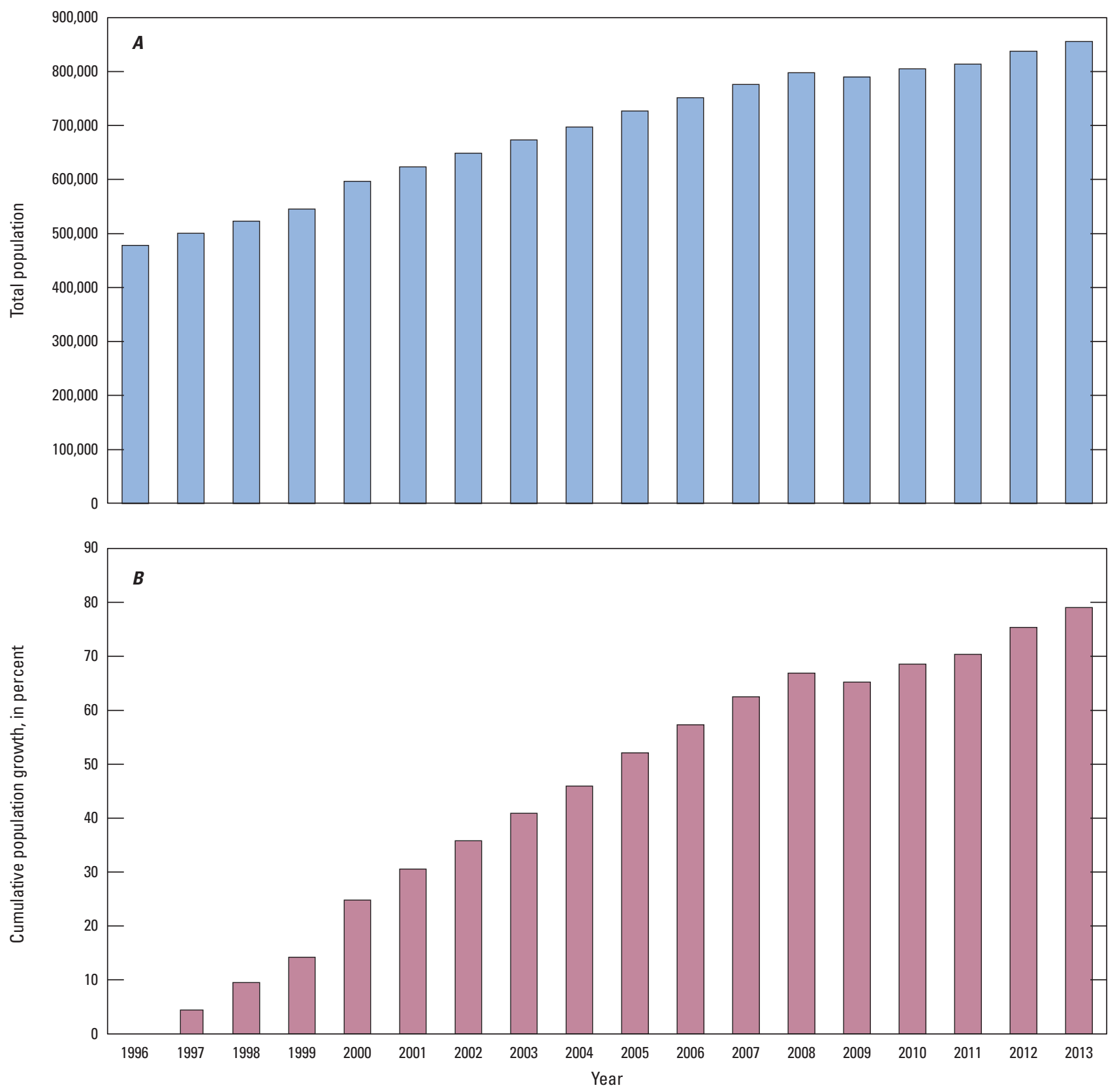

Figure 8. $A$, total population by year and $B$, population growth for Gwinnett County, Georgia, 1996-2013. [Data from U.S. Census Bureau $(2004,2011)$ and Gwinnett County, Georgia $(2004,2005,2006,2007,2008,2009,2010,2012,2013,2014)]$ 


\section{Land Use and Changes in Impervious Area}

Land use and impervious area are summarized for the 12 LTTM program watersheds in table 3; data are based on the Atlanta Regional Commission 2009 land use geographic information system (GIS) dataset (Atlanta Regional Commission, 2010). Individual land-use categories have been grouped into six categories: high density, low density, estate/park, transportation/utilities, undeveloped/water, and other. Land use varies greatly among watersheds. For example, North Fork Peachtree Creek and Crooked Creek watersheds have much higher high-density land use, 63.74 and 44.79 percent of the watershed, respectively, relative to the other watersheds, which have high-density land-use areas of less than 21 percent.

Impervious area has been determined to be an important factor affecting the rainfall-runoff relations in many studies (for example, Leopold, 1968; Hollis, 1975; Ogden and others, 2011), including areas in Gwinnett County (Landers and others, 2007). Impervious areas reduce infiltration and, hence, groundwater recharge, resulting in lower base flows. Impervious areas also increase runoff rates, resulting in a "flashy" hydrologic response along with higher peak storm discharges that may increase both erosion and transport of land surface, tributary and stream sediments. The percentage of impervious area in the 12 study watersheds ranged from 12.21 percent in the Richland Creek watershed to 52.79 percent in the North Fork Peachtree Creek watershed (table 3; fig. 9). Watershed impervious area is categorized into transportation elements, which include land uses such as roads, parking lots, and driveways, and building elements (fig. 9). On average, about two-thirds of the total impervious area in the watersheds is from transportation elements. High-density land use typically contains a large proportion of impervious area, hence, the strong association between these characteristics. The percentage of impervious area in the watersheds is associated more with high-density land use than with population density (fig. 10).

Table 3. Land use and watershed characteristics for 12 watersheds in Gwinnett County, Georgia, 2009.

[Land-use data from Atlanta Regional Commission, 2010]

\begin{tabular}{|c|c|c|c|c|c|c|c|c|c|c|c|c|}
\hline \multirow[b]{2}{*}{$\begin{array}{l}\text { Station } \\
\text { number }\end{array}$} & \multirow[b]{2}{*}{$\begin{array}{l}\text { Watershed } \\
\text { name }\end{array}$} & \multirow[b]{2}{*}{$\begin{array}{c}\text { Drainage } \\
\text { area }{ }^{1} \\
\text { (square } \\
\text { miles) }\end{array}$} & \multicolumn{6}{|c|}{ Land use (percent) } & \multicolumn{3}{|c|}{$\begin{array}{c}\text { Watershed impervious area } \\
\text { (percent) }\end{array}$} & \multirow[b]{2}{*}{$\begin{array}{c}\text { Slope } \\
\text { (percent) }\end{array}$} \\
\hline & & & 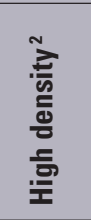 & 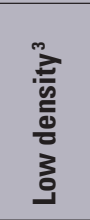 & 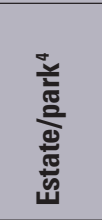 & 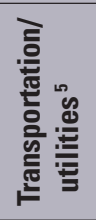 & 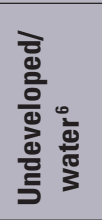 & 㐫 & 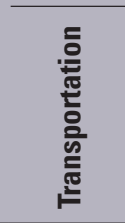 & 뫁 & 흄 & \\
\hline 02207185 & No Business Creek & 10.17 & 13.42 & 64.36 & 18.38 & 0.10 & 3.00 & 0.74 & 12.58 & 5.99 & 18.57 & 9 \\
\hline 02207385 & Big Haynes Creek & 17.34 & 7.46 & 69.71 & 19.37 & 0.05 & 2.07 & 1.35 & 10.24 & 6.40 & 16.64 & 7 \\
\hline 02207400 & Brushy Fork Creek & 8.17 & 9.25 & 47.14 & 30.84 & 0.07 & 7.59 & 4.14 & 9.36 & 5.21 & 14.57 & 5 \\
\hline 02208150 & Alcovy River & 30.76 & 13.71 & 44.29 & 30.95 & 2.68 & 7.06 & 1.04 & 11.01 & 4.19 & 15.21 & 10 \\
\hline 02217274 & Wheeler Creek & 1.31 & 20.24 & 49.29 & 19.71 & 4.75 & 5.98 & 0.00 & 10.05 & 5.88 & 15.92 & 10 \\
\hline 02334578 & Level Creek & 5.08 & 4.90 & 60.57 & 31.16 & 0.00 & 2.84 & 0.00 & 10.31 & 6.33 & 16.63 & 10 \\
\hline 02334885 & Suwanee Creek & 47.26 & 20.54 & 37.18 & 30.02 & 3.36 & 6.96 & 1.07 & 12.53 & 6.38 & 18.91 & 11 \\
\hline 02335350 & Crooked Creek & 8.91 & 44.79 & 39.67 & 7.46 & 4.78 & 3.00 & 0.31 & 24.18 & 12.63 & 36.81 & 9 \\
\hline 02336030 & $\begin{array}{l}\text { North Fork } \\
\text { Peachtree Creek }\end{array}$ & 1.42 & 63.74 & 29.93 & 0.51 & 5.09 & 0.77 & 0.00 & 32.81 & 19.98 & 52.79 & 7 \\
\hline
\end{tabular}

${ }^{1}$ Drainage areas calculated from Atlanta Regional Commission land-use dataset and vary slightly from drainage areas shown in table 1.

${ }^{2}$ High-density land use includes commercial, industrial, schools, religious, quarries, and residential lots with less than 1/4 acre.

${ }^{3}$ Low-density land use includes residential lots sizes greater than or equal to $1 / 4$ acre and less than 5 acres.

${ }^{4}$ Estate/park use includes public and private parks, golf courses, and agricultural lands, and forests.

${ }^{5}$ Transportation/utilities land use includes pervious and impervious areas within the right-of-way for roads, railroads, communications, and utilities.

${ }^{6}$ Undeveloped land use includes landfills, waste dumps, water control structures, and recently cleared transitional land; water land use includes reservoirs and wetlands. 


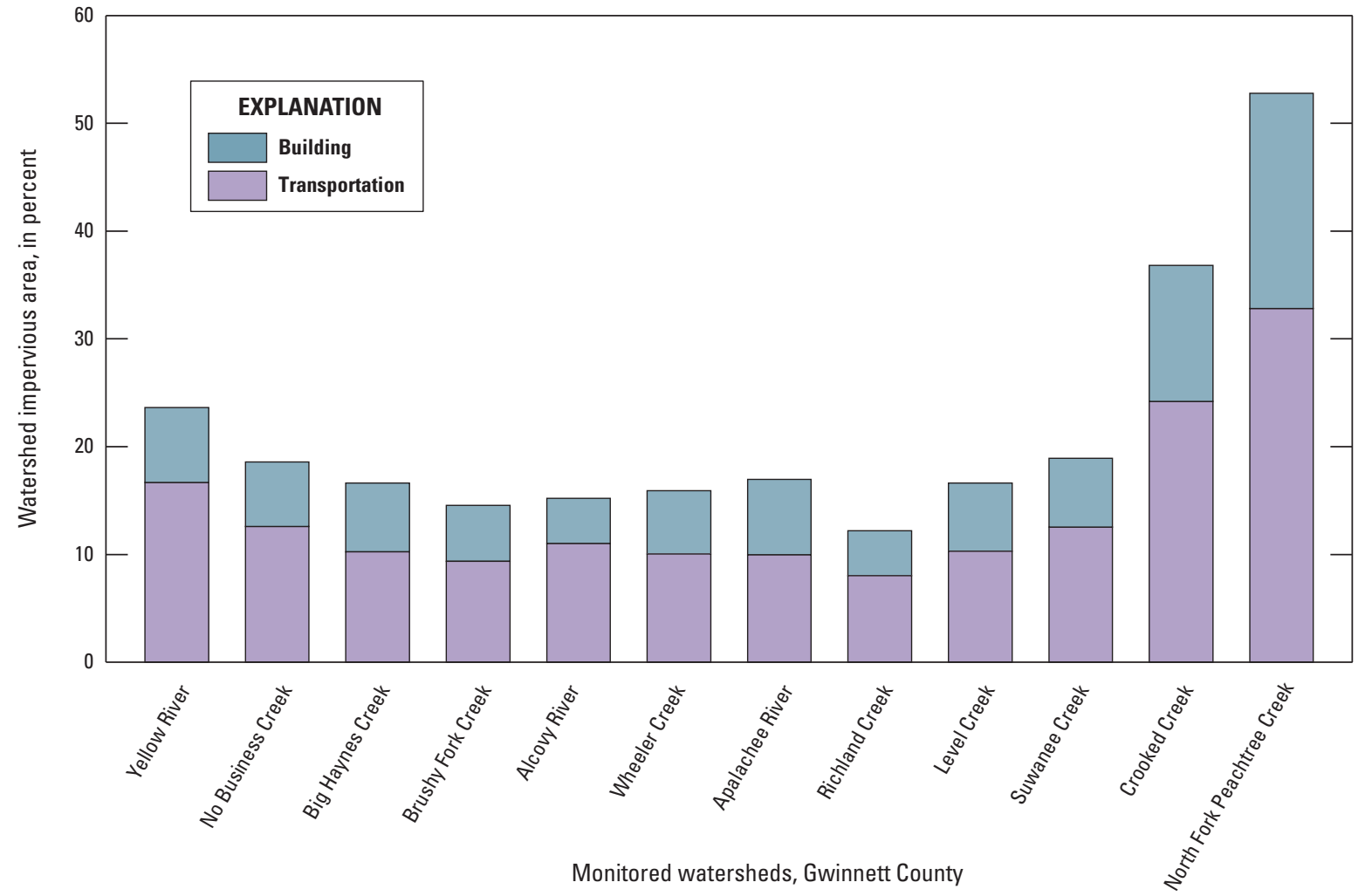

Figure 9. Percentage of watershed impervious area from transportation and building land cover for 12 monitored watersheds in Gwinnett County, Georgia, 2009. [Data from Gwinnett County land coverage data, Gwinnett County Department of Public Utilities, unpub. data, 2009]
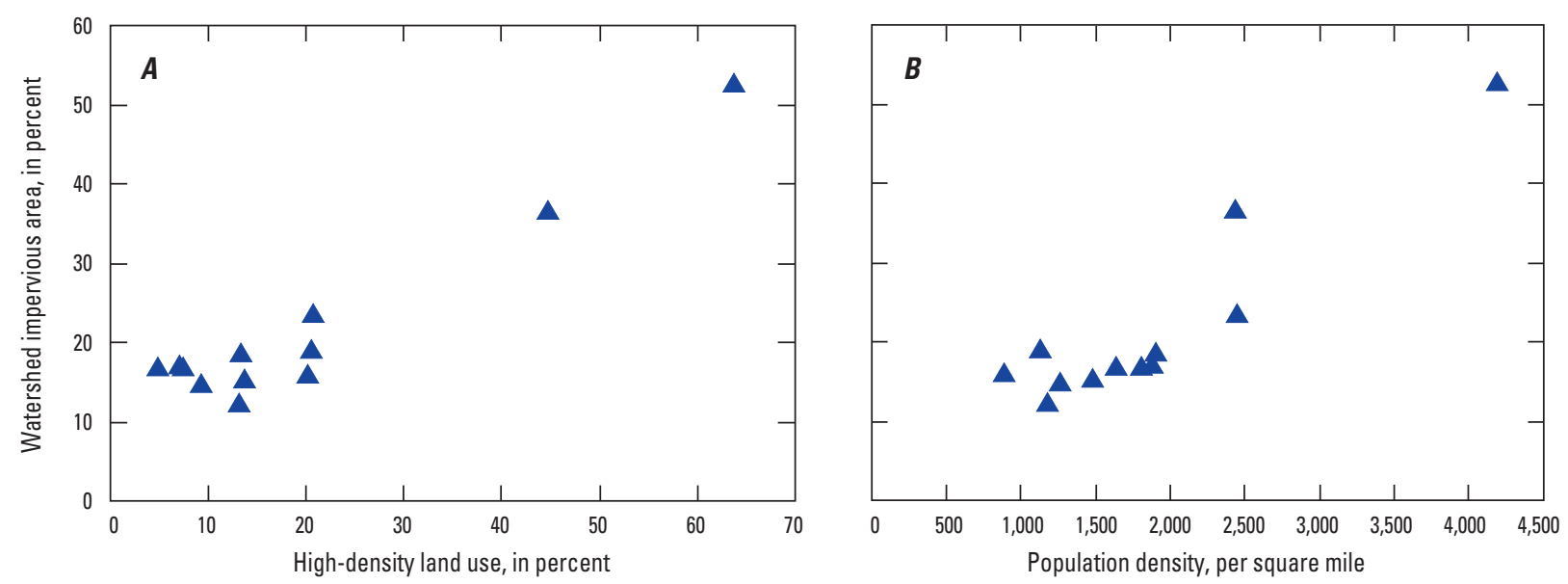

Figure 10. Watershed impervious area as related to $A$, high-density land use and $B$, population density for 12 monitored watersheds in Gwinnett County, Georgia, 2009. [Impervious area and land-use data from Gwinnett County land coverage data, Gwinnett County Department of Public Utilities, unpub. data, 2009; Population data derived from American community survey 5-year estimates of 2006-10 block group data, U.S. Census Bureau, 2012] 
Figure 11 illustrates how the percentage of impervious area has changed over time in the 12 watersheds for the year 2000 and annually from 2005 to 2009 (Gwinnett County Department of Public Utilities, unpub. data, 2009). All 12 watersheds show increases in impervious area over the period. The increases in impervious area from 2000 to 2005 are greater than the increases from 2005 to 2009 . These increases are likely related to development within the watersheds associated with population growth (fig. 8). The two watersheds with the highest percentage of impervious areas, North Fork Peachtree Creek and Crooked Creek, did not change much over the later years, 2005 to 2009. The Wheeler Creek watershed, which had the lowest percentage of impervious area of the 12 watersheds in 2000, has shown the largest increases in the percentage of impervious area over the 2000 to 2009 period. Yellow River, Alcovy River, Apalachee Creek, and Suwanee Creek watersheds also exhibited large increases in percentage of impervious areas over this same period.

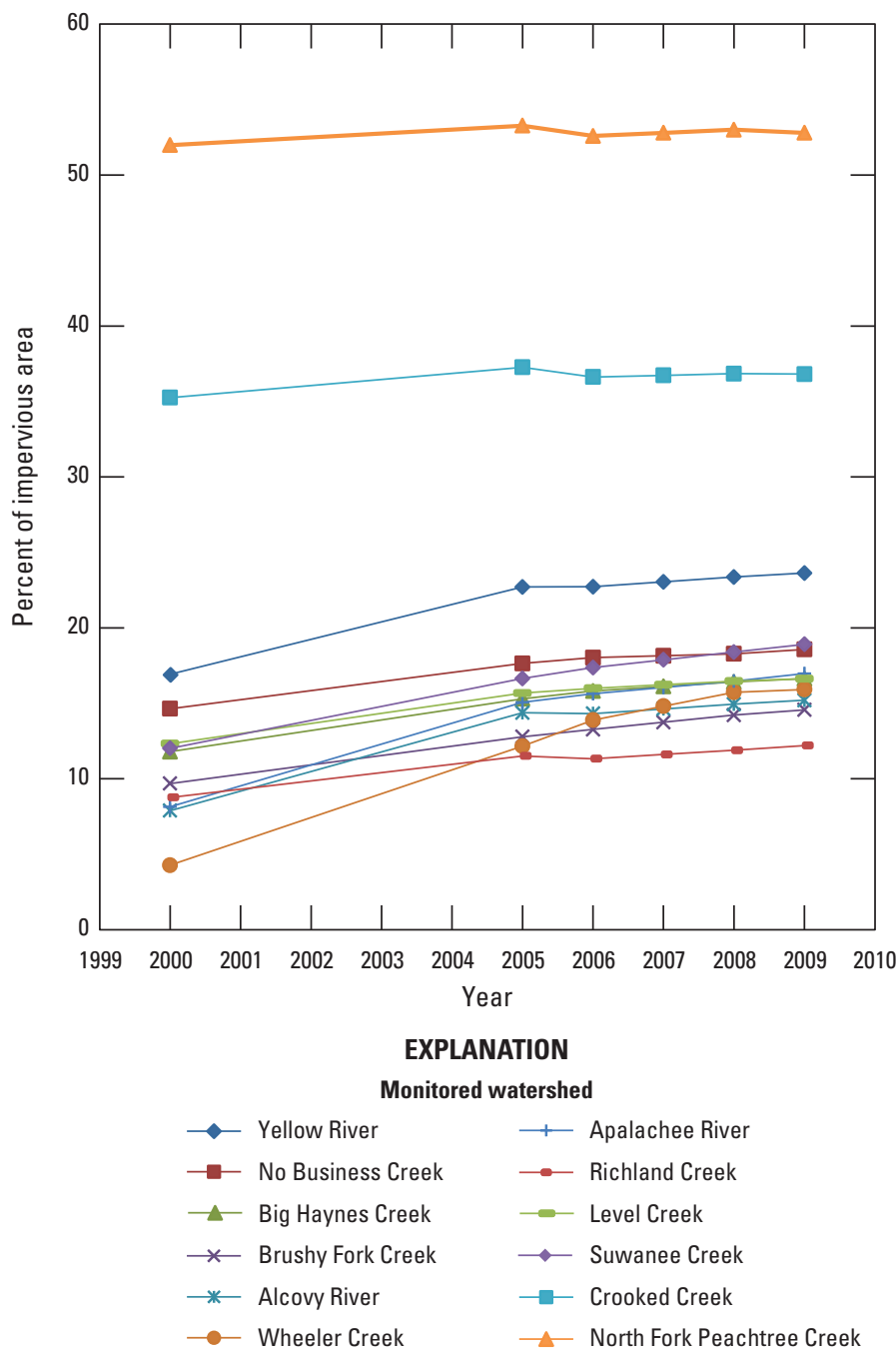

Figure 11. Percentage of impervious area in 12 monitored watersheds in Gwinnett County, Georgia. [Data from Gwinnett County land cover data, Gwinnett County Department of Public Utilities, unpub. data, 2009]

\section{Hydrologic Inputs and Outputs}

The main components of the hydrologic budget for the LTTM program watersheds are precipitation, stream runoff, evapotranspiration, and groundwater storage. Climatic patterns in precipitation, runoff, and evapotranspiration are discussed. Annual precipitation and runoff for the 12 watersheds are presented, and water yields, the percentage of precipitation that results in runoff, are calculated. The effects that the WY 2007 and 2008 drought had on runoff and groundwater storage are discussed.

\section{Climate and Precipitation}

Gwinnett County has a humid, subtropical climate characterized by warm, humid summers and cool, wet winters. Monthly average air temperatures range from 42.2 degrees Fahrenheit $\left({ }^{\circ} \mathrm{F}\right)$ in January to $79.8^{\circ} \mathrm{F}$ in July (1981-2010 thirty-year average for Atlanta Dekalb Peachtree Airport station USW00053863, National Oceanic and Atmospheric Administration, 2014). Mean annual precipitation, is 54.7 inches (1981-2010 thirty-year average for Norcross station USC00096407, National Oceanic and Atmospheric Administration, 2014). Precipitation is fairly evenly distributed throughout the year with the fall having the lowest amount of precipitation. Winter rainstorms are characterized by long duration, evenly distributed, and typically low-intensity frontal systems. In contrast, spring and summer rainstorms are characterized by short duration, unevenly distributed, intense convective thunderstorms. Despite their short duration, the intensity of these rainstorms often result in higher peak streamflows in headwater watersheds than those observed for longer-duration, low-intensity storms, and may result in increased erosion and wash off of constituents. Mean annual evapotranspiration is estimated to account for about 50 to 60 percent of the annual precipitation in the study area (Sanford and Selnick, 2013). The seasonal pattern of evapotranspiration results in declining base flows throughout the growing season (April-September) and progressively increasing base flows from event recharge during the dormant season.

The annual precipitation totals for WYs 2004-09 for the 12 study watersheds are shown in figure 12 and are based on USGS rain gages, co-located with the stream gages at the watershed outlet, and four additional gages within the study area. The precipitation totals represent a spatial average and are not just the precipitation recorded at the gage at each watershed outlet. All precipitation gages were used to interpolate the point precipitation data and create a "surface" with a 50-meter cell size and then the cells within each watershed shape were averaged to estimate the precipitation within the watershed for each year. The average shown for Gwinnett County represents the spatial average of the area within the 12 LTTM program watersheds. The highest annual average precipitation (56.4 inches) was in WY 2009 and the lowest (33.0 inches) was in WY 2007. The variability between 


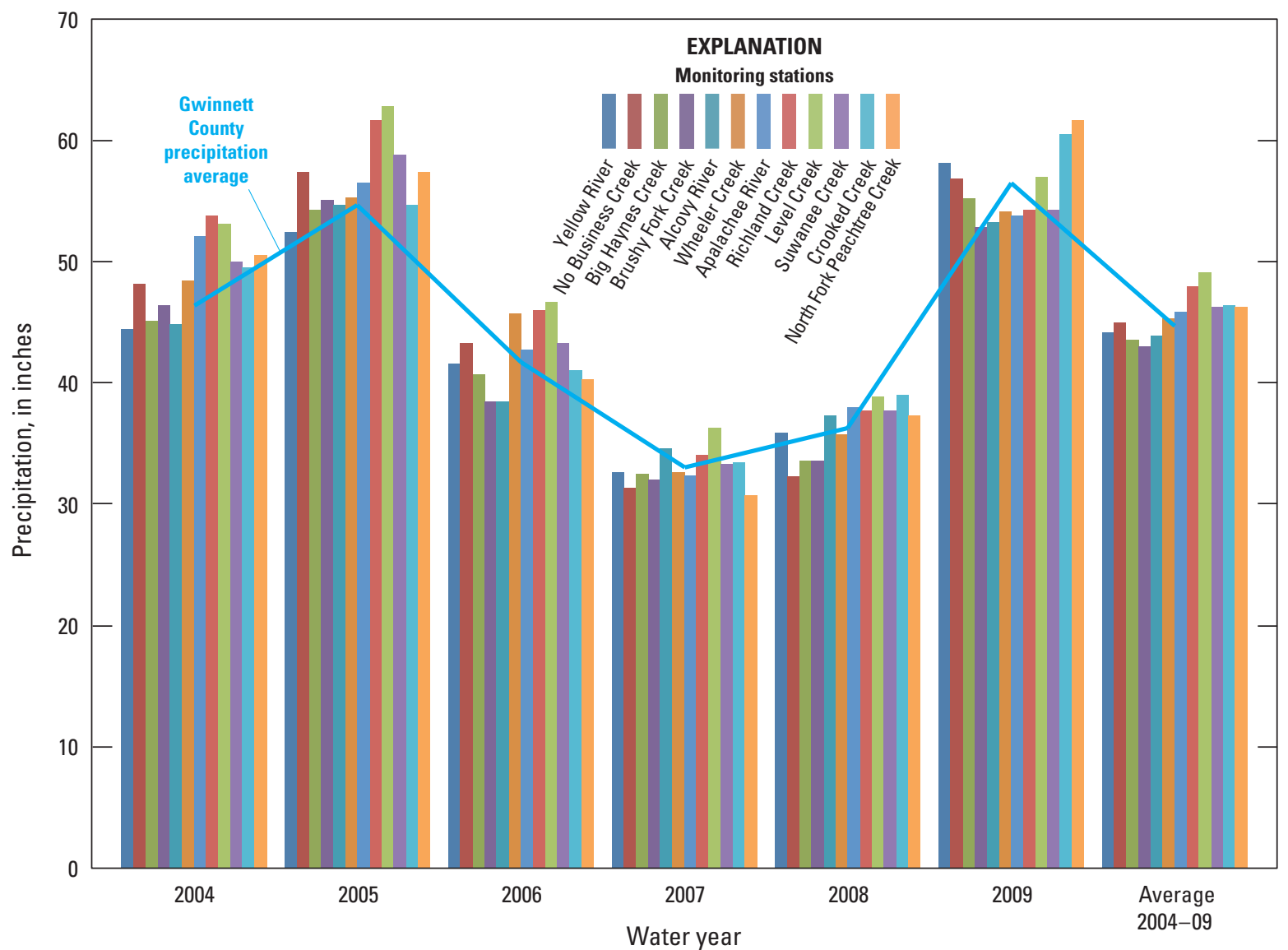

Figure 12. Spatially averaged annual precipitation totals for each of the 12 monitored watersheds in Gwinnett County, Georgia, and the countywide (LTTM program watersheds) average.

watersheds is much smaller than the annual variations. Average annual precipitation for the county was average to slightly above average for two of the years, WYs 2005 (54.7 inches) and 2009 (56.4 inches), and was below average for the other four years when compared to the 1981-2010 thirty-year average for the Norcross weather station (54.7 inches). During the two-year drought, WYs 2007 and 2008, average annual precipitation was 21.7 and 18.5 inches below normal, respectively. The U.S. Drought Monitor publishes weekly maps classifying the severity of droughts across the United States (U.S. Drought Monitor, 2014a and 2014b). On the basis of these maps, the drought conditions in Gwinnett County were classified as (1) severe, (2) extreme, and (3) exceptional for 5,12 , and 5 weeks, respectively, in WY 2007, and for 5, 30, and 12 weeks, respectively, in WY 2008. Although WY 2009 precipitation totals were somewhat above normal, an extreme rainfall-runoff event in September 2009 resulted in historic high flows at a majority of the 12 LTTM program stations. Overall, precipitation for WYs 2004-09 was about 18 percent lower than the 30-year average for Norcross, Georgia.

The average annual precipitation contour map graphically depicts how precipitation varies with geographical location within Gwinnett County (fig. 13). The precipitation contours were generated from data collected at LTTM program monitoring stations for the period of record through 2009. Average precipitation is highest in the northern part of the county where altitudes are the highest (fig. 3) and are lowest in the center of the county. Variability in precipitation is due to factors such as topography (McCrary, 2011), the variable distribution of precipitation from conductive thunderstorms, and proximity to urban heat islands (Bornstein and Lin, 2000). It is important to consider the variations in precipitation among the 12 LTTM program watersheds when comparing discharge and water quality. 


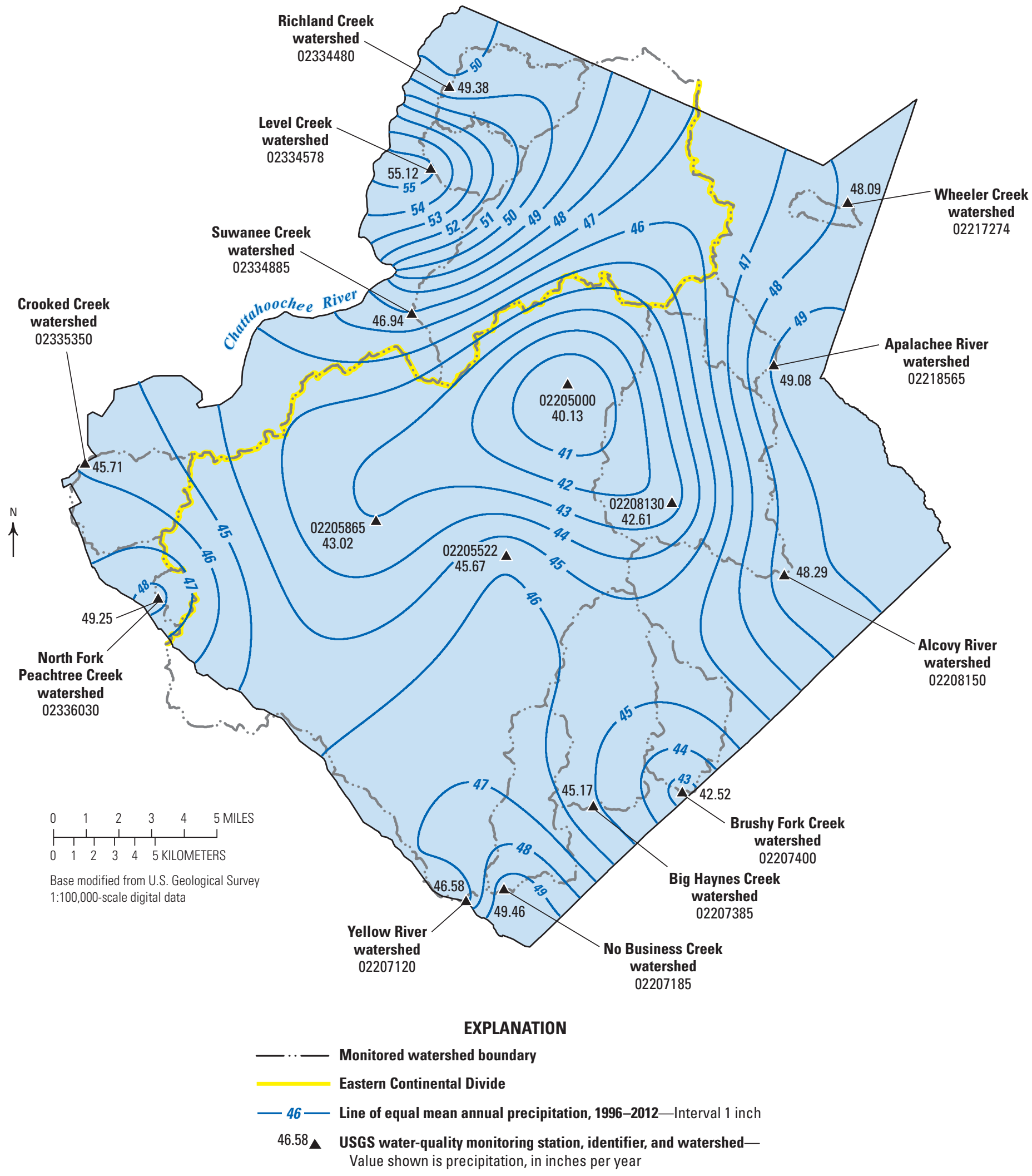

Figure 13. Average annual precipitation for Gwinnett County, Georgia, and the 12 monitored watersheds. 


\section{Annual Runoff and Water Yields}

Annual runoff is the volume of streamflow from the watershed for a given year. Annual runoff is expressed as depth in inches (the volume of runoff divided by the area of the watershed) to allow for comparison between watersheds with different sized drainage areas and to make comparisons with annual precipitation easier. The overall pattern in annual runoff (fig. 14A) follows the general pattern in annual precipitation (fig. 12), but the ongoing effects of the drought can be observed. In the second year of the drought, WY 2008, annual precipitation was slightly higher than the previous year, but annual runoff continued to decline. Although WYs 2005 and 2009 had similar amounts of precipitation, WY 2009 had much lower runoff because a larger portion of precipitation recharged (replenished) groundwater storage instead of resulting in runoff. The variations in annual runoff are pronounced, with annual runoffs about half as much during the two drought years, WYs 2007 and 2008, as during WY 2005, an average precipitation year. In most years, runoff was higher in the Yellow River, Crooked Creek, North Fork Peachtree Creek, and Richland Creek watersheds and does not appear to be associated with higher precipitation for those watersheds (figs. 12 and 13).

Water yield is the portion of precipitation that results in runoff as opposed to being evapotranspired or resulting in changes in groundwater storage within the watershed. Annual water yield is calculated as annual runoff divided by annual precipitation, expressed as a percentage. Water yields are higher in wetter years, when a greater percentage of precipitation results in runoff as opposed to being evapotranspired and recharging groundwater storage. Water yields decreased in successive years of the drought, WYs 2007 and 2008, even though precipitation was fairly similar during those 2 years. Declining groundwater storage during the drought resulted in decreasing stream base flows, and a larger portion of precipitation in the second year of the drought was evapotranspirated instead of recharging the groundwater.

Water yields for the WY 2004-09 period are highest for the North Fork Peachtree Creek (62.1 percent), Crooked Creek (51.9 percent), Richland Creek (48.8 percent), and Yellow River (48.5 percent) watersheds and is lowest in the Level Creek watershed (36.4 percent; fig. 14B). High water yields in the North Fork Peachtree Creek, Crooked Creek, and Yellow River watersheds are likely related to impervious areas (fig. 9; table 3), because these three watersheds have the three highest percentages of impervious areas of the 12 watersheds, 52.79, 36.81 , and 23.63 percent of their watershed areas, respectively. Richland Creek high water yields are likely the result of having the highest basin slope of any of the 12 watersheds (13.8 percent; fig. 5; table 3). Interestingly, annual water yields for the Richland Creek watershed during the 3 years with the lowest precipitation, WYs 2006-08, were higher than all but one watershed, while in more average years, water yields were not notable relative to the other watersheds. This finding appears to indicate that the effect of high basin slope in this watershed is more pronounced on water yield during dry conditions when runoff is reduced. 

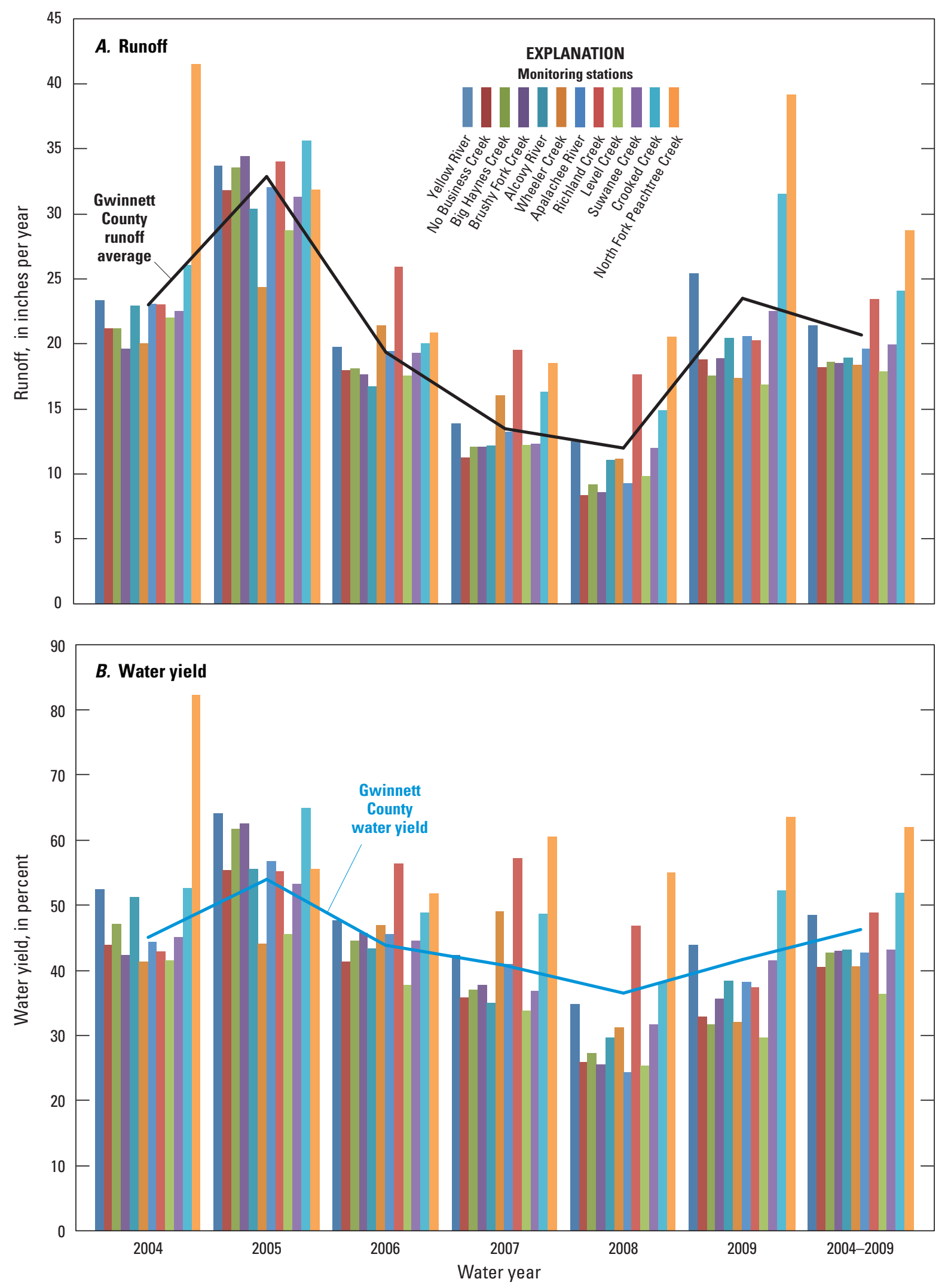

Figure 14. $A$, annual runoff totals and $B$, annual water yields for each of the 12 monitoring stations in Gwinnett County, Georgia. Gwinnett County average represents the spatial average of the area of the 12 monitored watersheds. 


\section{Surface-Water Quality}

Patterns in continuous water-quality monitoring data for specific conductance (SC) and turbidity and their relation to other water-quality constituents were assessed. Statistical summaries of 13 measured or calculated constituents are provided for each of the 12 watersheds. Comparisons are made between base-flow and storm-composited concentrations.

\section{Continuous Water-Quality Monitoring}

Water-quality monitors were installed at all gages to continuously measure water temperature, SC, and turbidity. These continuous water-quality data are used to assess relations with constituents analyzed from base-flow and stormflow samples. For example, SC is related to the type and concentration of dissolved constituents in water and, thus, is a useful surrogate for total dissolved solids or other dissolved constituents. Specific conductance typically varies inversely with discharge - a process referred to as dilution - at the 12 LTTM program stations (fig. 15). Dilution is a commonly observed relation that occurs for many dissolved constituents when during stormflow there is a larger proportion of dilute water from precipitation runoff and shallow flow paths, compared to base-flow concentrations, contributing to discharge. This is not always the case, because some dissolved constituents are mobilized and transported during higher discharges.
Specific conductance varied by watershed area, with larger watersheds having higher mean daily values typically between 100-300 microsiemens per centimeter $(\mu \mathrm{S} / \mathrm{cm})$ at 25 degrees Celsius, and the smaller watersheds having lower values typically between $50-100 \mu \mathrm{S} / \mathrm{cm}$. Mean daily SC ranged from $9 \mu \mathrm{S} / \mathrm{cm}$ at Brushy Fork Creek watershed to $651 \mu \mathrm{S} / \mathrm{cm}$ at North Fork Peachtree Creek watershed. The high mean daily SC at North Fork Peachtree Creek was observed after a snowstorm and was attributed to snowmelt containing road salts.

Turbidity is an optical water-quality property related to the amount of light scattered or absorbed by suspended and dissolved matter and is a good surrogate for suspended sediment. Turbidity can also be a surrogate for a wide range of other constituents, because certain pollutants, such as heavy metals, pesticides, and fecal coliform, adhere to suspendedsediment particles. The U.S. Environmental Protection Agency (2010) lists sediment and other solid-phase constituents as some of the most common sources of impairment in Georgia streams. Good relations were observed during this study between turbidity and many of the water-quality constituents measured during base-flow and stormflow sampling. For example, relations for suspended sediment, total zinc, and total suspended solids are shown for the Yellow River Watershed (fig. 16). Because turbidity is continuously monitored and is highly related to many of the water-quality constituents analyzed as part of this program, turbidity was included as a possible explanatory variable for the concentration models used to estimate loads.

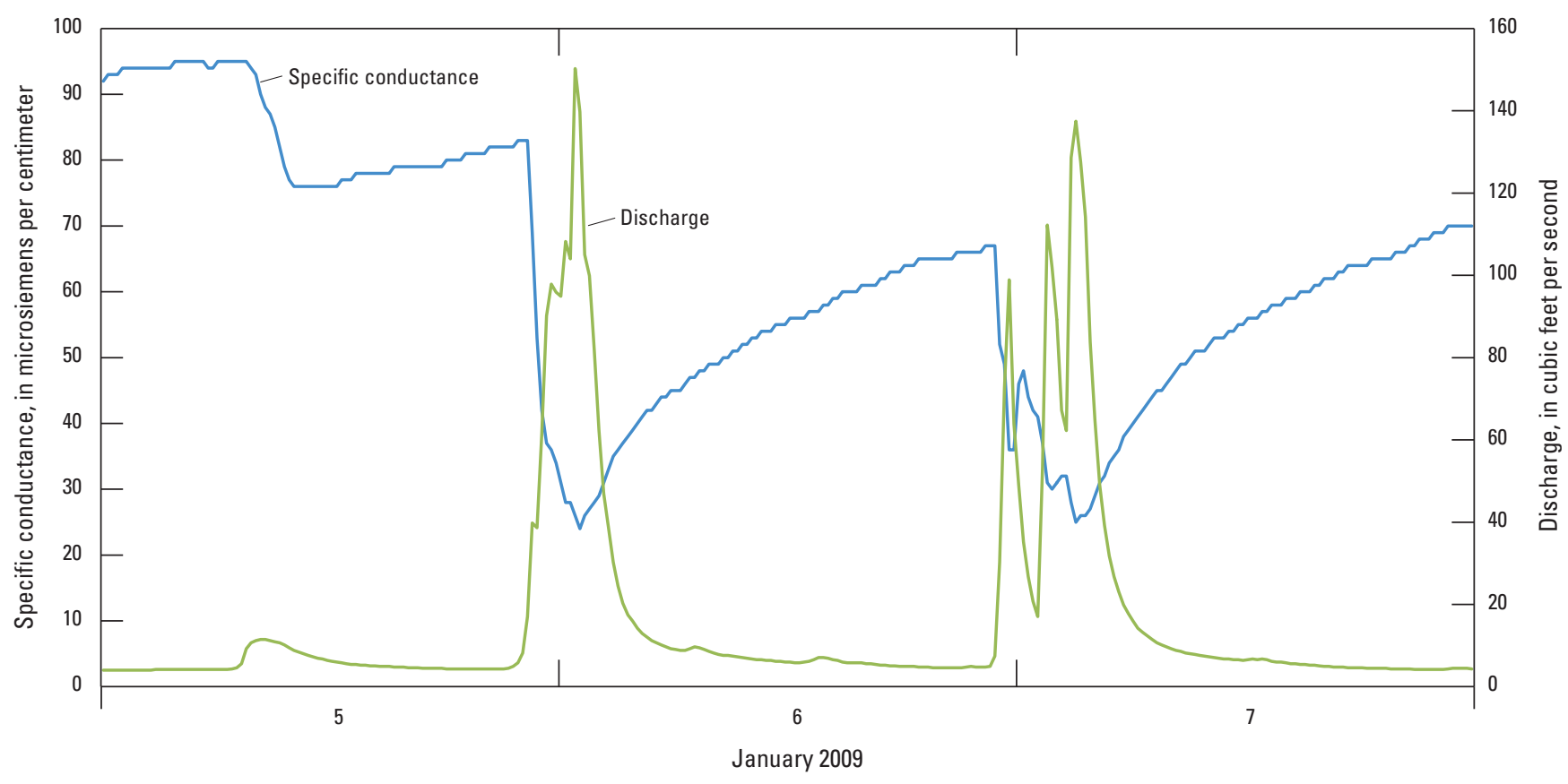

Figure 15. Dilution effects of specific conductance and discharge at station 02336030, North Fork Peachtree Creek near Doraville, Georgia, January 5-7, 2009. 
Turbidity is the expression of the optical properties of liquid that causes light rays to be scattered rather than transmitted in straight lines through a sample. Turbidity, which can make water appear cloudy or muddy, is caused by the presence of suspended and dissolved matter and microscopic organisms (ASTM International, 2003).

Turbidity, measured in formazin nephelometric units (FNU), is continuously monitored at 15-minute intervals and reported in near real-time for all 12 stations.

The direct correlation between turbidity and many of the analyzed constituents is primarily due to the analyte's adsorption to the sediment particles, or because the constituent concentrations vary similarly to variations in sediment concentrations, by similar sources as the sediment being transported. All regression equations used in the estimation of annual loads were evaluated for relations between the continuously monitored water-quality constituents, specific conductance and turbidity, discharge, season, and time. Turbidity was consistently found to be a strong explanatory variable and was included whenever statistically significant.
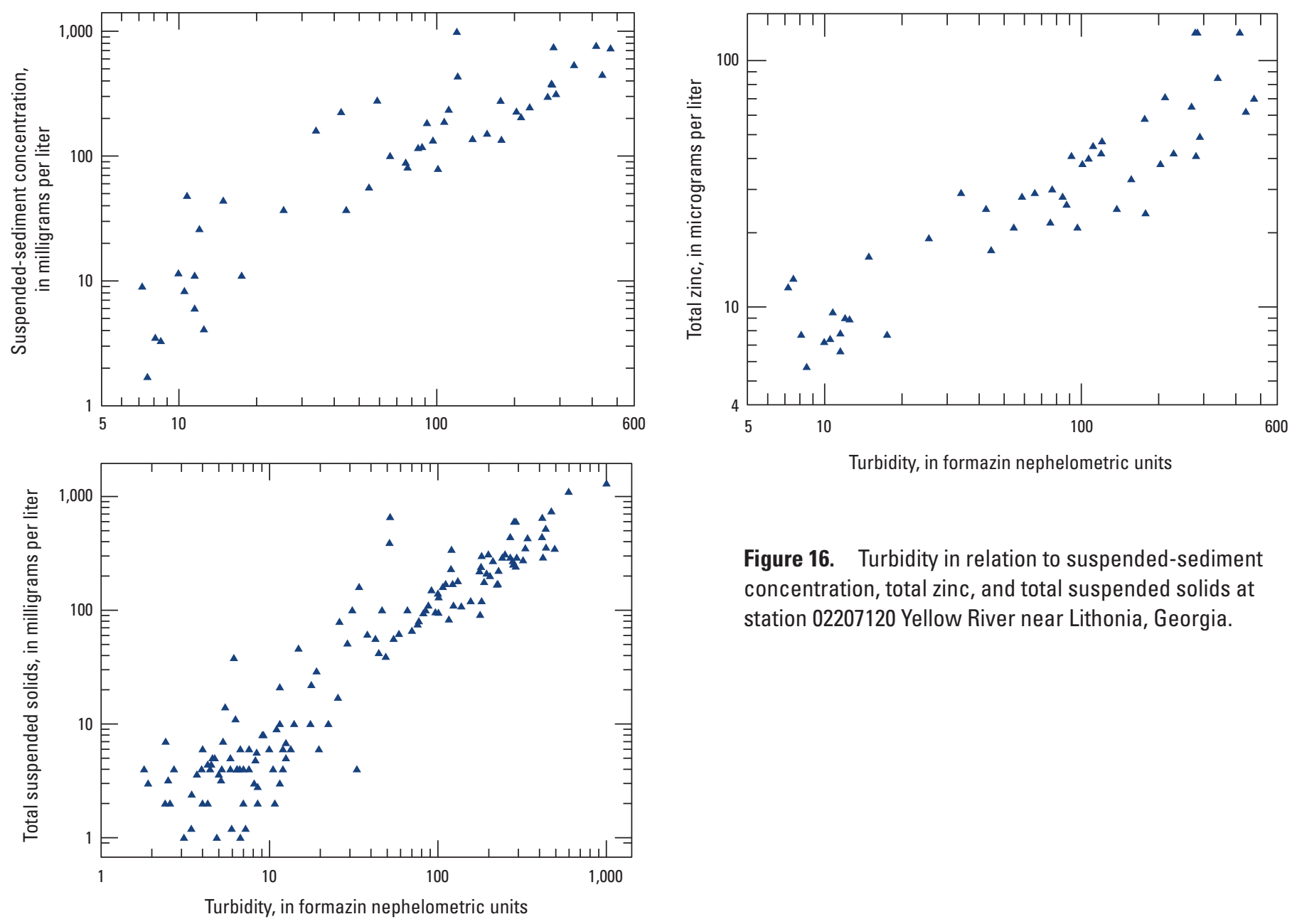

Figure 16. Turbidity in relation to suspended-sediment concentration, total zinc, and total suspended solids at station 02207120 Yellow River near Lithonia, Georgia. 


\section{Base-flow and Stormflow Water Quality}

Statistical summaries of the water-quality sample concentrations for 13 field and laboratory constituents (table 2) are provided by watershed in appendix tables 1-1 through 1-12. Graphical summaries for the 13 constituents in table 2 for both base-flow and stormflow conditions are shown in figure 17.

Specific conductance typically varied between 50 and $200 \mu \mathrm{S} / \mathrm{cm}$ (fig. 17A). Specific conductance was lower during stormflow than base flow at all 12 watersheds, indicating that dissolved constituents generally were diluted during stormflow conditions. Specific conductance typically was highest for Yellow River and Suwannee Creek, the two largest watersheds in the study area, with drainage areas of 162 and 47 square miles, respectively (table 1 ). Turbidity typically varied between 2 and $20 \mathrm{FNU}$ for base-flow samples and between 20 and 2,000 FNU for stormflow samples (fig. 17B). Turbidity values generally are about 1.5 orders of magnitude higher in stormflow, reflecting the transport of sediment during these conditions.

Nitrogen concentrations typically varied between 0.2 and 4 milligrams per liter as nitrogen $(\mathrm{mg} / \mathrm{L}$ as $\mathrm{N})$ for total nitrite plus nitrate $\left(\mathrm{NO}_{2}+\mathrm{NO}_{3}\right.$; fig. 17C), between 0.15 and $4 \mathrm{mg} / \mathrm{L}$ as $\mathrm{N}$ for total ammonia plus organic nitrogen (TKN; fig. $17 D$ ), and between 0.5 and $4 \mathrm{mg} / \mathrm{L}$ as $\mathrm{N}$ for total nitrogen (TN; fig. 17E). Differences between base flow and stormflow $\mathrm{NO}_{2}+\mathrm{NO}_{3}$ concentrations varied across the watersheds, with lower concentrations observed during stormflow at Yellow River, Big Haynes Creek, Wheeler Creek, and Suwanee Creek watersheds, higher concentrations observed during stormflow at Level Creek watershed, and similar ranges in concentrations observed at the other watersheds. Total ammonia plus organic nitrogen concentrations in stormflow samples were higher than concentrations in base-flow samples at all the watersheds, and TN concentrations in stormflow samples were higher than concentrations in base-flow samples at most of the watersheds. Stormflow sample concentrations were typically about twice as high as base-flow sample concentrations. Both Yellow River and No Business Creek watersheds have similar TN concentrations for base-flow and stormflow samples, and the increase in TN concentrations during stormflow observed for Suwannee Creek watershed was negligible.

Total phosphorus concentrations typically varied between 0.005 and $1 \mathrm{mg} / \mathrm{L}$ as phosphorus (P) (fig. 17F). Total phosphorus concentrations typically were greater than $0.1 \mathrm{mg} / \mathrm{L}$, which is the threshold at which TP concentrations are considered able to support nuisance levels of algal production in flowing waters (U.S. Environmental Protection Agency, 2000a). Stormflow TP concentrations were about an order of magnitude higher than during base flow, indicating that the majority of transport occurred during storm events. Dissolved phosphorus concentrations typically were less than $0.1 \mathrm{mg} / \mathrm{L}$ as $\mathrm{P}$ and exhibited no particular pattern of differences between base-flow and stormflow conditions (fig. 17G). A comparison of mean DP and TP concentrations (tables 1-1 to 1-12) indicates that about two-thirds to three-quarters of the phosphorus exists in solid form; therefore, it is not unexpected that TP concentrations are higher when discharge and suspended-sediment concentrations are higher. Richland Creek watershed had the highest mean stormflow TP concentration, $0.267 \mathrm{mg} / \mathrm{L}$ as $\mathrm{P}$, which may be the result of high runoffs (fig. 14A) and water yields (fig. 14B) associated with the watershed having the highest basin slope of the 12 watersheds, (fig. 5; table 3). No Business Creek had the lowest mean stormflow TP concentration of $0.066 \mathrm{mg} / \mathrm{L}$ as $\mathrm{P}$.

Total organic carbon (TOC) typically varied between 0.5 and $4 \mathrm{mg} / \mathrm{L}$ as carbon in base-flow samples and between 2 and $20 \mathrm{mg} / \mathrm{L}$ as $\mathrm{C}$ in stormflow samples (fig. 17H). Stormflow TOC concentrations are about half an order of magnitude higher than during base flow, but comparisons varied by watershed. Stormflow TOC concentrations were fairly similar among all 12 watersheds, whereas individual watersheds had more distinct base-flow concentrations.

Total lead $(\mathrm{Pb})$ concentrations typically varied between 0.1 and $10 \mu \mathrm{g} / \mathrm{L}$ in base-flow samples and between 0.5 and $100 \mu \mathrm{g} / \mathrm{L}$ in stormflow samples (fig. 17I). Base-flow $\mathrm{Pb}$ concentrations had a large range at 6 of the 12 watersheds, with about a 1.5 order of magnitude range between the 25 th and 75th percentiles of concentrations. Stormflow $\mathrm{Pb}$ concentrations were about a half an order of magnitude higher than base-flow concentrations.

Total zinc ( $\mathrm{Zn}$ ) concentrations typically varied between 2 and $500 \mu \mathrm{g} / \mathrm{L}$ (fig. 17J). Stormflow Zn concentrations were about one order of magnitude higher than base-flow concentrations, but comparisons varied by watershed. Richland Creek and Crooked Creek watersheds exhibited the largest order of magnitude increases between base-flow and stormflow Zn concentrations. Alcovy River, Richland Creek, Crooked Creek, and North Fork Peachtree Creek watersheds had the highest stormflow $\mathrm{Zn}$ and $\mathrm{Pb}$ concentrations. These high concentrations may be related to the high basin slope at Richland Creek (fig. 5; table 3) and the high percentage of impervious areas for Crooked Creek and North Fork Peachtree Creek (fig. 9; table 3).

Total dissolved solids (TDS) concentrations represent the amount of inorganic and organic constituents that are dissolved in water; concentrations typically varied between 20 and $200 \mathrm{mg} / \mathrm{L}$ (fig. 17K). The U.S. Environmental Protection Agency has established TDS as a secondary drinking water standard with a maximum contaminant level of $500 \mathrm{mg} / \mathrm{L}$, because high concentrations of TDS can be an indicator of elevated levels of other pollutants (U.S. Environmental Protection Agency, 2011). Five of the watersheds, Yellow River, Level Creek, Suwanee Creek, Crooked Creek, and North Fork Peachtree Creek, exhibited dilution in TDS concentrations during storm events. Four of these watersheds, Yellow River, Suwanee Creek, Crooked Creek, and North Fork Peachtree Creek, have the four highest percentages of impervious area (fig. 9; table 3). Yellow River watershed had the highest mean TDS concentrations of $95 \mathrm{mg} / \mathrm{L}$ (table 1-1) of the 12 watersheds. Richland Creek watershed had higher stormflow TDS and also has the highest basin slope of any of 

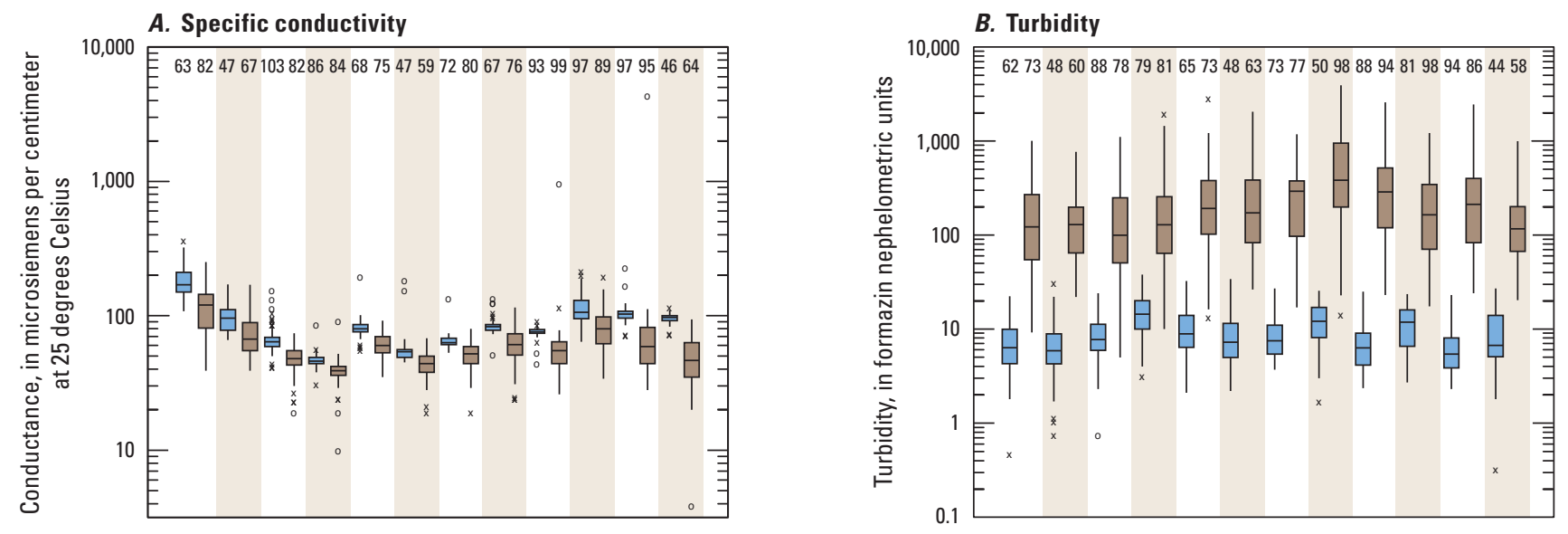

C. Total nitrite plus nitrate
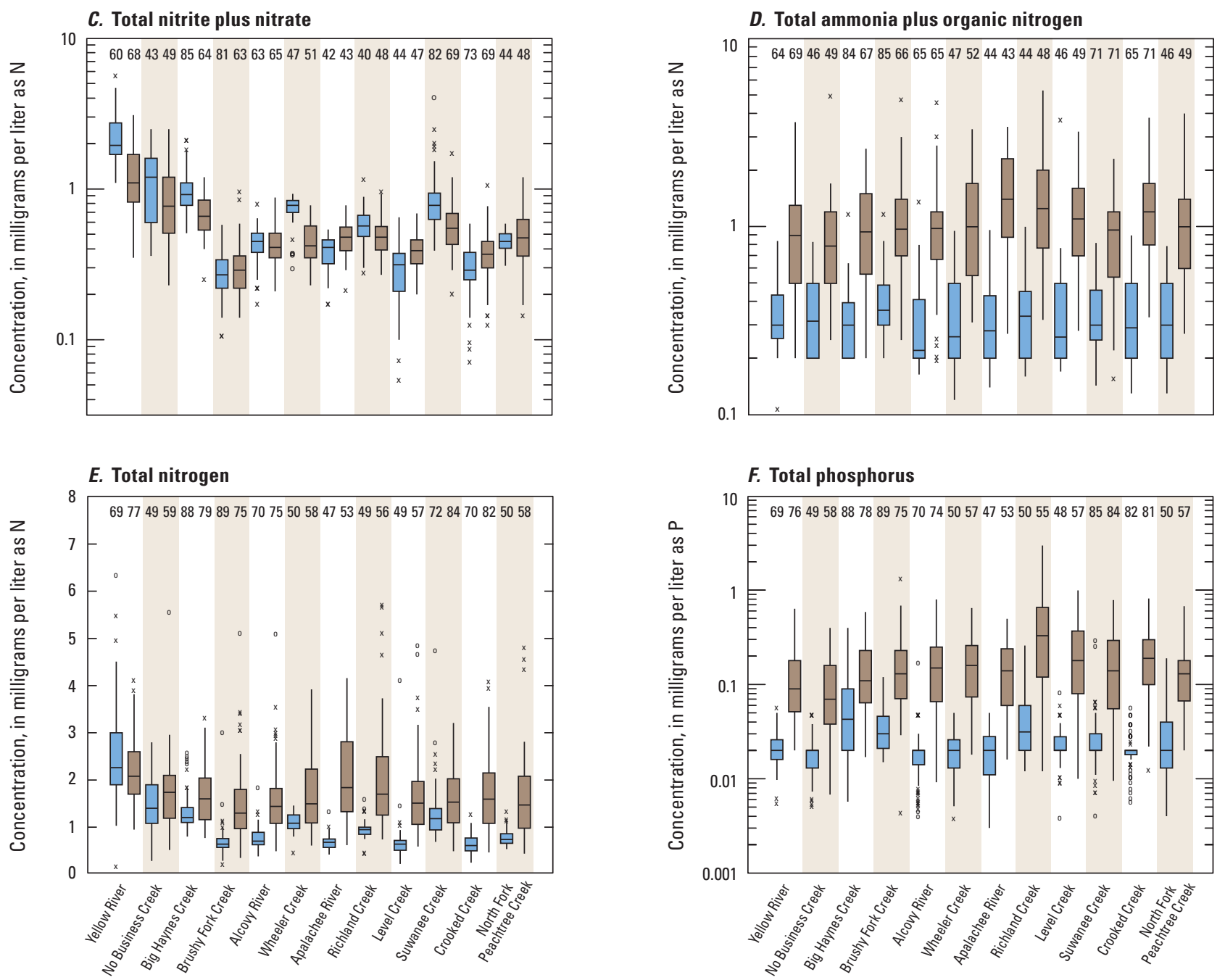

Figure 17. Boxplots of concentrations for $A$, specific conductance, $B$, turbidity, $C$, total nitrite plus nitrate, $D$, total ammonia plus organic nitrogen, $E$, total nitrogen, $F$, total phosphorus, $G$, dissolved phosphorus, $H$, total organic carbon, $I$, total lead, J, total zinc, $K$, total dissolved solids, $L$, total suspended solids, and, $M$, suspended sediment at 12 monitored watersheds in Gwinnett County, Georgia. Data collection period ranges from 1996 to 2009. 

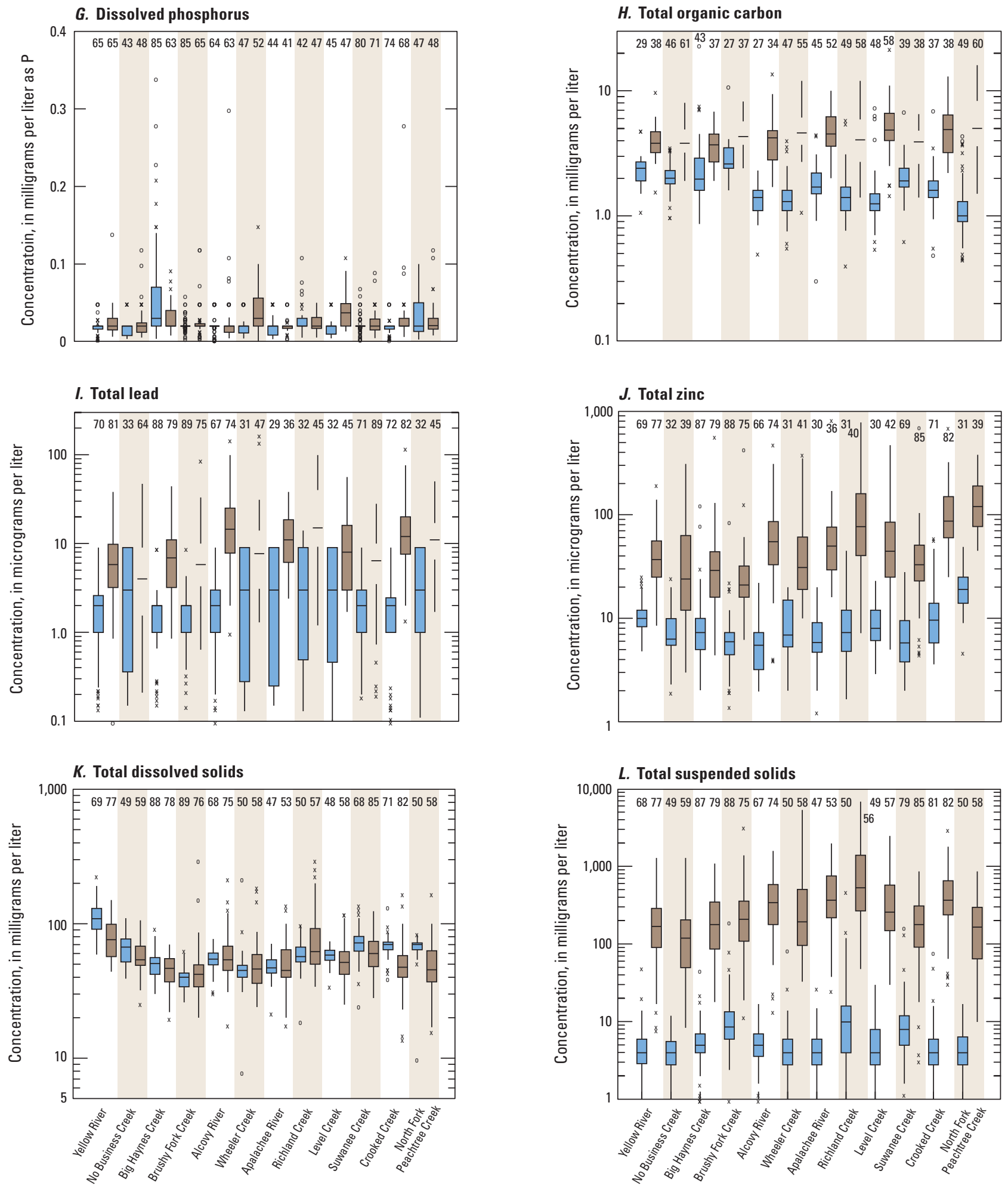

Figure 17. (Continued) Boxplots of concentrations for $A$, specific conductance, $B$, turbidity, $C$, total nitrite plus nitrate, $D$, total ammonia plus organic nitrogen, $E$, total nitrogen, $F$, total phosphorus, $G$, dissolved phosphorus, $H$, total organic carbon, I, total lead, $J$, total zinc, $K$, total dissolved solids, $L$, total suspended solids, and, $M$, suspended sediment at 12 monitored watersheds in Gwinnett County, Georgia. Data collection period ranges from 1996 to 2009. 

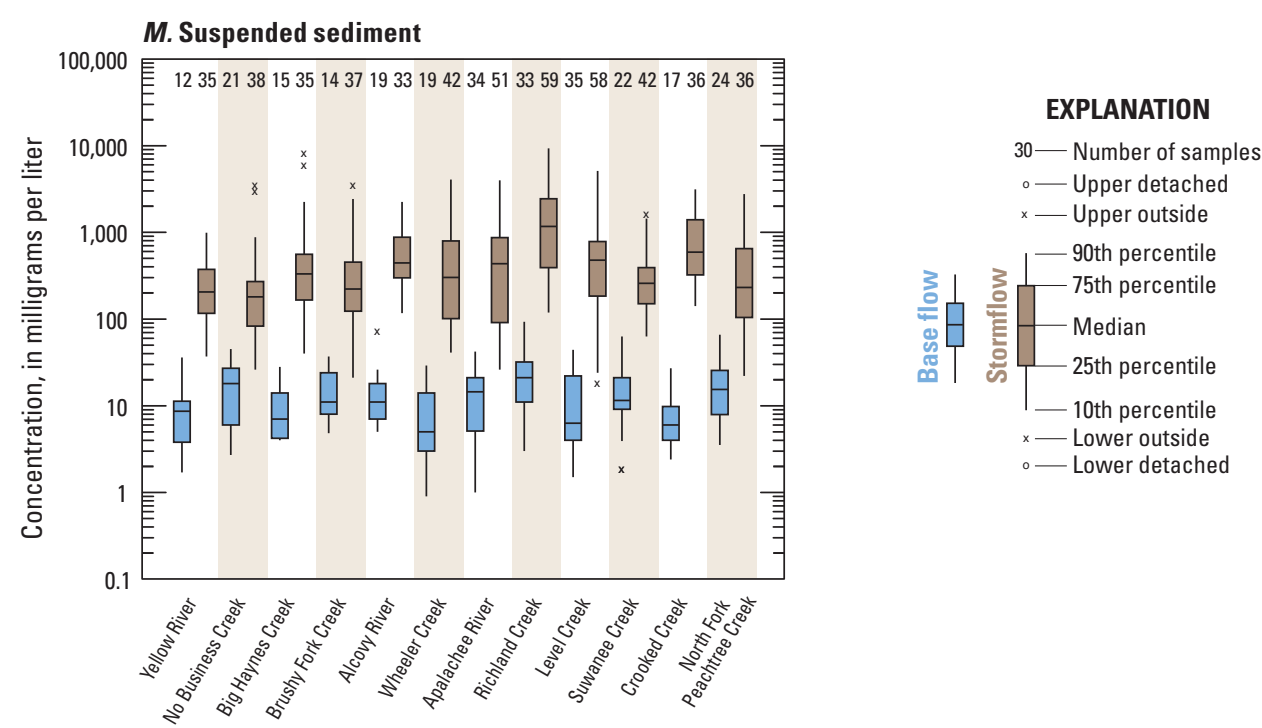

Figure 17. (Continued) Boxplots of concentrations for $A$, specific conductance, $B$, turbidity, $C$, total nitrite plus nitrate, $D$, total ammonia plus organic nitrogen, $E$, total nitrogen, $F$, total phosphorus, $G$, dissolved phosphorus, $H$, total organic carbon, $I$, total lead, $J$, total zinc, $K$, total dissolved solids, $L$, total suspended solids, and, $M$, suspended sediment at 12 monitored watersheds in Gwinnett County, Georgia. Data collection period ranges from 1996 to 2009.

One of the leading causes of stream impairment in Georgia is sediment-associated constituents (U.S. Environmental Protection Agency, 2010). Annual yield of TSS is the primary performance criterion for suspended sediment in Gwinnett County's Watershed Protection Plan (Gwinnett County Department of Public Utilities, 2000). Sources of in-stream sediment can be highly variable. Sediment transport can occur from natural processes such as resuspension of streambed sediment or from land disturbance from development and urbanization. Land disturbances and extreme hydrologic events can cause streambanks to collapse and fail, adding to the alluvial sediment being transported. Runoff from impervious surfaces also contributes to the fluvial sediments and contaminant attributed in the annual sediment yields. Certain contaminants, such as trace elements and pesticides, sometimes preferentially partition onto sediment; thus, their distribution throughout the watersheds is controlled primarily by sediment transport (Hardy and others, 2005). 
the 12 watersheds (fig. 5; table 3 ). For the remaining seven watersheds, base-flow and stormflow TDS concentrations varied in similar, overlapping ranges. Variations in TDS are difficult to interpret because TDS comprises all the dissolved constituents, each with their own particular relations, into a single measure.

Total suspended solids (TSS) and suspended-sediment concentrations (SSC) typically varied between 1 and 2,000 mg/L (fig. 17L and 17M). Total suspended solids and SSC concentrations are similar, with the same pattern of relative difference between watersheds observed for both constituents that is especially apparent in the stormflow concentrations. Suspended-sediment concentrations typically were slightly higher than TSS concentrations during both base-flow and stormflow conditions. Stormflow TSS and SSC concentrations are about two orders of magnitude higher than baseflow concentrations, emphasizing the relation between discharge and sediment mobilization and transport. Richland Creek watershed, which has the highest basin slope of any of the 12 watersheds (fig. 5; table 3), had the highest mean TSS concentration, $592 \mathrm{mg} / \mathrm{L}$ (appendix table 1-8). The two orders of magnitude increase of TSS concentrations from base flow to stormflow compared to the one order of magnitude increase for TP concentrations suggests that the suspended sediment transported during storm events has a disproportionately smaller ratio of TP compared to base-flow conditions. Total suspended solids concentrations are about three orders of magnitude greater than TP in storm event samples, indicating that TP is only a small portion of TSS.

In a previous analysis of the Gwinnett County LTTM program watersheds for six watersheds for the period 1998-2003, (Landers and others, 2007), concentrations (and loads) of TSS typically were less than concentrations (and loads) of SSC. The comparison of TSS to SSC was reevaluated using data from all 12 watersheds for the period 2005-09 (fig. 18; Landers, 2013). Measured TSS concentrations continue to be less than SSC concentrations. This difference is more pronounced for samples in which the sediment contains more than 25 percent sand (the coarser portion of the sediment).

\section{Water-Quality Seasonality and Long- Term Trends}

Both seasonal patterns and long-term trends for five representative water-quality constituents-TN, TP, TDS, TSS, and $\mathrm{Zn}$ - were examined in base-flow and stormflow samples. These patterns and trends can be the result of natural variability, such as seasonal biogeochemical processes, climatic variations, and human influences. The effects of variations in discharge, for which a strong relation is observed for most of the water-quality constituents in this study, have been removed by using flow-adjusted residual concentrations to model-fitted logarithmic concentration-discharge relations.

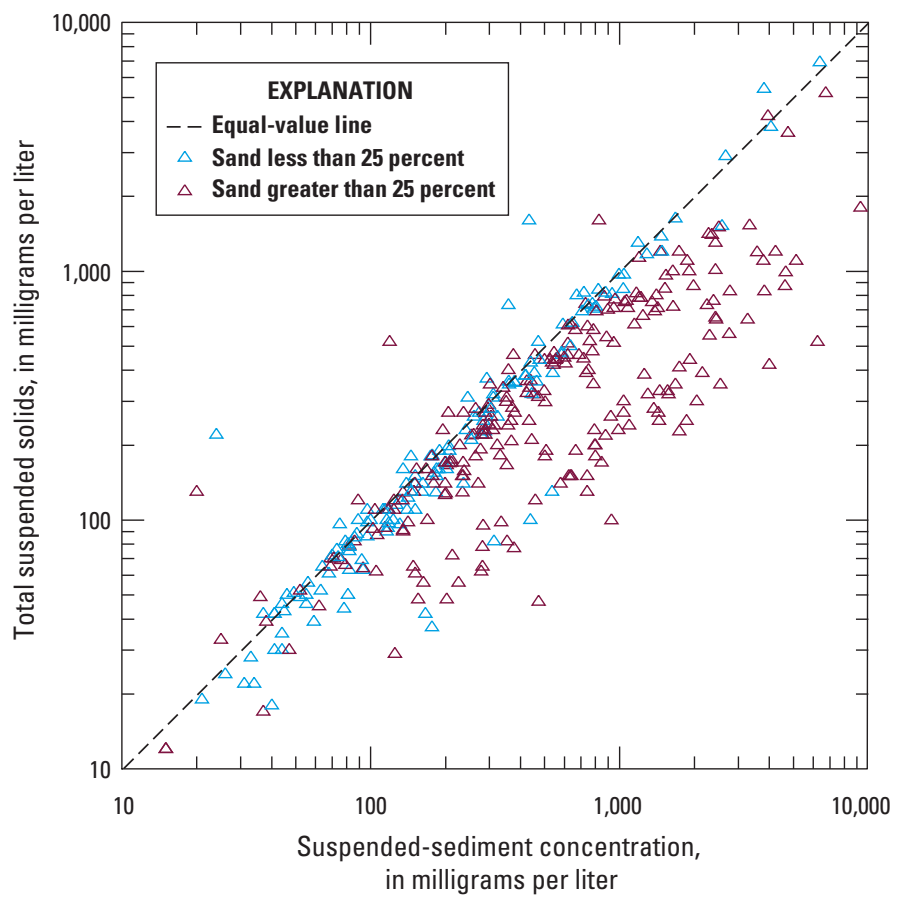

Figure 18. Concentrations of total suspended solids and suspended-sediment concentrations for 380 storm samples collected in watersheds in Gwinnett County, Georgia (modified from Landers, 2013).

\section{Seasonality in Water Quality}

An analysis of seasonal patterns in base-flow and stormflow samples was performed for five representative water-quality constituents - TN, TP, TDS, TSS, and Zn-on flow-adjusted residual concentrations. Base-flow residuals typically did not exhibit any significant seasonal variations at any of the 12 watersheds. Seasonal terms were significant in all the stormflow concentration regression models (for all five constituents and all 12 watershed combinations). Seasonality is considered significant when the seasonal sine and cosine explanatory variables in the regression equations used for load estimation are significant for $p$-values less than or equal to 0.1 .

Total nitrogen and TP seasonal patterns were fairly similar at all 12 watersheds, with the highest concentrations typically between May through September and the lowest concentrations between November and January (figs. 19-20). The only obvious exception to this was for the Suwanee Creek watershed, which had high TN and TP concentrations in January that were similar to summer peak concentrations. The magnitude of the seasonal variations ranged from about 0.1 to 0.3 logarithmic unit for $\mathrm{TN}$ and about 0.2 to 0.4 logarithmic unit for TP. 
02207120 Yellow River

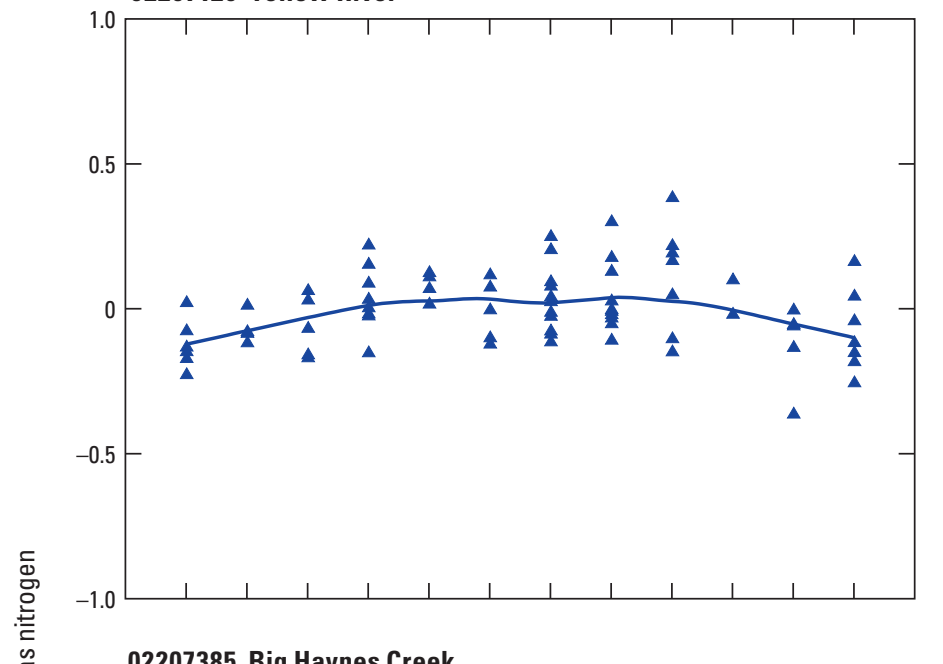

这
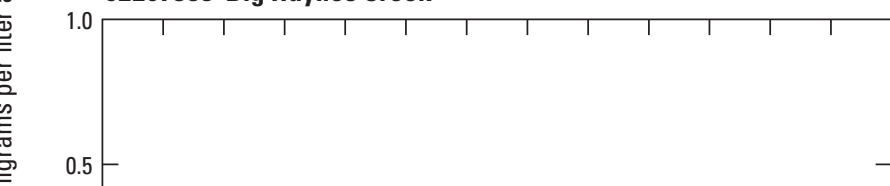

要

$-1.0$

02208150 Alcovy River

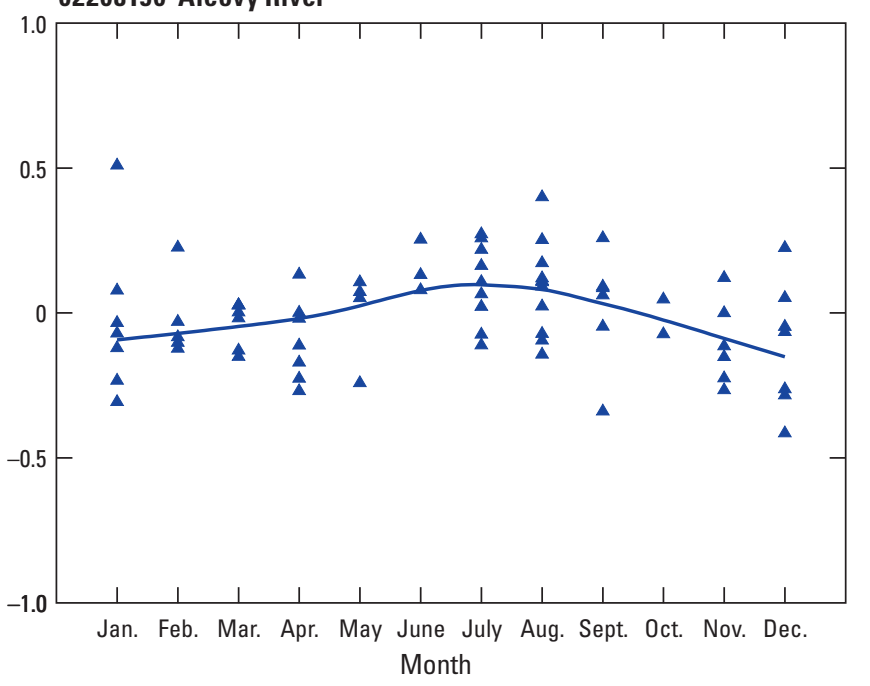

02207185 No Business Creek

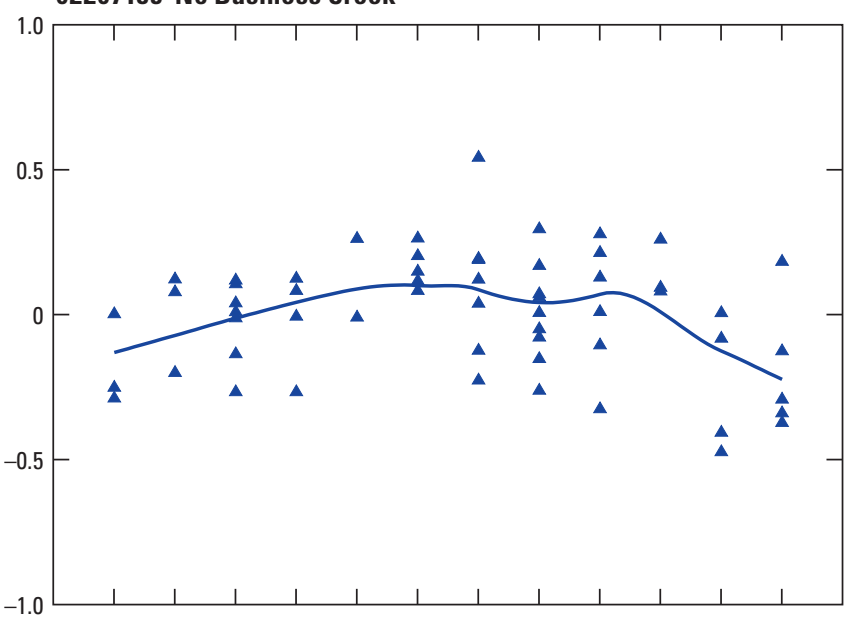

02207400 Brushy Fork Creek

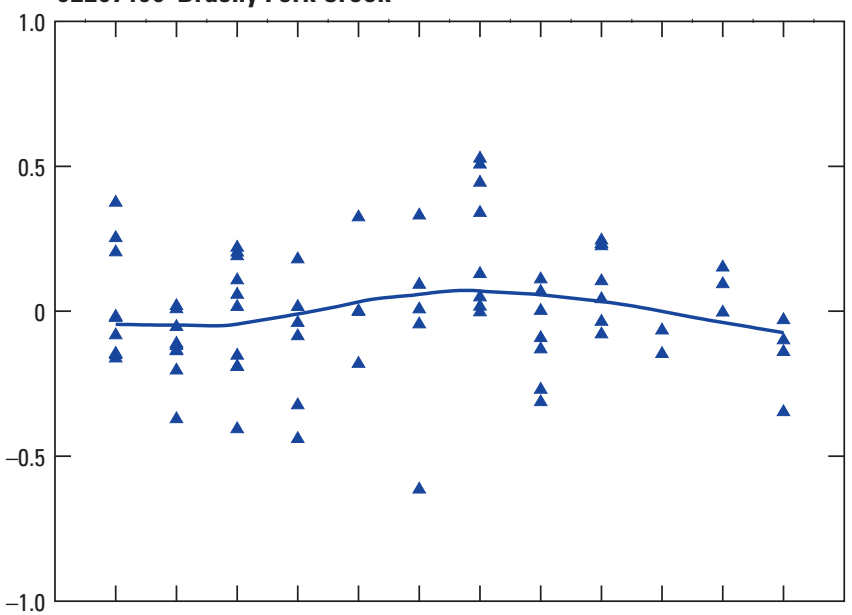

02217274 Wheeler Creek

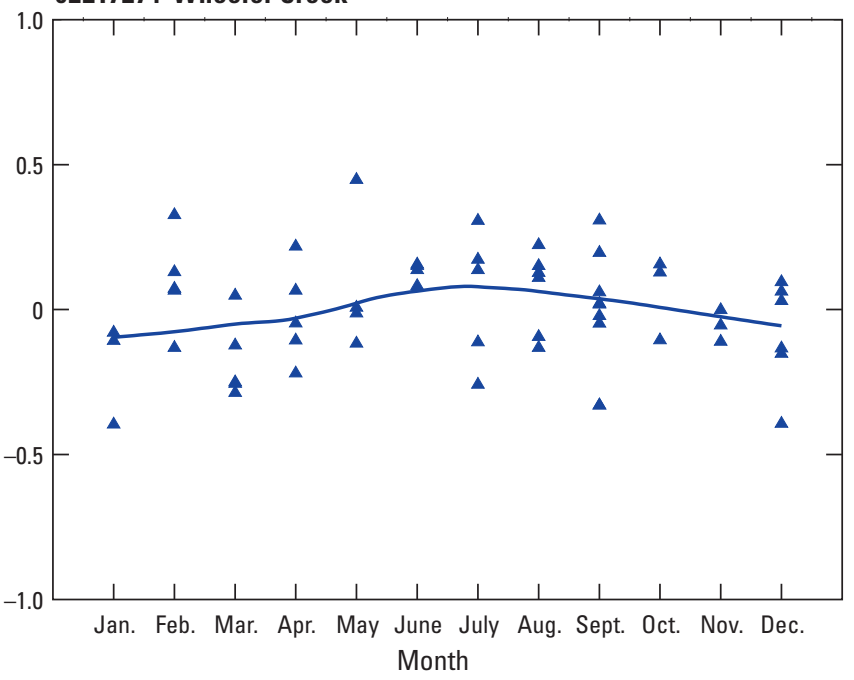

Figure 19. Seasonal patterns in stormflow total nitrogen flow-adjusted residual concentrations for the 12 monitored watersheds in Gwinnett County, Georgia. A line representing a locally weighted regression and smoothing scatterplots (LOWESS) curve is shown to graphically identify the seasonal pattern. 
02218565 Apalachee River

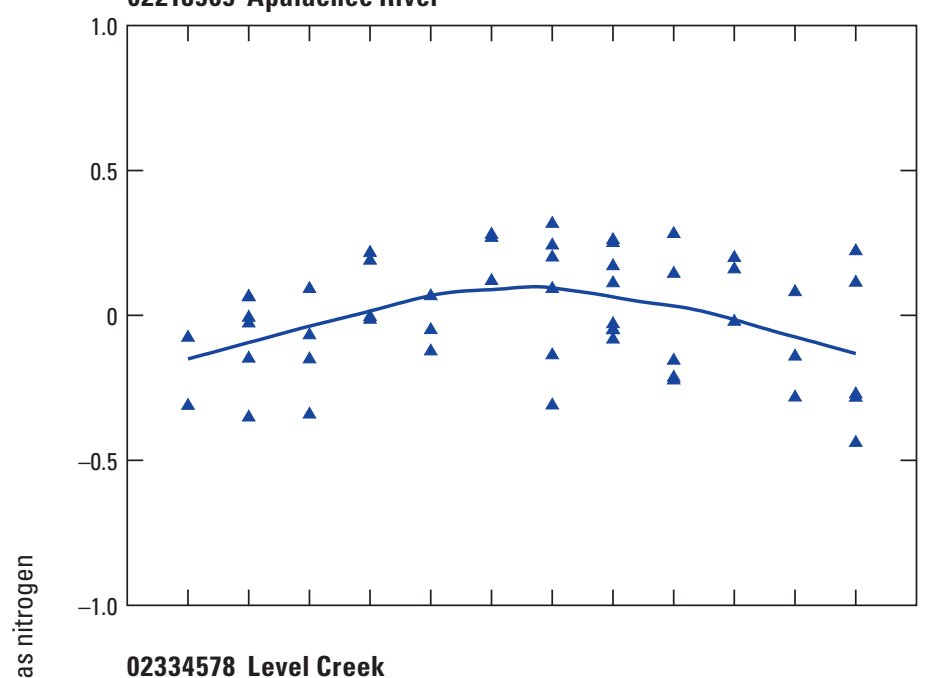

02334578 Level Creek

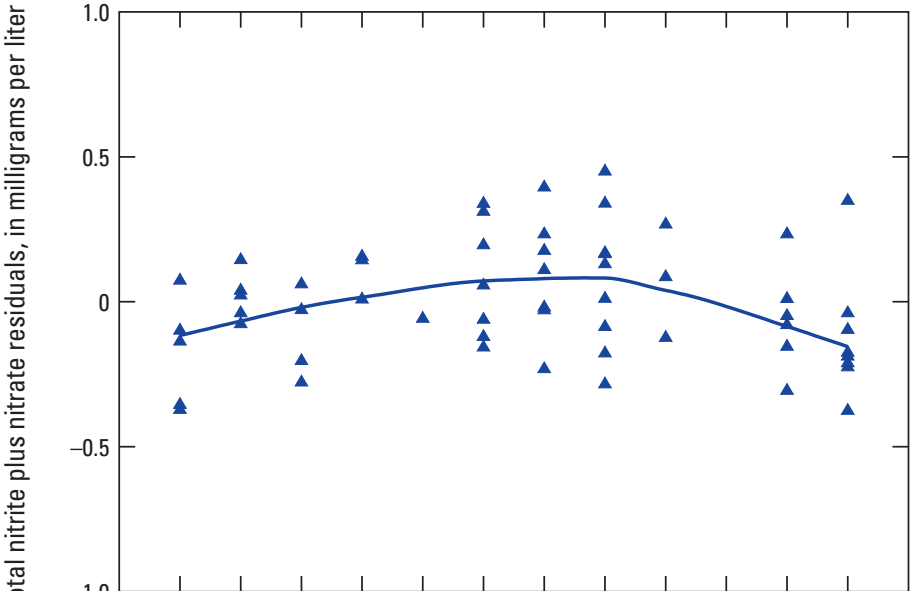

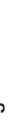

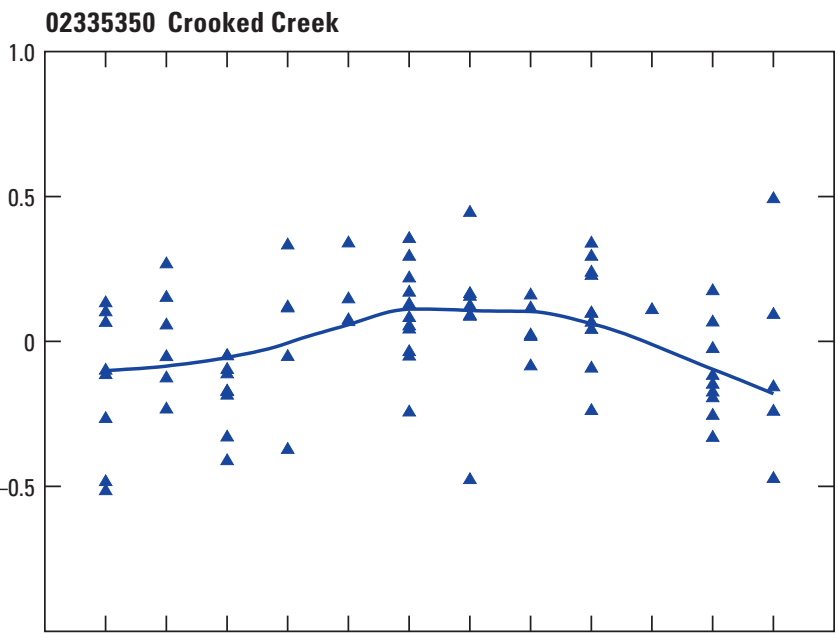

Jan. Feb. Mar. Apr. May June July Aug. Sept. Oct. Nov. Dec.

Month
02334480 Richland Creek

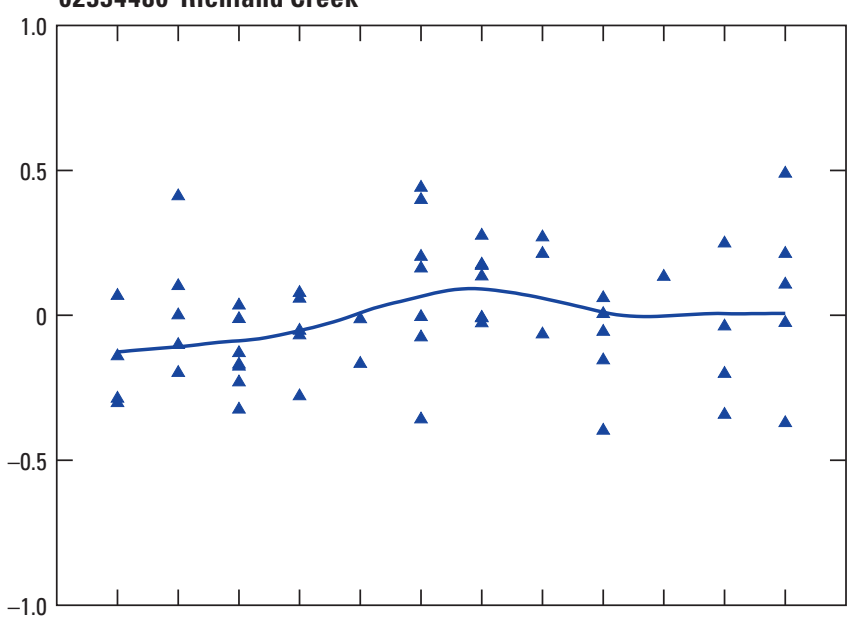

02334885 Suwanee Creek

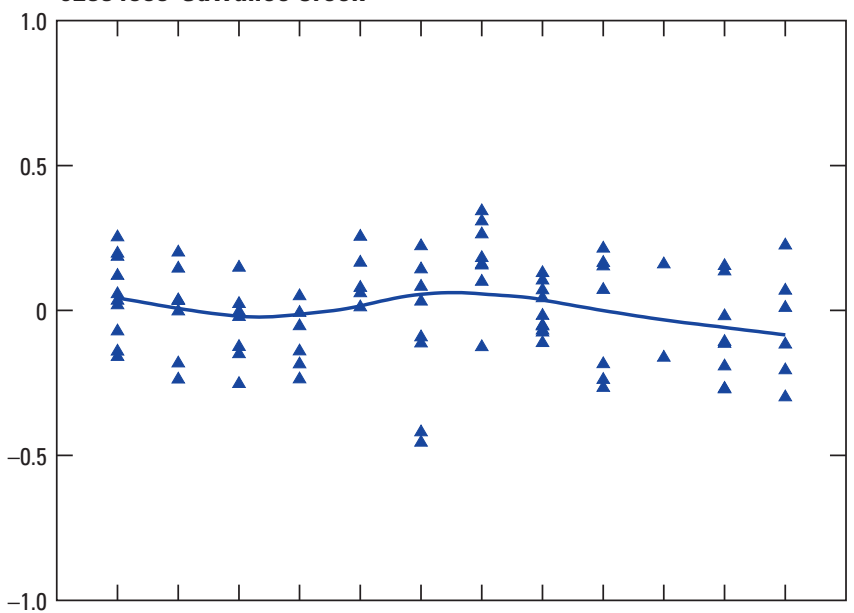

02336030 North Fork Peachtree Creek

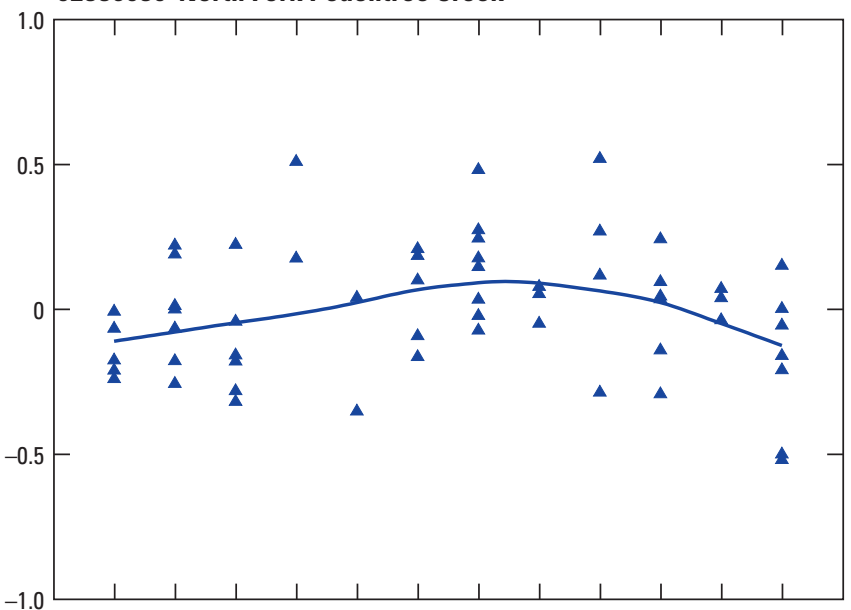

Jan. Feb. Mar. Apr. May June July Aug. Sept. Oct. Nov. Dec. Month

Figure 19. (Continued) Seasonal patterns in stormflow total nitrogen flow-adjusted residual concentrations for the 12 monitored watersheds in Gwinnett County, Georgia. A line representing a locally weighted regression and smoothing scatterplots (LOWESS) curve is shown to graphically identify the seasonal pattern. 

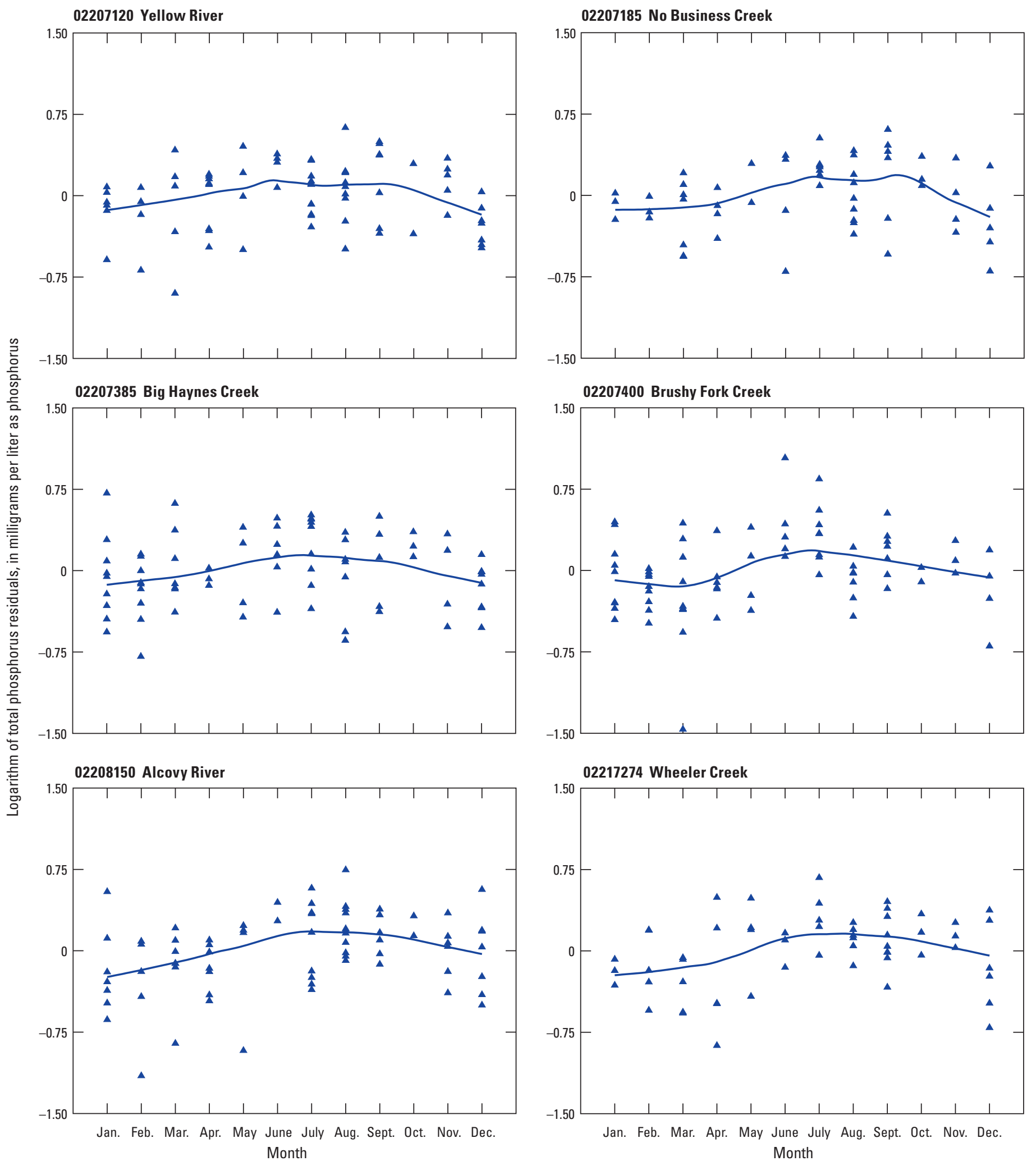

Figure 20. Seasonal patterns in stormflow total phosphorus flow-adjusted residual concentrations for the 12 monitored watersheds in Gwinnett County, Georgia. A line representing a locally weighted regression and smoothing scatterplots (LOWESS) curve is shown to graphically identify the seasonal pattern. 
02218565 Apalachee River

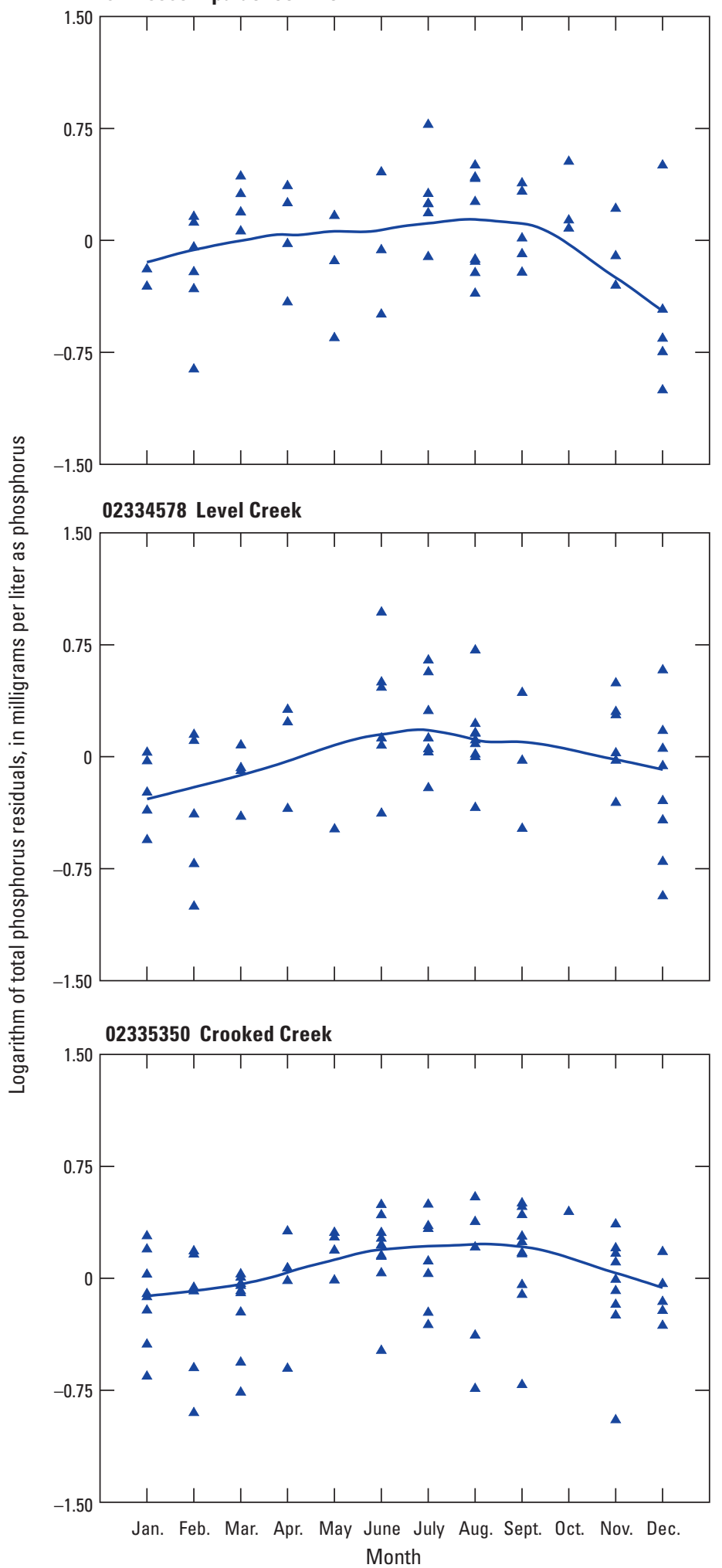

02334480 Richland Creek

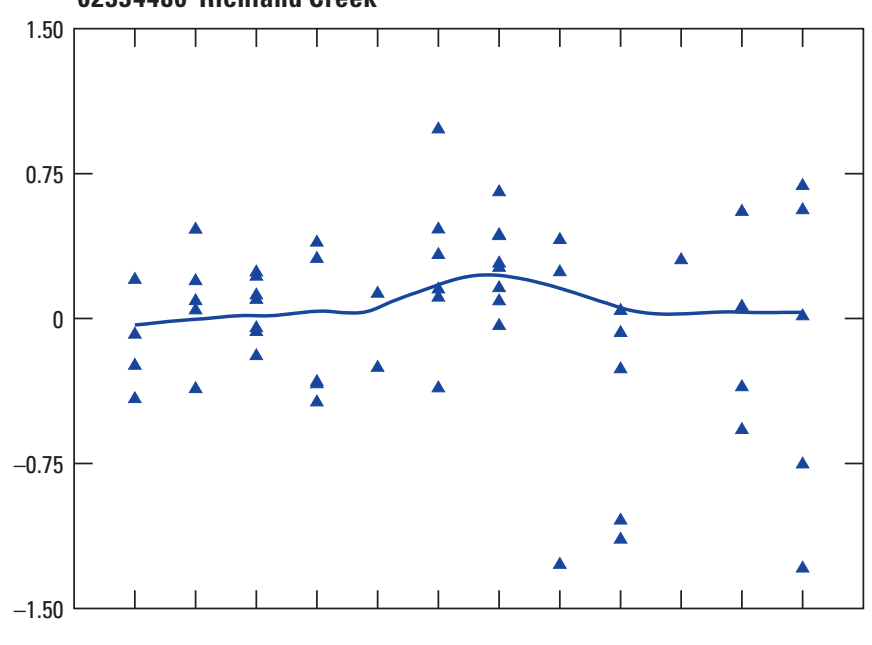

02334885 Suwanee Creek
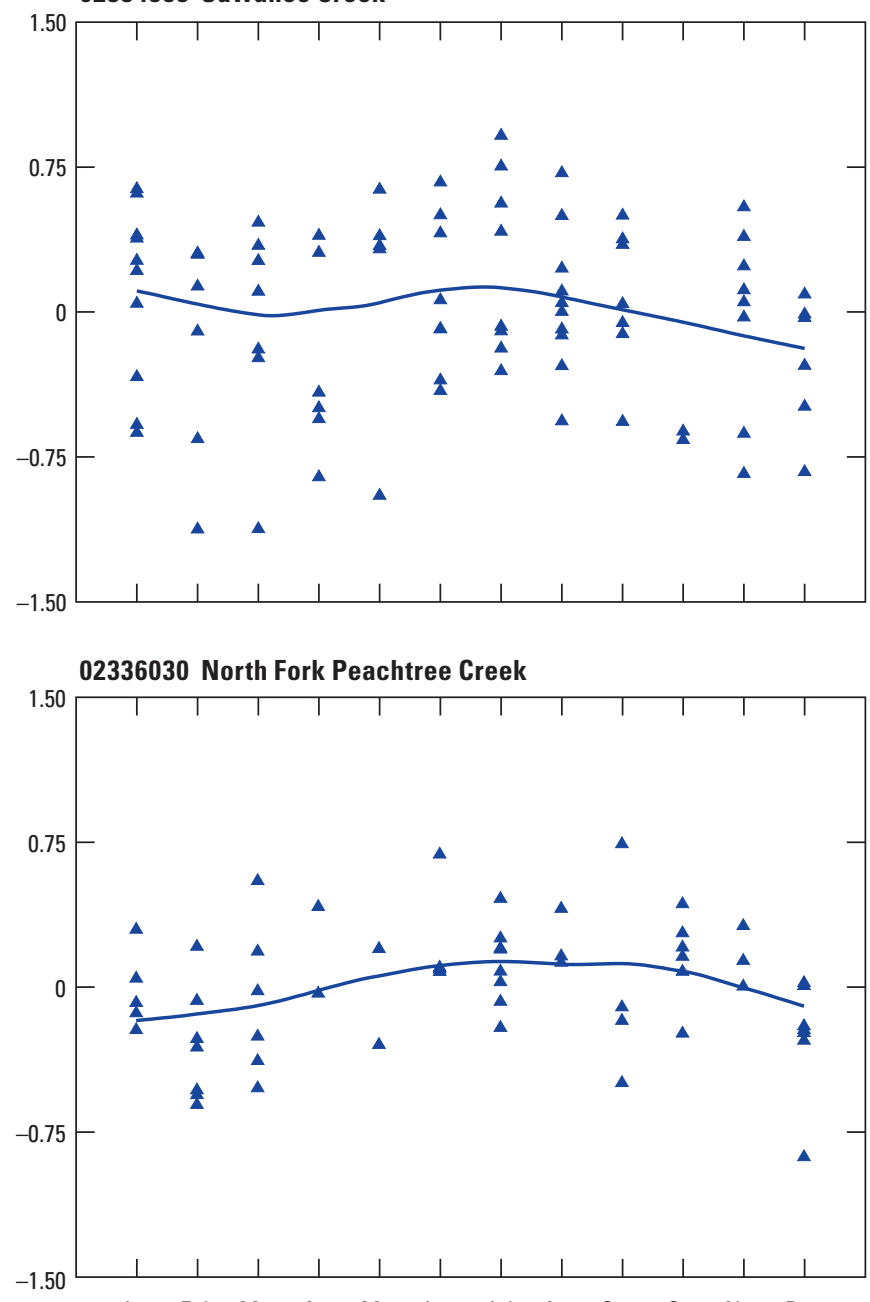

Jan. Feb. Mar. Apr. May June July Aug. Sept. Oct. Nov. Dec Month

Figure 20. (Continued) Seasonal patterns in stormflow total phosphorus flow-adjusted residual concentrations for the 12 monitored watersheds in Gwinnett County, Georgia. A line representing a locally weighted regression and smoothing scatterplots (LOWESS) curve is shown to graphically identify the seasonal pattern. 


\section{Watershed Characteristics and Water-Quality Trends and Loads in 12 Watersheds in Gwinnett County, Georgia}

Seasonal patterns in TDS were small, typically less than 0.1 logarithmic unit, but getting as high as 0.2 logarithmic unit (fig. 21). For the few watersheds that had large seasonal variations (Apalachee River, Richland Creek, and North Fork Peachtree Creek), peak concentrations were observed in July and August and the lowest TDS concentrations were in December.

Stormflow TSS flow-adjusted residual concentrations are plotted by month for each watershed (fig. 22). LOWESS curves indicate that the timing of the seasonal patterns in TSS concentrations were fairly similar at all 12 watersheds, typically highest in June through September and lowest in December through March. These seasonal patterns may be related to seasonal variations in rainfall intensities; winter rainstorms are characterized by typically low-intensity frontal systems, whereas spring and summer rainstorms are characterized by intense convective thunderstorms. Intense rainfall can result in greater storm-related erosion due to higher peak streamflows and the higher occurrence of overland flow. Increased summer TSS concentrations may also be related to seasonal construction, which can result in increased wash-off of sediments. On the basis of the LOWESS curves, seasonal TSS flow-adjusted residual concentrations ranged from about 0.3 to about 0.6 logarithmic unit in the 12 watersheds. Yellow River, No Business Creek, Wheeler Creek, and Suwanee Creek had the largest seasonal variations. Yellow River and Suwanee Creek watersheds are the two largest watersheds in the study, with drainage areas of 162 and 47 square miles, respectively, and Wheeler Creek is the smallest watershed in the study with a drainage area of 1.31 square miles (table 1).

Seasonal patterns in total $\mathrm{Zn}$ concentrations were fairly similar at all 12 watersheds, with the highest concentrations typically between June through September and the lowest concentrations between November and February (fig. 23). The magnitude of the seasonal variations ranged from about 0.2 to 0.5 logarithmic unit. 
02207120 Yellow River

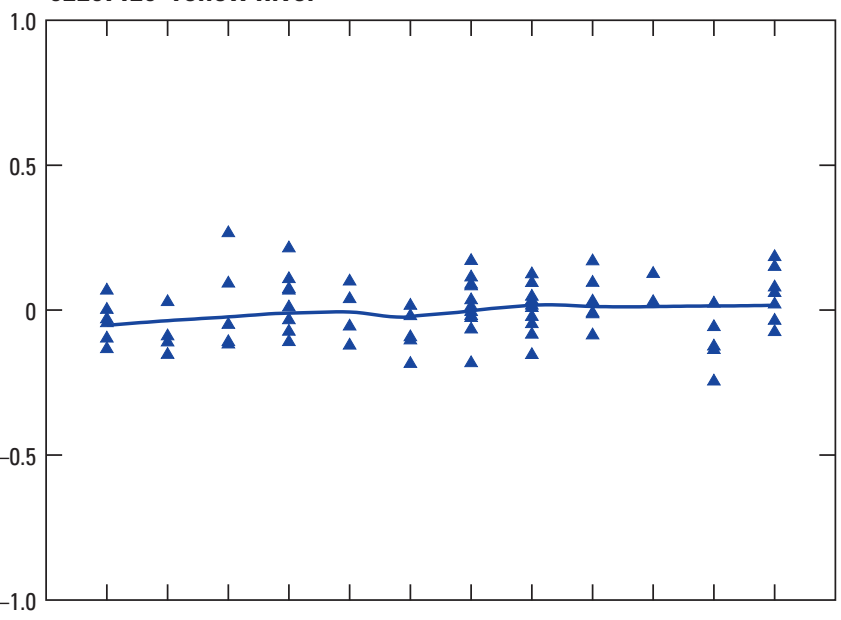

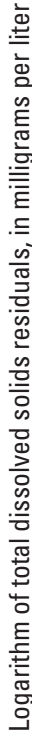

02207385 Big Haynes Creek
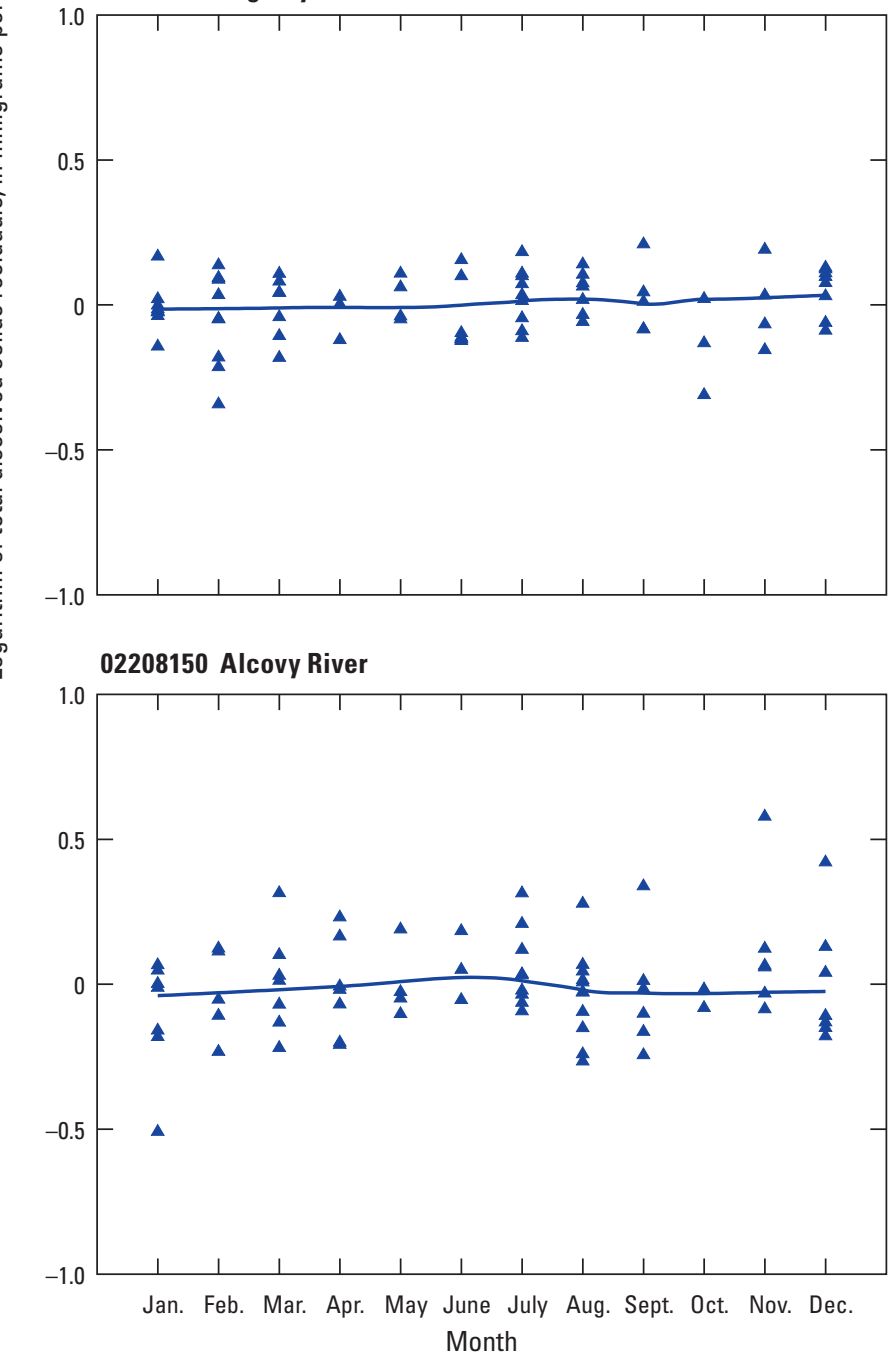

02207185 No Business Creek

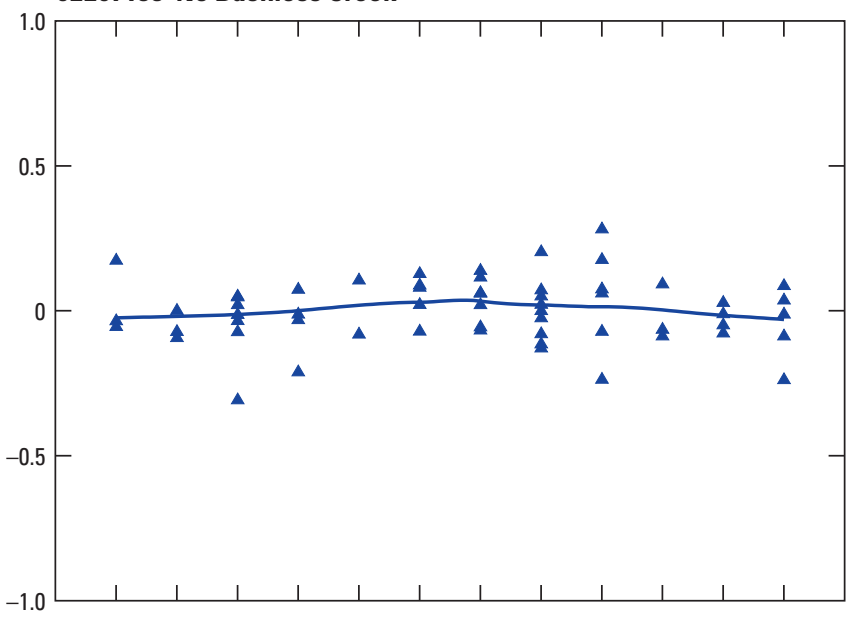

02207400 Brushy Fork Creek

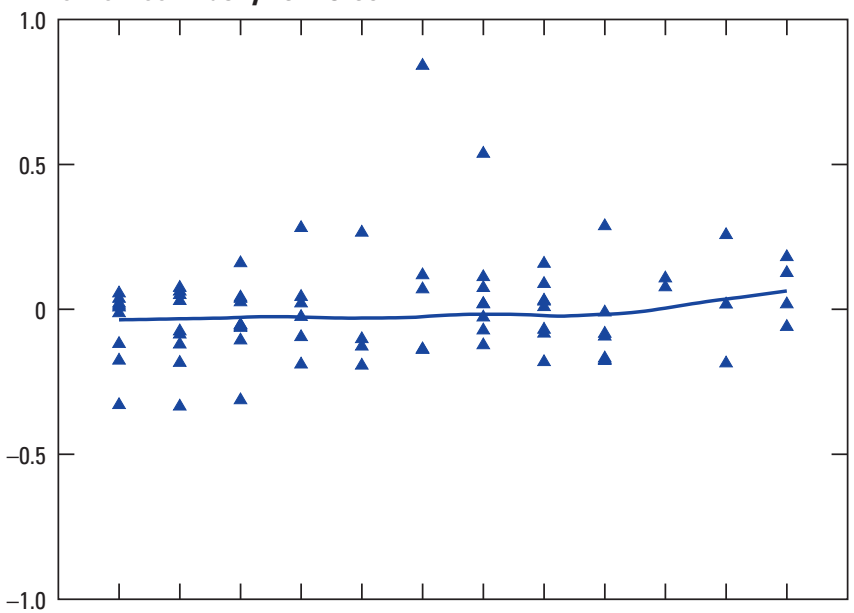

02217274 Wheeler Creek

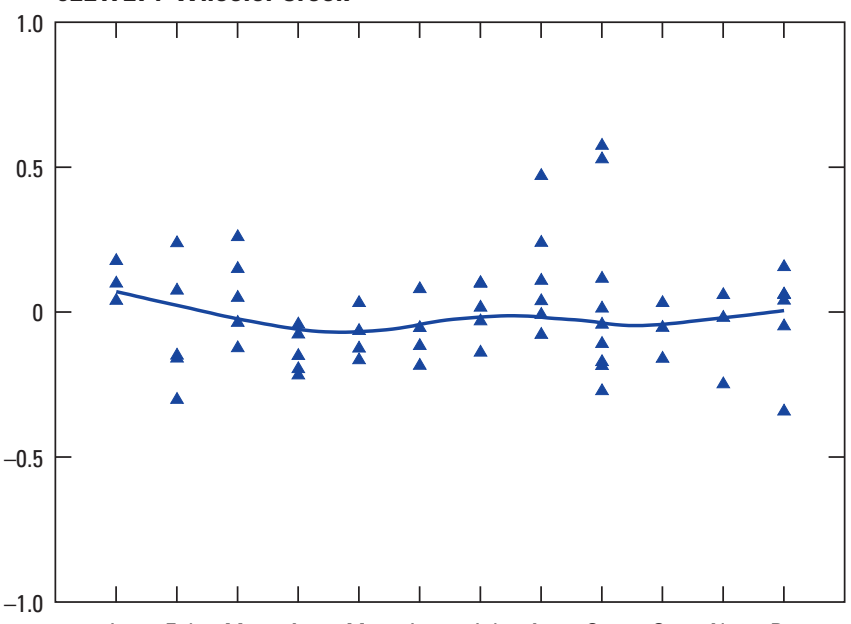

Jan. Feb. Mar. Apr. May June July Aug. Sept. Oct. Nov. Dec. Month

Figure 21. Seasonal patterns in stormflow total dissolved solids flow-adjusted residual concentrations for the 12 monitored watersheds in Gwinnett County, Georgia. A line representing a locally weighted regression and smoothing scatterplots (LOWESS) curve is shown to graphically identify the seasonal pattern. 

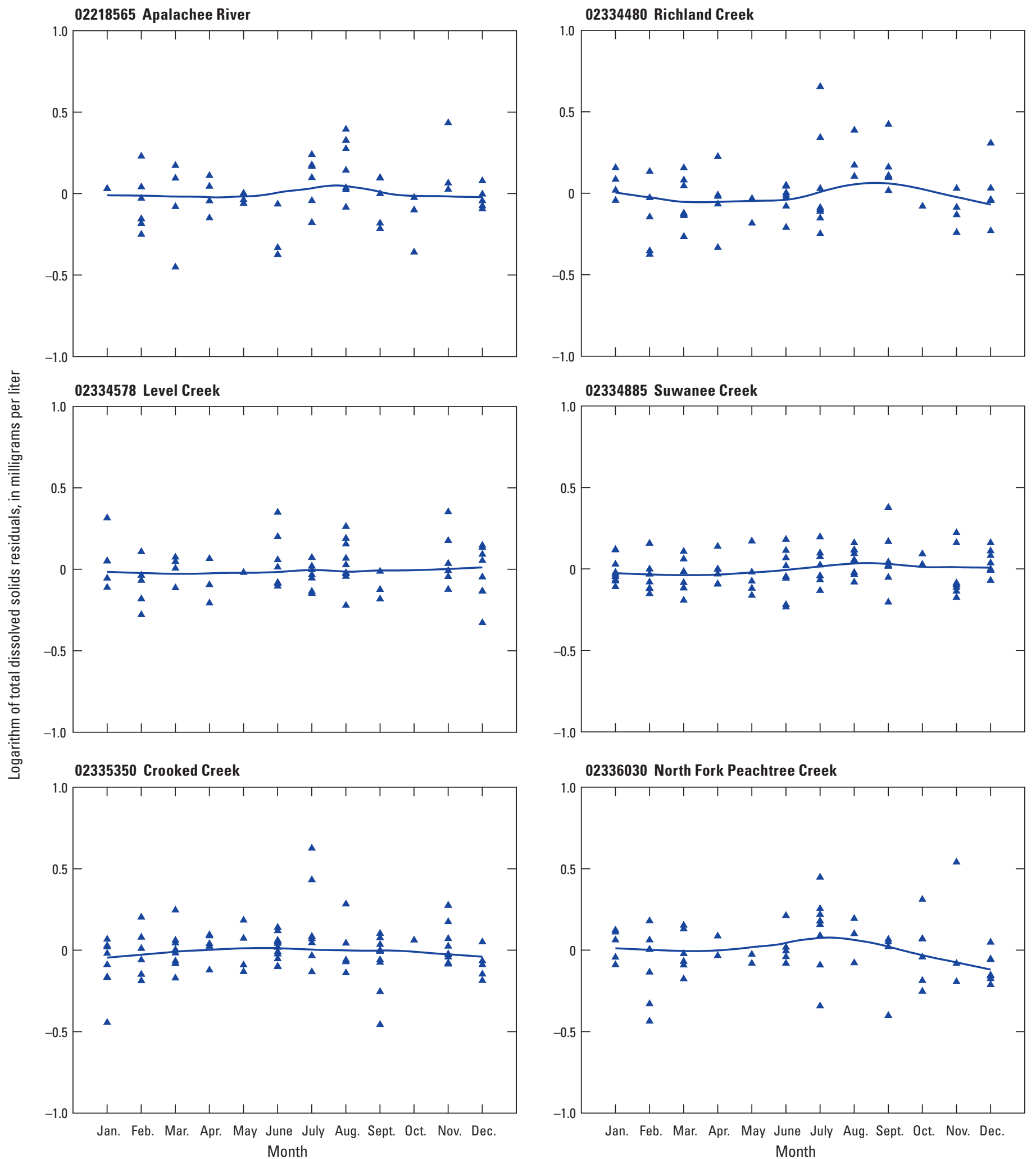

Jan. Feb. Mar. Apr. May June July Aug. Sept. Oct. Nov. Dec. Month

Figure 21. (Continued) Seasonal patterns in stormflow total dissolved solids flow-adjusted residual concentrations for the 12 monitored watersheds in Gwinnett County, Georgia. A line representing a locally weighted regression and smoothing scatterplots (LOWESS) curve is shown to graphically identify the seasonal pattern. 
02207120 Yellow River

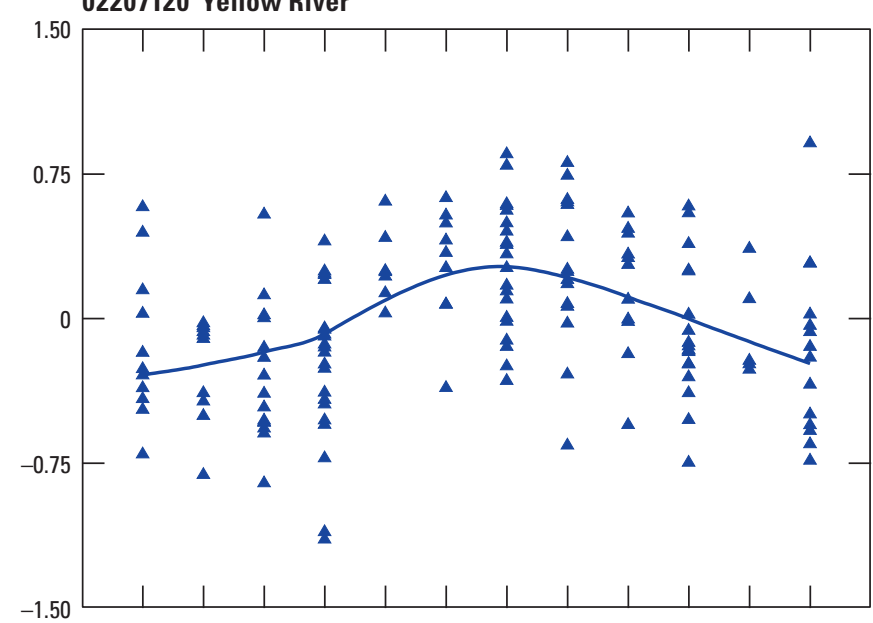

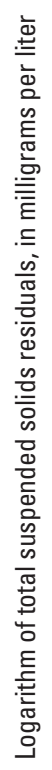

02207385 Big Haynes Creek

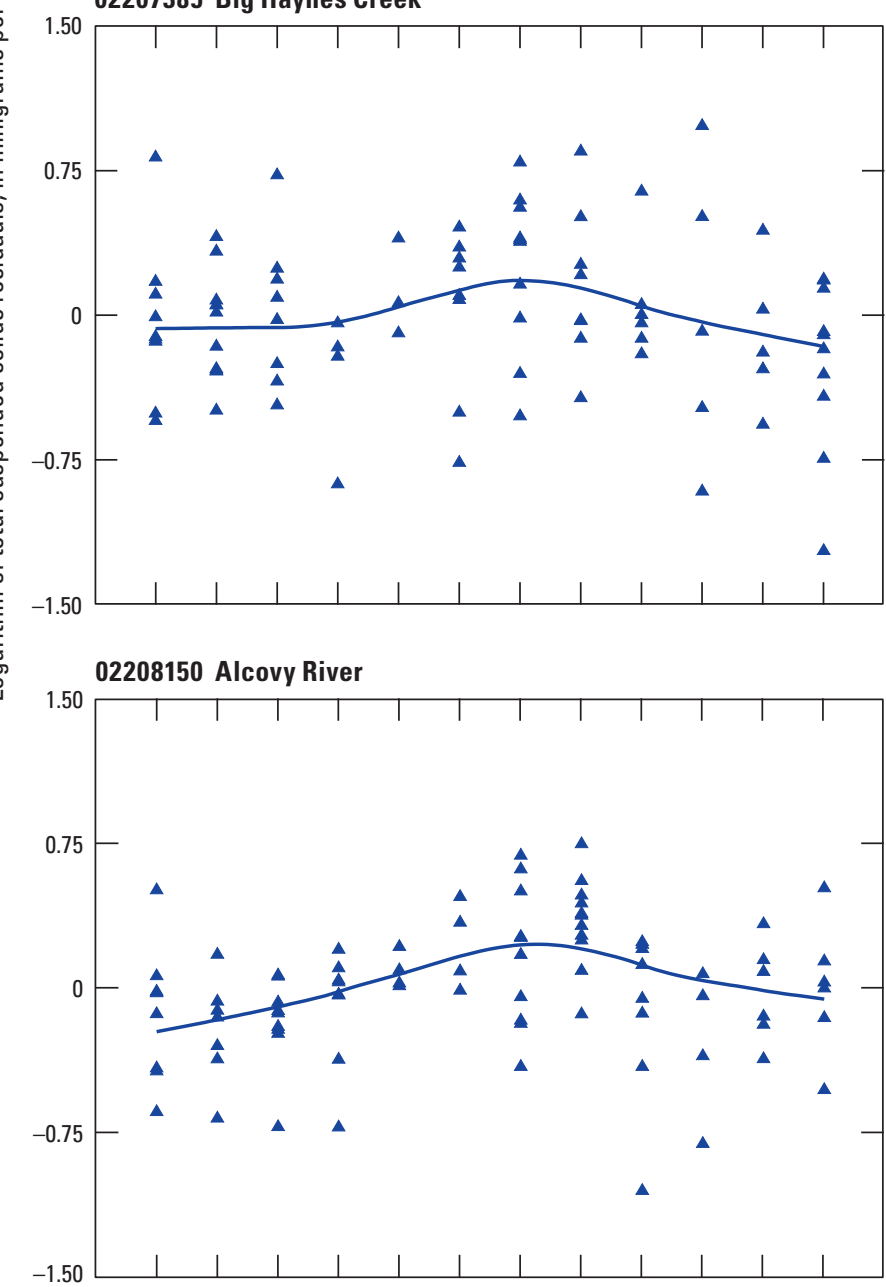

Jan. Feb. Mar. Apr. May June July Aug. Sept. Oct. Nov. Dec.

Month
02207185 No Business Creek

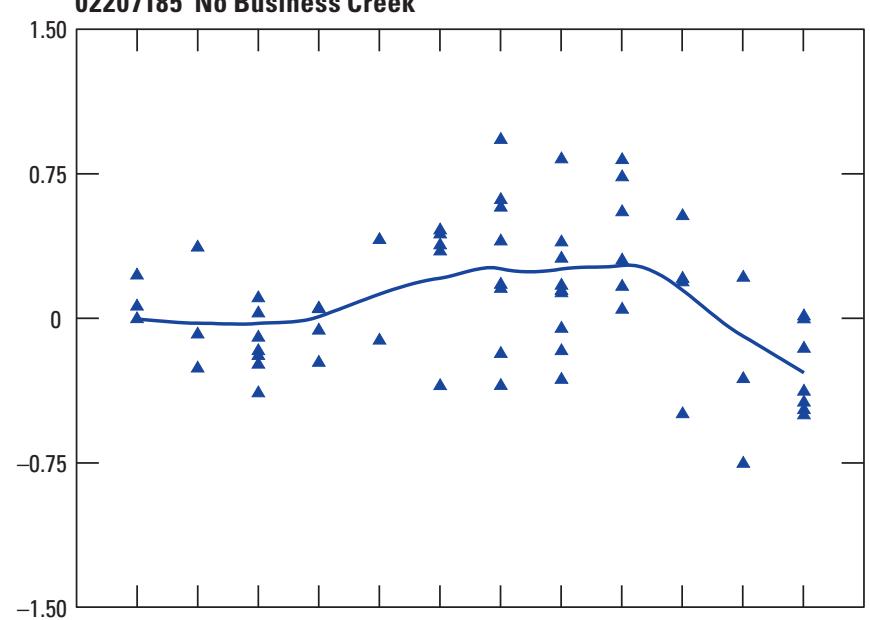

02207400 Brushy Fork Creek

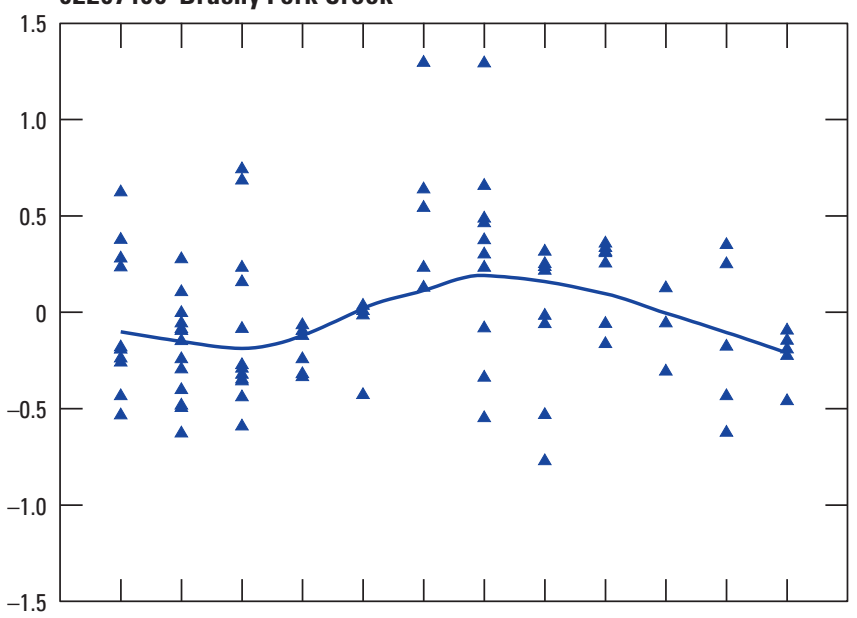

02217274 Wheeler Creek

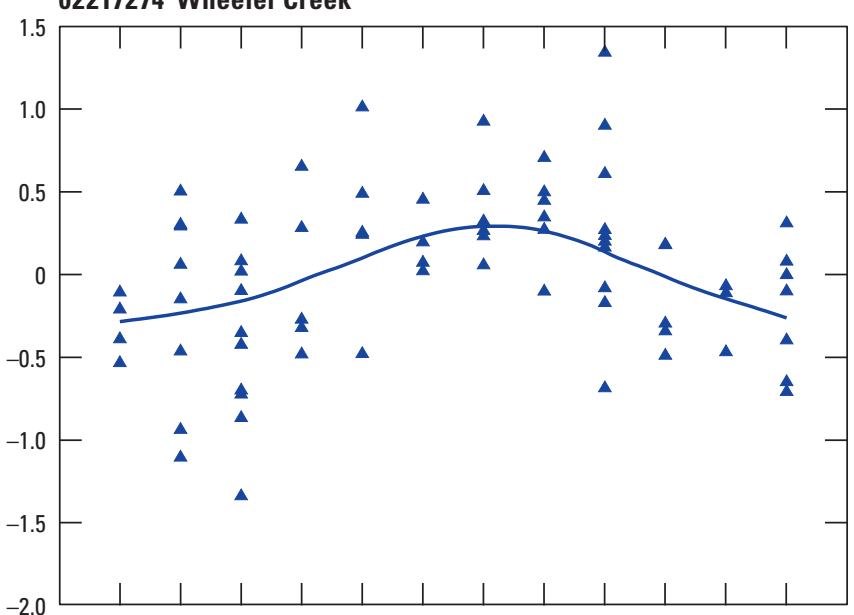

Jan. Feb. Mar. Apr. May June July Aug. Sept. Oct. Nov. Dec Month

Figure 22. Seasonal patterns in stormflow total suspended solids flow-adjusted residual concentrations for the 12 monitored watersheds in Gwinnett County, Georgia. A line representing a locally weighted regression and smoothing scatterplots (LOWESS) curve is shown to graphically identify the seasonal pattern. 
02218565 Apalachee River

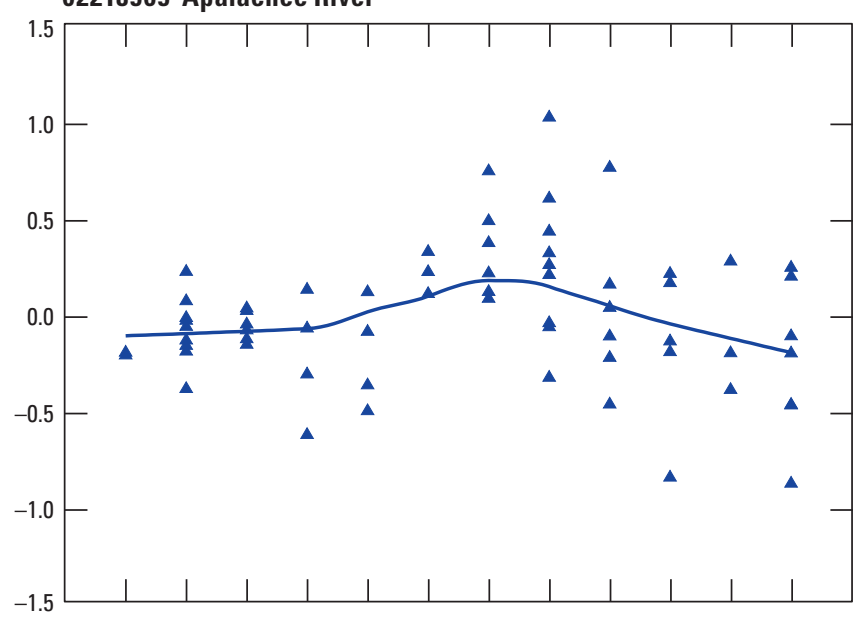

离

$-1.50$

02335350 Crooked Creek

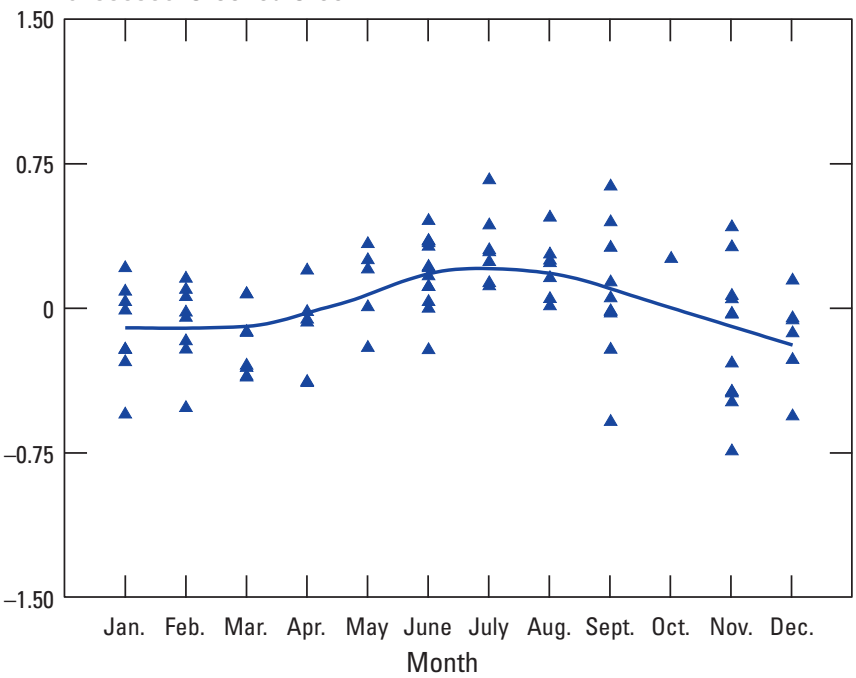

02334480 Richland Creek

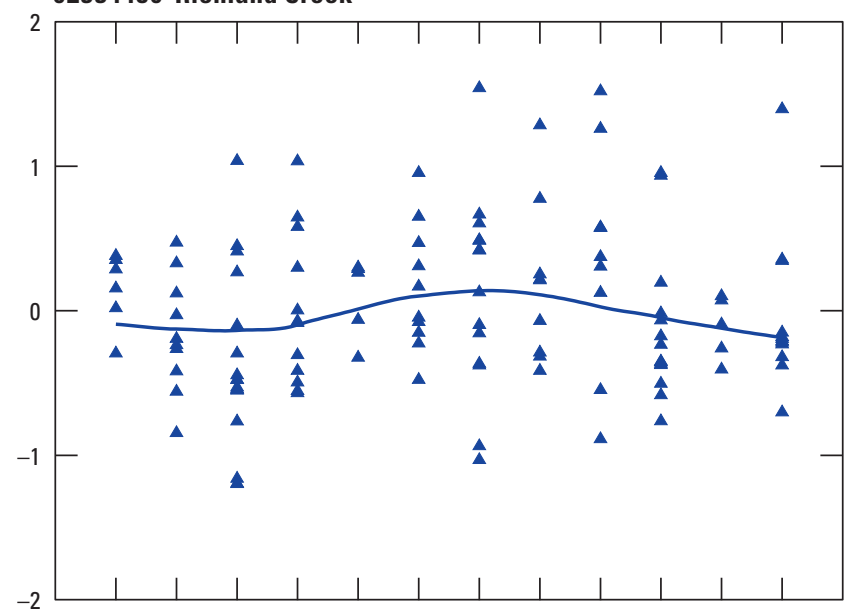

02334885 Suwanee Creek

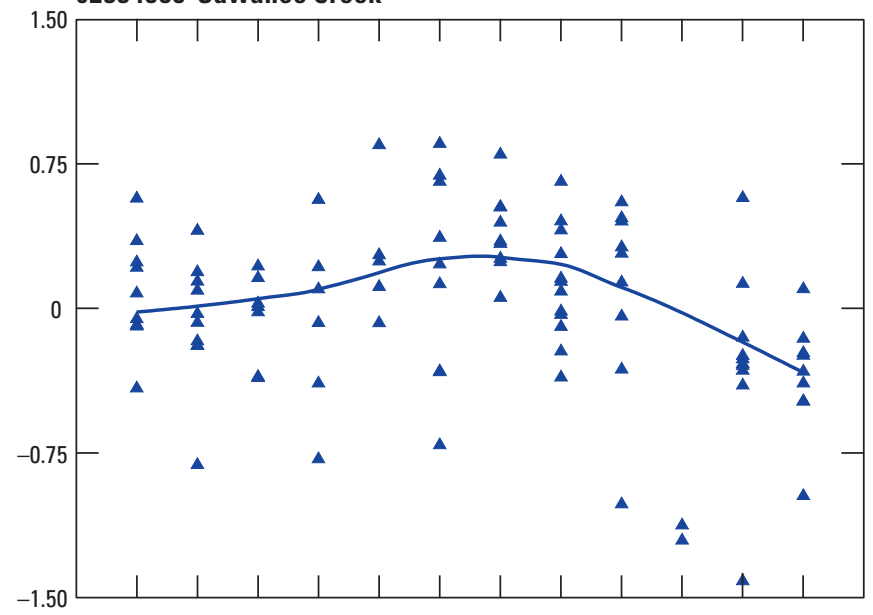

02336030 North Fork Peachtree Creek

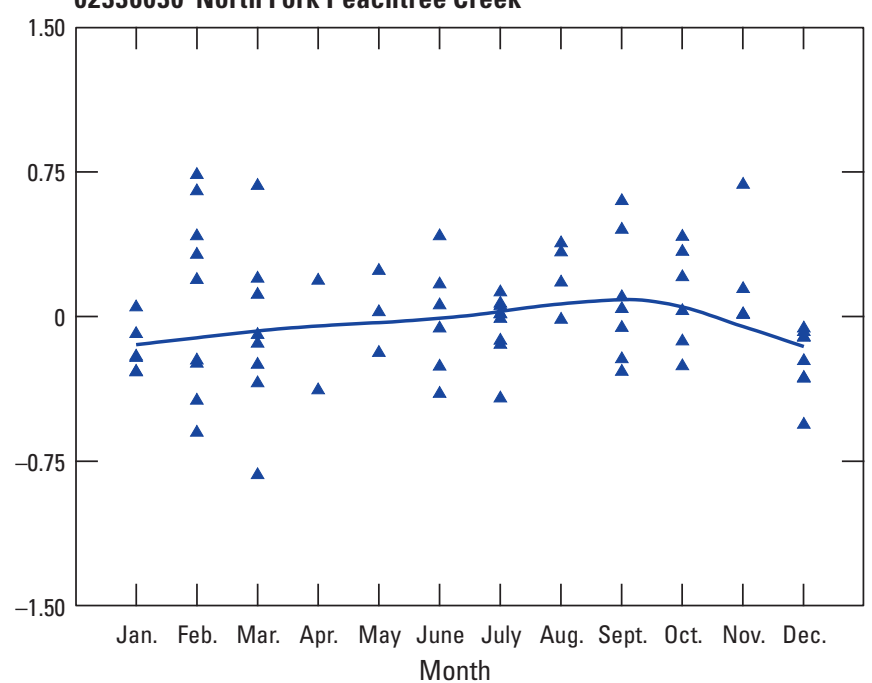

Figure 22. (Continued) Seasonal patterns in stormflow total suspended solids flow-adjusted residual concentrations for the 12 monitored watersheds in Gwinnett County, Georgia. A line representing a locally weighted regression and smoothing scatterplots (LOWESS) curve is shown to graphically identify the seasonal pattern. 
02207120 Yellow River

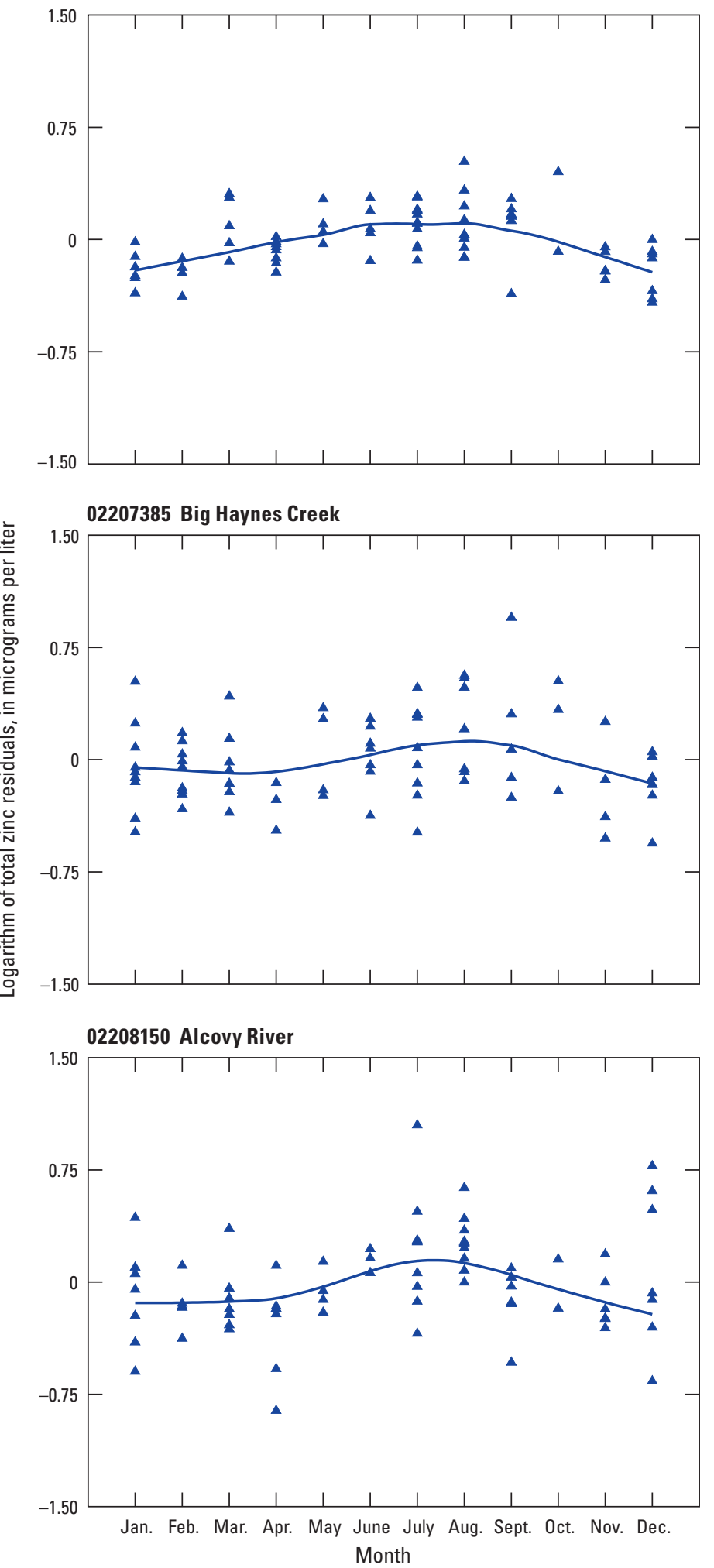

02207185 No Business Creek

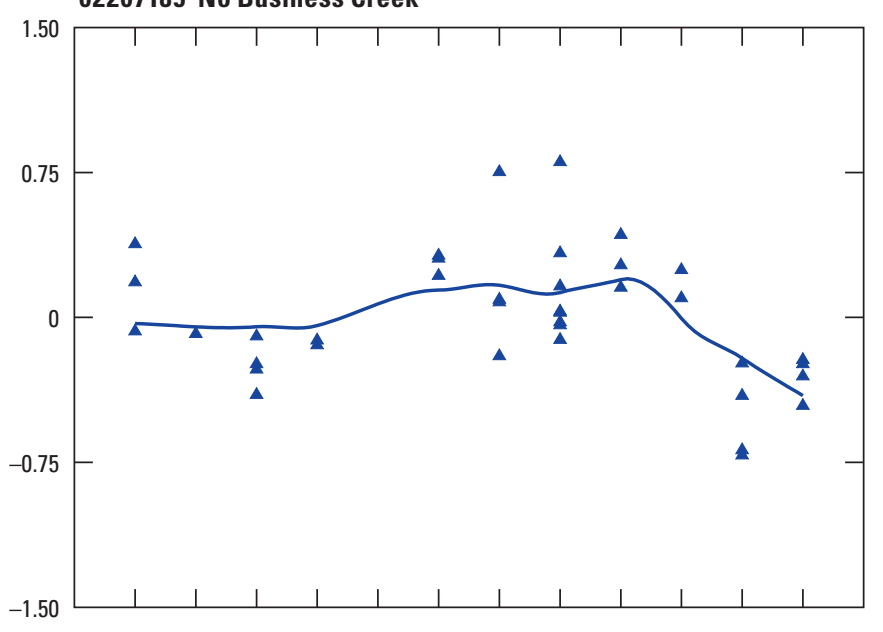

02207400 Brushy Fork Creek

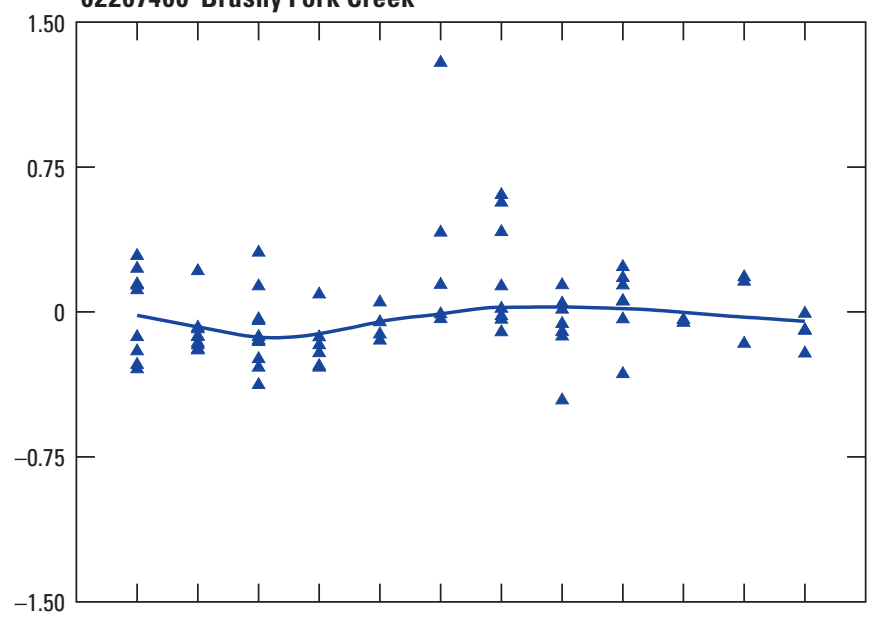

02217274 Wheeler Creek

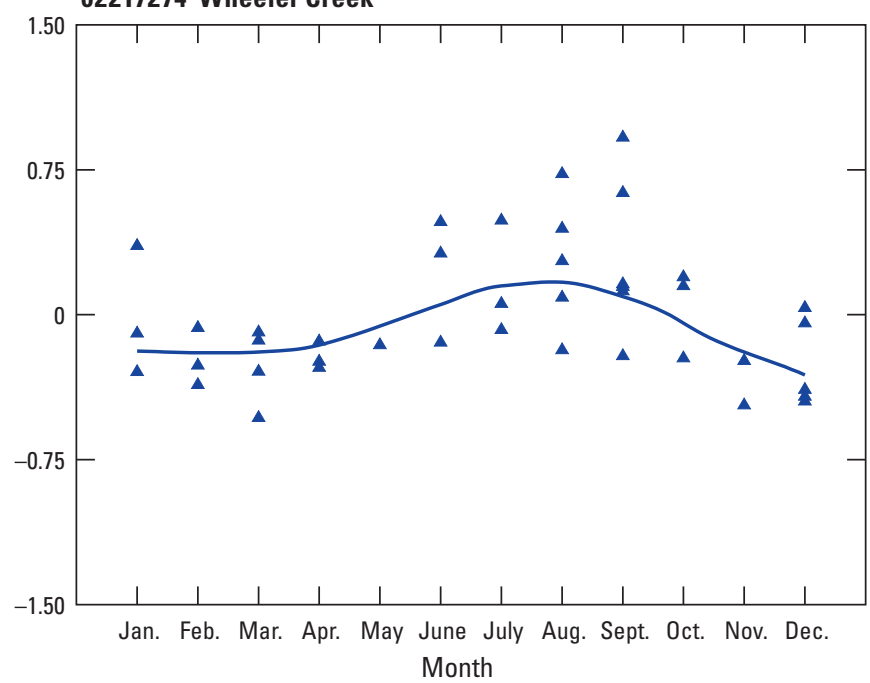

Figure 23. Seasonal patterns in stormflow total zinc flow-adjusted residual concentrations for the 12 monitored watersheds in Gwinnett County, Georgia. A line representing a locally weighted regression and smoothing scatterplots (LOWESS) curve is shown to graphically identify the seasonal pattern. 

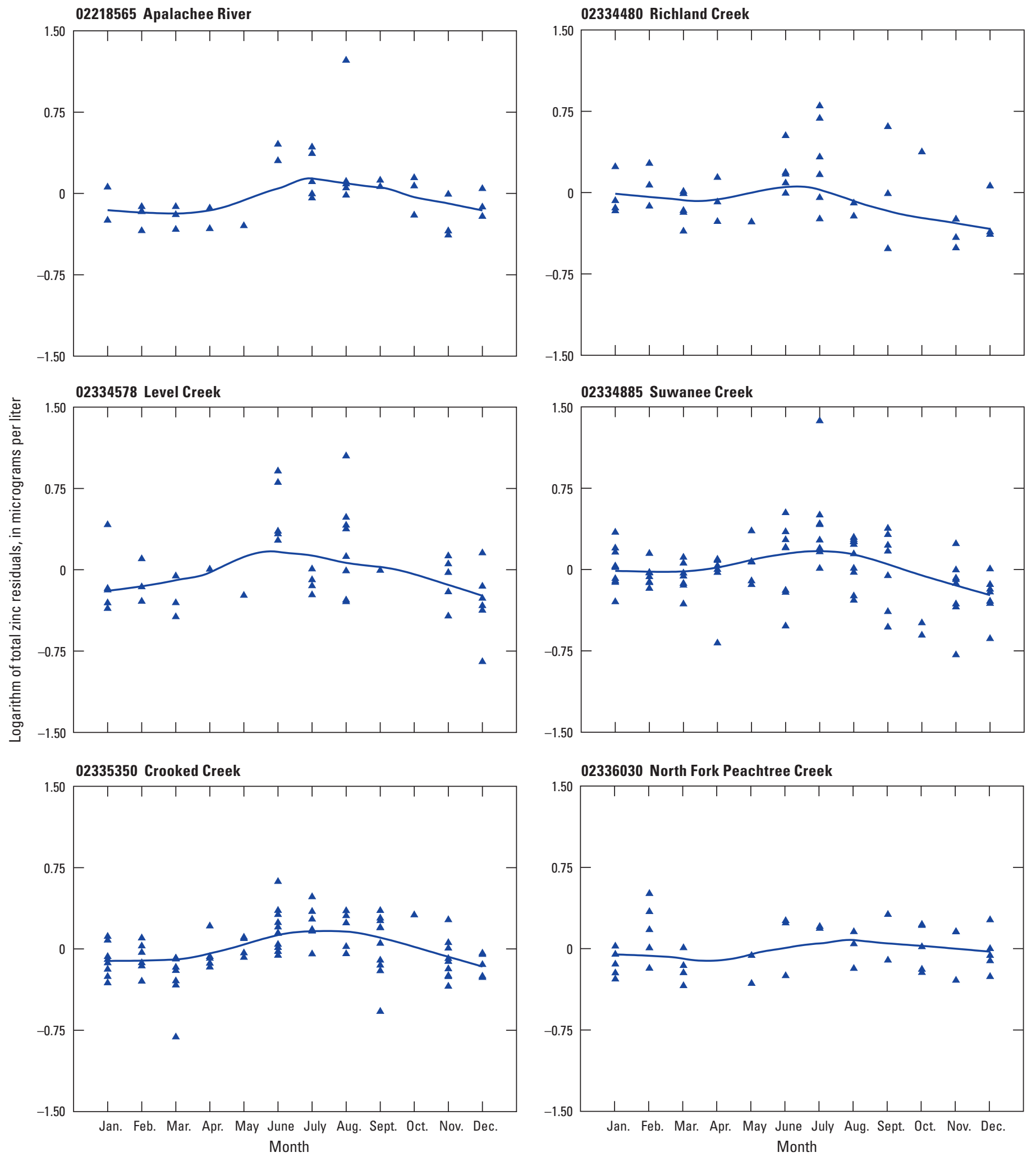

Figure 23. (Continued) Seasonal patterns in stormflow total zinc flow-adjusted residual concentrations for the 12 monitored watersheds in Gwinnett County, Georgia. A line representing a locally weighted regression and smoothing scatterplots (LOWESS) curve is shown to graphically identify the seasonal pattern. 


\section{Long-Term Trends in Water Quality}

Long-term trends in TN, TP, TDS, TSS and Zn were assessed for both base-flow and storm-event flow- and seasonally adjusted residual concentrations. Long-term trends were considered to be significant when the linear time explanatory variable in the regression equations used for load estimation was significant for a $p$-value of less than or equal to 0.1 . A trend analysis of annual runoff for the same periods as the water-quality trend analysis indicated no significant long-term trends in runoff. Trends in runoff may result in trends in waterquality constituents that are the result of climatic variability.

Base-flow residuals did not exhibit any significant long-term trends for any of the five constituents or for any of the 12 watersheds; however, long-term trends in storm-event flow- and seasonally adjusted residual concentrations occurred frequently. For the 12 watersheds and five constituent combinations (60 "cases"), no trend (NT) occurred in 24 cases, an increasing trend $(+)$ occurred in 9 cases, and a decreasing trend (-) occurred in 27 cases (table 4). Trends were detected in almost equal frequency whether the trends represented a 10 - to 11 -year period (11 of 30 cases had trends) or a 15 -year period (13 of 30 cases had trends), indicating that the period of record may not have been an important factor in determining whether or not a trend was detected.
Stormflow TN, TP, TDS, TSS, and Zn flow- and seasonally adjusted residual concentrations are plotted in relation to time for each watershed (figs. 24-28). A linear least-squares trend line is shown on plots that had significant trends. For $\mathrm{TN}$, Suwanee Creek has an increasing trend whereas four of the watersheds-No Business Creek, Big Haynes Creek, Apalachee River, and North Fork Peachtree Creek-have a decreasing trend. The slopes of the trend lines are small, indicating that the changes are minimal.

Trends in storm-event TP residuals were consistent across the county, with all but one of the watersheds having decreasing trends (fig. 25; table 4). No Business Creek watershed showed no significant trend. The slopes of the trend lines are small, indicating that the changes are minimal.

Seven of 12 watersheds exhibited increasing trends in stormflow TDS residuals (Yellow River, Brushy Fork Creek, Alcovy River, Wheeler Creek, Apalachee River, Level Creek, and Suwanee Creek), whereas one watershed (No Business Creek) had a decreasing trend (fig. 26; table 4). Unlike TN and TP, the TDS trends typically were increasing and the slopes of the trend lines were greater, indicating that TDS trends were likely the result of trends in dissolved constituents rather than the dissolved components of TN and TP.

Table 4. Water-quality constituent trends and statistical significance for stormflow samples in 12 monitored watersheds in Gwinnett County, Georgia.

[p-value, probability of statistical significance; NT, no significant linear trend, p-value greater than $0.10 ;+$, positive or upward trend; -, negative or downward trend; $<$, less than]

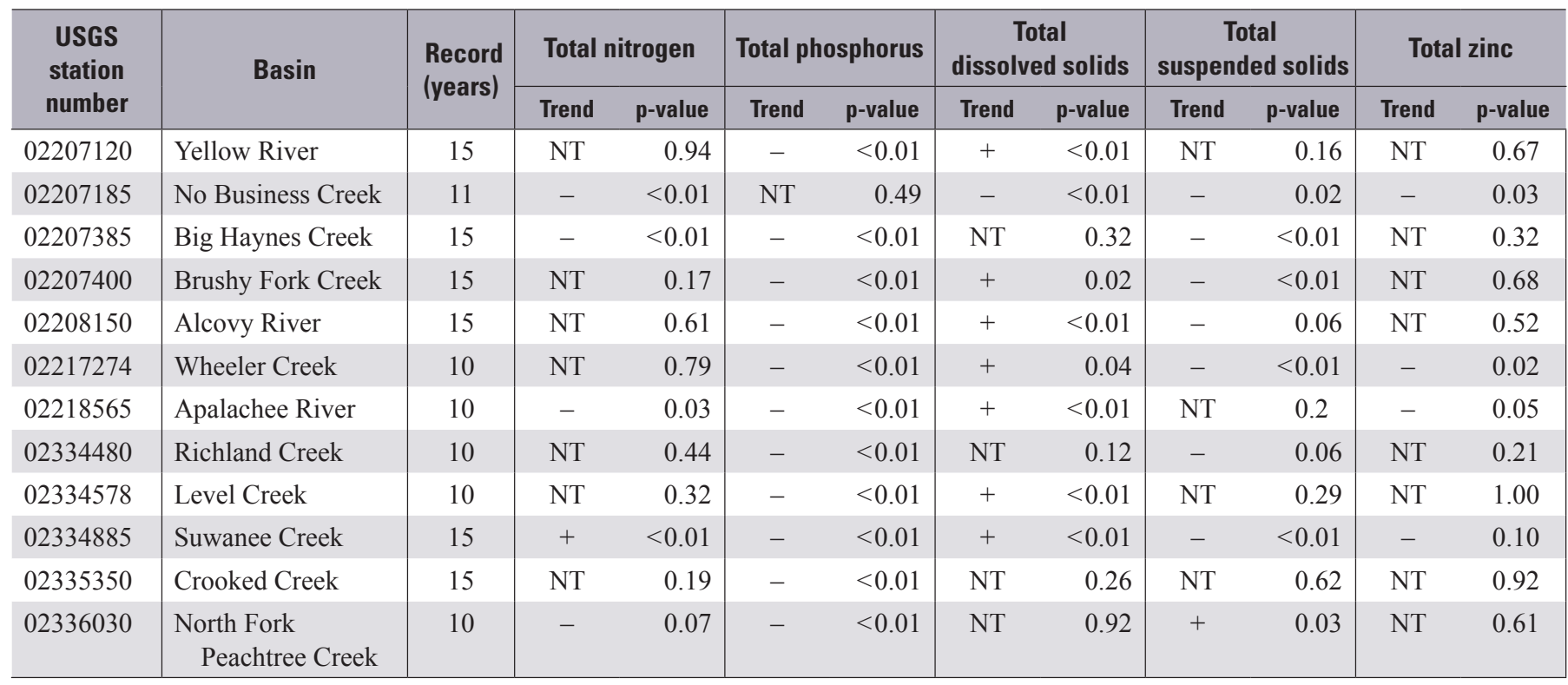



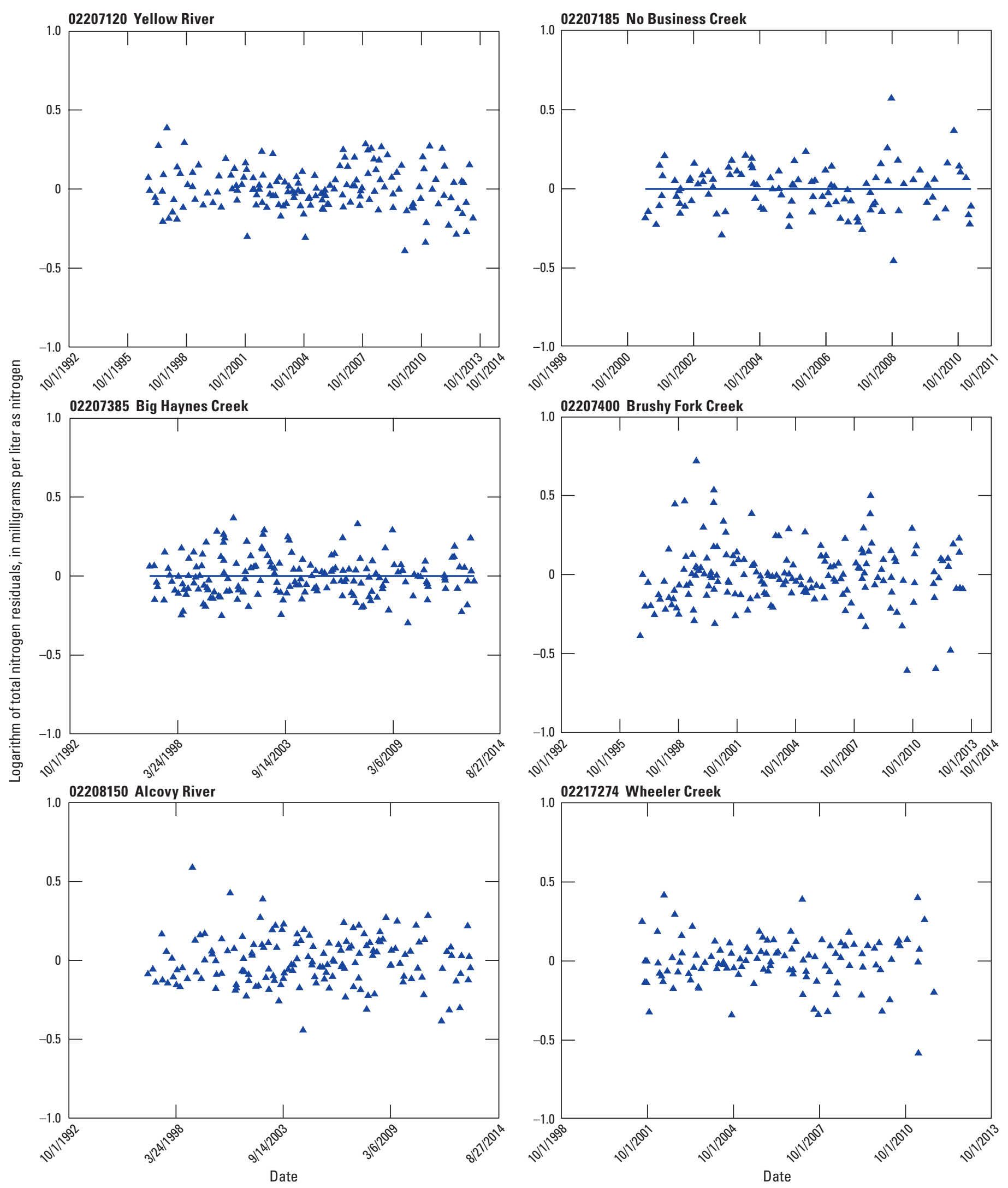

Figure 24. Trends in stormflow total nitrogen flow- and seasonally adjusted residual concentrations for the 12 monitored watersheds in Gwinnett County, Georgia. Stations with statistically significant trends ( $p$-value $>=0.10$ ) have a least-squares trend line to graphically identify the trend. 

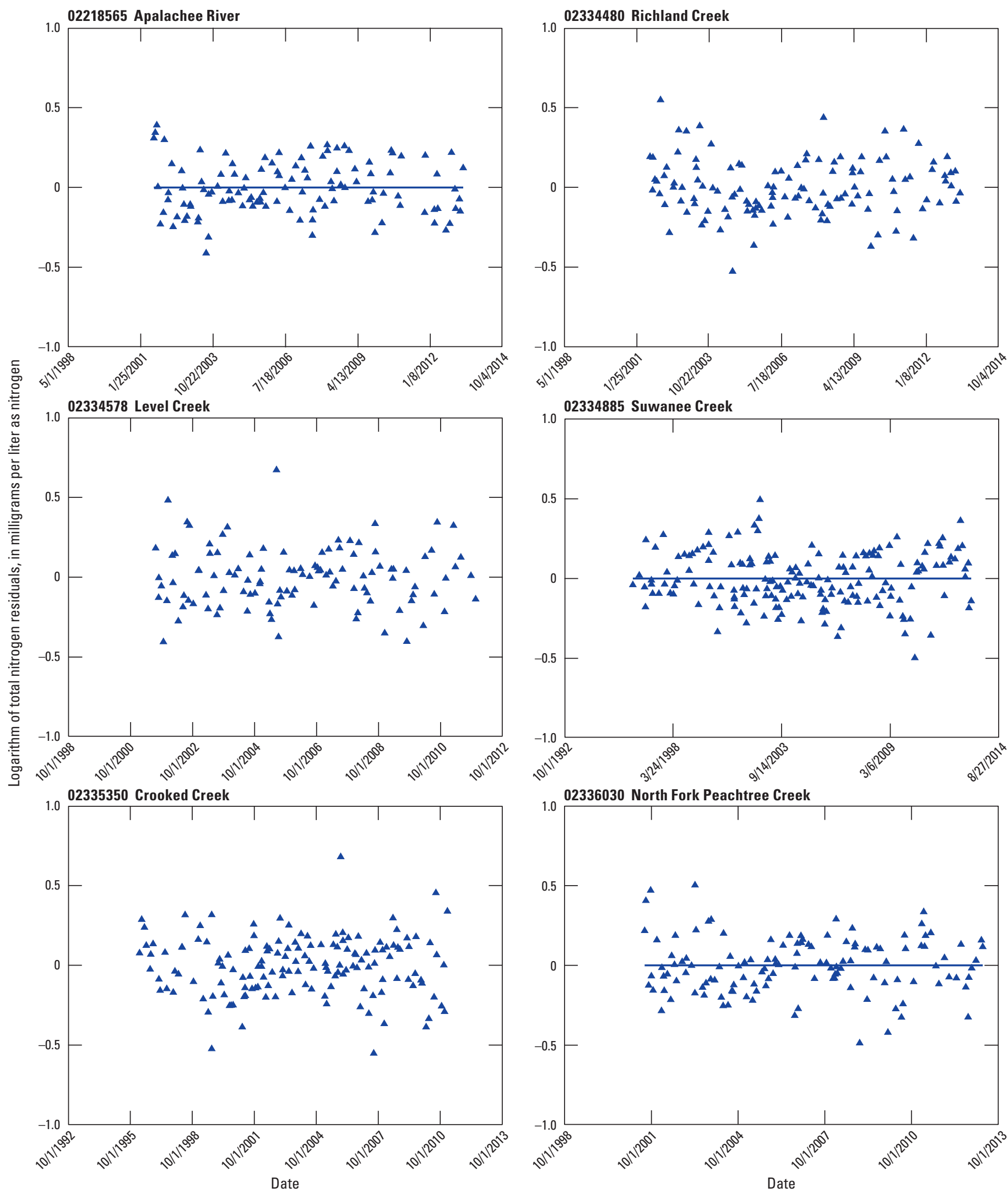

Figure 24. (Continued) Trends in stormflow total nitrogen flow- and seasonally adjusted residual concentrations for the 12 monitored watersheds in Gwinnett County, Georgia. Stations with statistically significant trends ( $p$-value $>=0.10$ ) have a leastsquares trend line to graphically identify the trend. 

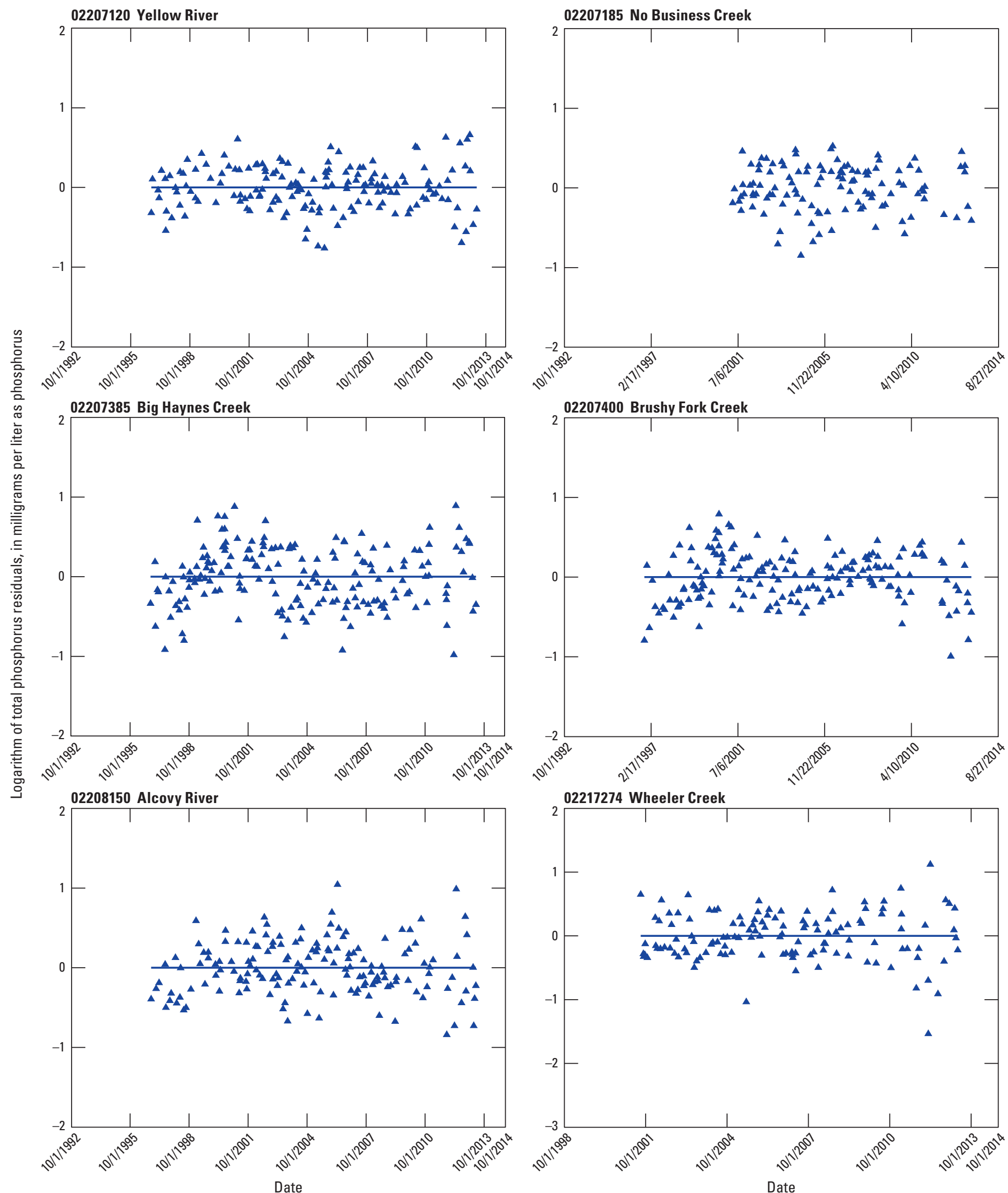

Figure 25. Trends in stormflow total phosphorus flow- and seasonally adjusted residual concentrations for the 12 monitored watersheds in Gwinnett County, Georgia. Stations with statistically significant trends ( $p$-value $>=0.10$ ) have a least-squares trend line to graphically identify the trend. 

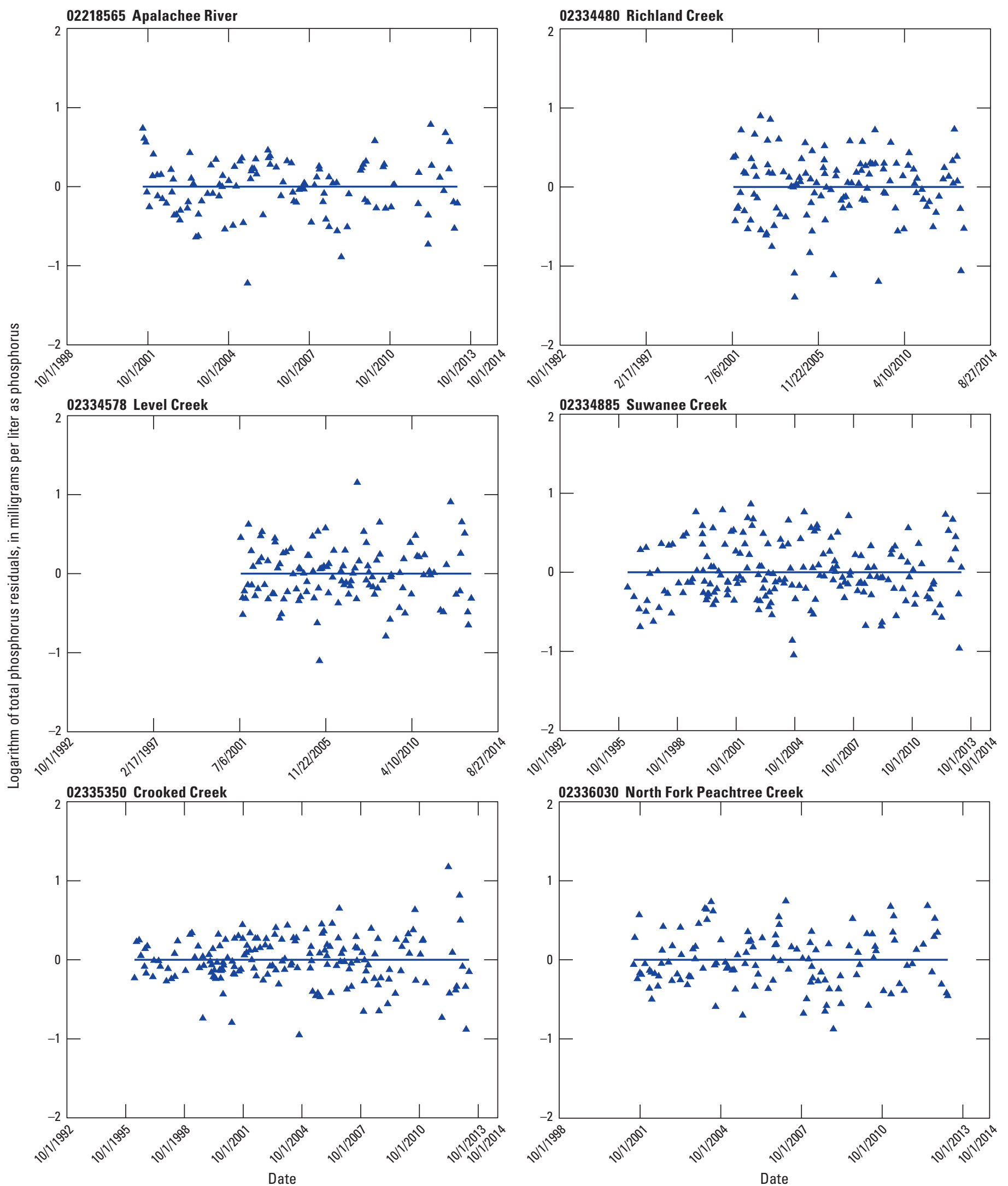

Figure 25. (Continued) Trends in stormflow total phosphorus flow- and seasonally adjusted residual concentrations for the 12 monitored watersheds in Gwinnett County, Georgia. Stations with statistically significant trends ( $p$-value $>=0.10$ ) have a leastsquares trend line to graphically identify the trend. 

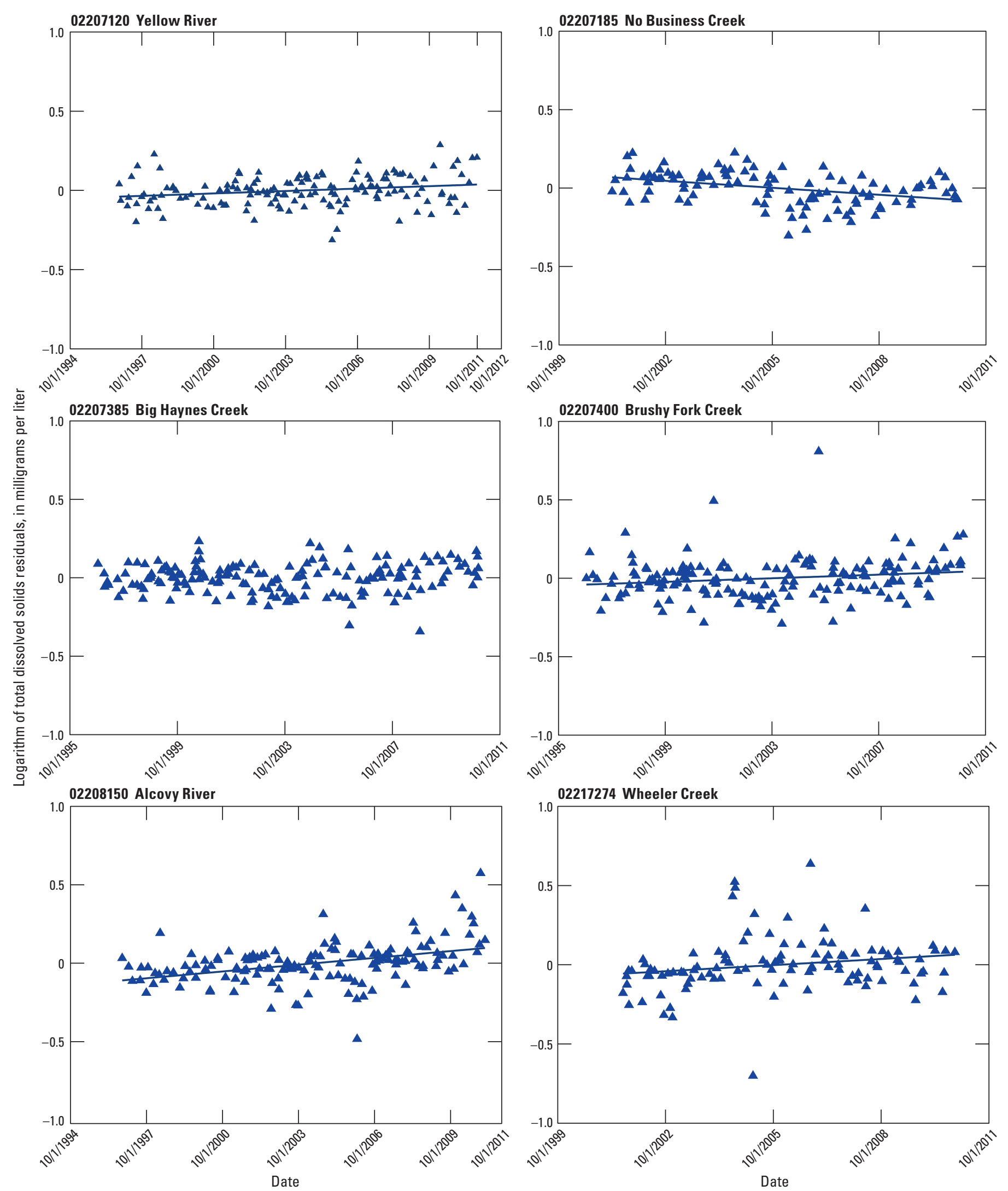

Figure 26. Trends in stormflow total dissolved solids flow- and seasonally adjusted residual concentrations for the 12 monitored watersheds in Gwinnett County, Georgia. Stations with statistically significant trends ( $p$-value $>=0.10)$ have a leastsquares trend line to graphically identify the trend. 

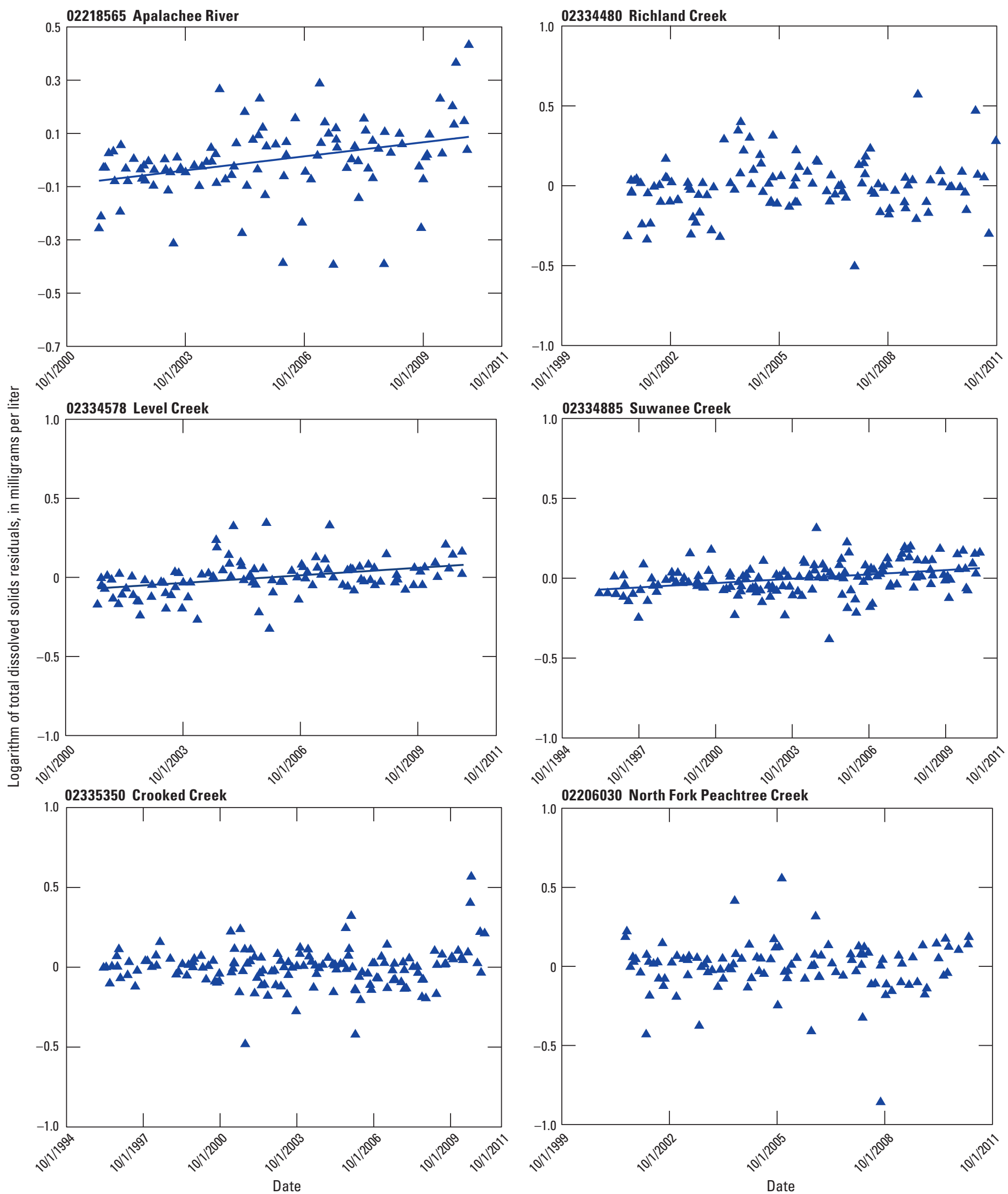

Figure 26. (Continued) Trends in stormflow total dissolved solids flow- and seasonally adjusted residual concentrations for the 12 monitored watersheds in Gwinnett County, Georgia. Stations with statistically significant trends ( $p$-value $>=0.10$ ) have a least-squares trend line to graphically identify the trend. 

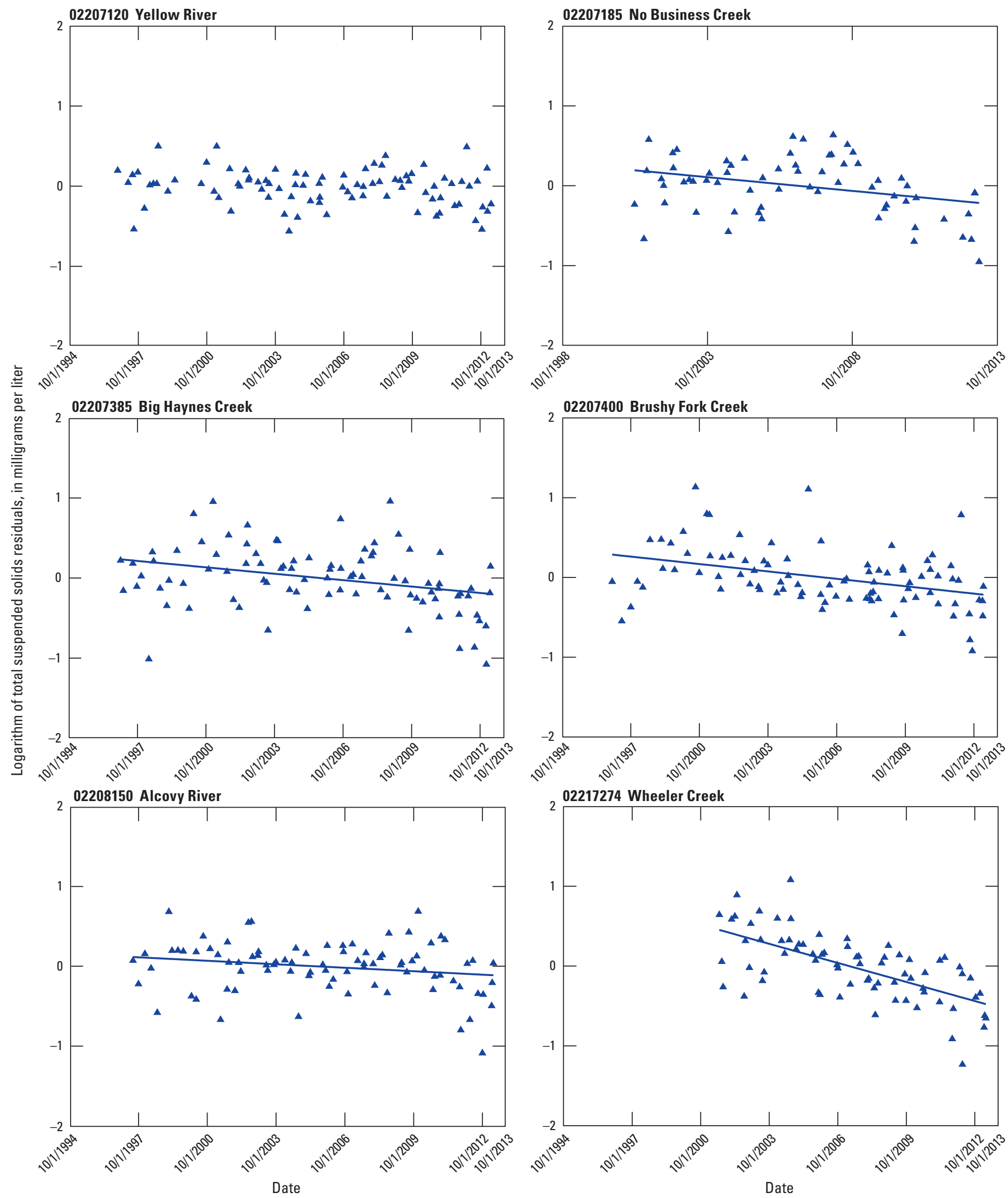

Figure 27. Trends in stormflow total suspended solids flow- and seasonally adjusted residual concentrations for the 12 monitored watersheds in Gwinnett County, Georgia. Stations with statistically significant trends ( $p$-value $>=0.10)$ have a leastsquares trend line to graphically identify the trend. 

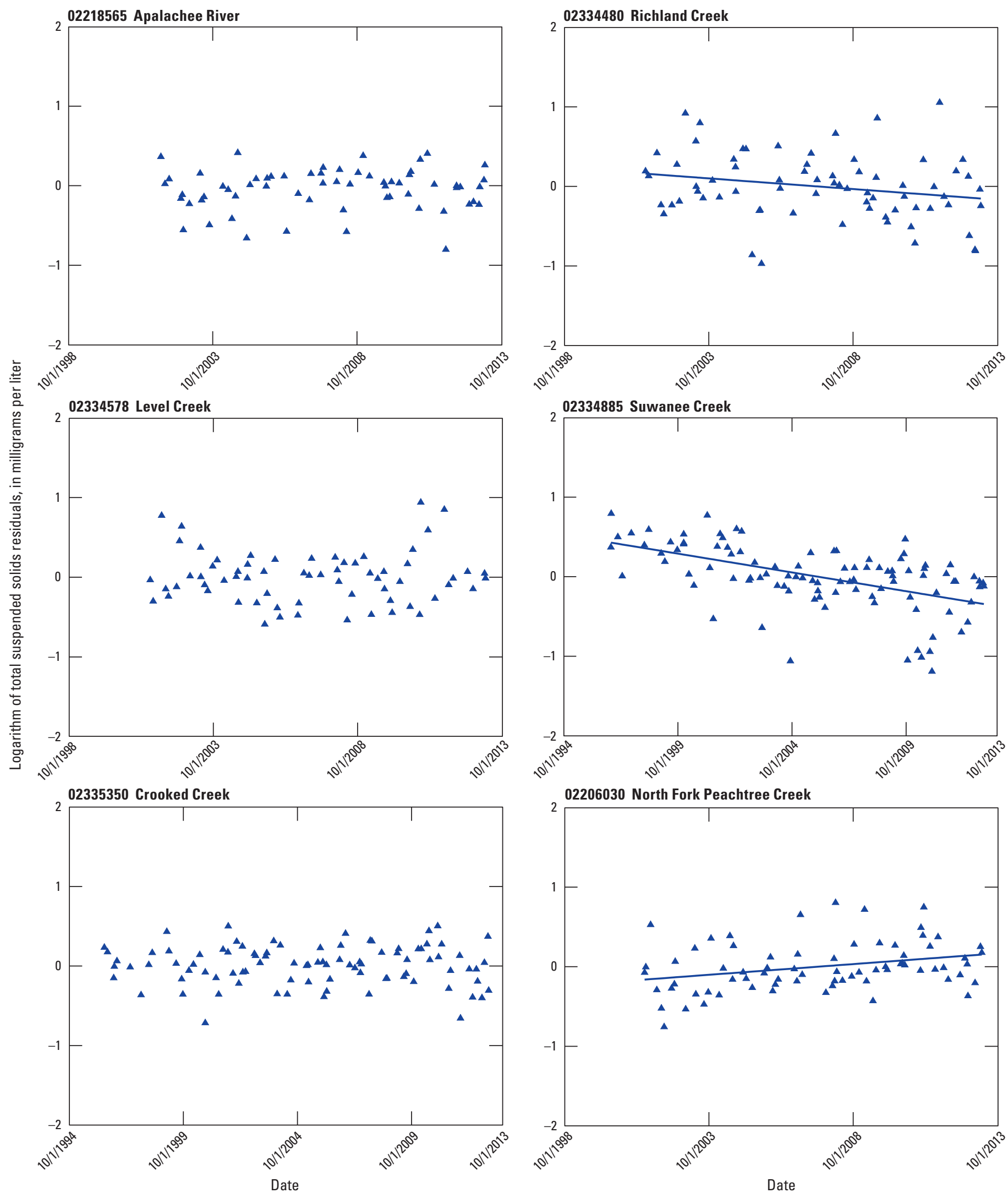

Figure 27. (Continued) Trends in stormflow total suspended solids flow- and seasonally adjusted residual concentrations for the 12 monitored watersheds in Gwinnett County, Georgia. Stations with statistically significant trends ( $p$-value $>=0.10$ ) have a least-squares trend line to graphically identify the trend. 

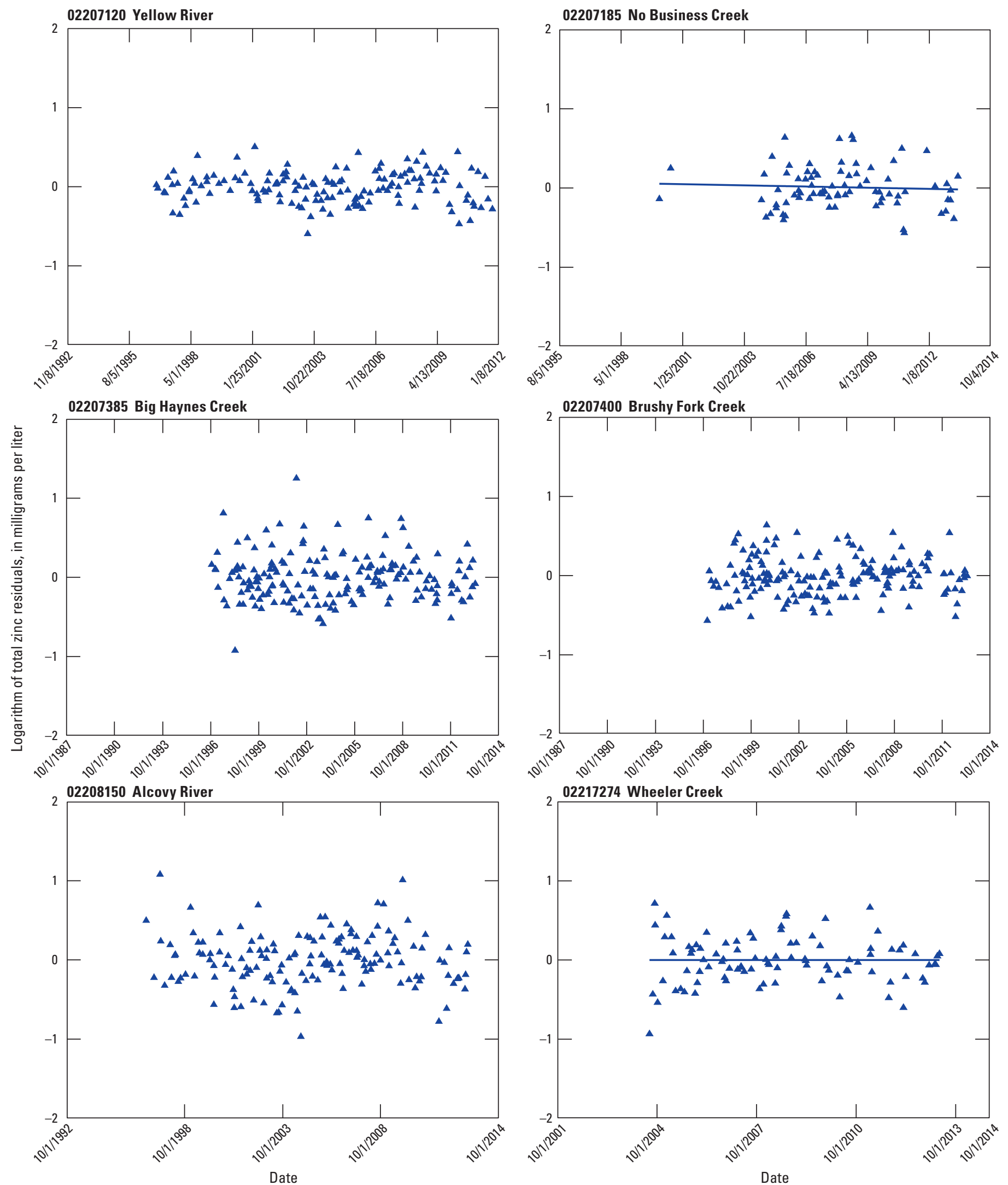

Figure 28. Trends in stormflow total zinc flow- and seasonally adjusted residual concentrations for the 12 monitored watersheds in Gwinnett County, Georgia. Stations with statistically significant trends ( $p$-value $>=0.10$ ) have a least-squares trend line to graphically identify the trend. 

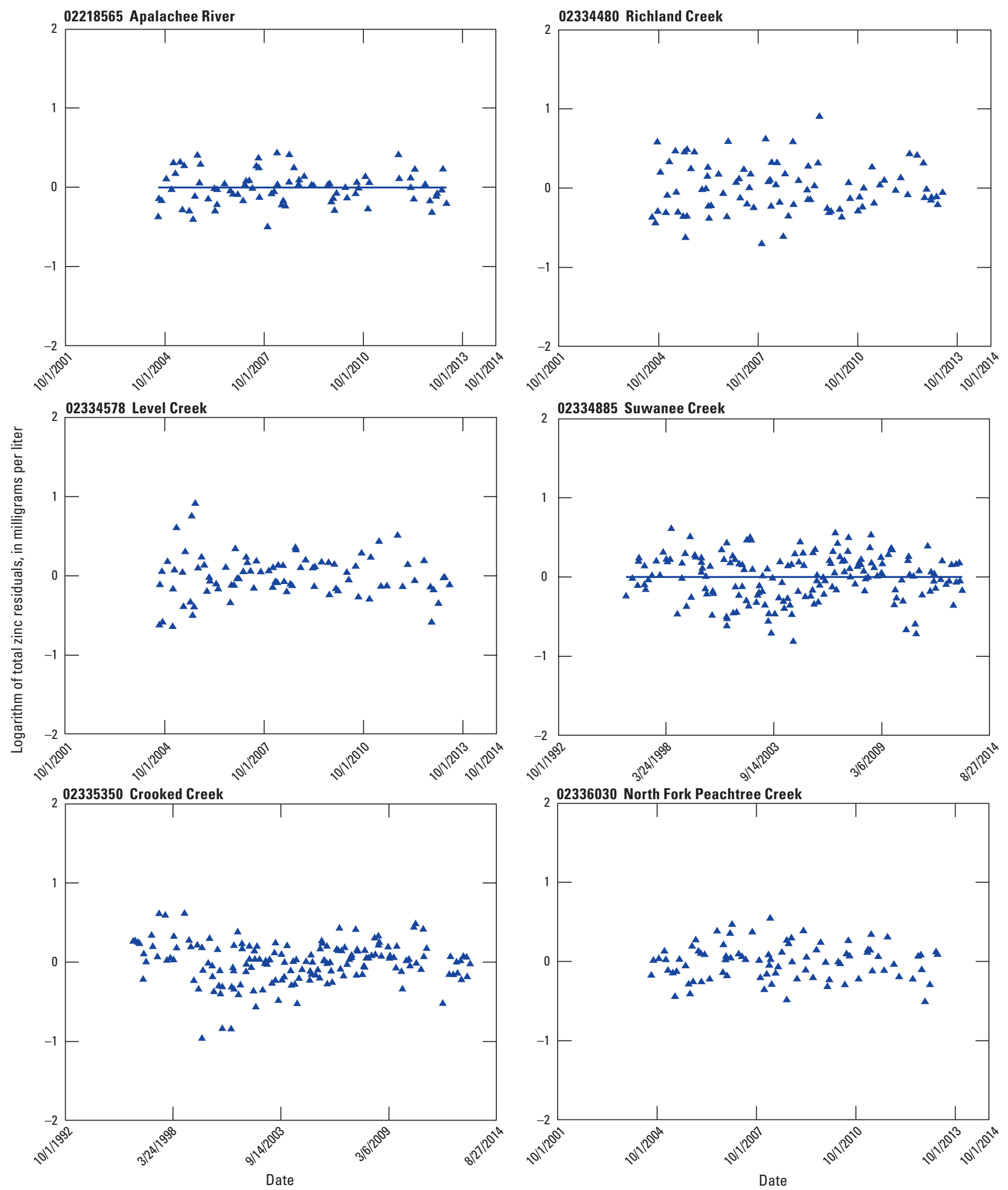

Figure 28. (Continued) Trends in stormflow total zinc flow- and seasonally adjusted residual concentrations for the 12 monitored watersheds in Gwinnett County, Georgia. Stations with statistically significant trends ( $p$-value $>=0.10$ ) have a leastsquares trend line to graphically identify the trend. 
For TSS, seven of the watersheds show decreasing trends-No Business Creek, Big Haynes Creek, Brushy Fork Creek, Alcovy River, Wheeler Creek, Richland Creek, and Suwanee Creek-and one watershed shows an increasing trend-North Fork Peachtree Creek (fig. 27; table 4). All trend slopes for TSS were much greater than those observed for TN and TP, with Wheeler Creek and Suwanee Creek watersheds having the highest rate of change in logarithmic residual concentrations per year (both decreasing trends). The decreasing TSS trends observed for seven of the watersheds is consistent with corresponding decreasing trends observed for $\mathrm{TP}$, but the rates of change were much higher for TSS.

The large decreasing trends in TSS at Wheeler Creek and Suwanee Creek are in contrast with large increases in impervious areas observed at these watersheds during the timeframe of the trend analysis (fig. 11). The other three watersheds that exhibited large increases in impervious areas have either no trends (Yellow River and Apalachee River) or decreasing trends (Alcovy Creek) in TSS. Gwinnett County has long implemented BMPs to reduce and mitigate the effects of impervious areas on sediment transport, and this practice may be affecting TSS concentrations over time. It is also still possible that climatic patterns may be playing a role in the TSS trends, even though no corresponding significant trends were found for annual runoff. Suspended-sediment concentrations and transport is controlled particularly by the magnitude of storm runoff, rather than the amount of annual runoff. Any trends in the variations of the frequency, magnitude, and duration of storm runoff have not been assessed in this study. Trends in total suspended solids could be the result of climatic patterns (changes in the magnitude, intensity, and duration of storms), changes in impervious areas, and the continued implementation of Gwinnett County's BMPs used to counteract the effects of impervious areas.

For total $\mathrm{Zn}$, four of the watersheds have decreasing trends-No Business Creek, Wheeler Creek, Apalachee River, and Suwanee Creek (fig. 28; table 4). Trends in TSS and Zn are consistent for No Business Creek, Wheeler Creek, and Suwanee Creek watersheds, with significant decreases for both TSS and Zn; however, the slopes of the $\mathrm{Zn}$ trend lines are small compared to the slopes of the TSS trend lines, indicating that the cause of changes in Zn and TSS may be different.

\section{Stream Water Loads and Yields}

Stream water constituent load is the mass of chemical solutes or sediment transported at a point in a stream during a set period of time. Load calculations essentially flow weight concentration variations throughout the measurement period, thereby integrating the effects of all processes within the watershed that temporally affect water quality. Yields are defined as loads per unit area and are used to allow easier comparison of the magnitude of loads among watersheds with different drainage areas.

Table 5 is a summary of the concentration regression models for $\mathrm{Zn}$ for all 12 watersheds. A pair of models is shown for each station - the model that includes turbidity is used unless turbidity data are missing. Although each model includes discharge, only some of the models include a discharge-squared term, seasonal terms, or time and timesquared long-term trend terms. The fitted model time step to address composite stormflow samples varied from 4 to 24 hours, depending on the watershed.

Figure 29 illustrates how the model was applied for base-flow and stormflow samples. Concentrations are plotted in relation to discharge, and regression lines show the fitted concentration-discharge relation. For the updated methodology used in this report, the slopes of the concentration-discharge relation for base-flow and stormflow samples are the same, but the relations still fit both types of samples. Tables 6 through 11 summarize the yields for WYs 2004 through 2009, respectively, for each of the 12 monitored watersheds and 10 water-quality constituents.

The biggest factor related to the variability in annual loads and yields is the amount of annual runoff. For example, the variation shown in figure 30 for $\mathrm{NO}_{2}+\mathrm{NO}_{3}$ and $\mathrm{TN}$ is similar to the variation in annual runoff. For this same reason, loads and yields for WYs 2004-09 will likely be below average due to lower-than-average precipitation during this period (18-percent below average), which resulted in belowaverage runoff. 
Table 5. Examples of characteristics of regression models used to compute loads of total zinc (Zn) for the 12 monitored watersheds in Gwinnett County, Georgia.

[Discharge ${ }^{2}$, discharge-squared; Time $^{2}$, time-squared. Explanatory variables: X, variable used; —, variable not used]

\begin{tabular}{|c|c|c|c|c|c|c|c|c|c|c|c|c|}
\hline \multirow{2}{*}{$\begin{array}{l}\text { USGS } \\
\text { station } \\
\text { number }\end{array}$} & \multirow{2}{*}{$\begin{array}{l}\text { Number } \\
\text { of } \\
\text { samples }\end{array}$} & \multicolumn{2}{|c|}{$\begin{array}{l}\text { Type and number } \\
\text { of samples }\end{array}$} & \multirow{2}{*}{$\begin{array}{l}\text { Regression } \\
\qquad \mathbf{R}^{2}\end{array}$} & \multirow{2}{*}{$\begin{array}{l}\text { Record } \\
\text { (years) }\end{array}$} & \multirow{2}{*}{$\begin{array}{l}\text { Model } \\
\text { time step } \\
\text { (hours) }\end{array}$} & \multicolumn{6}{|c|}{ Explanatory variables } \\
\hline & & $\begin{array}{l}\text { Base } \\
\text { flow }\end{array}$ & $\begin{array}{l}\text { Storm- } \\
\text { flow }\end{array}$ & & & & Discharge & Turbidity & Discharge $^{2}$ & Season & Time & Time $^{2}$ \\
\hline 02207120 & 131 & 65 & 66 & 0.963 & 14 & 24 & $\mathrm{X}$ & - & $\mathrm{X}$ & $\mathrm{X}$ & $\mathrm{X}$ & - \\
\hline 02207120 & 131 & 65 & 66 & 0.969 & 14 & 24 & $\mathrm{X}$ & $\mathrm{X}$ & - & $\mathrm{X}$ & $\mathrm{X}$ & - \\
\hline 02207185 & 56 & 29 & 27 & 0.941 & 6 & 6 & $\mathrm{X}$ & - & - & $\mathrm{X}$ & $\mathrm{X}$ & - \\
\hline 02207185 & 56 & 29 & 27 & 0.95 & 6 & 6 & $\mathrm{X}$ & $\mathrm{X}$ & - & $\mathrm{X}$ & $\mathrm{X}$ & - \\
\hline 02207385 & 146 & 84 & 62 & 0.874 & 14 & 12 & $\mathrm{X}$ & - & - & $\mathrm{X}$ & $\mathrm{X}$ & - \\
\hline 02207385 & 146 & 84 & 62 & 0.965 & 14 & 12 & $\mathrm{X}$ & $\mathrm{X}$ & - & $\mathrm{X}$ & $\mathrm{X}$ & $\mathrm{X}$ \\
\hline 02207400 & 147 & 85 & 62 & 0.93 & 12 & 12 & $\mathrm{X}$ & - & - & $\mathrm{X}$ & - & - \\
\hline 02207400 & 145 & 85 & 60 & 0.956 & 12 & 12 & $\mathrm{X}$ & $X$ & - & - & $\mathrm{X}$ & $X$ \\
\hline 02208150 & 125 & 59 & 66 & 0.948 & 14 & 8 & $X$ & - & $\mathrm{X}$ & $X$ & $\mathrm{X}$ & $\mathrm{X}$ \\
\hline 02208150 & 123 & 59 & 64 & 0.956 & 14 & 8 & $\mathrm{X}$ & $\mathrm{X}$ & $\mathrm{X}$ & $\mathrm{X}$ & $\mathrm{X}$ & $\mathrm{X}$ \\
\hline 02217274 & 61 & 29 & 32 & 0.943 & 6 & 8 & $\mathrm{X}$ & - & $\mathrm{X}$ & $\mathrm{X}$ & - & - \\
\hline 02217274 & 61 & 29 & 32 & 0.962 & 6 & 8 & $\mathrm{X}$ & $\mathrm{X}$ & - & $\mathrm{X}$ & $\mathrm{X}$ & $\mathrm{X}$ \\
\hline 02218565 & 52 & 27 & 25 & 0.976 & 6 & 4 & $\mathrm{X}$ & - & - & $\mathrm{X}$ & $\mathrm{X}$ & - \\
\hline 02218565 & 52 & 27 & 25 & 0.979 & 6 & 4 & $\mathrm{X}$ & $X$ & - & $\mathrm{X}$ & $\mathrm{X}$ & - \\
\hline 02334480 & 59 & 27 & 32 & 0.936 & 6 & 6 & $\mathrm{X}$ & - & $\mathrm{X}$ & - & - & - \\
\hline 02334480 & 59 & 27 & 32 & 0.948 & 6 & 6 & $\mathrm{X}$ & $\mathrm{X}$ & - & - & - & - \\
\hline 02334578 & 58 & 28 & 30 & 0.953 & 6 & 6 & $\mathrm{X}$ & - & - & $\mathrm{X}$ & $\mathrm{X}$ & - \\
\hline 02334578 & 58 & 28 & 30 & 0.964 & 6 & 6 & $\mathrm{X}$ & $\mathrm{X}$ & $\mathrm{X}$ & - & - & - \\
\hline 02334885 & 137 & 69 & 68 & 0.916 & 14 & 12 & $X$ & - & - & $X$ & $\mathrm{X}$ & $X$ \\
\hline 02334885 & 133 & 69 & 64 & 0.953 & 14 & 12 & $\mathrm{X}$ & $\mathrm{X}$ & $\mathrm{X}$ & - & $\mathrm{X}$ & $\mathrm{X}$ \\
\hline 02335350 & 128 & 66 & 62 & 0.961 & 14 & 6 & $\mathrm{X}$ & - & - & - & $\mathrm{X}$ & $\mathrm{X}$ \\
\hline 02335350 & 128 & 66 & 62 & 0.972 & 14 & 6 & $\mathrm{X}$ & $\mathrm{X}$ & - & - & $\mathrm{X}$ & $\mathrm{X}$ \\
\hline 02336030 & 57 & 28 & 29 & 0.975 & 6 & 4 & $\mathrm{X}$ & - & - & - & $\mathrm{X}$ & - \\
\hline 02336030 & 57 & 28 & 29 & 0.981 & 6 & 4 & $X$ & $\mathrm{X}$ & - & - & $\mathrm{X}$ & - \\
\hline
\end{tabular}




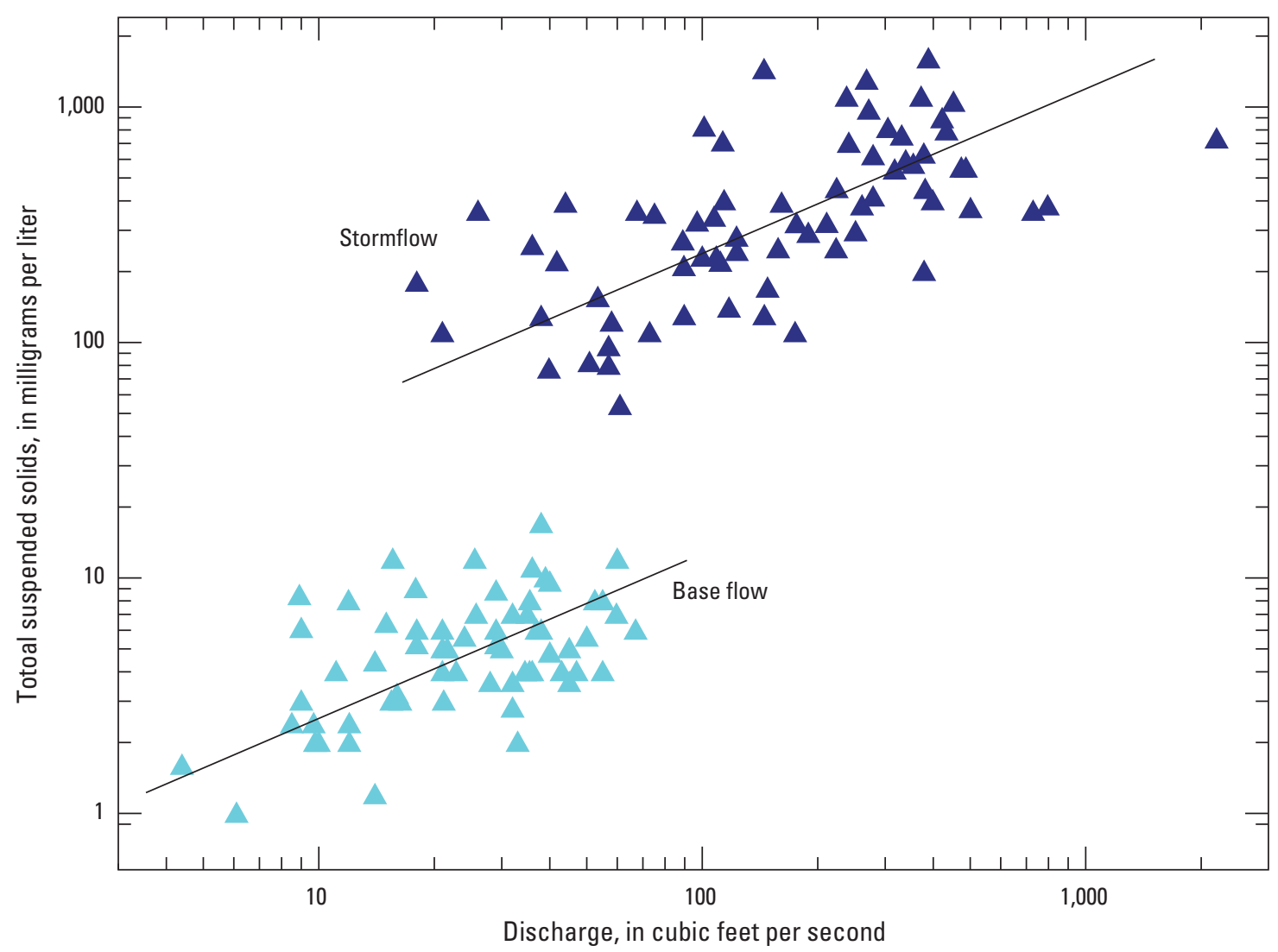

Figure 29. Total suspended solids in relation to discharge for base-flow and stormflow conditions for samples collected at station 02208150, Alcovy River near Grayson, Georgia, 1997-2009. Lines through data show general concentration discharge relation.

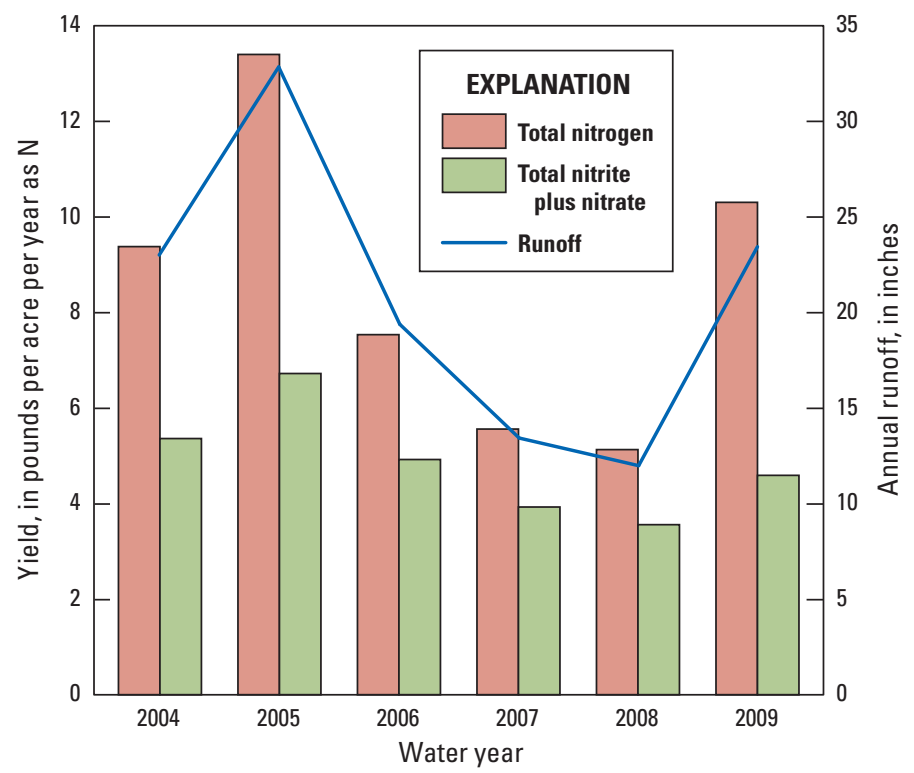

Figure 30. Average annual yields for total nitrite plus nitrate $\left(\mathrm{NO}_{2}+\mathrm{NO}_{3}\right)$ and total nitrogen, and annual runoff in Gwinnett County, Georgia, water years 2004-09. 


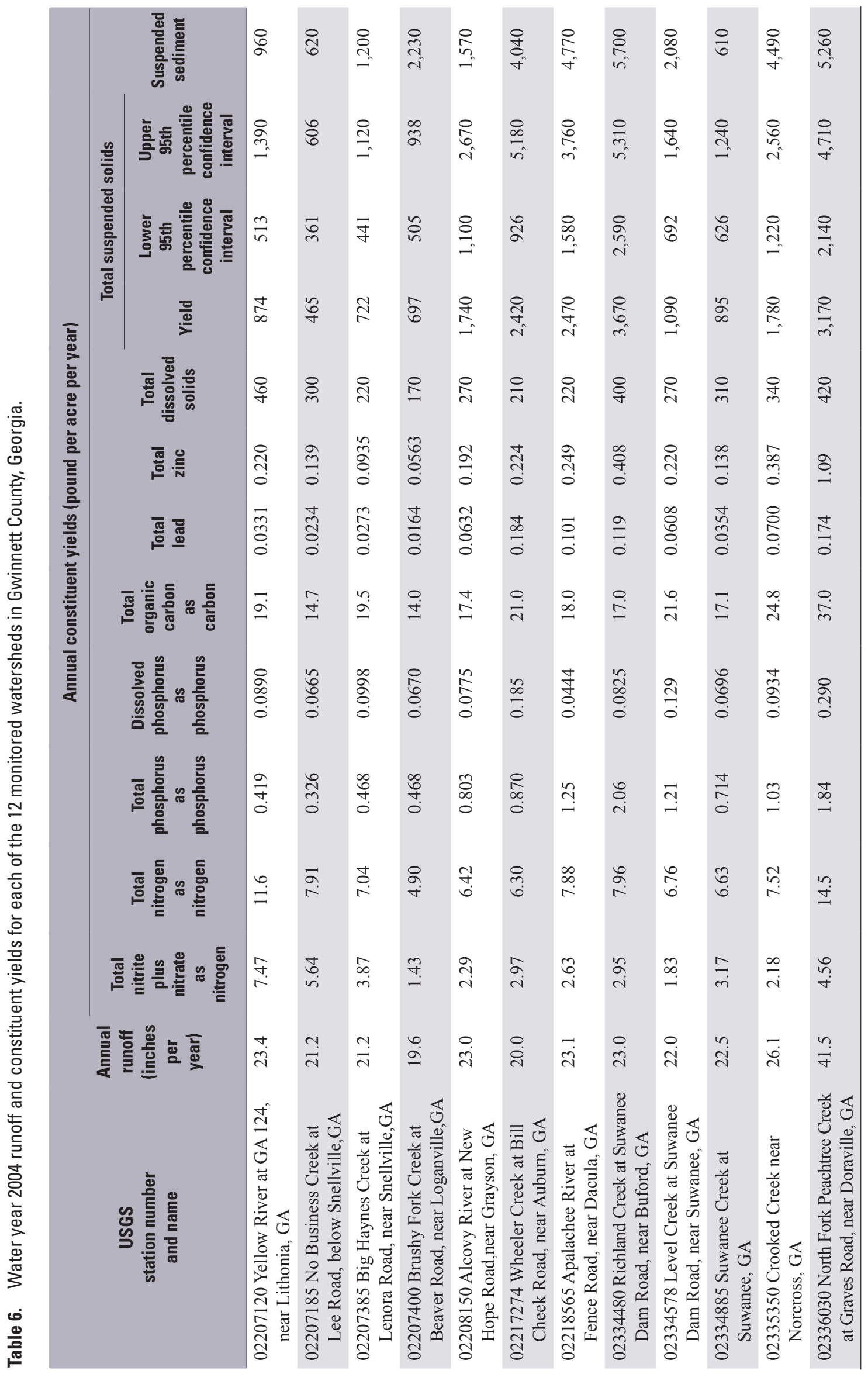




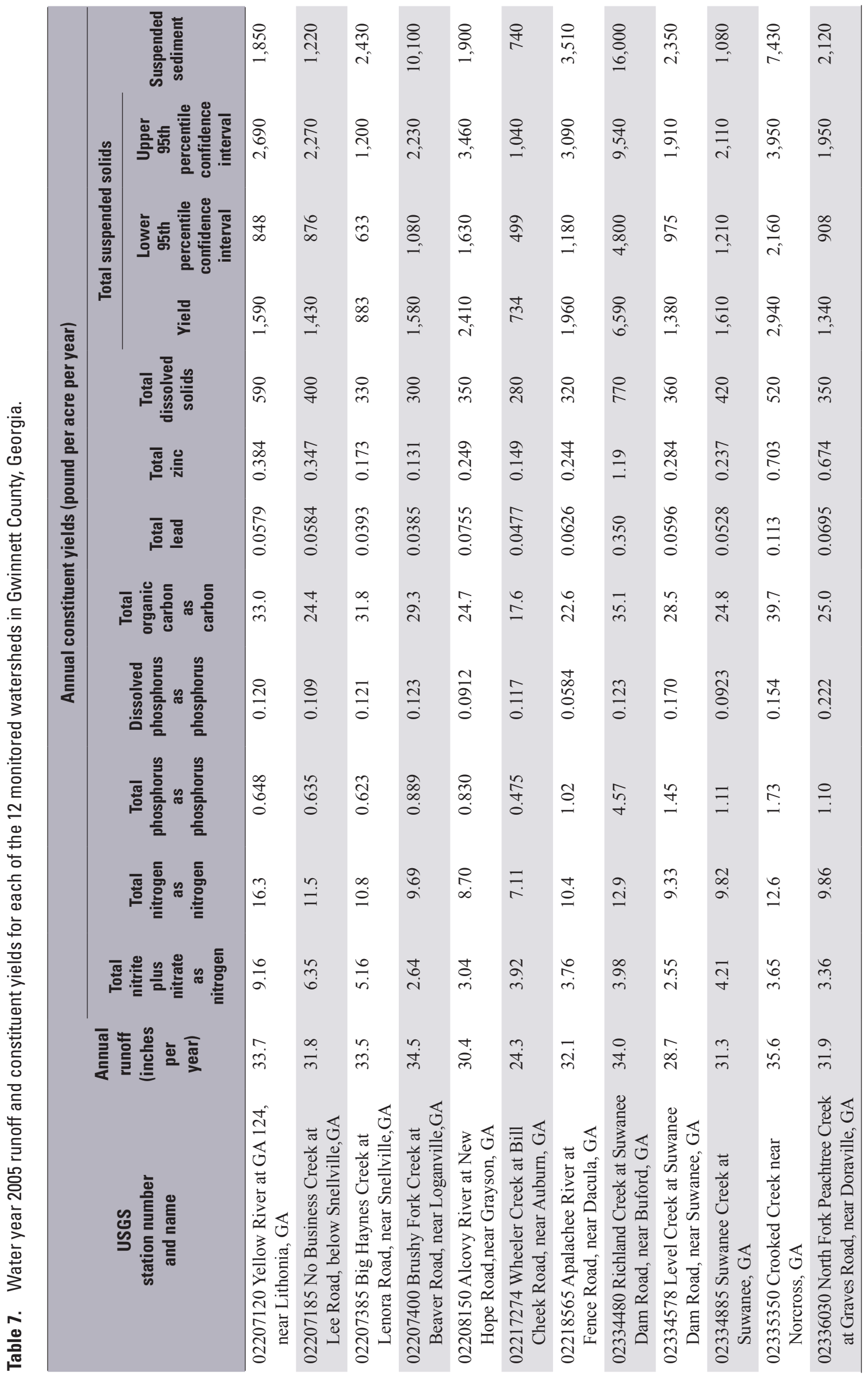




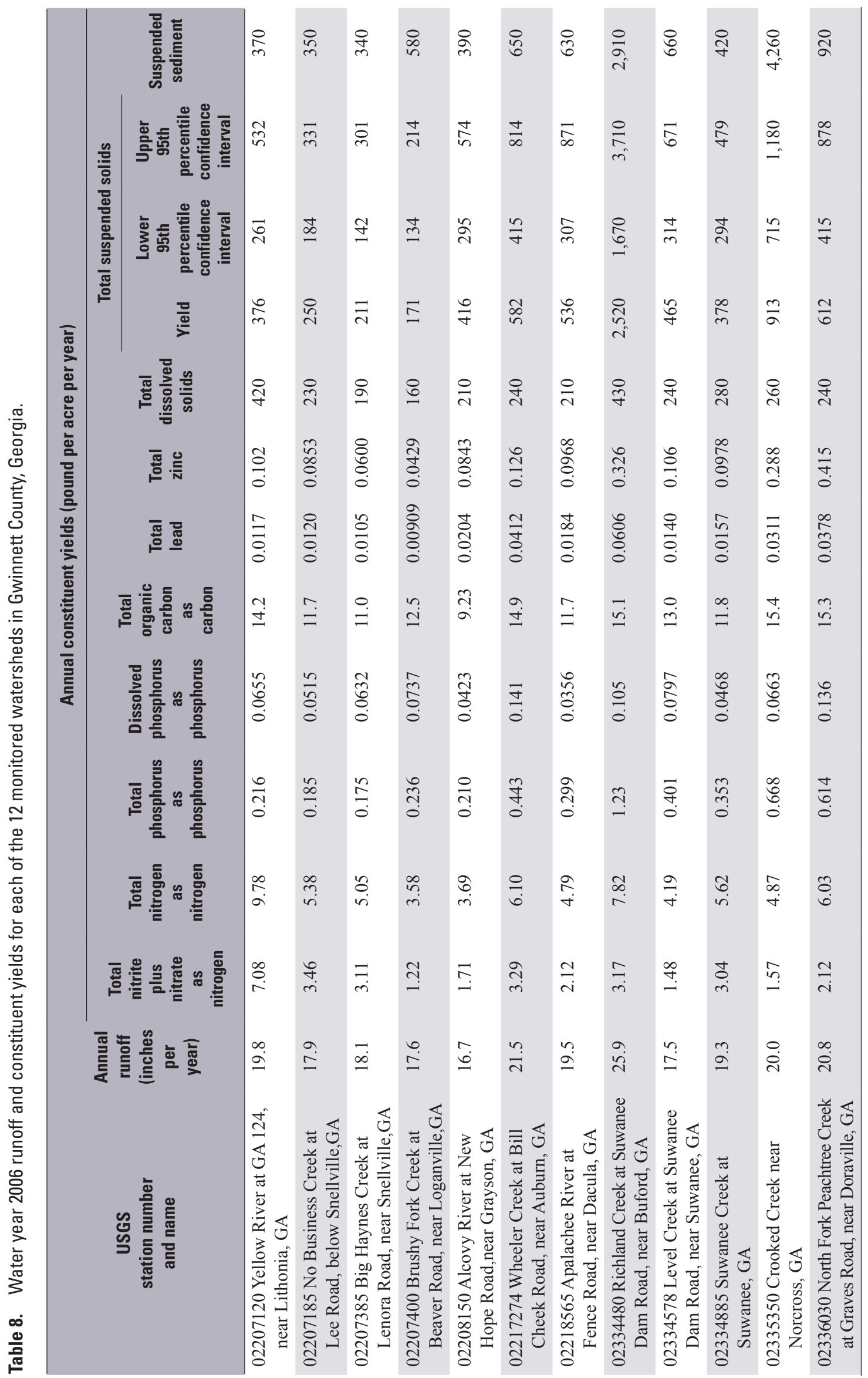




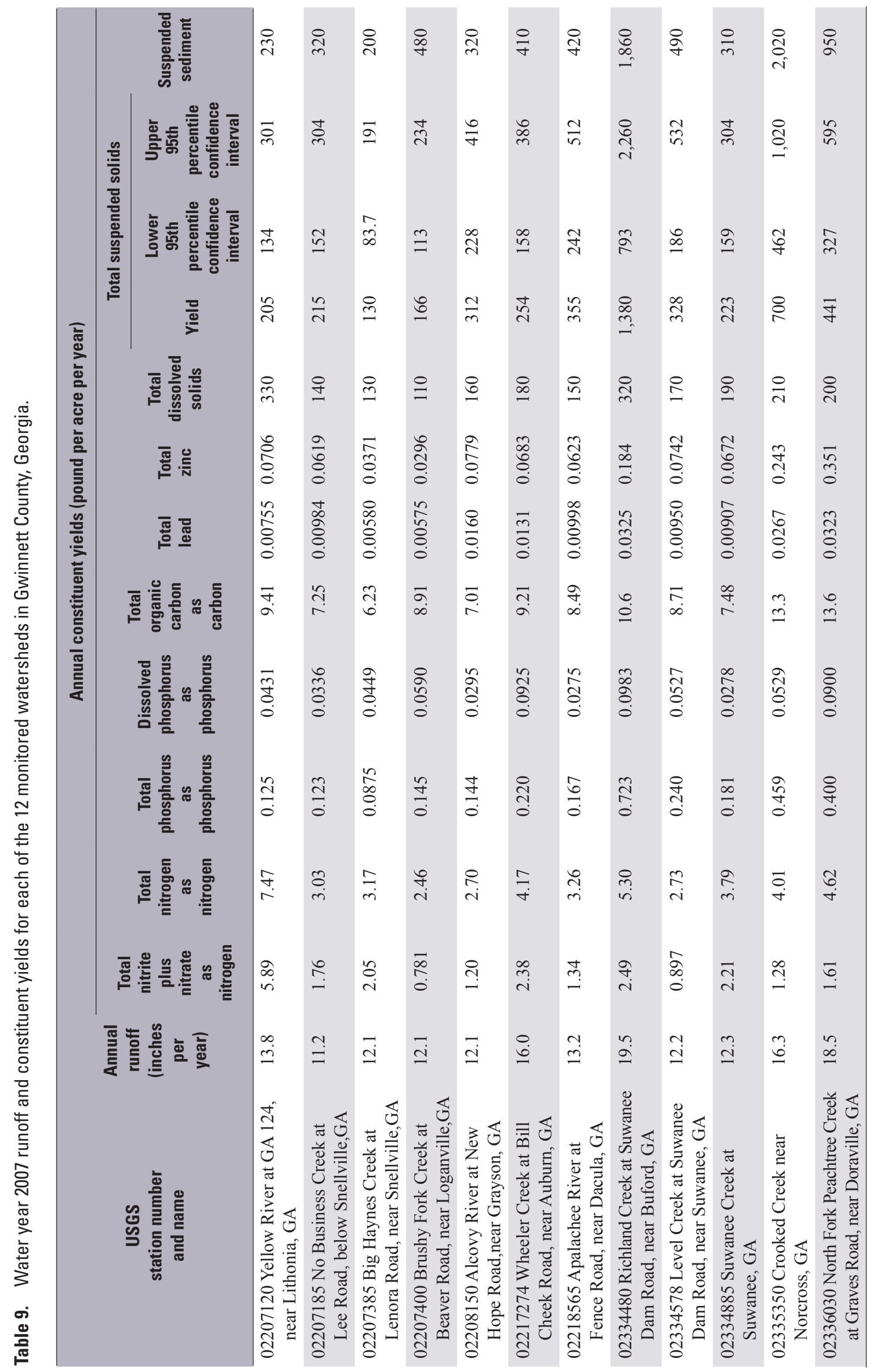




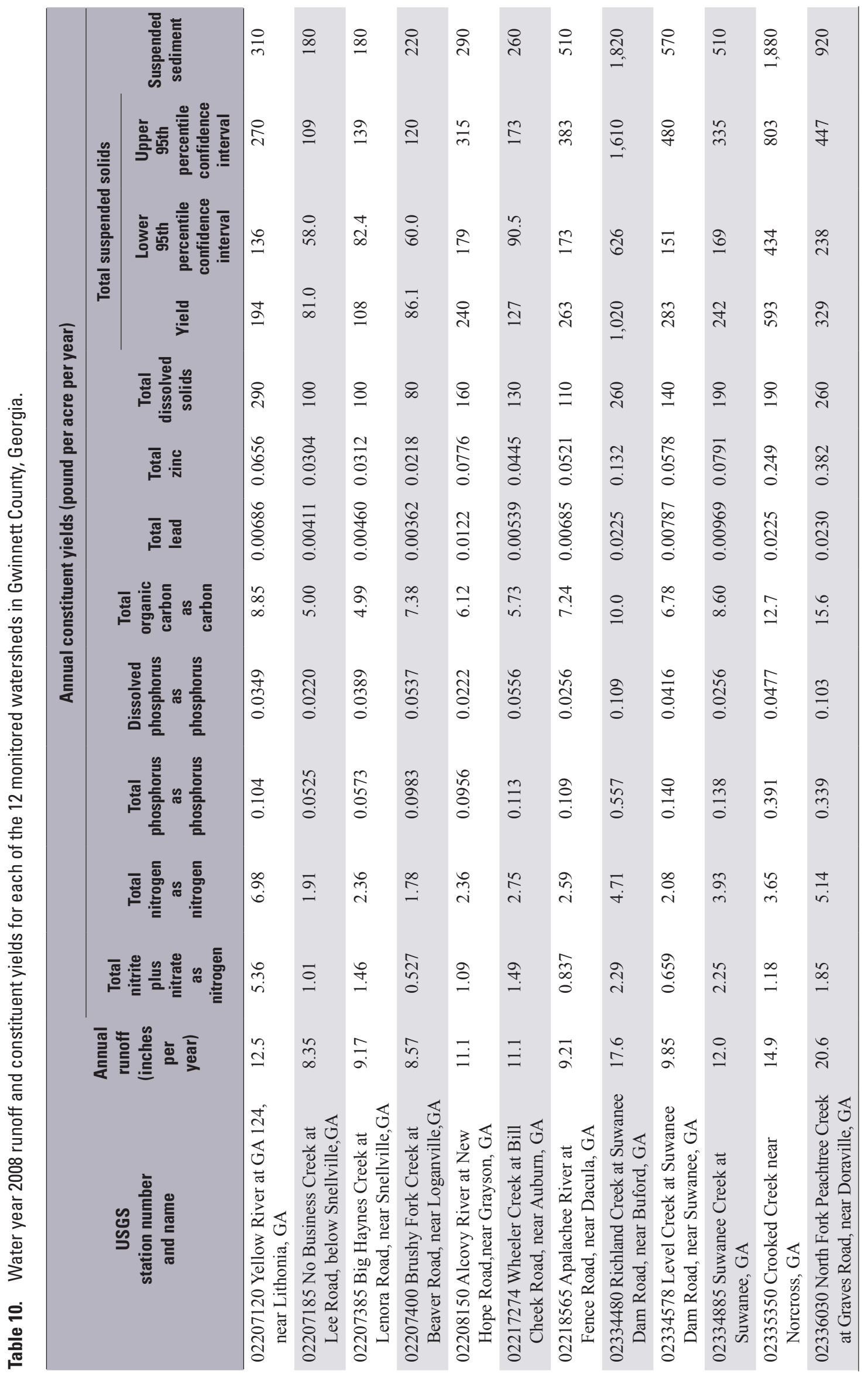




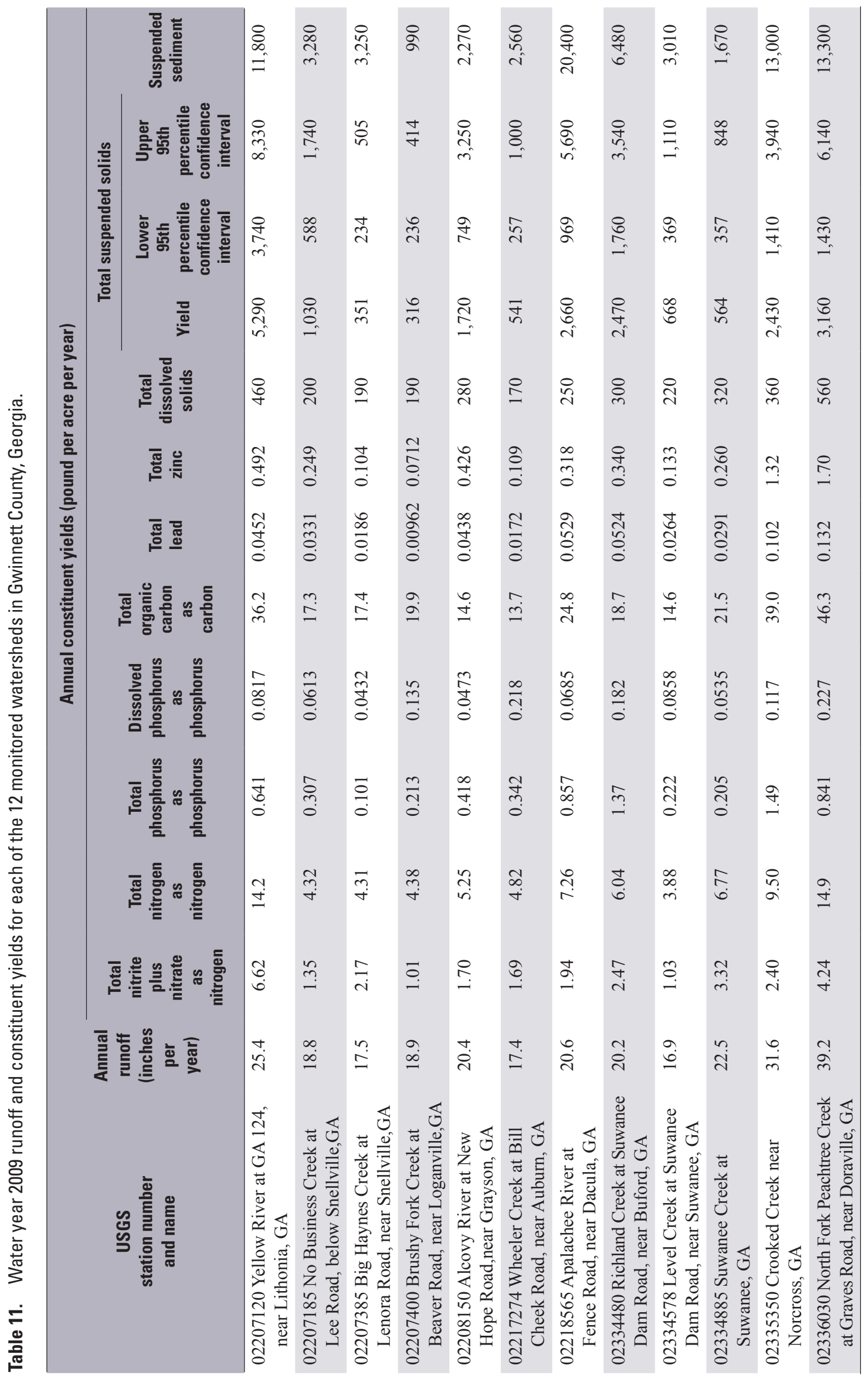




\section{Nutrients}

Average annual TN yields for 2004-09 were highest for Yellow River and North Fork Peachtree Creek watersheds (11.1 and 9.18 pounds per acre per year (lbs/acre/year) as $\mathrm{N}$, respectively; fig. 31) compared to TN yields for the 12 monitored watersheds. Yellow River also had the highest annual $\mathrm{NO}_{2}+\mathrm{NO}_{3}$ yields (6.93 lbs/acre/year as $\mathrm{N}$ ). Yellow River and North Fork Peachtree Creek have the third and first highest percentages of impervious area, respectively (table 3; fig. 9). Brushy Fork Creek, Alcovy River, and Level Creek watersheds had the three lowest average annual TN (4.47, 4.85 , and $4.83 \mathrm{lbs} /$ acre/year as $\mathrm{N}$, respectively) and $\mathrm{NO}_{2}+\mathrm{NO}_{3}$ (1.27, 1.84, and $1.41 \mathrm{lbs} /$ acre/year as $\mathrm{N}$, respectively) yields for 2004-09. None of these watersheds have high percentages of impervious areas, and Brushy Fork Creek and Level Creek watersheds have the fourth lowest and the lowest percentages of high-density development, 9.25 and 4.90 percent, respectively (table 3 ).
Nitrite plus nitrate loads make up about 57 percent of TN loads for the 12 watersheds combined for 2004-09 (fig. 30). Treated wastewater contributes much of the nitrogen load associated with base flow for Yellow River, Big Haynes Creek, and Suwanee Creek watersheds (Landers and others, 2007). These three watersheds had the highest, third highest, and fifth highest percentage of $\mathrm{NO}_{2}+\mathrm{NO}_{3}$ loads of $62.7,54.5$ and 49.8 percent, respectively, relative to TN loads.

Average annual TP yields for 2004-09 were highest for Richland Creek, Crooked Creek, and North Fork Peachtree Creek watersheds $(1.75,0.962$, and $0.855 \mathrm{lbs} /$ acre/year as $\mathrm{P}$, respectively; fig. 32) compared to TP yields for the 12 monitored watersheds. These three watersheds also had three of the highest four average annual TSS yields. Average annual DP yields for 2004-09 were highest for Wheeler Creek, Richland Creek, and North Fork Peachtree Creek watersheds (0.135, 0.117 , and $0.178 \mathrm{lbs} /$ acre/year as $\mathrm{P}$, respectively). These averages indicate that high TP and DP yields may be related even though DP makes up a small portion of TP. Richland

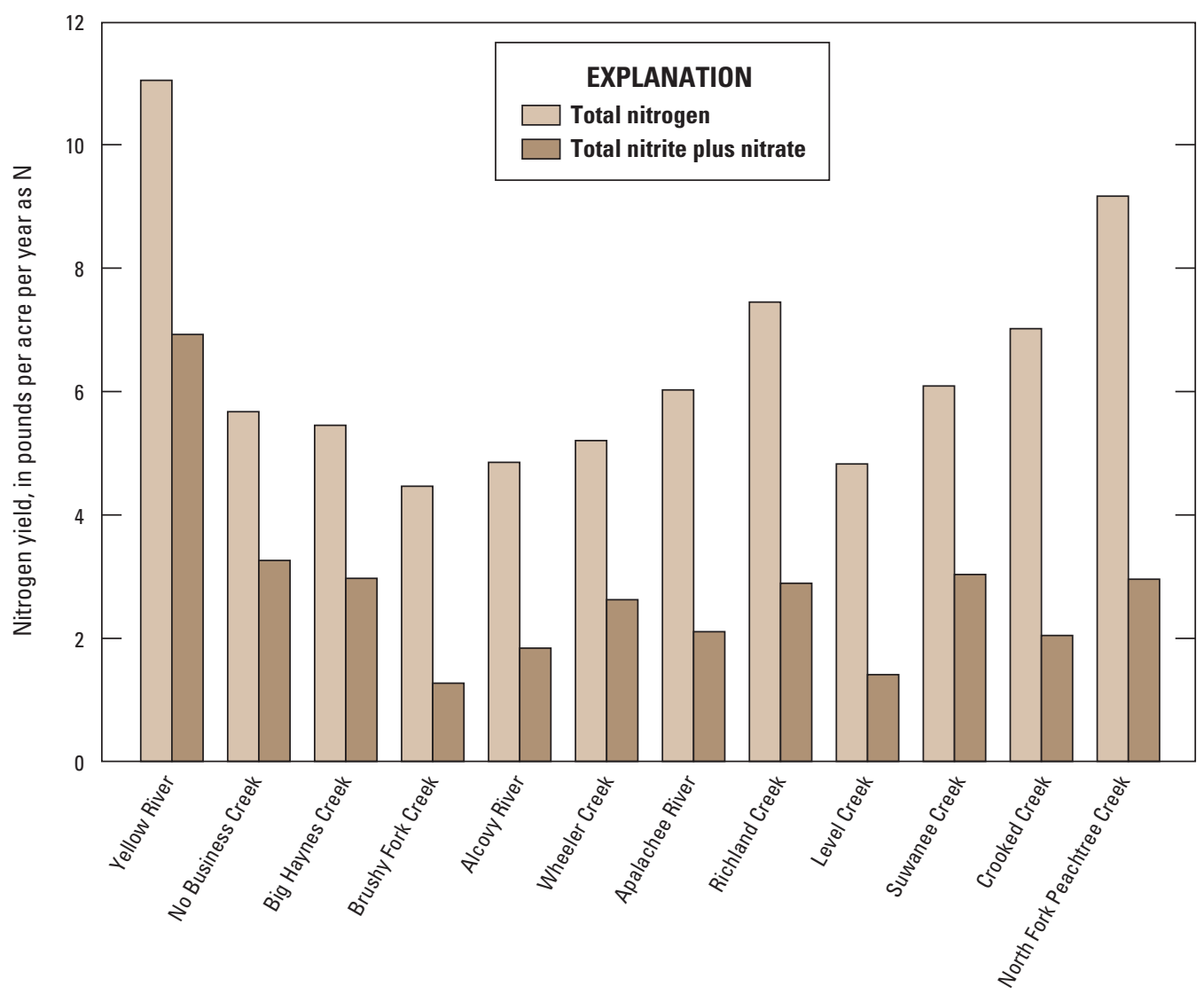

Monitored watersheds, Gwinnett County

Figure 31. Average annual total nitrogen and total nitrite plus nitrate yields for 12 monitored watersheds in Gwinnett County, Georgia, water years 2004-09. 


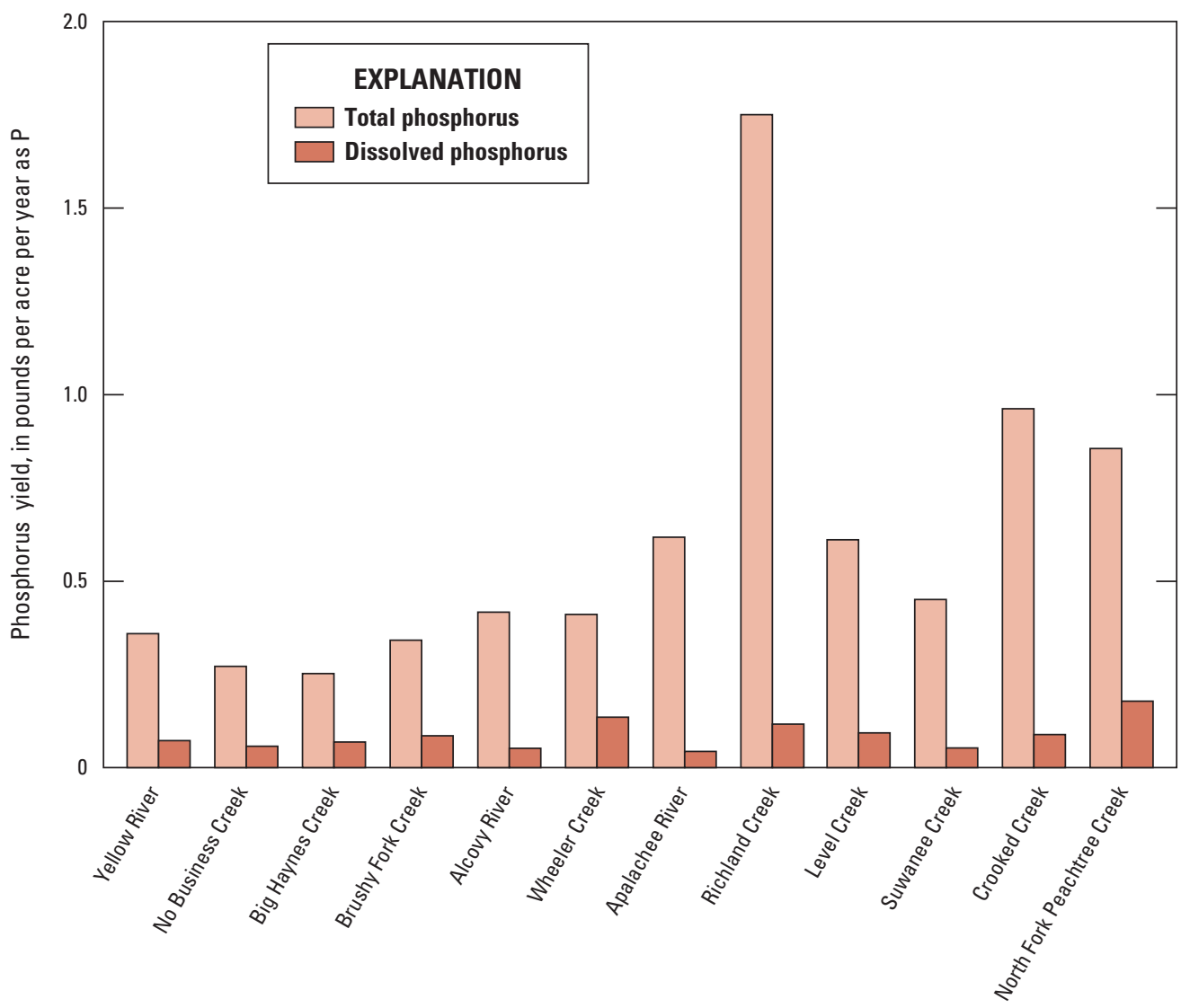

Monitored watersheds, Gwinnett County

Figure 32. Average annual total and dissolved phosphorus yields for 12 monitored watersheds in Gwinnett County, Georgia, water years 2004-09.

Creek watershed, which has the highest average annual TP yield and third highest average annual DP yield (fig. 32), has the highest basin slope of any of the 12 watersheds (fig. 5; table 3). Crooked Creek, which has the second highest average annual TP yield, and North Fork Peachtree Creek, which has the third highest average annual TP yield and highest average annual DP yield (fig. 32), have the two highest percentages of impervious area, 36.81 and 52.79, respectively (fig. 9; table 3). No Business Creek and Big Haynes Creek watersheds had the two lowest average annual TP yields for WYs 2004-09, 0.271 and $0.252 \mathrm{lbs} /$ acre/year as P, respectively (fig. 32). Big Haynes Creek watershed had the third lowest percentage of high-density development, 7.46 percent (table 3). Dissolved phosphorus loads make up about 16 percent of TP loads for the 12 watersheds combined for WYs 2004-09.

Average annual TOC yields for WYs 2004-09 are highest for Yellow River, Crooked Creek, and North Fork Peachtree Creek watersheds (20.1, 24.2 and $25.5 \mathrm{lbs} / \mathrm{acre} / \mathrm{year}$ as C, respectively; fig. 33) compared to TOC yields for the 12 monitored watersheds. These three watersheds have the three highest percentages of impervious area (table 3; fig. 9). Alcovy River watershed has the lowest average annual TOC yield for WY 2004-09, $13.2 \mathrm{lbs} /$ acre/year as C.

\section{Trace Elements}

Average annual $\mathrm{Pb}$ and $\mathrm{Zn}$ yields for water years 2004-09 were highest for Richland Creek, Crooked Creek, and North Fork Peachtree Creek watersheds (0.106, 0.061, and $0.078 \mathrm{lbs} / \mathrm{acre} /$ year $\mathrm{Pb}$, and $0.430,0.531$ and $0.769 \mathrm{lbs} / \mathrm{acre} /$ year $\mathrm{Zn}$, respectively, fig. 34) compared to $\mathrm{Pb}$ and $\mathrm{Zn}$ yields for the 12 monitored watersheds. These three watersheds also had three of the highest four average annual TSS yields. Richland Creek watershed has the highest basin slope of any of the 12 watersheds (fig. 5; table 3), whereas Crooked Creek and North Fork Peachtree Creek have the two highest percentages of impervious area (table 3; fig. 9). Big Haynes Creek and Brushy Fork Creek watershed had the two lowest average annual $\mathrm{Pb}$ and $\mathrm{Zn}$ yields for WYs 2004-09, 0.018 and $0.014 \mathrm{lbs} / \mathrm{acre} /$ year $\mathrm{Pb}$, and 0.083 and $0.059 \mathrm{lbs} /$ acre/year $\mathrm{Zn}$, respectively. These watersheds had the third and fourth lowest percentages of high-density development with 7.46 percent for Big Haynes Creek and 9.25 percent for Brushy Fork Creek (table 3). Average annual TSS yields were also low for these two watersheds. 
Figure 33. Average annual total organic carbon yields for 12 monitored watersheds in Gwinnett County, water years 2004-09.

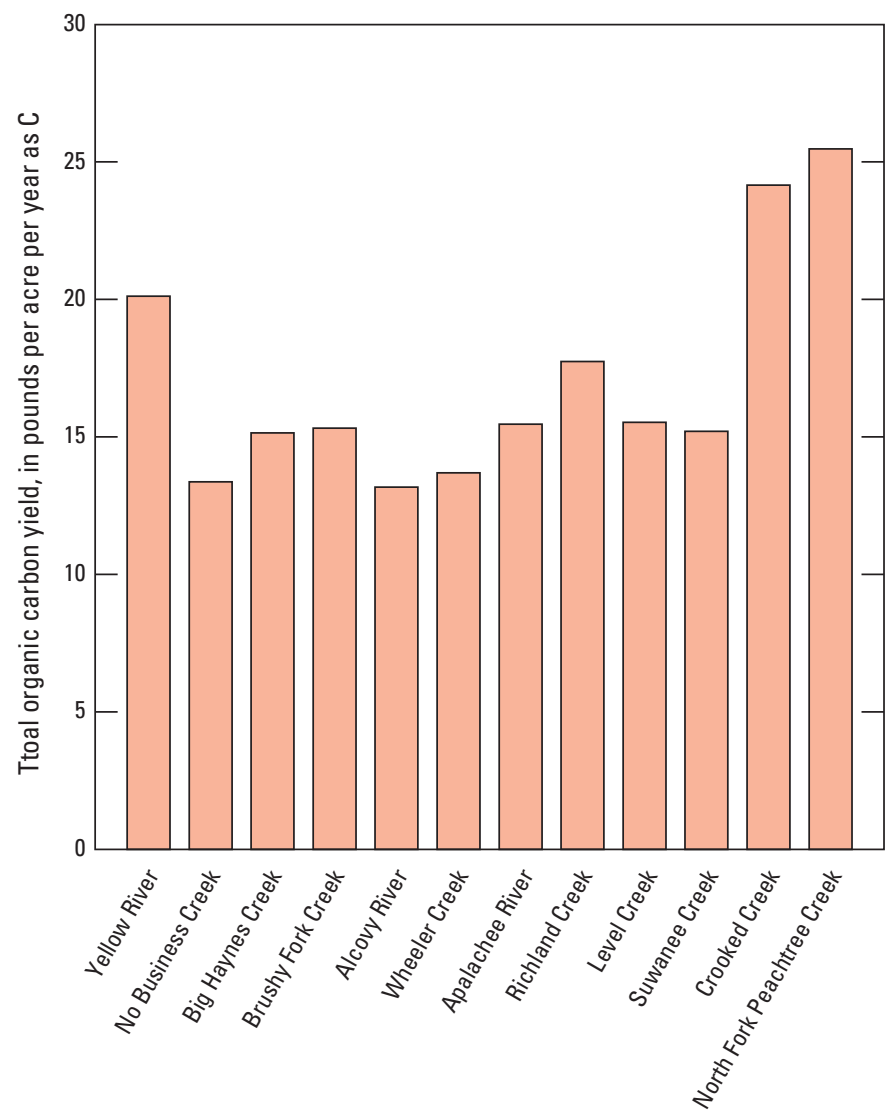

Monitored watersheds, Gwinnett County

Figure 34. Average annual total lead and zinc yields for 12 monitored watersheds in Gwinnett County, Georgia, water years 2004-09.

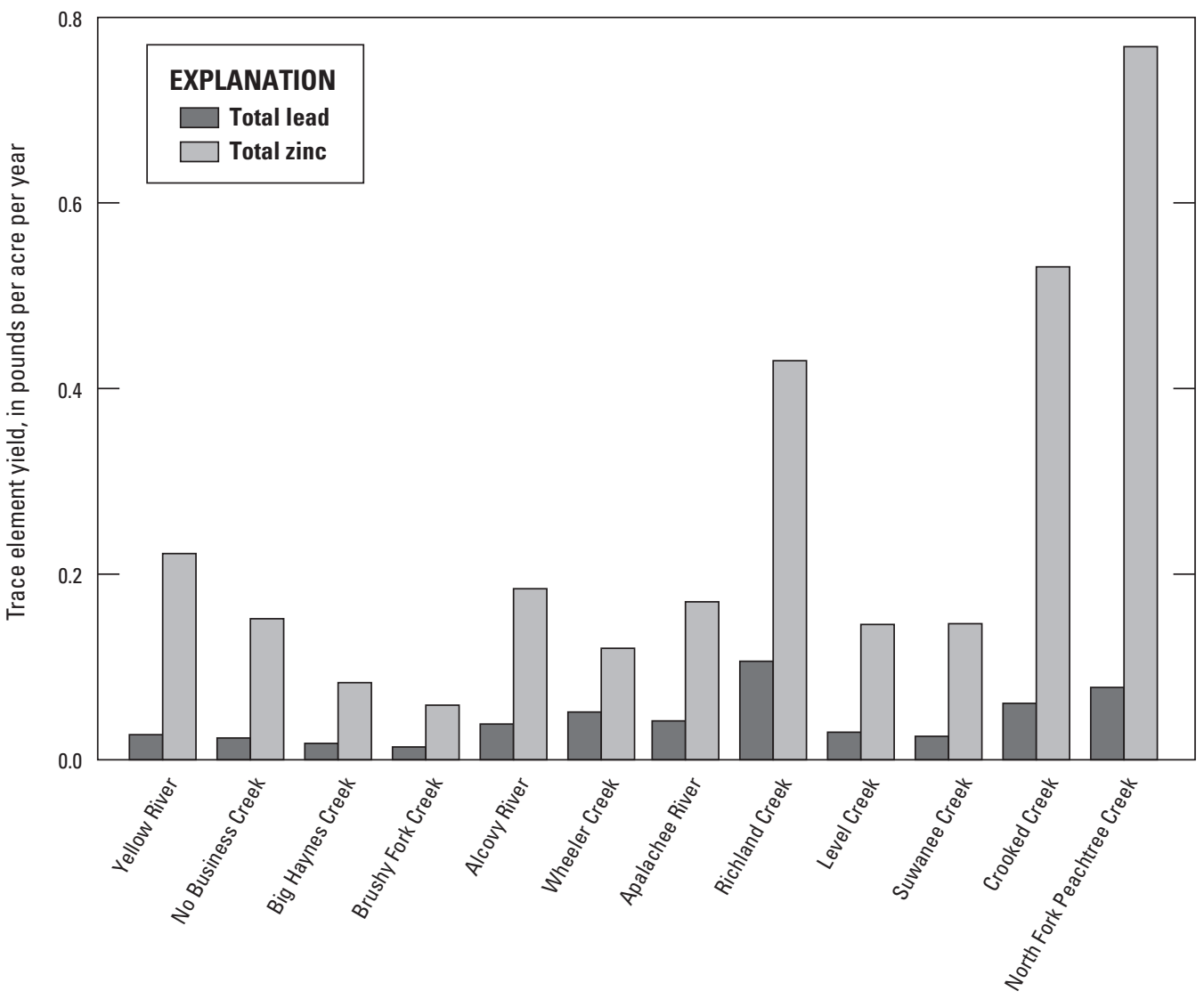

Monitored watersheds, Gwinnett County 


\section{Total Dissolved Solids}

Average annual TDS yields for WYs 2004-09 were highest for Yellow River and Richland Creek watersheds (425 and $413 \mathrm{lbs} /$ acre/year, respectively; fig. 35). Yellow River watershed had the third highest percentage of impervious area (fig. 9; table 3), whereas Richland Creek watershed had the highest basin slope of any of the 12 watersheds (fig. 5; table 3). Brushy Fork Creek watershed had the lowest average annual TDS yield for WYs 2004-09, $168 \mathrm{lbs} /$ acre/year, and had the fourth lowest percentage of high-density development, 9.25 percent (table 3 ).

\section{Suspended Sediment}

Total suspended solids and SSC typically increased by two orders of magnitude between base-flow and stormflow conditions (fig. 17L and 17M). One consequence of this dramatic increase in sediment concentration with discharge is that the majority of the annual load is transported during the few largest events of the year. A second consequence is that during drier years, very little sediment may be transported. For example, for the Alcovy River watershed, WYs 2004-05 and 2009 had average precipitation and runoff, whereas
WYs 2006-08 were very dry (fig. 36). Although runoff was about 46 percent lower in the drier years, WYs 2006-08, TSS yields were about 84 percent lower. There are fewer storms during drier years, and the storms tend to have low peak flows because base-flow discharges are also low, which then results in less sediment transported than might be expected on the basis of annual runoff alone.

Average annual TSS yields for WYs 2004-09 were highest for Yellow River, Apalachee River, Richland Creek, Crooked Creek, and North Fork Peachtree Creek watersheds $(1,420,1,370,2,940,1,560$, and $1,510 \mathrm{lbs} /$ acre/year, respectively; fig. 37). Richland Creek watershed, which had the highest average annual TSS yields, also had the highest basin slope of any of the 12 watersheds (fig. 5; table 3). Three of the other four watersheds, Yellow River, Crooked Creek, and North Fork Peachtree Creek had the three highest percentages of impervious area (fig. 9; table 3). Big Haynes Creek watershed had the lowest average annual TSS yield for WYs 2004-09, $401 \mathrm{lbs} /$ acre/year, and had the third lowest percentage of high-density development, 7.46 percent (table 3 ).

There is much variation in the annual TSS yields among the 12 watersheds because the ranks of watershed yield are not consistent from year to year. Richland Creek exhibited the highest annual yields of 6,590 lbs/acre in WY 2005 (table 7).
Figure 35. Average annual total dissolved solids yields for 12 monitored watersheds in Gwinnett County, Georgia, water years 2004-09.

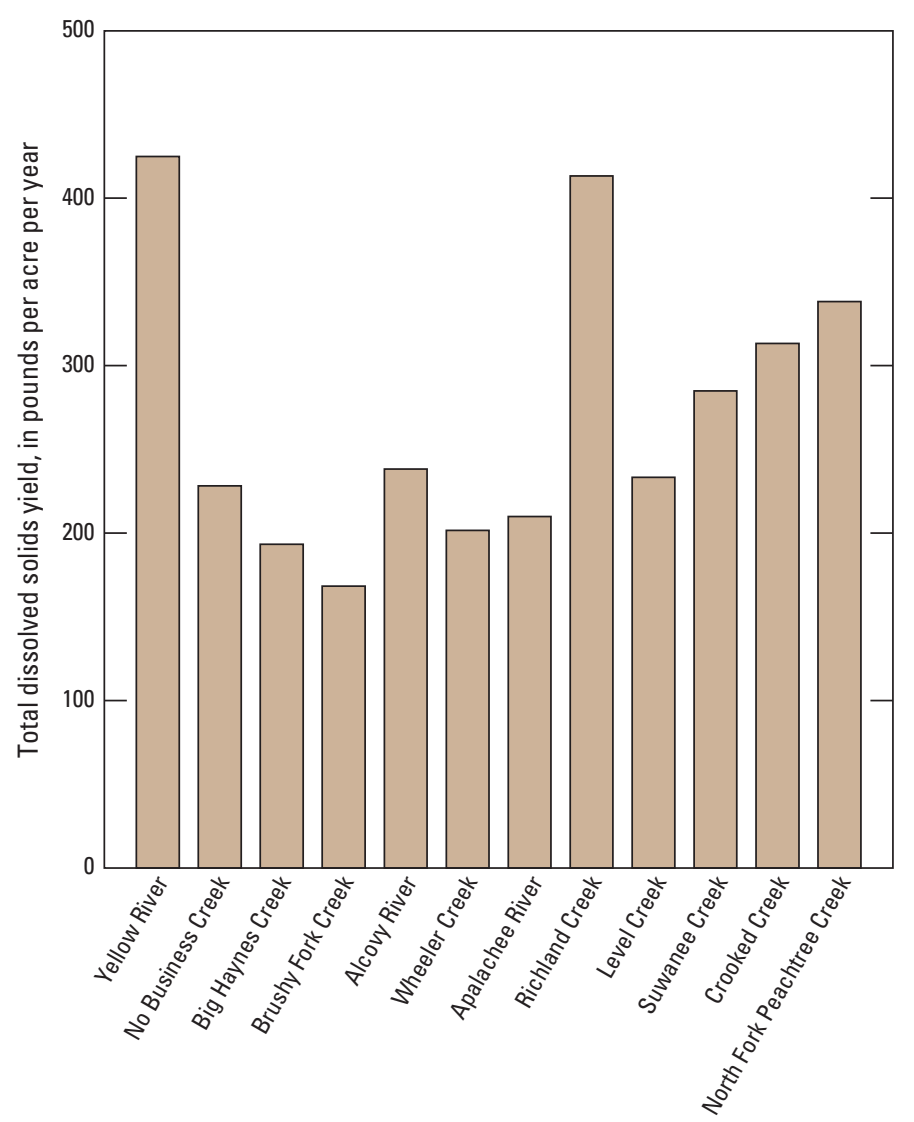

Monitored watersheds, Gwinnett County 


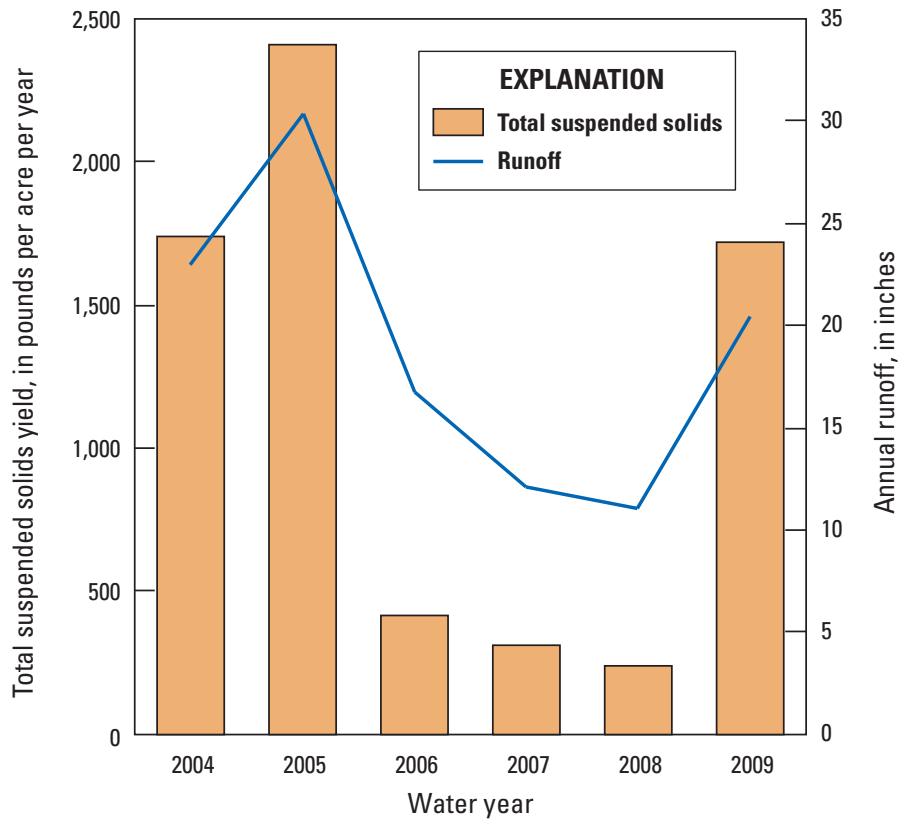

Figure 36. Annual total suspended solids yield and runoff at the Alcovy River, Gwinnett County, Georgia, water years 2004-09.

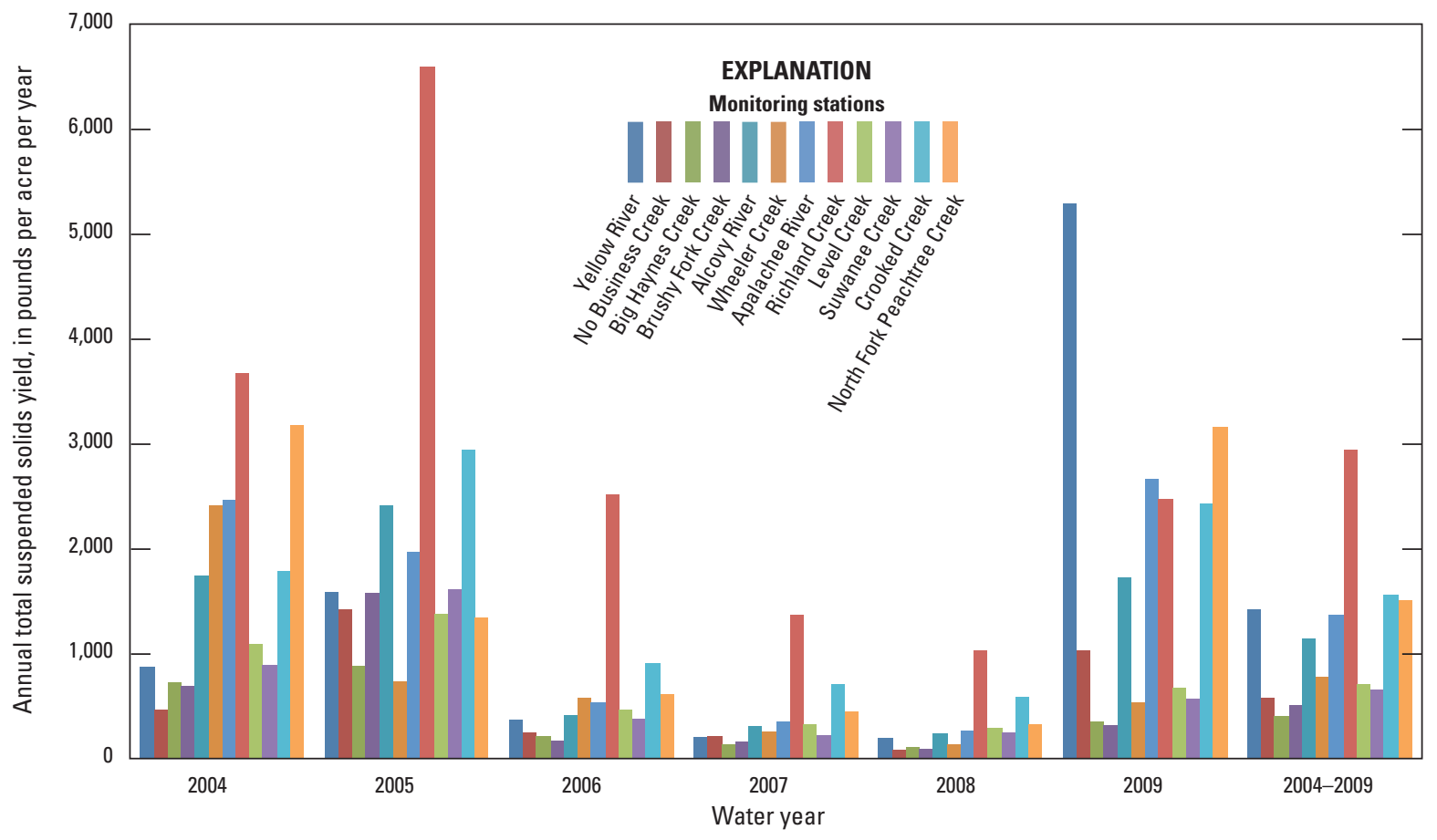

Figure 37. Average annual total suspended solids yields for 12 monitored watersheds in Gwinnett County, Georgia, water years 2004-09. 
These high yields may have been associated with construction of a large Gwinnett County park adjacent to Richland Creek during that timeframe. Gwinnett County experienced extreme flooding September 20-22, 2009, with the highest periodof-record discharges recorded at the Yellow River gage. The flood magnitude had an annual exceedance probability about equal to a 200-year flood (Gotvald and McCallum, 2010). A 200-year flood is defined as a flood that has a 1 in 200 chance (or 0.5 percent chance) of being equaled or exceeded in any one year (Holmes and Dinicola, 2010). Although the flood affected the entire county, the Yellow River watershed was particularly affected by the flood, which resulted in the Yellow River having the highest WY 2009 TSS yields of $5,290 \mathrm{lbs} /$ acre (table 11). It is not unusual for a few of the largest storms in a year to transport the majority of the annual sediment load and is the result of the nearly two orders of magnitude increase in sediment concentrations between base flow and average stormflow observed at the 12 watersheds (fig. $17 \mathrm{~L}$ and $17 \mathrm{M}$ ). Annual sediment yields are, therefore, sensitive to the occurrence and magnitude of the largest storms, and this may help explain the large variability in annual yields observed among the watersheds.

Average annual SSC tells a somewhat different story for sediment than TSS. Although the watersheds with the highest TSS yields also had the highest SSC yields, SSC yields were significantly higher than TSS yields (fig. 38). For WYs 2004-09, the ratio of SSC to TSS loads for all watersheds combined was about 1.9, but this ratio varied widely by watershed: Alcovy River had the lowest ratio of 1.0, and Brushy Fork Creek and Apalachee River had the highest ratios of 4.8 and 3.7, respectively. The watersheds with higher TSS and SSC yields generally had higher SSC to TSS ratios. Presumably, watersheds that have a higher percentage of sand tend to have a greater discrepancy between SSC and TSS (fig. 18). Despite the differences between SSC and TSS, annual yields of TSS are used as the primary performance criterion for suspended sediment in the Gwinnett County Watershed Protection Plan (Gwinnett County Department of Public Utilities, 2000).

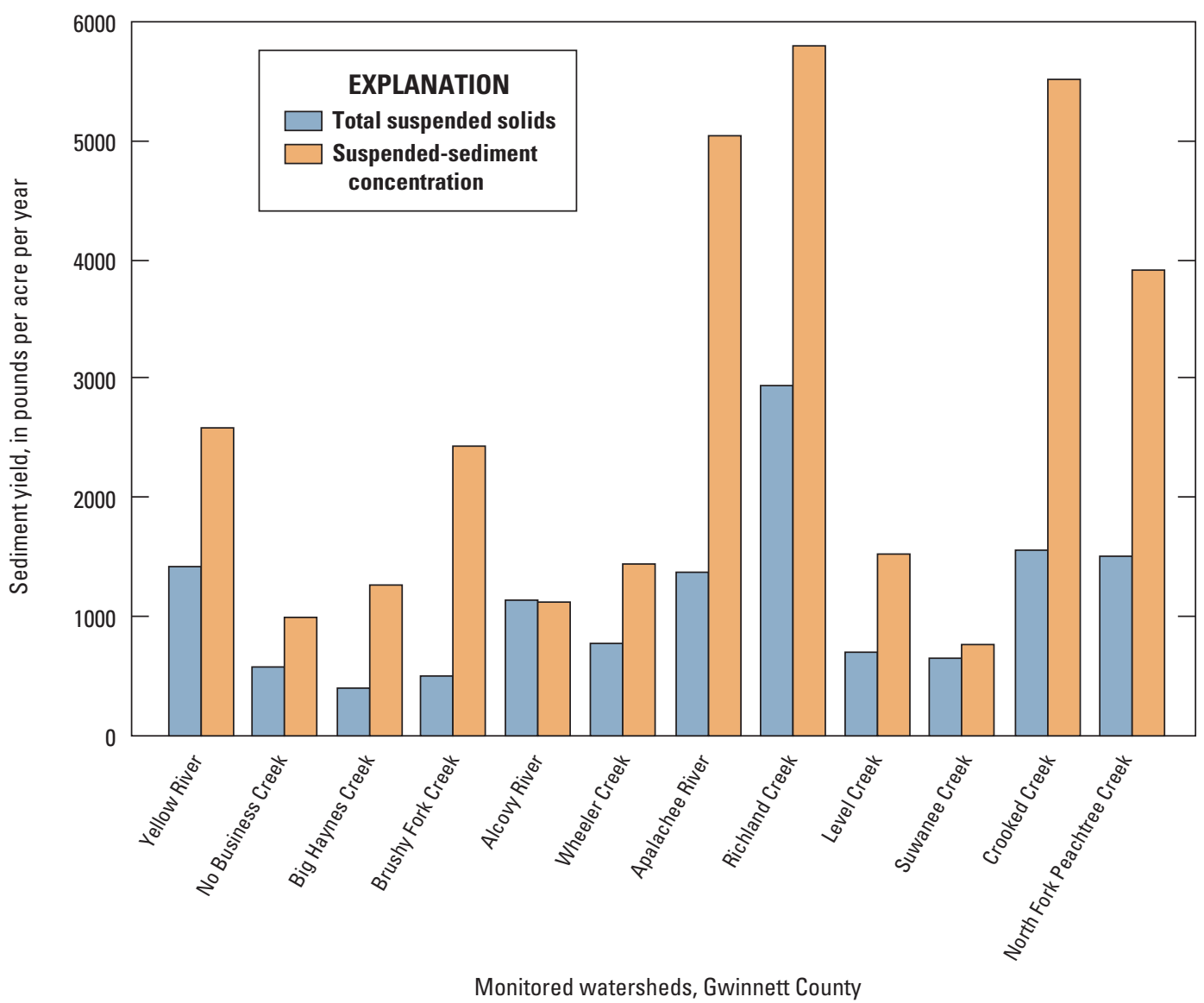

Figure 38. Average annual total suspended solids and suspended-sediment concentration yields for 12 monitored watersheds in Gwinnett County, Georgia, water years 2004-09. 


\section{Interpreting Aggregate Effects on Water Quality}

The water quality of streams in a watershed reflects and integrates the effects of watershed characteristics, hydrologic processes and variability, biogeochemical processes, and human influences. Changes in land use alter complex interactions that affect many processes within a watershed (MacDonald, 2000).

Although varying watershed characteristics and land use can indicate possible explanations for variations in water quality among the watersheds; relations rarely reflect straightforward cause and effect. There may be specific, unaccounted human activities present within individual watersheds that result in point-source pollutants that affect water-quality constituents. Several factors can result in similar water-quality patterns; for example, high impervious area and steep basin slope both appear to be related to greater transport and higher yields of TSS and SSC in this study. A specific watershed characteristic may not always relate to a particular waterquality pattern in all cases because water quality is integrating all the processes within the watershed; for example, in this study the watersheds with the lowest $\mathrm{Zn}$ yields also had low percentages of high-density development, yet watersheds with low percentages of high-density development do not all have low $\mathrm{Zn}$ yields. Many watershed characteristics are also related to each other, whereas individual characteristics may be better at explaining particular relations in water quality. For example, the percentage area of high-density development and impervious area are correlated with each other, but high-density development may be better related to specific trace elements that might be the result of pollutants, while impervious area may be more related to the transport of TSS and SCC. Furthermore, Gwinnett County has long required BMPs to control and mitigate the effects of increases in impervious areas. The effectiveness of these measures to counteract the effects of impervious areas is difficult to assess because the two variables are correlated with each other: more BMPs are implemented in watersheds that have higher percentages of impervious area.

The effects of variations in climate can have large effects on water-quality concentrations, loads, and yields. These effects occur for any water-quality constituent that exhibits concentration variations with discharge or season, as variations in the amount and distribution of runoff annually and seasonally will affect the concentrations observed along with the flow-weight for estimating load. This is especially notable for constituents that are transported during storms that exhibit a strong relation of increasing concentration with discharge, such as sediment (TSS and SSC) and other sediment related constituents (TP, $\mathrm{Zn}$, and $\mathrm{Pb}$ ). Dry years have less runoff (lower average annual discharges) with generally smaller storm hydrologic responses (due to reduced base flow), which result in less opportunity for storm transport. Similarly, wet years have more runoff and greater storm hydrologic response, resulting in more transport. For constituents that exhibit increasing concentrations with discharge, dry years will have lower annual average concentrations whereas wet years will have higher annual average concentrations. For constituents that exhibit dilution at higher discharge, annual average concentrations will be higher in dry years and lower in wet years. While the amount of annual runoff is often the most important controlling factor determining the magnitude of annual loads, variations in concentrations related to variations in discharge may also have an important effect, as observed for TSS yields at the Alcovy River (fig. 36). Although runoff was about 46 percent lower in the drier years, WYs 2006-08, TSS yields were about 84 percent lower, due to the effects of lower TSS concentrations at lower discharges.

\section{Summary}

The U.S. Geological Survey (USGS), in cooperation with Gwinnett County Department of Water Resources, established a comprehensive Long-Term Trend Monitoring (LTTM) program in 1996 to monitor, analyze, and quantify the magnitudes of pollutants and the effects of urbanization on six watersheds. In 2001, six additional watersheds were added to the LTTM program. These 12 watersheds were continuously monitored for water level (stage), discharge, precipitation, and water-quality properties (water temperature, specific conductance [SC], and turbidity) for water years (WYs) 2004-09. For each season, summer (May-October) and winter (November-April), three storm-composited samples were collected during storm events and one sample was collected during base-flow conditions for a total of eight samples per year; samples were analyzed for SC, turbidity, nutrients (nitrite plus nitrate $\left[\mathrm{NO}_{2}+\mathrm{NO}_{3}\right]$, total ammonia plus organic nitrogen [TKN], total phosphorus [TP], dissolved phosphorus [DP], and total organic carbon [TOC]), total dissolved solids (TDS), trace metals (total lead [Pb] and total zinc [Zn]), and suspended sediment (total suspended solids [TSS] and suspended-sediment concentration [SSC]). The sampling scheme was designed to identify variations in water quality both hydrologically and seasonally.

Gwinnett County, a suburban county of the Atlanta metropolitan area, is composed predominantly of headwater watersheds along the Eastern Continental Divide. Watershed basin slopes range from 5.3 to 13.8 percent. Gwinnett County has undergone rapid population growth from about 1980 to 2010 , though growth has slowed somewhat during the latter part of the study period, 2004-09. Land use has become more highly developed over time. Land use is summarized for each watershed for 2009. The percentage of impervious area has a large influence on hydrology and water quality. Changes in the percentage of impervious area are documented for 2000-2009, with increases of varying extent observed within most watersheds. 
Gwinnett County has a humid, subtropical climate with a mean annual precipitation of 54.7 inches, and high evapotranspiration rates during the growing season. Precipitation in WYs 2004-09 was about 18 percent below average, and the county experienced exceptional drought conditions in WYs 2007 and 2008. Low precipitation resulted in below average runoff. Watershed water yields, the percentage of precipitation that occurs as runoff, ranged from 34.3 to 59.4 percent for WYs 2004-09; water yields typically are lower in low precipitation years. The watersheds with the highest percentage of impervious areas have the highest water yields.

A comparison of base-flow and stormflow water quality indicate that turbidity, TKN, TN, TP, TOC, Pb, Zn, TSS, and SSC concentrations increased with increasing discharge at all watersheds, yet SC decreased during stormflow at all watersheds and TDS exhibited dilution at a few of the watersheds. Total suspended solids and SSC concentrations typically were two orders of magnitude higher in stormflow samples, turbidities were about 1.5 orders of magnitude higher, TP and $\mathrm{Zn}$ were about one order of magnitude higher, and TKN, TN, $\mathrm{TOC}$, and $\mathrm{Pb}$ were about twofold higher.

Seasonal patterns in TN, TP, TDS, TSS, and Zn were all fairly similar, with higher concentrations in the summer and lower in the winter. A linear long-term trend analysis for stormflow composite concentrations of TN, TP, TDS, TSS, and $\mathrm{Zn}$ identified significant trends in 36 of the 60 constituent-watershed combinations. When a watershed did have a significant trend, the trends typically were decreasing for TN (4 decreasing, 1 increasing), TP (11 decreasing), TSS ( 7 decreasing, 1 increasing), and $\mathrm{Zn}$ (4 decreasing) and typically were increasing for TDS (7 increasing, 1 decreasing). Total nitrogen, TP, and Zn changes in concentrations over time were small. Total dissolved solids and TSS trends were larger. Despite the strong relation between TSS yields and the percentage of watershed impervious area, trends in TSS concentrations did not always correlate with the observed changes in impervious areas. No linear trends were detected in annual runoff for any of the 12 watersheds that could have produced trends in TSS concentrations. But suspendedsediment concentrations and transport are controlled particularly by the magnitude of storm runoff, rather than the amount of annual runoff. Trends in the variations of the magnitude of storm runoff were not assessed. The cause of trends in TSS has not been attributed, but is likely the result of a combination of climatic patterns (resulting in variability of magnitude, intensity, and duration of storms), changes in impervious areas, and the continued implementation of best management practices (BMPs) (such as stormwater detention ponds, diversion structures, and stream buffers) and other erosion controls used to minimize sediment transport.

Stream water constituent loads were estimated for 10 water-quality constituents. These estimates represent the cumulative effects of watershed characteristics, hydrologic processes and variability, biogeochemical processes, and human influences on watershed water quality. Yields, in load per unit area, were used to compare loads from watersheds with different sizes. For the Gwinnett County LTTM program, storm samples were collected as a composite so the load estimation approach developed and used for the Gwinnett County LTTM program for 1998-2003 (Landers and others, 2007) was used with some minor modifications. This approach employs the commonly used regression-model method, but develops separate relations for base-flow and storm-based average concentrations. Concentrations were modeled as a function of discharge, time, season, and turbidity to improve model predictions and reduce errors in load estimates.

The amount of annual runoff is the primary factor in determining the amount of annual constituent loads. Below average precipitation during the WYs 2004-09 study period, and especially during WYs $2006-08$, resulted in corresponding below average runoff and loads. Variations in constituent yields between watersheds appeared to be related to various watershed characteristics. Suspended sediment (TSS and SSC) along with constituents transported predominately in solid phase (TP, TOC, Pb, and Zn), and TDS typically had higher yields from watersheds that had high percentages of impervious areas (Yellow River, Crooked Creek, and North Fork Peachtree Creek) or high basin slope (Richland Creek). High TN yields were also associated with watersheds with high percentages of impervious areas. Higher percentages of impervious area result in increases of runoff over infiltration, flood magnitudes, and the "flashiness" of flooding, which can result in increased land-surface erosion and stream transport of sediments.

Watersheds with higher percentages of $\mathrm{NO}_{2}+\mathrm{NO}_{3}$ loads relative to TN loads were frequently associated with watersheds where treated wastewater was known to contribute much of the nitrogen load associated with base flow. Low TN, TSS, $\mathrm{Pb}$, and $\mathrm{Zn}$ yields appear to be associated with watersheds that have a low percentage of high-density development, but this characteristic did not preclude having higher yields. Watersheds with either high or low $\mathrm{Pb}$ and $\mathrm{Zn}$ yields typically also had high or low TSS yields, respectively.

Annual patterns in TSS yields between watersheds were quite variable. TSS yields were lower in drought years, WYs 2007 and 2008, from the combined effects of lower runoff and fewer, lower magnitude storms, which likely resulted in less surface erosion and lower stream sediment transport during the drought. Suspended-sediment transport is particularly sensitive to storms, as evident from the two orders of magnitude increase in concentration observed between base-flow and storm-event samples. Total suspended solids and SSC yields differed, which is possibly the result of low-biased TSS concentrations for samples with sand fractions of greater than 25 percent.

Interpreting the aggregate effects of watershed characteristics, hydrologic processes and variability, biogeochemical processes, and human influences on watershed water quality is complex. Although some factors, such as impervious area, may relate to a pattern observed in water-quality yields, other factors, both measured and unmeasured, can obscure this relation. Some factors may be correlated with each other, which 
may make it difficult to determine what specifically might be the cause of a particular water-quality relation. For example, the effectiveness of the implementation of BMPs to counteract the effects of impervious areas is difficult to assess because BMPs are correlated with impervious area: more BMPs are implemented in watersheds that have higher percentages of impervious area. In this case, more BMPs have a positive effect on water quality, yet higher impervious area has a negative effect. Patterns and trends in climate also affect water quality. Despite the exceptional drought observed, no linear trends in runoff were detected for any of the 12 watersheds. This study did not determine whether there were any patterns or trends in the frequency, magnitude, or duration of storm events, which could also affect the results.

Long-term, comprehensive records of climatic, hydrologic, and water-quality conditions can be used by watershed managers to evaluate, protect, and enhance the rivers and streams. The monitoring stations used in this study represent a range of watershed conditions, including water-quality attainment status, point-source discharges, and other physical characteristics. The computation and analysis of constituent loads is a critical element and useful tool in the management and protection of the diverse watersheds in Gwinnett County, Georgia. Total suspended solids annual loads have been identified in the Gwinnett County Watershed Protection Plan for target performance criterion. The Gwinnett County Department of Water Resources uses these computations along with the assessment of trends in imperviousness for the management and protection of aquatic habitat. Real-time data and additional USGS tools, such as WaterAlert, are valuable assets available to the public and the managers of Gwinnett County for flood warning and emergency management and for the identification of potential pollution issues.

\section{Acknowledgments}

This report is possible because of the field data-collection efforts and analysis expertise of the U.S. Geological Survey, Gwinnett Project personnel: Paul Ankcorn, Kerry Caslow, Jonathan Evans, Brandon Reyes, and Karen Stull. Thanks are extended to Susan Grams and Edward Martin of the U.S. Geological Survey for assisting in the modeling and computing of constituent loads. Thanks are also extended to U.S. Geological Survey employees Jamie Painter for GIS support, Caryl Wipperfurth and Kimberly Swidarski for preparations of illustrations, and Kay Naugle for editing the report.

\section{References Cited}

ASTM International, 2003, ASTM D1889-00, Standard test method for turbidity of water: West Conshohocken, Pennsylvania, ASTM International, Annual Book of ASTM Standards, Water and Environmental Technology, v. 11.01, 6 p.

Atlanta Regional Commission, 2010, 2009 Land use GIS dataset, accessed 2013, at http://www.atlantaregional.com/ info-center/gis-data-maps/gis-data.

Aulenbach, B.T., 2013, Improving regression-model-based streamwater constituent load estimates derived from serially correlated data: Journal of Hydrology, v. 203, p. 55-66.

Bornstein, R., and Lin, Q., 2000, Urban heat islands and summertime convective thunderstorms in Atlanta-Three case studies: Atmospheric Environment, v. 34, p. 507-516.

Cleveland, W.S., 1979, Robust locally weighted regression and smoothing scatterplots: Journal of the American Statistical Association, v. 74, p. 829-836.

Cohn, T.A., Caulder, D.L., Gilroy, E.J., Zynjuk, L.D., and Summers, R.M., 1992, The validity of a simple statistical model for estimating fluvial constituent loads - An empirical study involving nutrient loads entering Chesapeake Bay: Water Resources Research, v. 28, no. 9, p. 2353-2363.

Cohn, T.A., DeLong, L.L., Gilroy, E.J., Hirsch, R.M., and Wells, D.K., 1989, Estimating constituent loads: Water Resources Research, v. 25, no. 5, p. 937-942.

Crawford, C.G., 1991, Estimation of suspended-sediment rating curves and mean suspended-sediment loads: Journal of Hydrology, v. 129, p. 331-348.

Dann, M.S., Lynch, J.A., and Corbett, E.S., 1986, Comparison of methods for estimating sulfate export from a forested watershed: Journal of Environmental Quality, v. 15, no. 2, p. 140-145.

Ferguson, R.I., 1986, River loads underestimated by rating curves: Water Resources Research: v. 22, no. 1, p. 74-76.

Gotvald, A.J., 2010, Surface-water quality-assurance plan for the U.S. Geological Survey Georgia Water Science Center: U.S. Geological Survey Open-File Report 2010-1263, 43 p.

Gotvald, A.J., and McCallum, B.E., 2010, Epic flooding in Georgia, 2009: U.S. Geological Survey Fact Sheet 2010-3107, 2 p.

Gwinnett County Department of Public Utilities, 2000, Gwinnett County Watershed Protection Plan: Atlanta, Ga., CH2MHill, p. 4-6. (Also available at http://www. gwinnettcounty.com/static/departments/publicutilities/pdf/ Gwinnett-WPP.pdf.) 
Gwinnett County, Georgia, 2004, State of the County 04 Gwinnett County, 4 p., accessed January 2014, at http://www.gwinnettcounty.com/static/departments/boc/ pdf/2004_state_county.pdf.

Gwinnett County, Georgia, 2005, State of the County 05 Gwinnett County, 4 p., accessed January 2014, at http://www.gwinnettcounty.com/static/departments/boc/ pdf/2005_state_county.pdf.

Gwinnett County, Georgia, 2006, State of the County 06 Gwinnett County, 4 p., accessed January 2014, at http://www.gwinnettcounty.com/static/departments/boc/ pdf/2006_SOC.pdf.

Gwinnett County, Georgia, 2007, 07 State of the County, 4 p., accessed January 2014, at http://www.gwinnettcounty.com/ static/departments/boc/pdf/2007_state_of_the_county.pdf.

Gwinnett County, Georgia, 2008, 08 State of the County, 4 p., accessed January 2014, at http://www.gwinnettcounty.com/ static/departments/boc/pdf/2008_SOC_handout.pdf.

Gwinnett County, Georgia, 2009, Gwinnett County State of the County, January 2009, 4 p., accessed January 2014, at http://www.gwinnettcounty.com/static/departments/boc/ pdf/09_SOC_Handout.pdf.

Gwinnett County, Georgia, 2010, Gwinnett County State of the County, February 2010, 2 p., accessed January 2014, at http://www.gwinnettcounty.com/static/departments/boc/ pdf/2010_SOC_Handout.pdf.

Gwinnett County, Georgia, 2012, State of the County, February 2012, accessed January 2014, 2 p., at http://www.gwinnettcounty.com/static/pdf/2012_SOC_ Handout.pdf.

Gwinnett County, Georgia, 2013, State of the County January 2013, accessed January 2014, 2 p., at http://www.gwinnettcounty.com/static/departments/boc/ pdf/2013_SOC_Handout_FINAL.PDF.

Gwinnett County, Georgia, 2014, State of the County, January 2014, accessed January 2014, 2 p., at http://www.gwinnettcounty.com/static/departments/boc/ pdf/2014_SOC_Handout.pdf.

Hardy, M.A., Parliman, D.J., and O'Dell, Ivalou., 2005, Status of and changes in water quality monitored for the Idaho statewide surface-water-quality network, 1989-2002: U.S. Geological Survey Scientific Investigations Report 2005-5033, 66 p., 3 apps.

Hirsch, R.M., Alexander, R.B., and Smith, R.A., 1991, Selection of methods for the detection and estimation of trends in water quality: Water Resources Research, v. 27, no. 5, p. $803-813$.
Hollis, G.E., 1975, The effect of urbanization on floods of different recurrence interval: Water Resources Research, v. 11, no. 3 , p. $431-435$.

Holmes, R.R., Jr., and Dinicola, K., 2010, 100-year flood-It's all about chance, Haven't we already had one this century?: U.S. Geological Survey General Information Product 106, $4 \mathrm{p}$.

Horowitz, A.J., 2003, An evaluation of sediment rating curves for estimating suspended sediment concentrations for subsequent flux calculations: Hydrological Processes, v. 17. p. 3387-3409.

Johnson, A.H., 1979, Estimating solute transport in streams from grab samples: Water Resources Research, v. 15, no. 5, p. 1224-1228.

Landers, M.N., 2013, Total suspended solids concentrations and yields for water-quality monitoring stations in Gwinnett County, Georgia, 1996-2009: U.S. Geological Survey Open-File Report 2013-1145, 10 p., accessed July 21, 2014, at $h t t p: / / p u b s . u s g s . g o v / o f / 2013 / 1145 /$.

Landers, M.N., Ankcorn, P.D., and McFadden, K.W., 2007, Watershed effects on streamflow quantity and quality in six watersheds of Gwinnett County, Georgia: U.S. Geological Survey Scientific Investigations Report 2007-5132, 62 p.

Larson, S.J., Capel, P.D., Goolsby, D.A., Zaugg, S.D., and Sandstrom, M.W., 1995, Relations between pesticide use and riverine flux in the Mississippi River basin: Chemosphere, v. 31, no. 5, p. 3305-3321.

Leopold, L.B., 1968, Hydrology for urban land planning-A guidebook on the hydrologic effects of land use: U.S. Geological Survey Circular 554, 18 p.

Likens, G.E., Bormann, F.H., Pierce, R.S., Eaton, J.S., and Johnson, N.M., 1977, Biogeochemistry of a forested ecosystem: New York, Springer-Verlag, 146 p.

MacDonald, L.H., 2000, Evaluating and managing cumulative effects-Process and constraints: Environmental Management, v. 26, no. 3, p. 299-315.

McCrary, M., 2011, Effects of topography on North Georgia (Atlanta, GA) severe weather and tornadoes, accessed July 12, 2011, at http://www.theweatherprediction.com/ weatherpapers/122/index.html.

National Oceanic and Atmospheric Administration, National Climatic Data Center, 2014, 1981-2010 U.S. climate normals, accessed May 1, 2014, at http://www.ncdc.noaa.gov/ oa/ncdc.html. 
Ogden, F.L., Pradhan, N.R., Downer, C.W., and Zahner, J.A., 2011, Relative importance of impervious area, drainage density, width function, and subsurface storm drainage on flood runoff from an urbanized catchment: Water Resources Research, v. 47, W12503, 12 p.

Preston, S.E., Bierman, V.J., Jr., and Silliman, S.E., 1989, An evaluation of methods for the estimation of tributary mass loads: Water Resources Research, v. 25, no. 10, p. 1379-1389.

Rantz, S.E., and others, 1982a, Measurement and computation of streamflow-Volume 1, Measurement of stage and discharge: U.S. Geological Survey Water-Supply Paper 2175,313 p.

Rantz, S.E., and others, 1982b, Measurement and computation of streamflow_-Volume 2, Computation of discharge: U.S. Geological Survey Water-Supply Paper 2175, 373 p.

Runkel, R.L., Crawford, C.G., and Cohn, T.A., 2004, Load estimator (LOADEST) - A FORTRAN program for estimating constituent loads in streams and rivers: U.S. Geological Survey Techniques and Methods, book 4, chap. A5, 69 p.

Sanford, W.E., and Selnick, D.L., 2013, Estimation of evapotranspiration across the conterminous United States using a regression with climate and land-cover data: Journal of the American Resources Association, v. 49, no. 1, p. 217-230.

Semkin, R.G., Jefferies, D.S., and Clair, T.A., 1994, Hydrochemical methods and relationships for study of stream output from small catchments, in Moldan, B., and Cerny, J., eds. Biogeochemistry of small catchments - A tool for environmental research: New York, John Wiley and Sons, p. $163-187$.

Sloto, R.A., and Crouse, M.Y., 1996, HYSEP —A computer program for streamflow hydrograph separation and analysis: U.S. Geological Survey Water-Resources Investigations Report 96-4040, 46 p.

U.S. Census Bureau, 2004, U.S. Census Bureau Web site accessed December 2004, at http://www.census.gov.

U.S. Census Bureau, 2011, Population of Gwinnett County, Georgia, accessed October 20, 2011, at http://quickfacts. census.gov/qfd/states/13/13135.html.

U.S. Census Bureau, 2012, American community survey 5-year estimates of 2006-2010 block group data, accessed January 26, 2014, at http://www.census.gov/geo/maps-data/ data/tiger-data.html.

U.S. Drought Monitor, 2014a, U.S. drought monitor map archive, accessed April 28, 2014, at http://droughtmonitor. unl.edu/MapsAndData/MapArchive.aspx.
U.S. Drought Monitor, 2014b, U.S. drought monitor classification scheme, drought severity classification, accessed April 28, 2014, at http://droughtmonitor.unl.edu/AboutUs/ ClassificationScheme.aspx.

U.S. Environmental Protection Agency, 2000a, Criteria development guidance-Rivers and streams-Nutrient Criteria Technical Guidance Manual-Rivers and Streams: U.S. Environmental Protection Agency EPA-822-B-00-002, accessed June 21, 2012, at http://water.epa.gov/scitech/ swguidance/standards/criteria/nutrients/rivers/index.cfm.

U.S. Environmental Protection Agency, 2000b, Overview of current total maximum daily load-TMDL_program and regulations: U.S. Environmental Protection Agency, EPA 841-F-00-009, 4 p.

U.S. Environmental Protection Agency, 2010, Georgia water quality assessment report, Georgia cumulative TMDLs by pollutant, accessed August 2011, at http://ofmpub.epa.gov/ tmdl_waters10/attains_state.control?p_state $=G A$.

U.S. Environmental Protection Agency, 2011, Secondary Drinking Water Regulations - Guidance for nuisance chemicals: U.S. Environmental Protection Agency 816-F-10-079, accessed October 26, 2011, at http://water. epa.gov/drink/contaminants/secondarystandards.cfm.

U.S. Geological Survey, 2006, Collection of water samples (ver. 2.0): U.S. Geological Survey Techniques of WaterResources Investigations, book 9, chap. A4, September 2006, accessed July 21, 2014, at http://pubs.water.usgs.gov/ twri9A4/.

U.S. Geological Survey, 2014, Geologic units in Gwinnett County, Georgia: U.S. Geological Survey mineral resources online spatial data, accessed May 16, 2014, at http://mrdata. usgs.gov/geology/state/fips-unit.php? code $=f 13135$.

U.S. Geological Survey, variously dated, National field manual for the collection of water-quality data: U.S. Geological Survey Techniques of Water-Resources Investigations, book 9, chaps. A1-A9, accessed July 21, 2014, at http://pubs.water.usgs.gov/twri9A/.

Wagner, R.J., Boulger, R.W., Jr., Oblinger, C.J., and Smith, B.A., 2006, Guidelines and standard procedures for continuous water-quality monitors-Station operation, record computation, and data reporting: U.S. Geological Survey Techniques and Methods 1-D3, 51 p., 8 attachments. 



\section{Appendix}

Statistical summaries of the water-quality sample concentrations for 13 field and laboratory constituents (table 2) are provided by watershed in tables 1-1 through 1-12.

1-1. Yellow River at Georgia 124 near Lithonia, Georgia, station number 02207120

1-2. No Business Creek at Lee Road, below Snellville, Georgia, station number 02207185

1-3. Big Haynes Creek at Lenora Road, near Loganville, Georgia, station number 02207385

1-4. Brushy Fork Creek at Beaver Road, near Loganville, Georgia, station number 02207400

1-5. Alcovy River at New Hope Road, near Grayson, Georgia, station number 02208150

1-6. Wheeler Creek at Bill Cheek Road, near Auburn, Georgia, station number 02217274

1-7. Apalachee River at Fence Road, near Dacula, Georgia, station number 02218565

1-8. Richland Creek at Suwanee Dam Road, near Buford, Georgia, station number 02334480

1-9. Level Creek at Suwanee Dam Road, near Suwanee, Georgia, station number 02334578

1-10. Suwanee Creek at Suwanee, Georgia, station number 02334885

1-11. Crooked Creek near Norcross, Georgia, station number 02335350

1-12. North Fork Peachtree Creek at Graves Road, near Doraville, Georgia, station number 02336030 
Table 1-1. Statistical summary for selected constituents, Yellow River at Georgia 124 near Lithonia, Georgia, station number 02207120. Samples collected 1996-2009.

$[\mu \mathrm{S} / \mathrm{cm}$, microsiemens per centimeter; FNU, formazin nephelometric unit; $\mathrm{mg} / \mathrm{L}$, milligrams per liter; $\%$, percentile percentage of samples that are less than listed concentrations for each station]

\begin{tabular}{|c|c|c|c|c|c|c|c|c|c|c|}
\hline \multirow{2}{*}{ Constituent } & \multicolumn{2}{|c|}{$\begin{array}{c}\text { Number and } \\
\text { type of samples }\end{array}$} & \multicolumn{8}{|c|}{ Concentration } \\
\hline & $\begin{array}{l}\text { Base } \\
\text { flow }\end{array}$ & $\begin{array}{l}\text { Storm- } \\
\text { flow }\end{array}$ & Mean & Maximum & Minimum & $10 \%$ & $25 \%$ & $50 \%$ & $75 \%$ & $90 \%$ \\
\hline Specific conductance $(\mu \mathrm{S} / \mathrm{cm})$ & 68 & 90 & 162 & 2,900 & 39 & 69 & 104 & 140 & 172 & 233 \\
\hline Turbidity (FNU) & 68 & 89 & 102 & 1,002 & 0.5 & 4.0 & 7 & 31 & 138 & 290 \\
\hline $\begin{array}{l}\text { Ammonia plus organic nitrogen } \\
(\mathrm{mg} / \mathrm{L} \text { as } \mathrm{N})\end{array}$ & 65 & 69 & 0.71 & 3.60 & 0.11 & 0.23 & 0.30 & 0.50 & 0.92 & 1.50 \\
\hline Nitrogen, total (mg/L as N) & 69 & 77 & 2.36 & 6.40 & 0.22 & 1.37 & 1.81 & 2.18 & 2.76 & 3.60 \\
\hline Phosphorus, total (mg/L as $\mathrm{P}$ ) & 69 & 76 & 0.079 & 0.640 & 0.006 & 0.013 & 0.020 & 0.032 & 0.090 & 0.200 \\
\hline Zinc, total $(\mu \mathrm{g} / \mathrm{L})$ & 69 & 77 & 30 & 200 & 4.8 & 7.8 & 10 & 18 & 38 & 70 \\
\hline Dissolved solids, total (mg/L) & 69 & 77 & 95 & 230 & 44 & 54 & 73 & 94 & 111 & 140 \\
\hline Suspended solids, total (mg/L) & 68 & 77 & 126 & 1,300 & 1 & 2 & 4 & 29 & 170 & 346 \\
\hline Suspended sediment (mg/L) & 15 & 45 & 206 & 988 & 2 & 7 & 32 & 134 & 288 & 537 \\
\hline
\end{tabular}

Table 1-2. Statistical summary for selected constituents, No Business Creek at Lee Road, below Snellville, Georgia, station number 02207185. Samples collected 2001-2009.

$[\mu \mathrm{S} / \mathrm{cm}$, microsiemens per centimeter; FNU, formazin nephelometric unit; $\mathrm{mg} / \mathrm{L}$, milligrams per liter; \%, percentile percentage of samples that are less than listed concentrations for each station]

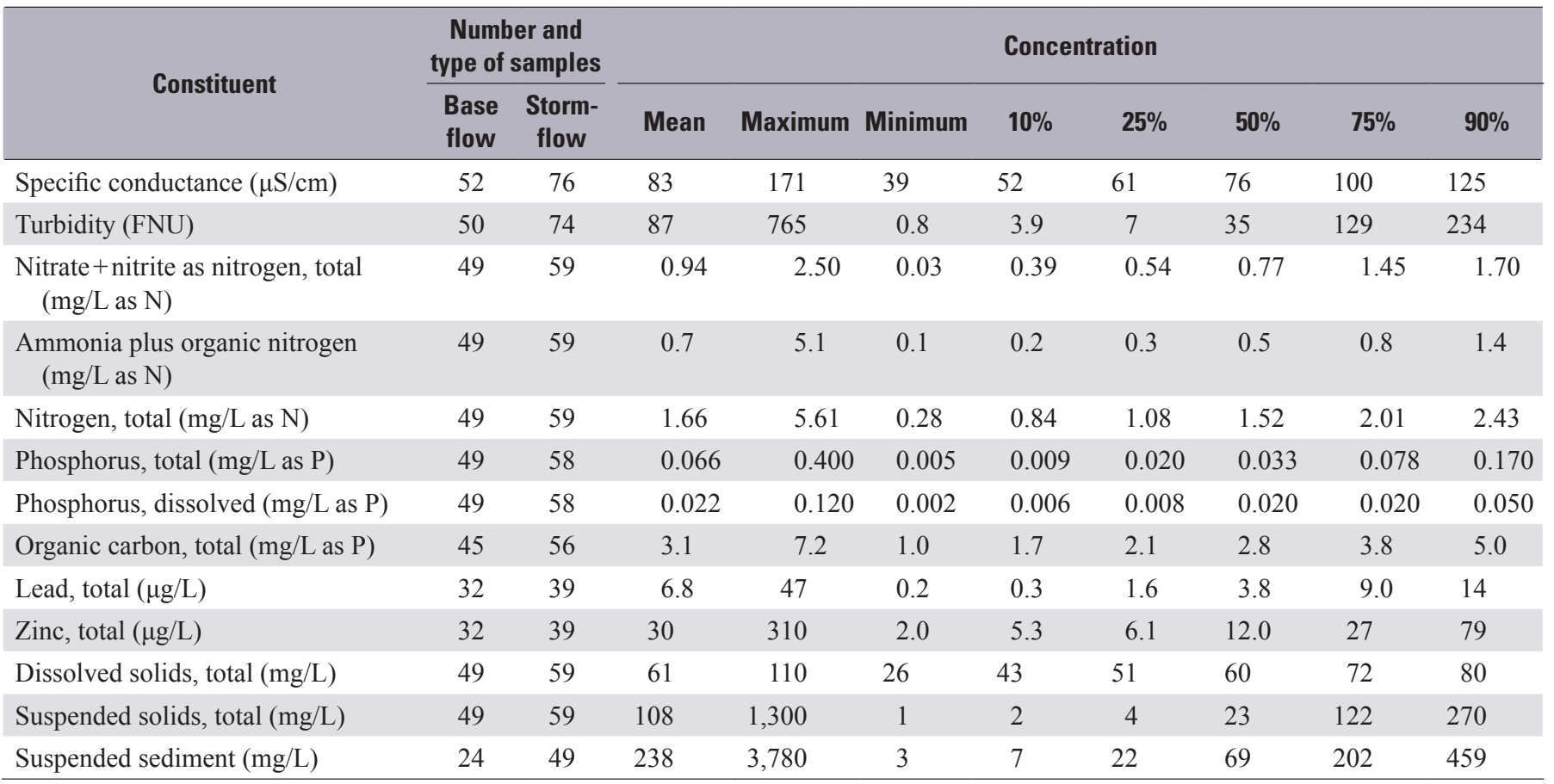


Table 1-3. Statistical summary for selected constituents, Big Haynes Creek at Lenora Road, near Loganville, Georgia, station number 02207385. Samples collected 1996-2009.

$[\mu \mathrm{S} / \mathrm{cm}$, microsiemens per centimeter; FNU, formazin nephelometric unit; $\mathrm{mg} / \mathrm{L}$, milligrams per liter; \%, percentile percentage of samples that are less than listed concentrations for each station]

\begin{tabular}{|c|c|c|c|c|c|c|c|c|c|c|}
\hline \multirow{2}{*}{ Constituent } & \multicolumn{2}{|c|}{$\begin{array}{c}\text { Number and } \\
\text { type of samples }\end{array}$} & \multicolumn{8}{|c|}{ Concentration } \\
\hline & $\begin{array}{l}\text { Base } \\
\text { flow }\end{array}$ & $\begin{array}{l}\text { Storm- } \\
\text { flow }\end{array}$ & Mean & Maximum & Minimum & $10 \%$ & $25 \%$ & $50 \%$ & $75 \%$ & $90 \%$ \\
\hline Specific conductance $(\mu \mathrm{S} / \mathrm{cm})$ & 106 & 91 & 59 & 160 & 20 & 42 & 50 & 59 & 65 & 75 \\
\hline Turbidity (FNU) & 106 & 91 & 100 & 1,105 & 0.8 & 5.0 & 7.2 & 19.6 & 104 & 265 \\
\hline $\begin{array}{l}\text { Ammonia plus organic nitrogen } \\
(\mathrm{mg} / \mathrm{L} \text { as } \mathrm{N})\end{array}$ & 88 & 79 & 0.7 & 2.6 & 0.1 & 0.2 & 0.3 & 0.4 & 0.9 & 1.6 \\
\hline Nitrogen, total (mg/L as N) & 88 & 79 & 1.50 & 3.37 & 0.80 & 1.00 & 1.12 & 1.34 & 1.72 & 2.40 \\
\hline Phosphorus, total (mg/L as P) & 88 & 78 & 0.110 & 0.590 & 0.006 & 0.016 & 0.033 & 0.074 & 0.150 & 0.280 \\
\hline Phosphorus, dissolved (mg/L as P) & 88 & 83 & 0.039 & 0.340 & 0.000 & 0.007 & 0.014 & 0.020 & 0.050 & 0.093 \\
\hline Zinc, total $(\mu \mathrm{g} / \mathrm{L})$ & 87 & 79 & 25 & 580 & 2.0 & 4.4 & 6.3 & 12 & 31 & 55 \\
\hline Dissolved solids, total (mg/L) & 88 & 79 & 57 & 1,400 & 20 & 34 & 40 & 49 & 56 & 62 \\
\hline Suspended solids, total (mg/L) & 87 & 79 & 128 & 1,100 & 1 & 3 & 5 & 14 & 180 & 390 \\
\hline Suspended sediment (mg/L) & 17 & 46 & 758 & 10,500 & 4 & 6 & 25 & 199 & 457 & 1,038 \\
\hline
\end{tabular}

Table 1-4. Statistical summary for selected constituents, Brushy Fork Creek at Beaver Road, near Loganville, Georgia, station number 02207400. Samples collected 1996-2009.

$[\mu \mathrm{S} / \mathrm{cm}$, microsiemens per centimeter; FNU, formazin nephelometric unit; $\mathrm{mg} / \mathrm{L}$, milligrams per liter; \%, percentile percentage of samples that are less than listed concentrations for each station]

\begin{tabular}{|c|c|c|c|c|c|c|c|c|c|c|}
\hline \multirow{2}{*}{ Constituent } & \multicolumn{2}{|c|}{$\begin{array}{c}\text { Number and } \\
\text { type of samples }\end{array}$} & \multicolumn{8}{|c|}{ Concentration } \\
\hline & $\begin{array}{l}\text { Base } \\
\text { flow }\end{array}$ & $\begin{array}{l}\text { Storm- } \\
\text { flow }\end{array}$ & Mean & Maximum & Minimum & $10 \%$ & $25 \%$ & $50 \%$ & $75 \%$ & $90 \%$ \\
\hline Specific conductance $(\mu \mathrm{S} / \mathrm{cm})$ & 89 & 91 & 43 & 95 & 10 & 34 & 39 & 44 & 47 & 50 \\
\hline Turbidity (FNU) & 88 & 91 & 113 & 2,062 & 3 & 9 & 14 & 31 & 131 & 282 \\
\hline $\begin{array}{l}\text { Nitrate }+ \text { nitrite as nitrogen, total } \\
\quad(\mathrm{mg} / \mathrm{L} \text { as } \mathrm{N})\end{array}$ & 89 & 75 & 0.30 & 1.40 & 0.02 & 0.17 & 0.22 & 0.28 & 0.35 & 0.46 \\
\hline $\begin{array}{l}\text { Ammonia plus organic nitrogen } \\
\quad(\mathrm{mg} / \mathrm{L} \text { as } \mathrm{N})\end{array}$ & 89 & 75 & 0.8 & 4.9 & 0.1 & 0.3 & 0.3 & 0.5 & 0.9 & 1.6 \\
\hline Nitrogen, total (mg/L as $\mathrm{N})$ & 89 & 75 & 1.07 & 5.16 & 0.26 & 0.51 & 0.61 & 0.79 & 1.27 & 2.09 \\
\hline Phosphorus, total (mg/L as $\mathrm{P}$ ) & 89 & 75 & 0.106 & 1.400 & 0.005 & 0.020 & 0.030 & 0.050 & 0.125 & 0.250 \\
\hline Phosphorus, dissolved (mg/L as P) & 89 & 75 & 0.024 & 0.120 & 0.003 & 0.015 & 0.020 & 0.020 & 0.020 & 0.038 \\
\hline Dissolved solids, total (mg/L) & 89 & 76 & 43 & 300 & 20 & 30 & 34 & 40 & 46 & 55 \\
\hline Suspended solids, total $(\mathrm{mg} / \mathrm{L})$ & 88 & 75 & 158 & 3,300 & 1 & 5 & 8 & 19 & 197 & 390 \\
\hline Suspended sediment $(\mathrm{mg} / \mathrm{L})$ & 16 & 46 & 364 & 3,817 & 5 & 11 & 28 & 156 & 358 & 948 \\
\hline
\end{tabular}


Table 1-5. Statistical summary for selected constituents, Alcovy River at New Hope Road, near Grayson, Georgia, station number 02208150. Samples collected 1997-2009.

$[\mu \mathrm{S} / \mathrm{cm}$, microsiemens per centimeter; FNU, formazin nephelometric unit; $\mathrm{mg} / \mathrm{L}$, milligrams per liter; \%, percentile percentage of samples that are less than listed concentrations for each station]

\begin{tabular}{|c|c|c|c|c|c|c|c|c|c|c|}
\hline \multirow{2}{*}{ Constituent } & \multicolumn{2}{|c|}{$\begin{array}{c}\text { Number and } \\
\text { type of samples }\end{array}$} & \multicolumn{8}{|c|}{ Concentration } \\
\hline & $\begin{array}{l}\text { Base } \\
\text { flow }\end{array}$ & $\begin{array}{l}\text { Storm- } \\
\text { flow }\end{array}$ & Mean & Maximum & Minimum & $10 \%$ & $25 \%$ & $50 \%$ & $75 \%$ & $90 \%$ \\
\hline Specific conductance $(\mu \mathrm{S} / \mathrm{cm})$ & 70 & 81 & 72 & 202 & 35 & 52 & 58 & 72 & 82 & 89 \\
\hline Turbidity (FNU) & 68 & 82 & 174 & 3,036 & 2 & 6 & 10 & 39 & 232 & 450 \\
\hline $\begin{array}{l}\text { Nitrate }+ \text { nitrite as nitrogen, total } \\
\quad(\mathrm{mg} / \mathrm{L} \text { as } \mathrm{N})\end{array}$ & 68 & 74 & 0.44 & 0.88 & 0.18 & 0.28 & 0.37 & 0.43 & 0.51 & 0.56 \\
\hline $\begin{array}{l}\text { Ammonia plus organic nitrogen } \\
(\mathrm{mg} / \mathrm{L} \text { as } \mathrm{N})\end{array}$ & 70 & 74 & 0.8 & 4.7 & 0.1 & 0.2 & 0.21 & 0.5 & 1.0 & 1.4 \\
\hline Nitrogen, total (mg/L as $\mathrm{N})$ & 70 & 74 & 1.18 & 5.15 & 0.38 & 0.61 & 0.70 & 0.95 & 1.46 & 1.89 \\
\hline Phosphorus, total (mg/L as $\mathrm{P})$ & 70 & 73 & 0.105 & 0.800 & 0.004 & 0.008 & 0.020 & 0.050 & 0.160 & 0.270 \\
\hline Phosphorus, dissolved (mg/L as $\mathrm{P}$ ) & 70 & 82 & 0.021 & 0.027 & 0.002 & 0.003 & 0.007 & 0.020 & 0.020 & 0.050 \\
\hline Dissolved solids, total (mg/L) & 68 & 74 & 58 & 220 & 18 & 40 & 47 & 54 & 63 & 76 \\
\hline Suspended solids, total (mg/L) & 67 & 73 & 224 & 1,600 & 1 & 3 & 5 & 39 & 355 & 705 \\
\hline Suspended sediment (mg/L) & 19 & 40 & 467 & 2,247 & 5 & 7 & 18 & 306 & 724 & 1,259 \\
\hline
\end{tabular}

Table 1-6. Statistical summary for selected constituents, Wheeler Creek at Bill Cheek Road, near Auburn, Georgia, station number 02217274. Samples collected 2001-2009.

$[\mu \mathrm{S} / \mathrm{cm}$, microsiemens per centimeter; FNU, formazin nephelometric unit; $\mathrm{mg} / \mathrm{L}$, milligrams per liter; \%, percentile percentage of samples that are less than listed concentrations for each station]

\begin{tabular}{|c|c|c|c|c|c|c|c|c|c|c|}
\hline \multirow{2}{*}{ Constituent } & \multicolumn{2}{|c|}{$\begin{array}{c}\text { Number and } \\
\text { type of samples }\end{array}$} & \multicolumn{8}{|c|}{ Concentration } \\
\hline & $\begin{array}{l}\text { Base } \\
\text { flow }\end{array}$ & $\begin{array}{l}\text { Storm- } \\
\text { flow }\end{array}$ & Mean & Maximum & Minimum & $10 \%$ & $25 \%$ & $50 \%$ & $75 \%$ & $90 \%$ \\
\hline Specific conductance $(\mu \mathrm{S} / \mathrm{cm})$ & 50 & 65 & 50 & 190 & 20 & 36 & 42 & 49 & 55 & 60 \\
\hline Turbidity (FNU) & 51 & 71 & 196 & 2,043 & 2 & 4 & 9 & 48 & 182 & 451 \\
\hline $\begin{array}{l}\text { Nitrate }+ \text { nitrite as nitrogen, total } \\
\quad(\mathrm{mg} / \mathrm{L} \text { as } \mathrm{N})\end{array}$ & 50 & 58 & 0.59 & 0.93 & 0.10 & 0.33 & 0.39 & 0.60 & 0.78 & 0.86 \\
\hline $\begin{array}{l}\text { Ammonia plus organic nitrogen } \\
(\mathrm{mg} / \mathrm{L} \text { as } \mathrm{N})\end{array}$ & 50 & 58 & 0.8 & 3.3 & 0.1 & 0.2 & 0.3 & 0.5 & 1.1 & 1.8 \\
\hline Nitrogen, total (mg/L as $\mathrm{N})$ & 50 & 58 & 1.39 & 3.92 & 0.51 & 0.88 & 1.00 & 1.19 & 1.53 & 2.28 \\
\hline Phosphorus, total (mg/L as $\mathrm{P})$ & 50 & 57 & 0.111 & 0.650 & 0.004 & 0.012 & 0.020 & 0.050 & 0.170 & 0.280 \\
\hline Phosphorus, dissolved (mg/L as P) & 50 & 58 & 0.032 & 0.150 & 0.000 & 0.007 & 0.020 & 0.020 & 0.050 & 0.067 \\
\hline Dissolved solids, total (mg/L) & 50 & 58 & 52 & 220 & 8 & 32 & 38 & 45 & 54 & 68 \\
\hline Suspended solids, total (mg/L) & 50 & 58 & 256 & 5,400 & 1 & 2 & 4 & 46 & 218 & 611 \\
\hline Suspended sediment $(\mathrm{mg} / \mathrm{L})$ & 23 & 48 & 430 & 4,060 & 1 & 4 & 25 & 127 & 592 & 1,094 \\
\hline
\end{tabular}


Table 1-7. Statistical summary for selected constituents, Apalachee River at Fence Road, near Dacula, Georgia, station number 02218565. Samples collected 2001-2009.

$[\mu \mathrm{S} / \mathrm{cm}$, microsiemens per centimeter; FNU, formazin nephelometric unit; $\mathrm{mg} / \mathrm{L}$, milligrams per liter; \%, percentile percentage of samples that are less than listed concentrations for each station]

\begin{tabular}{|c|c|c|c|c|c|c|c|c|c|c|}
\hline \multirow{2}{*}{ Constituent } & \multicolumn{2}{|c|}{$\begin{array}{c}\text { Number and } \\
\text { type of samples }\end{array}$} & \multicolumn{8}{|c|}{ Concentration } \\
\hline & $\begin{array}{l}\text { Base } \\
\text { flow }\end{array}$ & $\begin{array}{l}\text { Storm- } \\
\text { flow }\end{array}$ & Mean & Maximum & Minimum & $10 \%$ & $25 \%$ & $50 \%$ & $75 \%$ & $90 \%$ \\
\hline Specific conductance $(\mu \mathrm{S} / \mathrm{cm})$ & 49 & 67 & 56 & 140 & 20 & 40 & 47 & 57 & 63 & 71 \\
\hline Turbidity (FNU) & 48 & 68 & 171 & 1,180 & 3.7 & 5.1 & 8 & 73 & 293 & 497 \\
\hline $\begin{array}{l}\text { Nitrate }+ \text { nitrite as nitrogen, total } \\
\quad(\mathrm{mg} / \mathrm{L} \text { as } \mathrm{N})\end{array}$ & 47 & 53 & 0.44 & 0.78 & 0.13 & 0.28 & 0.34 & 0.43 & 0.51 & 0.62 \\
\hline $\begin{array}{l}\text { Ammonia plus organic nitrogen } \\
(\mathrm{mg} / \mathrm{L} \text { as } \mathrm{N})\end{array}$ & 28 & 65 & 0.90 & 3.40 & 0.08 & 0.20 & 0.26 & 0.50 & 1.25 & 2.30 \\
\hline Nitrogen, total (mg/L as N) & 47 & 53 & 1.39 & 4.20 & 0.42 & 0.56 & 0.68 & 0.92 & 1.94 & 3.00 \\
\hline Phosphorus, total (mg/L as P) & 47 & 53 & 0.102 & 0.500 & 0.003 & 0.010 & 0.020 & 0.050 & 0.140 & 0.280 \\
\hline Phosphorus, dissolved (mg/L as P) & 47 & 53 & 0.021 & 0.078 & 0.003 & 0.005 & 0.010 & 0.020 & 0.020 & 0.050 \\
\hline Dissolved solids, total (mg/L) & 47 & 53 & 50 & 140 & 18 & 32 & 42 & 47 & 55 & 70 \\
\hline Suspended solids, total (mg/L) & 47 & 53 & 274 & 2,000 & 1 & 3 & 4 & 52 & 380 & 815 \\
\hline Suspended sediment (mg/L) & 23 & 46 & 544 & 3,992 & 1 & 6 & 22 & 135 & 557 & 1,869 \\
\hline
\end{tabular}

Table 1-8. Statistical summary for selected constituents, Richland Creek at Suwanee Dam Road, near Buford, Georgia, station number 02334880. Samples collected 2001-2009.

$[\mu \mathrm{S} / \mathrm{cm}$, microsiemens per centimeter; FNU, formazin nephelometric unit; $\mathrm{mg} / \mathrm{L}$, milligrams per liter; \%, percentile percentage of samples that are less than listed concentrations for each station]

\begin{tabular}{|c|c|c|c|c|c|c|c|c|c|c|}
\hline \multirow{2}{*}{ Constituent } & \multicolumn{2}{|c|}{$\begin{array}{c}\text { Number and } \\
\text { type of samples }\end{array}$} & \multicolumn{8}{|c|}{ Concentration } \\
\hline & $\begin{array}{l}\text { Base } \\
\text { flow }\end{array}$ & $\begin{array}{l}\text { Storm- } \\
\text { flow }\end{array}$ & Mean & Maximum & Minimum & $10 \%$ & $25 \%$ & $50 \%$ & $75 \%$ & $90 \%$ \\
\hline Specific conductance $(\mu \mathrm{S} / \mathrm{cm})$ & 49 & 57 & 83 & 1,100 & 25 & 46 & 59 & 77 & 84 & 97 \\
\hline Turbidity (FNU) & 51 & 64 & 434 & 3,827 & 1.8 & 6.9 & 14 & 89 & 527 & 1,133 \\
\hline $\begin{array}{l}\text { Nitrate }+ \text { nitrite as nitrogen, total } \\
\quad(\mathrm{mg} / \mathrm{L} \text { as } \mathrm{N})\end{array}$ & 49 & 56 & 0.54 & 1.20 & 0.27 & 0.32 & 0.42 & 0.54 & 0.63 & 0.76 \\
\hline $\begin{array}{l}\text { Ammonia plus organic nitrogen } \\
(\mathrm{mg} / \mathrm{L} \text { as } \mathrm{N})\end{array}$ & 49 & 56 & 0.99 & 5.30 & 0.08 & 0.20 & 0.34 & 0.50 & 1.30 & 2.10 \\
\hline Nitrogen, total (mg/L as $\mathrm{N})$ & 49 & 56 & 1.54 & 5.77 & 0.50 & 0.80 & 0.91 & 1.16 & 1.87 & 2.59 \\
\hline Phosphorus, total (mg/L as $\mathrm{P})$ & 50 & 55 & 0.267 & 3.000 & 0.012 & 0.020 & 0.030 & 0.093 & 0.330 & 0.730 \\
\hline Phosphorus, dissolved (mg/L as $\mathrm{P}$ ) & 50 & 55 & 0.031 & 0.440 & 0.005 & 0.009 & 0.017 & 0.020 & 0.035 & 0.050 \\
\hline Organic carbon, total (mg/L as $\mathrm{P})$ & 48 & 53 & 3.0 & 12 & 0.4 & 1.1 & 1.4 & 2.4 & 4.1 & 5.9 \\
\hline Lead, total $(\mu \mathrm{g} / \mathrm{L})$ & 31 & 40 & 18 & 89 & 0.1 & 0.5 & 3 & 9 & 24 & 48 \\
\hline Zinc, total $(\mu \mathrm{g} / \mathrm{L})$ & 31 & 40 & 76 & 780 & 2 & 5 & 7 & 30 & 88 & 220 \\
\hline Dissolved solids, total (mg/L) & 50 & 57 & 71 & 300 & 19 & 43 & 51 & 58 & 73 & 100 \\
\hline Suspended solids, total (mg/L) & 50 & 56 & 592 & 6,900 & 1 & 3 & 10 & 150 & 640 & 1,530 \\
\hline Suspended sediment (mg/L) & 25 & 50 & 1,234 & 9,301 & 3 & 20 & 37 & 380 & 1,636 & 3,326 \\
\hline
\end{tabular}


Table 1-9. Statistical summary for selected constituents, Level Creek at Suwanee Dam Road, near Suwanee, Georgia, station number 02334578. Samples collected 2001-2009.

$[\mu \mathrm{S} / \mathrm{cm}$, microsiemens per centimeter; FNU, formazin nephelometric unit; $\mathrm{mg} / \mathrm{L}$, milligrams per liter; \%, percentile percentage of samples that are less than listed concentrations for each station]

\begin{tabular}{|c|c|c|c|c|c|c|c|c|c|c|}
\hline \multirow{2}{*}{ Constituent } & \multicolumn{2}{|c|}{$\begin{array}{c}\text { Number and } \\
\text { type of samples }\end{array}$} & \multicolumn{8}{|c|}{ Concentration } \\
\hline & $\begin{array}{l}\text { Base } \\
\text { flow }\end{array}$ & $\begin{array}{l}\text { Storm- } \\
\text { flow }\end{array}$ & Mean & Maximum & Minimum & $10 \%$ & $25 \%$ & $50 \%$ & $75 \%$ & $90 \%$ \\
\hline Specific conductance $(\mu \mathrm{S} / \mathrm{cm})$ & 48 & 75 & 99 & 3,600 & 26 & 37 & 50 & 64 & 77 & 82 \\
\hline Turbidity (FNU) & 48 & 75 & 235 & 2,570 & 2.3 & 4.2 & 7.1 & 78 & 328 & 602 \\
\hline $\begin{array}{l}\text { Nitrate }+ \text { nitrite as nitrogen, total } \\
\quad(\mathrm{mg} / \mathrm{L} \text { as } \mathrm{N})\end{array}$ & 48 & 58 & 0.36 & 1.30 & 0.02 & 0.17 & 0.27 & 0.34 & 0.43 & 0.55 \\
\hline $\begin{array}{l}\text { Ammonia plus organic nitrogen } \\
(\mathrm{mg} / \mathrm{L} \text { as } \mathrm{N})\end{array}$ & 48 & 53 & 0.86 & 3.80 & 0.15 & 0.20 & 0.28 & 0.51 & 1.10 & 2.20 \\
\hline Nitrogen, total (mg/L as $\mathrm{N})$ & 48 & 58 & 1.28 & 4.90 & 0.22 & 0.46 & 0.64 & 0.91 & 1.69 & 2.90 \\
\hline Phosphorus, total (mg/L as $\mathrm{P})$ & 48 & 57 & 0.140 & 1.000 & 0.004 & 0.014 & 0.020 & 0.050 & 0.210 & 0.430 \\
\hline Phosphorus, dissolved (mg/L as $\mathrm{P}$ ) & 48 & 57 & 0.027 & 0.110 & 0.004 & 0.008 & 0.016 & 0.020 & 0.039 & 0.050 \\
\hline Dissolved solids, total (mg/L) & 48 & 58 & 57 & 120 & 25 & 39 & 48 & 55 & 63 & 72 \\
\hline Suspended solids, total (mg/L) & 48 & 58 & 271 & 2,500 & 1 & 3 & 4 & 67 & 320 & 1,000 \\
\hline Suspended sediment (mg/L) & 24 & 49 & 538 & 5,121 & 2 & 5 & 23 & 165 & 674 & 1,678 \\
\hline
\end{tabular}

Table 1-10. Statistical summary for selected constituents, Suwanee Creek at Suwanee, Georgia, station number 02334885. Samples collected 1996-2009.

$[\mu \mathrm{S} / \mathrm{cm}$, microsiemens per centimeter; FNU, formazin nephelometric unit; $\mathrm{mg} / \mathrm{L}$, milligrams per liter; \%, percentile percentage of samples that are less than listed concentrations for each station]

\begin{tabular}{|c|c|c|c|c|c|c|c|c|c|c|}
\hline \multirow{2}{*}{ Constituent } & \multicolumn{2}{|c|}{$\begin{array}{c}\begin{array}{c}\text { Number and } \\
\text { type of samples }\end{array} \\
\end{array}$} & \multicolumn{8}{|c|}{ Concentration } \\
\hline & $\begin{array}{l}\text { Base } \\
\text { flow }\end{array}$ & $\begin{array}{l}\text { Storm- } \\
\text { flow }\end{array}$ & Mean & Maximum & Minimum & $10 \%$ & $25 \%$ & $50 \%$ & $75 \%$ & $90 \%$ \\
\hline Specific conductance $(\mu \mathrm{S} / \mathrm{cm})$ & 99 & 102 & 116 & 3,700 & 34 & 60 & 74 & 97 & 110 & 140 \\
\hline Turbidity (FNU) & 94 & 100 & 134 & 1213 & 2.7 & 5.9 & 13 & 30 & 205 & 390 \\
\hline $\begin{array}{l}\text { Nitrate }+ \text { nitrite as nitrogen, total } \\
\quad(\mathrm{mg} / \mathrm{L} \text { as } \mathrm{N})\end{array}$ & 86 & 85 & 0.75 & 4.20 & 0.10 & 0.39 & 0.50 & 0.66 & 0.88 & 1.10 \\
\hline $\begin{array}{l}\text { Ammonia plus organic nitrogen } \\
(\mathrm{mg} / \mathrm{L} \text { as } \mathrm{N})\end{array}$ & 71 & 71 & 0.67 & 2.30 & 0.14 & 0.20 & 0.29 & 0.50 & 1.00 & 1.40 \\
\hline Nitrogen, total (mg/L as N) & 72 & 84 & 1.44 & 4.80 & 0.49 & 0.86 & 1.03 & 1.28 & 1.73 & 2.24 \\
\hline Phosphorus, total (mg/L as P) & 85 & 84 & 0.114 & 0.790 & 0.004 & 0.015 & 0.020 & 0.040 & 0.140 & 0.310 \\
\hline Phosphorus, dissolved (mg/L as P) & 86 & 85 & 0.023 & 0.310 & 0.002 & 0.008 & 0.014 & 0.020 & 0.020 & 0.043 \\
\hline Dissolved solids, total (mg/L) & 68 & 85 & 67 & 140 & 25 & 44 & 55 & 66 & 78 & 90 \\
\hline Suspended solids, total (mg/L) & 79 & 85 & 130 & 870 & 1 & 4 & 8 & 30 & 192 & 410 \\
\hline Suspended sediment (mg/L) & 22 & 53 & 232 & 1,739 & 2 & 10 & 22 & 150 & 302 & 545 \\
\hline
\end{tabular}


Table 1-11. Statistical summary for selected constituents, Crooked Creek near Norcross, Georgia, station number 02335350. Samples collected 1996-2009.

$[\mu \mathrm{S} / \mathrm{cm}$, microsiemens per centimeter; FNU, formazin nephelometric unit; $\mathrm{mg} / \mathrm{L}$, milligrams per liter; \%, percentile percentage of samples that are less than listed concentrations for each station]

\begin{tabular}{|c|c|c|c|c|c|c|c|c|c|c|}
\hline \multirow{2}{*}{ Constituent } & \multicolumn{2}{|c|}{$\begin{array}{l}\text { Number and } \\
\text { type of samples }\end{array}$} & \multicolumn{8}{|c|}{ Concentration } \\
\hline & $\begin{array}{l}\text { Base } \\
\text { flow }\end{array}$ & $\begin{array}{l}\text { Storm- } \\
\text { flow }\end{array}$ & Mean & Maximum & Minimum & $10 \%$ & $25 \%$ & $50 \%$ & $75 \%$ & $90 \%$ \\
\hline Specific conductance $(\mu \mathrm{S} / \mathrm{cm})$ & 81 & 98 & 116 & 4,500 & 28 & 43 & 57 & 89 & 103 & 110 \\
\hline Turbidity (FNU) & 78 & 95 & 151 & 2,439 & 2.3 & 3.9 & 6.4 & 38 & 200 & 428 \\
\hline $\begin{array}{l}\text { Ammonia plus organic nitrogen } \\
(\mathrm{mg} / \mathrm{L} \text { as } \mathrm{N})\end{array}$ & 67 & 69 & 0.82 & 3.80 & 0.13 & 0.20 & 0.26 & 0.52 & 1.25 & 1.80 \\
\hline Nitrogen, total (mg/L as N) & 70 & 82 & 1.21 & 4.14 & 0.25 & 0.48 & 0.61 & 0.92 & 1.68 & 2.25 \\
\hline Phosphorus, total (mg/L as $\mathrm{P}$ ) & 82 & 81 & 0.125 & 0.820 & 0.006 & 0.016 & 0.020 & 0.037 & 0.195 & 0.380 \\
\hline Phosphorus, dissolved (mg/L as P) & 83 & 81 & 0.023 & 0.280 & 0.002 & 0.008 & 0.016 & 0.020 & 0.020 & 0.040 \\
\hline Zinc, total $(\mu \mathrm{g} / \mathrm{L})$ & 71 & 82 & 66 & 710 & 4 & 6 & 10 & 39 & 97 & 160 \\
\hline Dissolved solids, total (mg/L) & 71 & 82 & 60 & 170 & 14 & 36 & 44 & 60 & 70 & 78 \\
\hline Suspended solids, total (mg/L) & 81 & 82 & 270 & 3,120 & 1 & 2 & 4 & 41 & 370 & 700 \\
\hline Suspended sediment (mg/L) & 17 & 41 & 687 & 3,141 & 2 & 4 & 16 & 362 & 1,241 & 1,686 \\
\hline
\end{tabular}

Table 1-12. Statistical summary for selected constituents, North Fork Peachtree Creek at Graves Road, near Doraville, Georgia, station number 02336030. Samples collected 2001-2009.

$[\mu \mathrm{S} / \mathrm{cm}$, microsiemens per centimeter; FNU, formazin nephelometric unit; $\mathrm{mg} / \mathrm{L}$, milligrams per liter; \%, percentile percentage of samples that are less than listed concentrations for each station]

\begin{tabular}{|c|c|c|c|c|c|c|c|c|c|c|}
\hline \multirow{2}{*}{ Constituent } & \multicolumn{2}{|c|}{$\begin{array}{c}\begin{array}{c}\text { Number and } \\
\text { type of samples }\end{array} \\
\end{array}$} & \multicolumn{8}{|c|}{ Concentration } \\
\hline & $\begin{array}{l}\text { Base } \\
\text { flow }\end{array}$ & $\begin{array}{l}\text { Storm- } \\
\text { flow }\end{array}$ & Mean & Maximum & Minimum & $10 \%$ & $25 \%$ & $50 \%$ & $75 \%$ & $90 \%$ \\
\hline Specific conductance $(\mu \mathrm{S} / \mathrm{cm})$ & 49 & 73 & 68 & 120 & 4 & 31 & 42 & 71 & 95 & 100 \\
\hline Turbidity (FNU) & 50 & 70 & 97 & 994 & 0.3 & 5 & 8 & 48 & 124 & 225 \\
\hline $\begin{array}{l}\text { Nitrate }+ \text { nitrite as nitrogen, total } \\
\quad(\mathrm{mg} / \mathrm{L} \text { as } \mathrm{N})\end{array}$ & 50 & 58 & 0.48 & 1.20 & 0.04 & 0.30 & 0.38 & 0.45 & 0.53 & 0.68 \\
\hline $\begin{array}{l}\text { Ammonia plus organic nitrogen } \\
\quad(\mathrm{mg} / \mathrm{L} \text { as } \mathrm{N})\end{array}$ & 50 & 58 & 0.8 & 4 & 0.1 & 0.2 & 0.3 & 0.5 & 1 & 1.6 \\
\hline Nitrogen, total (mg/L as N) & 50 & 58 & 125.00 & 4.86 & 0.44 & 0.61 & 0.72 & 0.94 & 1.50 & 2.28 \\
\hline Phosphorus, total (mg/L as P) & 50 & 57 & 0.097 & 0.680 & 0.004 & 0.010 & 0.020 & 0.050 & 0.140 & 0.200 \\
\hline Phosphorus, dissolved (mg/L as P) & 50 & 72 & 0.023 & 0.120 & 0.000 & 0.000 & 0.009 & 0.020 & 0.027 & 0.050 \\
\hline Dissolved solids, total (mg/L) & 50 & 58 & 58 & 170 & 10 & 32 & 44 & 62 & 71 & 81 \\
\hline Suspended solids, total (mg/L) & 50 & 58 & 123 & 870 & 1 & 2 & 4 & 28 & 180 & 350 \\
\hline Suspended sediment (mg/L) & 24 & 46 & 357 & 2,758 & 4 & 10 & 22 & 118 & 337 & 1,098 \\
\hline
\end{tabular}



Manuscript approved July 23, 2014

Prepared by the USGS Science Publishing Network Raleigh Publishing Service Center (PSC)

Edited by Kay P. Naugle

Illustrations by Kimberly A. Swidarski and Caryl J. Wipperfurth

Layout by Kay P. Naugle

Cover by Carol A. Quesenberry, Denver PSC

For more information concerning this report, contact: Director, Georgia Water Science Center

1770 Corporate Drive, Suite 500

Norcross, GA 30093

(678) 924-6700

http://ga.water.usgs.gov/ 


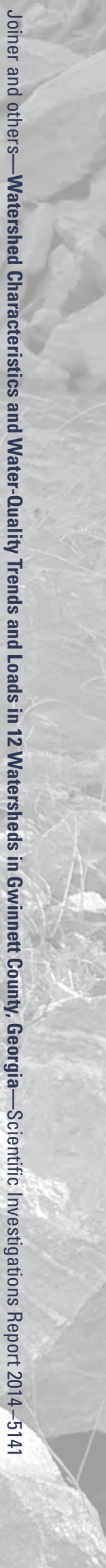

